FERNANDO FONTOURA DA SILVA CAIS

Direito processual civil intertemporal

DOUTORADO EM DIREITO

São Paulo

2.010 
FERNANDO FONTOURA DA SILVA CAIS

\section{Direito processual civil intertemporal}

Tese de doutorado apresentada ao Departamento de Direito Processual Civil da Faculdade de Direito da Universidade de São Paulo, como exigência parcial para obtenção do título de Doutor, sob a orientação do Professor Titular José Roberto dos Santos Bedaque.

São Paulo

2.010 
Banca examinadora

1.

2.

3.

4.

5. 
Para minha amada Gabriela. 
Agradeço profundamente ao meu orientador Professor Titular José Roberto dos Santos Bedaque pela oportunidade e confiança que me permitiram ingressar no curso de pósgraduação da Faculdade de Direito da Universidade de São Paulo. Sobretudo, agradeço pelos ensinamentos passados desde a graduação, sempre preocupados com o avanço da ciência processual para uma direção certa: a efetividade. Sou grato, ainda, por toda a orientação concedida no desenvolvimento deste trabalho;

agradeço a todos os Professores das Arcadas do Largo de São Francisco que contribuíram com minha formação, especialmente ao Professor Titular Cândido Rangel Dinamarco, modelo de Professor e de ser humano, com quem tive o privilégio de estagiar; ao Professor Doutor Carlos Alberto Carmona, pelos valiosos conselhos conferidos no exame de qualificação e pelo "treinamento" para o debate feito durante as aulas do curso de pósgraduação; também sou grato ao Professor Doutor José Carlos Baptista Puoli pela preciosa orientação dada no exame de qualificação e pela constante troca de idéias durante as aulas de seminário das disciplinas que cursei;

ao meu paizinho Homar, que é na verdade um grande pai, amigo e ponto de apoio para todas as horas, agradeço profundamente por todo $\mathrm{o}$ trabalho de revisão $\mathrm{e}$ aconselhamento;

à Gabriela, sou extremamente grato por todo apoio, incentivo, auxílio e paciência durante todos os anos que levei para concluir este estudo; 
ao meu irmão Frederico, agradeço pela troca de idéias, pelo constante apoio e por me substituir nas atividades de nosso escritório permitindo-me conferir a dedicação necessária para a elaboração desta tese;

sou grato à minha segunda mãe Cleide, que também prestou valoroso auxílio de revisão do trabalho;

devo meus agradecimentos aos meus irmãos, sobrinhos e demais familiares - com menção especial às minhas irmãs Ana Carolina e Maria Eugênia, às tias Zuleika e Rosinha e aos meus sogros Maria Cristina e Luiz Afonso - e a todos meus amigos, antigos e novos, presentes ou distantes, que sempre me apoiaram ao longo da vida;

agradeço, ainda, aos entes amados que partiram, especialmente minha mãe Sônia e minha avó Maria Antonietta, cujas presenças são constantemente sentidas;

por derradeiro, deixo o agradecimento mais especial a Deus, por tudo. 


\title{
Direito processual civil intertemporal
}

\author{
Capítulo I - Apresentação
}

1. Introdução

1.1. A tese.

1.2. Relevância e justificativa do estudo

1.3. Fixação de premissas

1.4. Da utilização do direito estrangeiro

Capítulo II - Apontamentos históricos do direito intertemporal

2.1. Noções preliminares

2.2. Evolução histórica do direito intertemporal

2.2.1. Fase "pré-científica"

2.2.1.1. Direito romano

2.2.1.2. Idade Média

2.2.1.3. Direito moderno

2.2.2. Fase "científica"

Capítulo III - Fundamentos do direito intertemporal

3.1. Considerações sobre o conceito de retroatividade na teoria clássica

3.2. O direito adquirido na teoria clássica

3.3. Direito adquirido na obra de GABBA

3.4. A doutrina de GABBA

3.5. O direito adquirido na doutrina pátria

3.6. A corrente objetivista

3.6.1. A importância de PAUL ROUBIER para o direito brasileiro

3.7. Principais aspectos da obra de ROUBIER

3.8. A retroatividade da lei na teoria de ROUBIER 
3.11. Pontos de contato entre as duas correntes

Capítulo IV - O direito intertemporal no ordenamento jurídico brasileiro

4.1. Os diversos sistemas de direito intertemporal

4.2. Evolução histórica do tratamento da matéria no ordenamento brasileiro

4.2.1. O direito intertemporal nas constituições brasileiras

4.2.2. A Lei de Introdução ao Código Civil e suas alterações

4.3. Perfil atual do direito intertemporal no ordenamento jurídico brasileiro

4.4. Direito adquirido, ato jurídico perfeito e coisa julgada

4.5. Limite de atuação do constituinte derivado

Capítulo V - Autonomia do direito processual civil intertemporal

5.1. Direito processual intertemporal

5.2. Análise das justificativas conferidas pela doutrina para o estudo autônomo do direito processual civil intertemporal

5.2.1. Direito processual e ordem pública

5.2.2. Complexidade da relação jurídica processual 96

5.2.3. Autonomia da relação jurídica processual

5.3. A relação jurídica como centro da autonomia do direito processual civil intertemporal: relação triangular e segurança jurídica 100

5.3.1. Análise dos fundamentos do direito intertemporal na teoria clássica 103

5.3.2. Fundamentos do direito intertemporal na teoria objetivista 106

5.3.3. A segurança jurídica no direito processual civil intertemporal 109

5.3.4. Fundamento da eficácia imediata da lei processual 115

5.4. Segurança jurídica, eficácia imediata da lei e a autonomia do direito processual civil intertemporal

Capítulo VI - Estágio atual do direito processual civil intertemporal

6.1. Objeto do estudo

6.1.1. Normas gerais de direito processual civil intertemporal 
6.1.2. Normas transitórias de direito processual civil intertemporal

$\begin{array}{lr}\text { 6.2. Doutrina } & 125\end{array}$

6.2.1. Os 'sistemas' de direito processual intertemporal 126

6.2.1.1. Ordenamento jurídico brasileiro e insuficiência dos grandes 'sistemas' de direito intertemporal

6.2.1.2. Razões teóricas para justificar o distanciamento da doutrina dos 'sistemas'

6.2.2. O posicionamento de GALENO LACERDA: um caminho a ser trilhado

6.2.3. Análise da doutrina de FÁBIO GUIDI TABOSA PESSOA

6.3. Jurisprudência

6.4. As lacunas da doutrina do direito processual civil intertemporal

Capítulo VII - Direitos processuais adquiridos

7.1. Roteiro para a delimitação dos direitos processuais adquiridos

7.2. Direitos subjetivos ou poderes das partes

7.3. Posições jurídicas das partes

7.4. Poderes das partes dirigidos ao juiz

7.4.1. O direito de ação e o direito intertemporal

7.4.2. Poderes das partes dirigidos ao juiz e direito processual adquirido

7.5. Direitos processuais adquiridos e relações entre as partes

7.6. Direitos processuais adquiridos e institutos bifrontes

7.7. Momentos de aquisição dos direitos processuais adquiridos

Capítulo VIII - Poderes do juiz e direito processual civil intertemporal

8.1. Considerações iniciais

8.2. Poderes do juiz e 'otimização' do sistema de direito processual intertemporal

8.3. Fundamentos para a concessão de poderes ao juiz no controle da eficácia temporal das leis

8.4. Limites dos poderes do juiz no controle da eficácia temporal das leis 
8.5. Modo de funcionamento dos poderes do juiz em matéria de direito intertemporal

8.6. Poderes do juiz e direito processual intertemporal - garantias contra excessos

8.7. Poderes do juiz em matéria de direito intertemporal e competência absoluta: mais uma limitação?

Capítulo IX - Situações jurídicas processuais

9.1. Situações jurídicas versus direitos subjetivos

9.2. Situações jurídicas - noções gerais

9.3. Situações jurídicas processuais - colocação do problemas

9.3.1. Situações jurídicas processuais e suas diferentes acepções

9.3.2. Situações jurídicas processuais e complexidade da relação jurídica processual

9.4. Conclusão do capítulo

Capítulo X - Conclusões

10.1. Síntese das conclusões obtidas durante o trabalho

10.2. Explicações sobre o sistema de direito processual civil intertemporal 


\section{Capítulo I - Apresentação}

\section{Introdução}

Problema antigo que atormenta os juristas ao longo da história é o da aplicação da lei no tempo. Todo aquele que se dispõe a estudar tão tormentosa questão encontra inúmeras dificuldades com a falta de homogeneidade na linguagem; a existência de sistemas que partem de enfoques bastante diferenciados; a multiplicidade de soluções apresentadas por inúmeros doutrinadores no curso da história e, ainda, por ser um tema aplicável a todos os ramos do direito, o que dificulta sobremaneira a elaboração de uma teoria geral que se aplique indistintamente para a solução de problemas afetos a qualquer mudança de legislação, quer se trate de uma lei civil, penal, processual ou administrativa $^{1}$.

Para iniciar a ilustração das dificuldades enfrentadas nesse campo devemos pensar no modo como os fatos jurídicos podem se colocar diante de uma lei ${ }^{2}$ nova.

No momento em que essa lei entra em vigor haverá fatos que se constituíram no passado e nesse tempo produziram seus efeitos, tendo, ao tempo da vigência da nova lei, exaurido a produção de todos os efeitos possíveis. Esses costumam ser denominados pela doutrina, com esteio em idéias

\footnotetext{
${ }^{1}$ Em sua célebre Teoria della retroattività delle leggi o Professor da Universidade de Pisa, CARLO FRANCESCO GABBA, assim define as dificuldades da formulação de uma teoria sobre o tema: "La teoria della retroattività presenta gravi difficultà, nascenti principalmente da due cagioni, cioè: A) dall'indole complessa di molti instituci giuridici, B) dalla indeterminatezza del significato di molte espressioni tecniche, adoperate dalle leggi e dalla giurisprudenza (vol. I, p. 129). Se na época de seus escritos as dificuldades já eram consideráveis, com o passar do tempo elas se agravaram pelo nascimento de correntes partindo de enfoques até então não observados pela doutrina, conforme será demonstrado no curso deste trabalho.

${ }^{2}$ Utilizamos o termo lei para expressar toda a espécie de ato normativo, já que os problemas de direito intertemporal dizem respeito a normas de qualquer natureza, quer sejam constitucionais, leis ordinárias, complementares, medidas provisórias e até atos regulamentares, desde que a solução do problema refira-se exclusivamente ao critério temporal. Caso a inaplicabilidade de uma determinada norma para reger uma relação jurídica se dê em função de fatores diversos (como, por exemplo, a existência de uma regra específica que impeça a aplicabilidade da norma geral para aquela situação) o problema deixa de ser afeto ao direito intertemporal.
} 
cunhadas na época do Direito Justinianeu ${ }^{3}$, de facta praeterita. Existirão outros que se constituíram no passado, mas que permanecem produzindo efeitos durante o tempo de vigência da nova lei. A eles a doutrina normalmente se refere como facta pendentia. Por fim, após a vigência da nova lei advirão novos fatos por ela regrados, os quais são chamados de facta futura.

Divididos assim os fatos jurídicos em função do modo como se apresentam em relação à lei nova, pode-se colocar desde logo um primeiro problema que diz respeito à noção de retroatividade da lei. O que significa dizer que uma lei é retroativa? Será retroativa somente a lei que atinge os facta praeterita ou também a lei que atinge os facta pendentia? É possível que uma lei que atinja facta pendentia seja retroativa e outra que os atinja não o seja ${ }^{4}$ ?

Alterando o enfoque do problema para o campo dos direitos subjetivos, encontraremos na figura dos direitos adquiridos um fator limitador da eficácia da lei nova para reger relações jurídicas pendentes. A lei nova deve respeitar os direitos adquiridos antes de sua vigência, o que muitas vezes impede sua aplicação a relações jurídicas constituídas em momento anterior ao seu império ${ }^{5}$.

Surgem então dúvidas sobre a amplitude do conceito de direitos adquiridos e a possibilidade ou não de traçar o conceito de irretroatividade da lei a partir da noção de que determinados direitos (anteriormente adquiridos) devem permanecer intangíveis.

\footnotetext{
${ }^{3}$ V. a propósito, LIMONGI FRANÇA, A irretroatividade das leis e o direito adquirido, pp. 21-22.

${ }^{4}$ A distinção entre eficácia retroativa da lei e eficácia imediata da forma como a entendemos hoje foi desenvolvida por ROUBIER, em suas obras Les conflits de lois dans le temps e Le droit transitoire. O autor francês, partindo do conceito de situação jurídica, procurou demonstrar que sempre que a lei atingir facta praeterita será retroativa, mas, ao projetar efeitos sobre os facta pendentia, somente poderá ser considerada retroativa se atingir os momentos dinâmicos das situações jurídicas, ou seja, seus momentos de constituição e extinção. Os fundamentos principais do teoria de ROUBIER serão aprofundados no Capítulo III deste trabalho.

${ }^{5} \mathrm{O}$ direito adquirido está na base da teoria clássica ou subjetivista do direito intertemporal, a qual limita a eficácia da lei aos facta pendentia em função da existência ou não de direitos adquiridos. O principal expoente dessa corrente foi o italiano GABBA, que dedicou quatro livros ao tema na sua Teoria della retroattivitá delle leggi.
} 
Ainda no enfoque subjetivo, veremos que as questões de direito intertemporal ganham contornos mais interessantes em ordenamentos como o nosso em que, além da proteção aos direitos adquiridos, o constituinte preserva contra alterações legislativas futuras o ato jurídico perfeito e a coisa julgada. A garantia prevista na Constituição conduz à necessidade de conceituação de cada um desses institutos, bem como à análise do grau de proteção que Ihes são conferidas. Exemplificativamente, pode-se indagar se é a

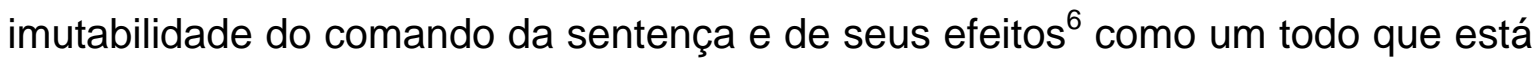
englobada na proteção constitucional da intangibilidade da coisa julgada, ou se somente os direitos subjetivos reconhecidos e afirmados nessa sentença merecem a proteção contra alterações legislativas futuras ${ }^{7}$.

Prosseguindo na análise do tema e trazendo-o para o campo específico do direito processual civil, verificamos que a problemática fica ainda mais rica.

De início, deve-se investigar se é possível falar em direitos adquiridos processuais. A indagação é muito relevante por dois motivos fundamentais. Primeiramente, porque grande parte da doutrina processual moderna afirma que é imprópria a utilização da expressão direito processual ${ }^{8}, 0$ que conduz à indagação se também seria impróprio falar em direito adquirido processual. Por outro lado, o tratamento constitucional conferido ao instituto do direito adquirido impõe ao processualista que se debruce sobre o tema a fim de verificar qual a amplitude dessa garantia no plano do direito processual.

Além disso, se a questão da existência ou não de direitos adquiridos processuais já é um tema em si intrigante e extremamente importante para o estudo do direito processual intertemporal, ela ganha maior importância quando se verifica que, mesmo entre os doutrinadores que expressamente admitem sua existência, não existe uma preocupação com a conceituação desse

\footnotetext{
${ }^{6}$ LIEBMAN, Eficácia e autoridade da sentença e outros estudos sobre a coisa julgada, p. 51.

${ }^{7}$ A questão foi analisada detidamente por FÁBIO GUIDI TABOSA PESSOA em sua tese de doutorado defendida na Faculdade de Direito da Universidade de São Paulo, Elementos para uma teoria do direito intertemporal no processo civil, pp. 62-75. As soluções do autor, juntamente com as principais correntes doutrinárias sobre o tema, serão estudadas no Capítulo VI.

${ }^{8}$ Cf. DINAMARCO, Instituições de direito processual civil, vol. II, pp. 210-211.
} 
instituto e com sua diferenciação dos direitos adquiridos da teoria geral do direito intertemporal $^{9}$.

Com efeito, não é incomum que a afirmativa da existência dos chamados direitos adquiridos processuais seja explicada conjuntamente com o conceito de situação jurídica, misturando-se as teorias subjetivista e objetivista do direito intertemporal ${ }^{10}$, sem que se tenha o cuidado de explicar o modo como se interrelacionam as duas correntes no sistema processual de direito intertemporal.

Diante desse quadro, vê-se que o instituto mais relevante para os teóricos da doutrina clássica - e para os seguidores modernos da teoria sbjetivista $^{11}$-, qual seja o de direito adquirido, que no Brasil detém tratamento constitucional $^{12}$, é muito pouco explorado pela doutrina processual, o que justifica, em nosso sentir, sejam feitos estudos mais aprofundados sobre a matéria.

Por outro lado, deve-se considerar que as particularidades da relação jurídica processual, especialmente do modo como a segurança jurídica atua no direito processual, tornam insuficiente a teoria geral do direito

\footnotetext{
${ }^{9}$ GALENO LACERDA, $O$ novo direito processual civil e os feitos pendentes, p. 3 afirmou que "podemos $e$ devemos considerar a existência de direitos adquiridos processuais, oriundos dos próprios atos ou fatos jurídicos processuais, que emergem, em cada processo, do dinamismo desse relacionamento jurídico complexo. Aliás, o novo Código é expresso, no art. 158, no reconhecimento desses direitos. Existem direitos adquiridos à defesa, à prova, ao recurso, como existem direitos adquiridos ao estado, à posse, ao domínio. Acontece que os direitos subjetivos processuais se configuram no âmbito do direito público e, por isso, sofrem condicionamento resultante do grau de indisponibilidade dos valores sobre os quais incidem". As lições do Professor gaúcho foram acolhidas e louvadas pela doutrina que passou a asseverar a existência dos direitos processuais adquiridos com remição a esses ensinamentos (assim, JOSÉ OLYMPIO DE CASTRO FILHO, Comentários ao Código de Processo Civil, vol. X, pp. 332-336, JOSÉ ROGÉRIO CRUZ E TUCCI, Lineamentos da nova reforma do CPC, p. 166, GUILHERME RIZZO AMARAL, Estudos de Direito intertemporal e processo, p. 17 e GEOVANY JEVEAUX, "Direito adquirido processual", p. 96). Concordamos com o acerto da afirmação nela contida, mas entendemos que o conceito de direito adquirido processual deve ser melhor explicado para que se possa utilizá-lo de maneira mais adequada.

${ }^{10}$ Veja-se assim que GALENO LACERDA fixa primeiramente as premissas de ROUBIER sobre as situações jurídicas e retroatividade e, logo a seguir, assevera categoricamente a existência de direitos adquiridos processuais, fazendo, como se viu na nota anterior, apenas uma remissão ao art. 158 do Código de Processo Civil como norma expressa sobre essa categoria.

${ }^{11}$ Cf. LIMONGI FRANÇA, A irretroatividade ..., pp. 67-73.

${ }^{12}$ Art. $5^{\circ}$, inc. XXXVI, da Constituição Federal. Essa proteção em nível constitucional não é uma constante nos demais ordenamentos. Na Itália, por exemplo, somente a questão da retroatividade da lei penal mais benéfica mereceu tratamento constitucional, reservando-se para o campo da legislação ordinária o regramento geral da matéria (cf. REMO CAPONI, “Tempus regit processum - un appunto sull'efficacia delle norme processuali nel tempo", p. 450).
} 
intertemporal para a solução de muitos problemas relativos ao conflito de leis processuais no tempo.

Soma-se a essas dificuldades o fato de que parte da doutrina apresenta soluções para problemas de direito processual intertemporal que abandonam por completo a corrente subjetivista e se utilizam unicamente do princípio da eficácia imediata da lei processual, inspirado no brocardo tempus regit actum, sem explicar a razão desse posicionamento nem adentrar nas questões mais complexas relativas à identificação da retroatividade da lei processual. Não é incomum, aliás, que os problemas de direito intertemporal sejam solucionados de maneira casuística, com a análise pontual do modo como cada dispositivo de uma determinada lei atingirá os processos pendentes.

Feitas essas observações iniciais, vemos que é necessário um tratamento mais cuidadoso da matéria a fim de permitir ao intérprete e aplicador da lei processual maior segurança na solução dos problemas de sua disciplina.

\subsection{A tese.}

O presente estudo buscará desenhar as linhas gerais do sistema de direito processual civil intertemporal brasileiro.

De início é importante ressaltar que a restrição do estudo ao direito processual civil se faz em função das profundas diferenças entre o trato da matéria nos âmbitos civil e penal, não sendo possível, em nosso entender, traçar uma teoria geral do direito processual intertemporal brasileiro que se aplique tanto para o processo civil como para o penal ${ }^{13}$.

\footnotetext{
${ }^{13}$ A principal diferença do direito processual intertemporal nos âmbitos civil e penal se refere à possibilidade de haver retroatividade da lei processual penal mais benéfica, em decorrência da garantia contida no art. $5^{\circ}$, inc. XL, da Constituição Federal, ou ultratividade da lei anterior quando o novo texto for mais rigoroso. Segundo boa parte da doutrina, as garantias relativas à lei material também se aplicam à lei processual quando essas ostentarem caracteres de direito penal material ou natureza mista. Nesse sentido, v. ROGÉRIO
} 
A sistematização ora proposta se fará tanto para facilitar a solução de problemas relativos à aplicação de leis processuais novas a processos pendentes, como para encontrar os limites de atuação do legislador (ordinário e até mesmo constitucional) em matéria de direito processual civil intertemporal.

Para alcançar esse objetivo dividiremos nossos estudos em quatro partes distintas. $\mathrm{Na}$ primeira delas analisaremos as principais teorias de direito intertemporal, com o que buscaremos traçar um panorama geral dos diferentes sistemas existentes. Nessa etapa faremos uma análise pormenorizada do alcance de determinados conceitos extremamente relevantes ao trato da matéria, como os de direito adquirido e retroatividade da lei, a fim de abrir caminho para a compreensão do modo como nosso sistema garante imunidade a determinados fatos jurídicos contra alterações legislativas futuras.

Fixadas essas idéias iniciais, partiremos para análise dos princípios e regras existentes em nosso ordenamento sobre a matéria, com o que poderemos desenhar as linhas gerais do direito intertemporal brasileiro, sem adentrar ainda na seara processual civil. A análise do sistema geral de direito intertemporal é extremamente relevante, porque nosso legislador processual não tem o hábito de tratar da matéria, o que faz com que o intérprete tenha de se socorrer aos postulados gerais de direito intertemporal para solucionar problemas afetos ao modo de aplicação da lei processual aos feitos pendentes.

A escassez de regras processuais específicas, contudo, não impede nem mesmo recomenda que se deixe de abordar o tema sob um enfoque processual.

Na terceira parte do trabalho é que daremos esse enfoque à matéria. Inicialmente, procuraremos expor as razões que justificam um estudo de direito processual civil intertemporal, momento em que será demonstrada a

LAURIA TUCCI, Direito intertemporal e a nova codificação processual penal, pp. 113-117 e PEDRO DE JESUS JULIOTTI, Direito intertemporal processual penal, pp 63-91. Ainda que existam pontos de contato entre o direito intertemporal processual civil e penal, a diferença que ora se destaca é por demais relevante, a ponto de impedir, em nossa opinião, a sistematização uniforme da matéria. 
insuficiência da teoria geral do direito intertemporal para a solução de grande parte dos problemas relativos à aplicação da lei processual no tempo.

Feita essa justificativa inicial, traçaremos as particularidades do direito processual, tanto no que se refere aos seus conceitos, como às diferenças de aplicações das regras e princípios da teoria geral do direito intertemporal, com o que buscaremos abrir caminho para o desenho final de um sistema de direito processual civil intertemporal.

$\mathrm{Na}$ quarta e última parte desta tese concluiremos nosso objetivo traçando as linhas mestras desse sistema.

\subsection{Relevância e justificativa do estudo}

Quer se adote uma postura favorável ou contrária à opção do legislador pelo aperfeiçoamento do sistema processual brasileiro por meio de alterações pontuais na legislação, não se pode negar que o movimento reformador tornou-se uma realidade com a qual todos os que atuam na área contenciosa cível têm que conviver há pelo menos quinze anos ${ }^{14}$ !

Essa "metamorfose ambulante" que se tornou o
ordenamento processual pátrio torna a disciplina do direito processual intertemporal um tema extremamente em voga, que vem ganhando destaque em inúmeras obras que tratam das últimas reformas do Código de Processo $\mathrm{Civil}^{15}$.

\footnotetext{
${ }^{14}$ Recentemente foi instituída uma Comissão para elaboração de um novo Código de Processo Civil, o que talvez freie o movimento reformador, mas ainda é cedo para saber se essas reformas pontuais serão realmente paralisadas, porque a elaboração de um novo Código em nosso país às vezes se torna uma tarefa tão árdua, que acaba por durar muito tempo e impõe a realização de reformas urgentes durante o seu curso. A aridez dessa tarefa deve-se ao modo como as alterações são introduzidas por nossos parlamentares que não costumam reconhecer sua incapacidade técnica para tratar da matéria e, a despeito de constituir uma Comissão composta por especialistas no assunto, acabam sempre por modificar o projeto inicial, não para alcançar um aperfeiçoamento de nosso instrumento, mas, principalmente, para atender a interesses de determinados setores ou do próprio governo.

${ }^{15}$ Veja-se, a propósito JOSÉ ROGÉRIO CRUZ E TUCCI, Lineamentos da nova reforma do CPC, pp. 166169; CÂNDIDO RANGEL DINAMARCO, A reforma do Código de Processo Civil, pp. 38-47; LUIZ GUILHERME AIDAR BONDIOLI, “Tutela específica: inovações legislativas e questões polêmicas”, pp.
} 
Poder-se-ia imaginar que esse súbito reconhecimento da importância do tema e os inúmeros escritos dedicados a ele tenham o efeito de tornar repetitivo ou até mesmo maçante um estudo inteiramente dedicado ao direito processual civil intertemporal.

Todavia, parece-nos que ainda há espaço para bons estudos nesse campo, especialmente porque a esmagadora maioria das obras que abordam a matéria o fazem de maneira passageira e pouco aprofundada.

Trabalhos específicos sobre direito processual civil intertemporal são poucos ${ }^{16}$ e em sua grande maioria abordam o tema a partir dos pilares da teoria geral do direito intertemporal, fazendo uma análise casuística do modo como as inovações legislativas devem ser aplicadas aos feitos pendentes. Vemos, assim, no trabalho de FÁBIO PESSOA o estudo mais focado nas especificidades do direito processual civil intertemporal, mas, sem qualquer intenção de desmerecer trabalho tão valioso, ainda há muitos caminhos que podem ser trilhados nessa seara, especialmente porque a matéria é por si só demasiadamente ampla ${ }^{17}$.

183-186; LUIZ RODRIGUES WAMBIER, TERESA ARRUDA ALVIM WAMBIER e JOSÉ MIGUEL GARCIA MEDINA, Breves comentários à nova sistemática processual civil, 395-412; ERNANE FIDÉLIS DOS SANTOS, As reformas de 2005 do Código de Processo Civil, pp. 141-143; FLÁVIO CHEIM JORGE, FREDIE DIDIER JR. e MARCELO ABELHA RODRIGUES, A terceira etapa da reforma processual civil, pp. 9-25; HUMBERTO THEODORO JÚNIOR, As novas reformas do Código de Processo Civil, p. 40; RODRIGO MAZZEI, Reforma do CPC, pp. 197-198 e 450-452; MAURÍCIO GIANNICO e outros, As novas reformas do CPC e de outras normas processuais, CASSIO SCARPINELLA BUENO, A nova etapa da reforma do Código de Processo Civil, volumes 1 a 3. Nas três últimas obras citadas o tema é abordado de maneira esparsa com comentários específicos a respeito dos problemas de direito processual intertemporal relativos determinadas técnicas processuais introduzidas pelas reformas.

${ }^{16}$ Dentre as obras brasileiras que tratam especificamente da matéria temos os trabalhos de GALENO LACERDA, O novo direito processual civil e os feitos pendentes, GUILHERME RIZZO AMARAL, Estudos de Direito intertemporal e processo, FÁBIO GUIDI TABOSA PESSOA, tese de doutorado defendida na Faculdade de Direito da Universidade de São Paulo intitulada Elementos para uma teoria do direito intertemporal no processo civil, inédita e LUCAS RISTER DE SOUSA LIMA, Direito intertemporal no processo civil - as normas e situações processuais com natureza de direito material.

${ }^{17}$ Exemplificando a amplitude da matéria, entendemos que alguns dos institutos de direito processual civil, como, v. g., o dos direitos processuais adquiridos, merecem para si um estudo particularizado. Idêntico raciocínio vale para uma análise histórica do tema ou um trabalho comparativo dos diferentes modos como ele é tratado em outros ordenamentos. 
Do quanto pesquisamos, constatamos que a disciplina ora em análise não está suficientemente sistematizada ${ }^{18}$, o que justifica a realização desta tese.

\subsection{Fixação de premissas}

O direito processual não está mais em fase de afirmação de sua autonomia em relação ao direito material. A autonomia do direito processual é uma realidade assim como seu caráter instrumental ${ }^{19}$, o que impõe a todo estudioso do direito processual que mantenha a visão focada na efetividade do processo.

O termo efetividade é hoje entendido de maneira bastante ampla, envolvendo não só a justiça e eqüidade das decisões, como também o tempo e os recursos despendidos para se chegar ao resultado justo, bem como os meios para torná-lo eficaz ${ }^{20}$. Processo efetivo, em síntese, é aquele que atende aos escopos da ciência processual de maneira célere e econômica ${ }^{21}$.

\footnotetext{
${ }^{18}$ É importante frisar, com relação ao caráter inédito desta tese, que o estudo elaborado por FÁBIO PESSOA focou-se principalmente na demonstração de que o direito processual intertemporal deve ser estudado de maneira autônoma e procurou trazer elementos gerais para essa disciplina, sem ter por objetivo sistematizála. São palavras do autor ao justificar seu trabalho: "Esses aspectos nos animaram, enfim, a uma tentativa de abordagem do fenômeno intertemporal processual não com vistas à elaboração desde logo de uma teoria exauriente sobre a matéria - o que, insista-se, nem mesmo quanto às leis em geral consideradas se logrou até o momento -, mas com vistas à obtenção, a partir da moderna processualística, de elementos fundamentais que indiquem ao menos a existência de justificativa para eventual tratamento diferenciado, bem como forneçam as bases, em caso positivo, para essa empreitada”. De nossa parte, também não pretendemos exaurir a matéria, mas tentaremos traçar as linhas gerais do seu sistema. Por outro lado, muitas das conclusões pensadas e analisadas neste trabalho são bastante diferenciadas das obtidas por FÁBIO PESSOA, o que também singulariza o presente estudo.

${ }^{19}$ Cf. DINAMARCO, A instrumentalidade do processo, pp. 18-24 e BEDAQUE, Direito e processo, pp. 1517.

${ }^{20}$ BARBOSA MOREIRA sintetiza o “programa básico” para se alcançar a efetividade do processo em cinco itens, que resumidamente são: (i) existência de instrumentos de tutela adequados; (ii) tais instrumentos devem ser utilizáveis na prática; (iii) existência de condições propícias para assegurar a exata e completa reconstituição dos fatos relevantes; (iv) o resultado do processo deve assegurar à parte vitoriosa o gozo pleno da específica utilidade a que faz jus segundo o ordenamento; (v) o resultado deve ser atingido com o mínimo dispêndio de tempo e energia (“Efetividade do processo e técnica processual”, pp. 17-18).

${ }^{21}$ Nesse sentido, DINAMARCO opta pelo uso da expressão processo civil de resultados, que consiste na consciência de que o valor de todo sistema processual reside na capacidade, que tenha, de propiciar ao sujeito que tiver razão uma situação melhor do que aquela que se encontrava antes do processo" (Instituições de direito processual civil, vol. I, pp. 107-108). Na mesma linha, BEDAQUE entende a
} 
O estudo da problemática da aplicação da lei processual no tempo não deve fugir dessa realidade, sendo de todo desaconselhável que se busque uma análise autônoma do tema sem preocupação com os objetivos da ciência processual ${ }^{22}$. A premissa fundamental do presente estudo, portanto, é a de que é um trabalho voltado à melhor utilização das ferramentas de direito processual para implementar o direito material das partes ${ }^{23}$.

Se a possibilidade de existência de neutralidade em ciências exatas é questionável, em ciências humanas ela é certamente uma utopia e não pretendemos alcançar o impossível. Desde já afirmamos que o presente estudo afilia-se à corrente instrumentalista do processo ${ }^{24}$ e se utilizará do método teleológico como matriz racional para encontrar a melhor solução para os problemas interpretativos que se apresentarem no desenvolver dos trabalhos, por entendemos ser esse o método que mais se afina com os objetivos da ciência processual $\left.\right|^{25}$.

A segunda premissa é de ordem metodológica. Tratando-se de estudo que visa traçar as linhas centrais de um sistema de direito processual

efetividade do processo como sua aptidão para produzir os resultados dele concretamente esperados (Efetividade do processo e técnica processual, p. 32).

${ }^{22}$ DINAMARCO identificou esse fenômeno de afirmação extremada da autonomia da ciência processual, que leva ao distanciamento dos seus verdadeiros escopos, e demonstrou preocupação com os prejuízos que dele podem advir, especialmente em função do apego exagerado à forma em detrimento do conteúdo. A essa necessidade de contenção dos exageros formalistas o Professor das Arcadas denominou de aspecto negativo da instrumentalidade (A instrumentalidade do processo, pp. 267-270).

${ }^{23}$ Seguimos, assim, a orientação de BEDAQUE, Direito e processo - influência do direito material sobre o processo, p. 17, para quem: "A natureza instrumental do direito processual impõe sejam seus institutos concebidos em conformidade $\mathrm{cm}$ as necessidades do direito substancial. Isto é, a eficácia do sistema processual será medida em função de sua utilidade para o ordenamento jurídico material e para a pacificação social. Não interessa, portanto, uma ciência processual conceitualmente perfeita, mas que não consiga atingir os resultados a que se propõe. Menos tecnicismo e mais justiça, é o que se pretende".

${ }^{24}$ Isso não significa que o trabalho seja desprovido de senso crítico e que seguirá cegamente os ensinamentos dos doutrinadores que defendem a corrente instrumentalista. Todas as críticas que entendermos necessárias serão feitas, independentemente da posição doutrinária do autor do pensamento criticado. A ressalva que fazemos é apenas para situar o trabalho dentro de uma linha mestra de pensamentos que entende que a solução dos obstáculos da ciência processual não pode prescindir do método teleológico para alcançar os resultados mais adequados aos objetivos de sua ciência.

${ }^{25}$ A preferência pelo método teleológico se fará nos casos em que essa for uma opção válida e a solução dos problemas interpretativos puder ser feita pela utilização de mais de um método. Tal opção afina-se com a orientação de CARLOS MAXIMILIANO que "manda definir, de modo preciso, o caráter especial da norma e a matéria de que é objeto, e indicar o ramo de Direito a que a mesma pertence, visto variarem o critério de interpretação e as regras aplicáveis em geral, conforme a espécie jurídica de que se trata" (Hermenêutica e aplicação do direito, p. 247). 
civil intertemporal evitaremos a solução casuísta dos problemas de direito intertemporal. Exemplos concretos serão utilizados para demonstrar o acerto ou o equívoco de determinada linha de pensamento, mas não haverá a divisão do trabalho em capítulos específicos para analisar o modo como cada situação jurídica pode ser atingida por uma lei nova. Nossa intenção é justamente fornecer elementos para que o intérprete possa se esquivar da solução casuísta e procure nas bases gerais do sistema a orientação necessária para resolver o problema ${ }^{26}$.

Por fim, devemos remarcar que este estudo tem um lado organizador e outro propositivo, sem ser um trabalho que busque criar um sistema de direito processual intertemporal. Nossa intenção é analisar o direito posto e a partir daí verificar como o ordenamento trata o direito processual civil intertemporal. A partir das regras e princípios existentes é que traçaremos as linhas centrais desse sistema. Somente então, poderemos passar ao trabalho propositivo que consistirá (i) no fornecimento de elementos para justificar o tratamento diferenciado do direito processual intertemporal; (ii) na conceituação dos direitos processuais adquiridos; e (iii) na análise e delimitação dos poderes do juiz para afastar a aplicabilidade imediata da lei.

\subsection{Da utilização do direito estrangeiro}

Não sendo nossa intenção propor um sistema novo de direito processual civil intertemporal, a utilização do direito estrangeiro será feita para compreender o alcance de determinados institutos que já são estudados há séculos por doutrinadores de outros países, ou para justificar pensamentos que se afiliam a correntes ideológicas e/ou filosóficas que contem com adeptos ao redor do globo.

\footnotetext{
${ }^{26}$ Não temos a pretensão de atingir um sistema que evite por completo a solução casuísta, porque temos convicção de que essa é uma tarefa impossível. Caminha nesse sentido o pensamento de DEMOLOMBE, Code Napoleon, vol. I, p. 43: "La théorie de la non-rétroactivité des lois n'est pas, avons-nous dit, susceptible d'être précisément soumise à des règles fixes et invariables". Entendemos que os problemas de direito intertemporal são por demais amplos para que se possa atingir um sistema que solucione de maneira geral e satisfatória a todos eles, mas isso não impede que busquemos fornecer o maior número de elementos para evitar o excesso de casuísmo e reduzir ao máximo o recurso a soluções individualizadas dos problemas de direito processual intertemporal.
} 
$\mathrm{Na}$ maioria dos casos esse recurso se dará mediante o estudo direito do modo como a doutrina daquele país compreende e utiliza determinado instituto jurídico, ou mesmo como aplica algum princípio ou regra jurídica.

Não faremos uso de uma comparação generalizada entre os sistemas de direito intertemporal existentes em outros países, porque entendemos que esse recurso seria útil apenas para a construção de um novo sistema. Para a compreensão do nosso, a análise comparativa limitar-se-á a pontos específicos em que esse recurso permita uma compreensão mais aprofundada do funcionamento dos institutos que o compõem ${ }^{27}$.

\section{Capítulo II - Apontamentos históricos do direito intertemporal}

\subsection{Noções preliminares}

A sociedade evolui e com ela o direito.

A evolução do direito implica na existência de um fenômeno particular às leis humanas, que é a sua temporariedade ${ }^{28}$. As normas sociais $\mathrm{e}$ jurídicas de qualquer natureza detêm um momento de início e outro de fim, dado que não existe norma que tenha sempre existido nem tampouco é razoável supor que haja alguma que subsistirá íntegra enquanto perdurar a humanidade.

\footnotetext{
${ }^{27}$ A propósito da utilidade do método comparativo para a compreensão de determinados institutos jurídicos socorremo-nos das palavras de ANTONIO GAMBARO e RODOLFO SACCO, Sistemi giuridici comparati, p. 2: "La comparazione, scienza giuridica, porta la sua attenzione sulle regole appartenenti ai varii sistemi giuridici, per stabilire in quale misura esse siano identiche e in quale misura differiscano. Questa analisi finirà poi per consentire una migliore conoscenza dei modelli studiati comparativamente".

${ }^{28}$ As leis naturais, diferentemente, só são leis porque universais e atemporais. Assim, por exemplo, a lei da gravidade, a lei da inércia ou qualquer outra lei natural somente é dita lei por não ser passível de alteração.
} 
dimensão temporal.

Essa dimensão temporal pode ser dividida em planos de existência, vigência e eficácia, todos eles com dimensão própria ${ }^{29}$, pois não é necessariamente a partir de sua existência que a lei entra em vigor ou se torna eficaz $^{30}$.

Cada um desses planos diz respeito a um fenômeno particular, sendo mais relevante para o estudo do direito intertemporal o plano da eficácia das leis ${ }^{31}$, porque os problemas de direito intertemporal dizem respeito ao modo como uma dada situação concreta poderá ser atingida pelos efeitos de uma nova norma jurídica. Não se trata de saber se determinada norma jurídica pode ou não ser considerada existente ou vigente. A questão é saber se ela produz efeitos sobre a situação em concreto por ela abstratamente regulada ou se, ao contrário, tal situação permanecerá regida pelo diploma revogado.

A idéia elementar sobre a eficácia das leis no tempo é a de que, visando regular um fato qualquer da vida, as leis devem projetar seus efeitos para os fatos ocorridos após a sua vigência. Por trás dela surgem questões acerca do verdadeiro alcance do conceito de irretroatividade das leis, bem como sobre a extensão dessa limitação. Isso porque, em que pese a noção intuitiva de que as leis, em regra, devem projetar seus efeitos para o futuro, é plenamente possível imaginar a hipótese de uma lei que expressamente estipule a projeção

\footnotetext{
${ }^{29}$ Conforme anota FABIO GUIDI TABOSA PESSOA, Elementos para uma teoria do direito intertemporal no processo civil, p. 12: "Consideradas em tais termos as limitações decorrentes da 'vida útil' das leis, é necessário advertir que nem sempre coincidem os correspondentes planos de existência, vigência $e$ eficácia. Em primeiro lugar, a simples ocorrência de vacatio legis permite que se fale em lei existente no momento atual, mas ainda não vigente ou eficaz; interessa sobretudo, para os objetivos do presente trabalho, indagar todavia da relação entre a eficácia e os outros dois elementos, a ver se restrita a produção dos efeitos naturais da lei ao período de vigência formal. Em outras palavras, trata-se de questionar quais os fatos passíveis de subsunção em seus comandos durante esse período".

${ }^{30}$ A regra geral contida no art. $1^{\circ}$ da Lei de Introdução ao Código Civil é de que a lei começa a vigorar quarenta e cinco dias após a sua publicação.

${ }^{31}$ VICENTE RÁO, O direito e a vida dos direitos, vol. II, pp. 426-427, após observar ser muito comum que ao término do período de vigência algumas leis continuem a produzir efeitos sobre fatos e atos jurídicos, assevera que "É neste caso que a questão surge e nos seguintes têrmos se apresenta: Qual a norma a aplicar-se a êsses efeitos? A nova, ou a antiga, já revogada, que disciplinou o nascimento da situação, ou do direito, de que os mesmos derivam e dependem?’.
} 
de efeitos para o passado. Nesse caso, ter-se-á que verificar qual o limite imposto ao legislador para regulamentar esse tipo de situação ${ }^{32}$.

Do ponto de vista político a decisão sobre os limites da proteção contra a retroatividade das leis leva em consideração duas exigências que se contrapõem: de um lado a necessidade de conferir segurança $e$ estabilidade às relações jurídicas e, de outro, a noção de aprimoramento da legislação, a sugerir que o diploma novo, por ser produto de uma evolução legislativa, deve ser mais apto a reger os fatos jurídicos nele abstratamente previstos $^{33}$.

Com efeito, a idéia de segurança considerada isoladamente talvez conduzisse à imunização de todas as relações jurídicas constituídas antes do seu advento, independentemente de estarem exauridas ou não. Pensando-se apenas na segurança dos participantes dessas relações, seria muito simples eliminar o elemento surpresa decorrente da mudança de legislação fazendo com que as novas leis somente projetassem efeitos para relações jurídicas constituídas após o seu advento.

Tal raciocínio, todavia, esbarra na idéia de maior eficiência que está ínsita na mudança - leia-se aprimoramento - da legislação, o que sugere que a nova lei deva ser utilizada para reger os facta pendentia, desde que não acarrete com isso insegurança para a sociedade.

\footnotetext{
${ }^{32}$ ROBERTO DE RUGGIERO, apoiando-se nas lições de SIMONCELLI, aponta para a necessidade de se separar o estudo do direito intertemporal nos planos abstrato ou filosófico do jurídico. São palavras do autor: "O ter-se muito freqüentemente obliterado a linha de separação entre as duas espécies de investigação, foi uma das causas graves e por vezes invencíveis dificuldades a que a teoria da irretroatividade das leis tem dado lugar. Na verdade, se a investigação especulativa dos princípios (que, inspirando-se na justiça intrínseca e na necessidade de dar segurança às relações, exigem que sejam intangíveis os direitos e as posições jurídicas adquiridas sob o império de uma norma, substituída depois por outra diversa ou contrária) pode ajudar para determinação dos limites do exercício do poder do legislador, a determinação dos princípios positivos só pode fazer-se pelas normas que, concretamente, o mesmo legislador tenha uma vez por outra ditado, ou na sua falta, pelo sistema geral graças à indagação da sua intenção" (Instituições de Direito Civil, vol. I, p. 222).

${ }^{33}$ Nas palavras de RUGGIERO, Instituições..., vol. I , pp. 222-223, "Exige a vida social que a fé na segurança e estabilidade das relações não seja ameaçada pelo receio de que uma lei posterior venha perturbar aquelas que validamente já se formaram; mas contra esta exigência levanta-se a outra, não menos digna de respeito, das mudanças do ordenamento jurídico impostas pela própria evolução da vida social. Somente de uma justa conciliação das duas necessidades opostas pode resultar uma solução idônea do problema." No mesmo sentido, v. VICENTE RÁO, O direito e a vida dos direitos, vol. II, pp. 428-429 e CAIO MÁRIO DA SILVA PEREIRA, Instituições de direito civil, vol. I, pp. 137-140.
} 
É justamente esse equilíbrio de anseios que está na base de qualquer sistema de direito intertemporal.

\subsection{Evolução histórica do direito intertemporal}

$\mathrm{Na}$ introdução desta tese procuramos demonstrar o quão complexa é a disciplina do direito intertemporal. As diferenças de conceitos, enfoques e soluções apresentadas ao longo da história são variáveis que tornam a disciplina um dos campos mais áridos para o estudioso do direito ${ }^{34}$.

Para que se possa alcançar uma compreensão adequada das principais teorias que envolvem a matéria e de seus respectivos conceitos, é de extrema importância a fixação de algumas idéias sobre a evolução histórica da disciplina, especialmente para dirimir as dúvidas que naturalmente surgem na análise dos conceitos de direito adquirido e de retroatividade da lei.

Por uma questão didática dividiremos a evolução histórica do direito intertemporal em dois grandes períodos seguindo em parte a divisão formulada por LIMONGI FRANÇA, segundo a qual pode-se subdividir o estudo do direito intertemporal em três grandes fases a saber: embrionária; pré-científica e científica ${ }^{35}$.

\footnotetext{
${ }^{34}$ Para se ter uma idéia das dificuldades que envolvem a matéria é ilustrativo que a jurisprudência não tenha um posicionamento seguro sobre o conteúdo do conceito de direito adquirido. Uma análise dos julgados de nossas cortes sobre a matéria indica uma variação muito grande desse conceito, ora conferindo-lhe maior amplitude ora menor. Exemplo característico da forma vacilante como a jurisprudência se posiciona sobre a matéria pode ser verificado na comparação do Recurso ex offcio n ${ }^{\circ} 34.551$ (TJSP, rel. Desembargador CARVALHO FILHO, j. 15.03.1960) com o Mandado de Segurança no 25/56 (TJPR, rel. Desembargador SEGISMUNDO GRADOWSKI, j. 14.09.1956) - julgados colacionados por LIMONGI FRANÇA na obra Jurisprudência da irretroatividade e do direito adquirido, pp. 2-4 e 189-191 -, ambos tratando da existência ou não de direito adquirido da viúva de servidor público à pensão instituída por lei. No primeiro caso, entendeu-se que não havia direito adquirido ao fundamento de que "essa pensão não se revestiu do caráter de vitaliciedade e perenidade, de modo a se integrar definitivamente no patrimônio da sua beneficiária enquanto vivesse e se mantivesse viúva” (p. 3), já no segundo, a solução foi radicalmente oposta, restando afirmado que "entende-se, com apoio na doutrina, a nova lei não podia prejudicar direito adquirido. Quando a requerente pediu a concessão do benefício, estava em vigor a Lei 1.557 e desde então constituiuse uma situação jurídica, insuscetível de ser prejudicada por lei posterior”.

${ }^{35}$ A irretroatividade das leis e o direito adquirido, p. 6.
} 
De nossa parte, optamos por unir as duas primeiras fases (embrionária e pré-científica) em um único período, porque não temos a pretensão de formular uma classificação do estudo histórico da matéria, nem adentrar nas controvérsias que envolvem essa tarefa, mas tão somente colher subsídios para facilitar a análise de seus principais institutos.

\subsubsection{Fase "pré-científica"}

O período a que chamamos de pré-científico do direito intertemporal corresponde às fases embrionária e pré-científica da classificação de LIMONGI FRANÇA e vai do início das civilizações até a Exegese e a Escola Histórica do Direito ${ }^{36}$.

Num primeiro momento, na chamada fase embrionária, apesar de não haver um tratamento nitidamente intencional da matéria encontravam-se leis que, de alguma forma, já se preocupavam em assegurar a imunidade de determinadas relações jurídicas contra alterações legislativas.

Via-se, assim, uma consciência rudimentar de que em alguns casos a lei deveria respeitar relações constituídas antes do seu advento, sem que se pudesse encontrar, todavia, princípios norteadores da matéria ${ }^{37}$.

O entendimento de que haveria um início de tratamento legislativo sobre a matéria nos primórdios da civilização até o tempo de CícERO

\footnotetext{
${ }^{36}$ LIMONGI FRANÇA, A irretroatividade..., pp. 6 e ss.. JOSÉ EDUARDO MARTINS CARDOZO, Da retroatividade da lei, pp. 88 e ss., prefere associar o início da fase científica do estudo da matéria com o fim da Idade Média e o início da Idade Moderna, observando que o início do estudo científico do direito intertemporal se deu em função do caráter socialmente problemático que o fenômeno da intertemporalidade jurídica assumiu nesse momento histórico (p. 93).

${ }^{37}$ Para LIMONGI FRANÇA, os "princípios da irretroatividade das leis se fundam no direito natural". Ao justificar essa afirmativa, constata o autor que "a não ser por uma transigência daqueles a quem atinge ou por uma concessão ou imposição do poder que a estabelece, uma norma jurídica não pode atuar antes do termo inicial da sua existência como regra cogente" (A irretroatividade das leis..., p. 8). O fato de o autor afirmar que o princípio em análise tem fundamento no direito natural não significa que os legisladores tenham sempre respeitado intuitivamente esse princípio. A afirmativa do autor fez-se para demonstrar que em muitos casos esse respeito efetivamente ocorreu, a despeito da inexistência completa de parâmetros legais ou científicos para orientar a atividade legiferante.
} 
é controverso. Muitos doutrinadores, seguindo as lições de GAETANO PACE ${ }^{38}$, afirmam que leis como o Código de Hamurabi, o Código de Manu, ou as leis mosaicas, nada dispunham sobre o assunto e, por essa razão, "prevalecia o princípio de que, uma vez editada, a lei era aplicada de modo geral, não importa se quanto ao presente e ao futuro, ou se quanto ao passado"39.

Parece-nos que assiste razão a LIMONGI FRANÇA, em virtude da existência de exemplos de leis nas quais se nota alguma preocupação com relações de direito intertemporal ${ }^{40}$. Todavia, a discussão é pouco relevante para o fim a que nos propomos, sendo mais importante fixar que, ainda que se admita um início de preocupação com a matéria, até o advento das Verritas de CÍCERO o tratamento dado a ela era meramente ocasional e intuitivo, e não traçava orientações gerais.

\footnotetext{
${ }^{38}$ Il diritto transitorio, pp. 27-29. Na realidade, o autor italiano dividiu a análise histórica do direito intertemporal em três períodos a saber: fase negativa, fase da retroatividade como regra e fase da irretroatividade como regra geral. Com relação à fase negativa, procurou demonstrar que nos sistemas teocráticos a lei, por ter caráter divino, nunca é revogada e as novas leis devem sempre permitir uma interpretação que integre o ordenamento, com a manutenção das leis antigas. Justamente por isso, as novas leis funcionam como leis interpretativas e o problema de direito intertemporal não surge, pela inexistência de retroatividade da lei (porque a lei interpretativa não é considerada como uma inovação no sistema).

${ }^{39}$ J. M. OTHON SIDOU, O direito legal: história, interpretação, retroatividade e elaboração das leis, p. 181. Em sentido análogo, CARLOS MAXIMILIANO, Direito intertemporal ou teoria da retroatividade das leis, p. 16.

${ }^{40}$ Nesse sentido, destaca-se da obra Direito intertemporal brasileiro - doutrina da irretroatividade das leis $e$ do direito adquirido, do mesmo autor, exemplo interessante colhido nas leis de Manu. Segundo aponta o Professor da Faculdade de Direito da Universidade de São Paulo, p. 25: "Do ponto-de-vista técnico, a despeito de ser quase um milênio mais nôvo que o Código de Hamurapi, é êste (Código de Manu) um ordenamento mais atrasado, pois aí o fas ainda se confunde com o jus. Não obstante, é curioso notar que, a despeito do caráter divino atribuído ao rei ('formado de partículas tiradas da essência dos principais Deuses'), aí se prescreve uma total subordinação do mesmo ao sistema vigente, sob pena de autodestruição. 'Que o rei não se afaste jamais das regras pelas quais êle determinou o que é legal e o que é ilegal', diz o Livro VII, n. 13. ao mesmo tempo que a regra n. 27 do mesmo livro assevera que 'um príncipe voluptuoso, colérico e inconsiderado recebe a morte do próprio castigo'. Após fazer essas citações o autor conclui, afirmando (p. 26): "Ora, esta subordinação da suprema autoridade aos princípios por ela mesma estabelecidos, não deixa de constituir, por si só, um embrião do respeito ao Direito Adquirido dos súditos, tanto mais que a recomendação é insistentemente repetida em vários outros textos”. Além desse exemplo, a obra analisa outros, colhidos do direito egípcio, mesopotâmico, hebraico e chinês, todos anteriores à civilização greco-romana (pp. 21-32).
} 


\subsubsection{Direito romano}

Foi num discurso de CíCERO criticando um édito de VERRES com efeito retroativo que pela primeira vez tratou-se do direito intertemporal de um modo direto. Em sua crítica CíCERO afirmou a existência de um princípio geral de não retroatividade da lei, demonstrando que o pretor não poderia legislar para tempos anteriores ao seu mandato ${ }^{41}$. A importância dos ensinamentos de CÍCERO, contudo, é maior pelo caráter histórico do que pela influência que teve à sua época, porque o direito intertemporal permaneceu pouco desenvolvido durante os séculos que se seguiram, não se podendo falar que tenha havido uma conscientização dos jurisconsultos e pretores a respeito da existência de um princípio geral de não retroatividade da lei ${ }^{42}$.

Somente no período Pós-Clássico, com as regras de Teodósio I e Teodósio II é que o direito intertemporal efetivamente passou a ter suas bases estabelecidas.

A Primeira Regra Teodosiana, de 393 d.C., estabeleceu que: "Todas as normas não fazem calúnia aos fatos passados, mas regulam apenas os futuros" - omnia constituta non praeteris calumniam faciunt, sed futuris regulam ponant $^{43}$. Nota-se aí a força com que a não retroatividade da lei foi colocada, restando estabelecido, nas palavras de WILSON DE SOUZA CAMPOS BATALHA, o princípio da aplicação da lei apenas para o futuro ${ }^{44}$.

Após explicar que essa regra foi criada para reparar certas injustiças cometidas por TATIANUS - que tinha sido responsável pelo pretório - e por seu filho PROCULUS, ROUBIER observa que a expressão praeteritis calumniam facere indica o reconhecimento de que a lei retroativa poderia ser prejudicial às situações passadas.

\footnotetext{
${ }^{41}$ PAUL ROUBIER , Le droit transitoire, pp. 30-31.

${ }^{42}$ ROUBIER, Le droit transitoire, p. 31.

${ }^{43}$ A tradução para o português foi feita por LIMONGI FRANÇA, A irretroatividade..., pp. 19-20.

${ }^{44}$ Direito intertemporal, p. 60.
} 


$$
\text { Foi, contudo, a Segunda Regra Teodosiana }{ }^{45} \text { a que }
$$
efetivamente trouxe o maior número de elementos para a disciplina do direito intertemporal.

Na tradução de LIMONGI FRANÇA a regra dispôs que: "É norma assentada a de que as leis e Constituições dão forma aos negócios futuros e de que não atingem os fatos passados, a não ser que tenham feito referência expressa, quer ao passado, quer aos negócios pendentes" ${ }^{\text {"46. }}$.

Desse marco do direito intertemporal pode-se tirar algumas conclusões.

Primeiramente, nota-se que o princípio da irretroatividade estava definitivamente previsto na lei. Tal não significava, contudo, que a lei não pudesse ser retroativa. Ela poderia, mas para tanto seria necessário que houvesse uma determinação expressa.

Outra conquista extremamente relevante que é possível encontrar nessa regra é a divisão dos fatos jurídicos ${ }^{47}$ em facta praeterita, facta pendentia e facta futura, sendo os primeiros os sucedidos antes do advento da lei, os segundo aqueles que tiveram início antes da lei, mas que projetam efeitos para o tempo da lei nova, e os últimos os ocorridos após o império da lei.

De se notar ainda, que a regra estabelecia não só a irretroatividade da lei, como limitava sua aplicação imediata com relação aos facta pendentia. Se não houvesse disposição expressa a lei somente se aplicaria aos facta futura.

\footnotetext{
${ }^{45}$ Essa regra data de 440 d.C., época do império de Teodósio II, e foi inserida no Código Justiniano (I, 14, De legisbus et constitutionibus Principum et edictis, 7). V. ROUBIER, Le droit transitoire, p. 33.

${ }^{46}$ A irretroatividade..., p. 20. Eis o texto em latim: "Leges et constitutiones futuris certum est dare formam negotiis, non ad facta praeterita revocari, nisi nominatum et de praeterito tempore, et adhucr pendentibus negotiis cautum sit”.

47 Bem se observa do texto original em latim que a lei falava em facta praeterita e negotiis futuris e pendentibus, mas, a partir das lições de SAVIGNY (Traité du droit romain modernisé, vol. VIII, p. 387,'b’) passou-se a compreender que a expressão contida na lei refere-se aos fatos jurídicos em geral. Nesse sentido, v. ROUBIER, Le droit transitoire, p. 33.
} 
Além de ter inserido a Segunda Regra Teodosiana em sua legislação, JUSTINIANO teve grande importância para o desenvolvimento do direito intertemporal por ter se dedicado a tecer considerações sobre sua ordenação em suas Novelas. Foi devido a essas contribuições que os facta pendentia deixaram de ser entendidos somente como causas controversiais pendentes de transação ou de decisão em juízo para adquirir contornos mais próximos aos de fatos nascidos no império da lei antiga que projetam efeitos para o tempo da lei nova. Além disso, JUSTINIANO foi importante para explicar o fundamento do direito intertemporal que é a fides, ou seja, a confiança no regime vigente $^{48}$.

\subsubsection{Idade Média}

Na Idade Média os subsídios mais relevantes para o estudo da matéria vieram do direito canônico, não havendo muito o que descrever sobre a legislação prevista nos códigos medievais ${ }^{49}$.

A primeira contribuição do direito canônico foi a preservação do princípio da não retroatividade presente no direito romano ${ }^{50}$. Muitos dos avanços alcançados pelos romanos foram deixados de lado pelos conquistadores bárbaros, mas permaneceram vivos graças à sua utilização pelo direito canônico. Além da manutenção do princípio da não retroatividade, o direito canônico ressuscitou a Segunda Regra Teodosiana por meio de uma decretal do Papa GREGÓRIO IX, datada de 1228, onde se encontra não só a previsão de que a lei

\footnotetext{
${ }^{48}$ LIMONGI FRANÇA, Da irretroatividade..., pp. 22-23.

${ }^{49}$ Isso porque nossa análise histórica detém-se tão somente nos momentos em que determinadas noções e conceitos foram criados, a fim de facilitar a compreensão dos institutos que compõem o direito intertemporal de nossos dias. Para uma análise mais detalhada do modo como a matéria era tratada no período, sugerimos as obras de LIMONGI FRANÇA, Da irretroatividade..., pp. 24-27; WILSON DE SOUZA CAMPOS BATALHA, Direito Intertemporal, pp. 65-66; PAUL ROUBIER, Le droit transitoire, pp. 47-51 e GAETANO PACE, Il diritto transitorio , pp. 41-45.

${ }^{50}$ GABBA, Teoria della retroattività..., vol. I, p. 51. A manutenção do princípio da não retroatividade devese a um texto de GREGÓRIO I, datado do ano 598 (ROUBIER, Le droit transitoire, p. 45 e LIMONGI FRANÇA, A irretroatividade..., pp. 27-28).
} 
se aplica aos fatos futuros, como a possibilidade de haver retroatividade, desde que expressamente prevista ${ }^{51}$.

Para ROUBIER a mais importante inovação do direito canônico foi a distinção entre o direito divino e o direito positivo. Segundo a diferenciação feita, o direito divino é superior ao direito humano e as lei que o declaram nada mais fazem do que relembrar um direito que sempre existiu, porque o direito divino é eterno. Justamente por isso, deveriam ter força retroativa máxima (até para atingir fatos já exauridos) ${ }^{52}$.

LIMONGI FRANÇA aponta como traço mais relevante do direito canônico para a matéria a insistência com que o Papa BONIFÁCIO VIII se refere ao Jus Quaesitum e à sua variante Jus Acquisitum. Segundo o autor, embora o instituto do direito adquirido não tenha sido devidamente conceituado no período, foram dessas idéias que posteriormente os estudiosos do tema partiram para desenvolver a sistematização da doutrina do direito adquirido ${ }^{53}$.

\subsubsection{Direito moderno}

$\mathrm{Na}$ Idade Moderna o princípio da irretroatividade da lei foi consolidado por muitos ordenamentos, como conseqüência da formação dos novos Estados.

Posteriormente, com a Revolução Francesa veio a Declaração dos Direitos do Homem e do Cidadão de 1789 que, em seu art. 14 consagrava a irretroatividade da lei em matéria penal. A legislação francesa do

\footnotetext{
${ }^{51}$ ROUBIER, Le droit transitoire, p. 45. O Professor da Universidade de Lyon confere a autoria da decretal de 1.228 a GREGÓRIO IV, certamente por um equívoco de datilografia, dado que o reinado desse papa ocorreu quatro séculos antes (de 827 a 844).

${ }^{52}$ Le droit transitoire, p. 45. LIMONGI FRANÇA discorda desse posicionamento afirmando que a distinção entre leis divinas e leis humanas não foi uma originalidade do direito canônico, pois já estava presente na legislação Justinianéia e no Código Recesvindiano. Prosseguindo em sua crítica, afirma, ainda, que a distinção não teria o condão de servir de critério para a retroatividade, citando um texto de direito divino sobre o adultério de Abraão em que se afirmou a irretroatividade da pena (A irretroatividade..., p. 28).

${ }^{53}$ A irretroatividade..., p. 28.
} 
período até a chegada de NAPOLEÃO ao poder sofreu idas e vindas tendo por um momento conferido tratamento constitucional ao princípio da irretroatividade, não só em matéria penal como em civil, fato que não durou muito tempo.

No período de NAPOLEÃO foi elaborado o Code Civil que em seu art. $2^{\circ}$ estabelece: la loi ne dispose que pour l'avenir; elle n'a point d'effet réctroactif. Esse é o modo como o princípio da irretroatividade da lei está previsto na legislação francesa até os dias atuais.

Também a lei de introdução ao Código Prussiano consagrou o princípio da irretroatividade, mas atualmente esse princípio não está mais previsto no Código Civil Alemão, cuja lei de introdução conta com inúmeros dispositivos de direito transitório para regular especificamente as relações pendentes quando da sua entrada em vigor ${ }^{54}$.

O Código Civil Austríaco de 1.811 trouxe inovação importante ao explicar o alcance do princípio da irretroatividade, limitando a lei a não exercer influência sobre atos anteriores e direitos anteriormente adquiridos ${ }^{55}$.

Mas o ordenamento mais original no tratamento da matéria certamente foi o estadunidense.

Dois traços da legislação desse país são marcantes: (i) seu caráter subjetivista, e (ii) a limitação do legislador ordinário para tratar da matéria em virtude de previsão constitucional sobre o tema.

Com relação à primeira característica, LIMONGI FRANÇA observa que desde antes da independência dos Estados Unidos, a Declaração de Direitos do Estado da Virgínia, de 1.776, já continha previsão que afirmava que "todo poder para suspender leis ou a execução de leis, por qualquer autoridade,

\footnotetext{
${ }^{54}$ WILSON DE SOUZA CAMPOS BATALHA, Direito intertemporal, pp. 68-69.

$55 \S 5^{\circ}$. Gesetze wirken nicht zurück, sie haben daher auf vorhergangene Handlungen und auf vorher erworbene Rechte keinen einfluss. V. ROUBIER, Le droit transitoire, p. 92 e WILSON DE SOUZA CAMPOS BATALHA, Direito intertemporal, p. 68.
} 
sem consentimento dos representantes do povo, é injurioso aos seus direitos, não devendo ser exercido" ${ }^{\prime 56}$.

Posteriormente a matéria foi tratada na Constituição Federal, que não só impediu a edição de leis retroativas (art. $1^{\circ}$, Seção IX, $\left.\S 3^{\circ}\right)^{57}$, como impediu os Estados de editarem leis retroativas e de enfraquecerem por meio da lei a força dos contratos (art. $1^{\circ}$, Seção X, $\left.\S 1^{0}\right)^{58}$.

\subsubsection{Fase "científica"}

No início do século XIX grandes pensadores do direito passaram a se debruçar sobre o tema, dando início ao período que LIMONGI FRANÇA denominou de "fase científica" do direito intertemporal, em oposição à época em que o tema era tratado sem um método científico, de maneira pouco ou nada ordenada.

Um dos primeiros estudos específicos da matéria foi elaborado pelo belga BLONDEAU, que procurou esclarecer os limites da eficácia retroativa da lei em seu Essai sur ce qu'on appelle Effet Rectroactif des Lois. Esse trabalho chegou a receber duras críticas da doutrina, tendo como maior mérito o fornecimento de elementos para a justificação filosófica do princípio da irretroatividade da lei, sem que tenha logrado êxito na tarefa de definir a eficácia retroativa da le $i^{59}$.

Em decorrência das limitações da obra de BLONDEAU o início do estudo científico da matéria é creditado a MERLIN DE DOUAI, cujos

\footnotetext{
${ }^{56}$ A irretroatividade..., p. 34.

${ }^{57}$ Clause 3: No Bill of Attainder or ex post facto Law shall be passed.

58 Clause 1: No State shall (...) pass by any Bill of Attainder, ex post facto Law, or Law impairing the Obligation of Contracts, or grant any Title of Nobility.

${ }^{59}$ ROUBIER, Le droit transitoire, pp. 96-98. O autor francês afirma que a teoria de BLONDEAU lhe parece insignificante, justificando essa afirmativa da seguinte forma "ele se limitou a trazer uma justificativa filosófica da regra da não retroatividade, que é a necessidade de segurança e confiança, mas a construção jurídica é inexistente."
} 
escritos Effet Réctroactif e Effet Réctroatif de la Loi du 17 Nivose An 2 datam dos anos 1.827 e 1.828 , respectivamente ${ }^{60}$.

MERLIN procurou traçar um modelo de direito intertemporal, cujas bases serviram de inspiração para a evolução da teoria clássica do direito adquirido.

Os pontos principais da sua doutrina são: (i) 0 reconhecimento da existência de um princípio geral de irretroatividade da lei, que comporta algumas exceções; e (ii) a busca de definição do conceito de retroatividade da lei.

É justamente ao desenvolver essa última idéia que o autor vincula a noção de irretroatividade com o respeito aos direitos adquiridos e passa a conceituar o que vem a ser esses, bem como a diferenciá-los das faculdades e das expectativas de direito ${ }^{61}$.

Muitos doutrinadores seguiram a linha mestra de seu pensamento, criando sistemas próprios de direito intertemporal fundados na idéia de respeito aos direitos adquiridos ${ }^{62}$. Os escritos do período, cujos principais pontos serão estudados a seguir, fazem parte da chamada "doutrina clássica do direito adquirido"63. Nessa fase é que foi desenvolvida a doutrina de CARLO FRANCESCO GABBA, até hoje um dos principais nomes do direito intertemporal mundial.

Não demorou para que surgissem opositores à essa corrente. As críticas a ela dirigidas buscavam, de um lado demonstrar que o conceito de direito adquirido é pouco claro e insuficiente e, de outro, que a doutrina que se fundamenta em tal conceito é equívoca, por um erro de

\footnotetext{
${ }^{60}$ LIMONGI FRANÇA, A irretroatividade das leis..., p. 41.

61 "Effet rétroactif”, pp. 533-605, esp. pp. 536-540.

62 Dentre eles pode-se citar os trabalhos de SAVIGNY e LASSALE na Alemanha, PACIFICI-MAZZONI e GABBA na Itália e CHABOT DE LALLIER e J. D. MEYER na França. Esse último pode ser considerado um autor franco holandês por ter publicado sua obra Principes sur les questions transitoire em Paris e em Amsterdã, conforme informa ROUBIER, Le droit transitoire, p. 98.

${ }^{63}$ LIMONGI FRANÇA, A irretroatividade das leis..., p. 39.
} 
perspectiva. Nesse sentido, afirmaram que, ao invés de focalizar o direito subjetivo dos participantes de uma relação jurídica, a disciplina do direito intertemporal deveria centralizar-se no conceito de irretroatividade da lei. Das teorias desenvolvidas em oposição à doutrina dos direitos adquiridos a que maior influência exerce até hoje, tanto em doutrina como em legislações, é a de PAUL ROUBIER, que buscou definir o alcance da irretroatividade da lei mediante a análise da situação jurídica.

Posteriormente a doutrina clássica do direito adquirido ganhou novos adeptos que, sem se distanciarem de suas noções fundamentais, procuraram corrigir equívocos de conceitos para rebater as críticas que the tinham sido dirigidas ${ }^{64}$.

No estágio atual, pode-se dizer que as duas principais correntes adotadas pelas legislações ocidentais têm traços do pensamento de GABBA ou de ROUBIER, ou até mesmo de ambos. Justamente por isso, passaremos a expor os principais aspectos de cada um deles.

\section{Capítulo III - Fundamentos do direito intertemporal}

\subsection{Considerações sobre o conceito de retroatividade na teoria clássica}

Ponto de extrema importância para a compreensão das diversas lições sobre direito intertemporal, especialmente as anteriores aos escritos de PAUL ROUBIER, diz respeito ao conteúdo do conceito de retroatividade da lei.

${ }^{64}$ Entre os franceses destacam-se BAUDRY-LACANTINERIE, JOSSERAND e SAVATIER, Na Itália pode-se citar VENZI e FAGELLA e no Brasil, CARLOS MAXIMILIANO, PAULO LACERDA e LIMONGI FRANÇA. 
Isso porque a grande maioria dos autores do período buscava conceituar a retroatividade a partir do momento de nascimento dos fatos (relações; situações) jurídicos regulados pela lei. A retroação não implicava necessariamente uma ação da lei sobre o passado, mas uma ação sobre fatos nascidos antes de seu império ${ }^{65}$.

Era comum, portanto, que se entendesse como retroativa toda lei que atingisse os facta pendentia, independentemente do modo como se daria esse fenômeno ${ }^{66}$. Percebe-se aí uma influência muito grande da Segunda Regra Teodosiana que tanto impedia a ação da lei sobre o passado como também sobre os "negócios pendentes".

Havia, ainda, autores que somente consideravam retroativa a lei que atingisse direitos adquiridos ${ }^{67}$. Nesse particular, é importante ressaltar que a grande preocupação desses doutrinadores era explicar os casos em que a lei poderia atingir os fatos jurídicos nascidos em momento anterior a sua vigência e os casos em que tal não seria possível. Partindo, então, do conceito existente de retroatividade e, buscando dar um sentido ao princípio da irretroatividade da lei, afirmavam que somente poderia ser considerada retroativa a lei que ferisse direitos adquiridos dos participantes das relações jurídicas por ela afetadas ${ }^{68}$.

Perspectiva completamente diferente foi desenvolvida pelo alemão FRIEDRICH AFFOLTER, pela qual o autor deixa de utilizar o termo retroatividade. Segundo suas idéias os problemas de direito intertemporal devem ser solucionados a partir da análise de qual lei deve reger as relações jurídicas.

\footnotetext{
${ }^{65}$ Nesse sentido, v. JOSÉ EDUARDO MARTINS CARDOZO, Da retroatividade ..., pp. 253-254.

${ }^{66}$ No oitavo volume de seu Sistema do direito romano atual SAVIGNY divide o sentido da retroatividade em dois graus diferentes observando que ela pode "se exercer exclusivamente sobre as conseqüências dos atos jurídicos posteriores à lei nova” ou “independentemente dessas conseqüências, pode abranger também o tempo decorrido entre os fatos jurídicos e a nova lei”. Feita essa divisão o autor conclui que "A fórmula transcrita antes (o princípio da não retroatividade), entretanto, nega de modo absoluto à nova lei toda ação sobre conseqüências dos atos anteriores e isso em todos os graus imagináveis” ( p. 303).

${ }^{67}$ MAILHER DE CHASSAT, por exemplo, trata da retroatividade tanto quando a lei atinge atos ou relações passadas, como ao atingir relações pendentes sobre as quais tenha havido decisão definitiva, transação ou das quais decorram direitos adquiridos (Traitè de l'interpretation des lois, p. 265).

${ }^{68}$ Para MERLIN DE DOUAI, a ocorrência da retroatividade dependeria do concurso de duas condições (i) que a lei se voltasse para o passado e lhe alterasse e (ii) que a ele se voltasse e lhe alterasse em prejuízo das pessoas que são objeto de suas disposições (“effet rétroactif”, p. 536). Tal prejuízo, somente se sucederia quando se suprimissem direitos adquiridos.
} 
Assim, o conceito de retroatividade perde lugar para as idéias de exclusão e sobrevivência da lei anterior. A primeira diz respeito aos casos em que se exclui a lei anterior e a relação jurídica passa a ser regida pela lei nova; a segunda referese ao fenômeno de ultratividade da lei, pelo qual uma lei revogada permanece surtindo efeitos para regular relações jurídicas constituídas antes do seu advento $^{69}$.

PAUL ROUBIER elogia o posicionamento adotado por AFFOLTER por entender que ele teve o mérito de eliminar uma terminologia viciosa (associação da retroatividade aos direitos adquiridos), embora tenha discordado do sistema proposto por ele que, segundo o Professor francês, chegava a resultados parecidos com os obtidos pelos teóricos da doutrina clássica $^{70}$.

Os escritos de AFFOLTER colocaram o modo como a lei atinge os fatos jurídicos anteriores à sua constituição no centro do sistema de direito intertemporal, o que abriu caminho para um melhor entendimento do que significa retroatividade e eficácia imediata da lei. Tais conceitos foram bastante explorados por ROUBIER, cuja obra será mais detalhadamente analisada nos tópicos finais deste capítulo. A partir de então generalizou-se o entendimento de que retroativa é a lei que atinge o passado.

\footnotetext{
${ }^{69}$ Apud PAUL ROUBIER, Le droit transitoire, pp. 178-179; LIMONGI FRANÇA, A irretroatividade das leis..., pp. 58-59 e GAETANO PACE, Il diritto transitorio, pp. 218-221. VAREILLES-SOMMIÈRES em seu artigo "Une théorie nouvelle sur la rétroativité des lois" publicado na Révue critique de législation et jurisprudence de 1.893 defendeu que uma lei é retroativa "a) quando cancela no passado os efeitos já produzidos dum ato ou dum fato anterior" ou "b) quando suprime ou modifica para o futuro um dos nossos direitos, em razão dum fato passado”. A menção sobre o fato passado é de extrema importância no pensamento do autor, porque a retroatividade consistiria justamente em conferir uma alteração de disciplina desse fato, sendo daí que viriam as conseqüências futuras que porventura ocasionariam a supressão do direito (pp. 444-468, esp. pp. 444-447), “mas, as leis, que suprimem ou modificam para o futuro um dos nossos direitos, qualquer que ele seja, não são retroativas, quando o não fazem em razão dum fato passado, mas em razão desse direito tomado em si, dos inconvenientes que ele ofereceria d'agora em diante” (p.447). A tradução para o português foi tirada da obra de EDUARDO ESPÍNOLA e EDUARDO ESPÍNOLA FILHO, Da lei... , pp. 197-198.

${ }^{70}$ Le droit transitoire, p. 178. Isso porque a regra principal (Hauptregel) do sistema de AFFOLTER é a sobrevivência da lei antiga para reger as relações jurídicas pendentes.
} 


\subsection{O direito adquirido na teoria clássica}

O conceito de direito adquirido provém da noção de jus quaesitum cunhada pelos pós-glosadores do período medieval ${ }^{71}$. Essa noção pode ser identificada como o embrião do conceito de direito adquirido, que começou a ter contornos mais nítidos a partir da chamada escola da exegese ${ }^{72}$.

Embora a noção de jus quaesitum não estivesse bem delimitada, ela era utilizada para distinguir os "direitos sólida e realmente adquiridos" (jus quaesitum firmum) dos "direitos eventuais" ou "expectativas" (jus existens in spe non autem firmiter quaesitum ${ }^{73}$.

A idéia de proteger direitos adquiridos já estava colocada, embora os doutrinadores da época não tivessem traçado os limites desse conceito. Nota-se também que desde esse período uma das principais preocupações para a devida conceituação dos direitos adquiridos era a sua diferenciação das meras expectativas de direito.

A partir do momento em que o direito intertemporal passou a ser estudado segundo critérios científicos o conceito de direito adquirido mereceu atenção especial da doutrina que, debruçando-se sobre ele, tentou conferir-lhe limites precisos.

GIOVANNI LOMONACO ${ }^{74}$ apresenta as seguintes definições oferecidas ao conceito pelos doutrinadores da época:

MEYER: "São adquiridos os direitos que se tornaram propriedade daquele que os exerce e, portanto, deles pode gozar e dispor pelo modo mais absoluto."

\footnotetext{
${ }^{71}$ PAUL ROUBIER, Le Droit Transitoire, p. 47-51; LIMONGI FRANÇA, A Irretroatividade das leis..., pp. 27-31.

${ }^{72}$ LIMONGI FRANÇA, A irretroatividade das leis..., p. 38.

${ }^{73}$ PAUL ROUBIER, Le Droit Transitoire, p. 49. No mesmo sentido com esteio nas lições de ROUBIER, v. WILSON DE SOUZA CAMPOS BATALHA, Direito intertemporal, p. 88.

${ }^{74}$ Istituzione di Diritto Civile Italiano, vol. I, pp. 72-73.
} 
REINHARDT: "São adquiridos os direitos nascidos de fatos postos em ser, por modo perfeito, antes da nova lei, mas cujos efeitos ainda se não consumaram."

CHRISTIANSEN: "Adquiridos são os direitos que, tendo sua possibilidade abstrata na lei, se uniram a um titular e, ao mesmo tempo, receberam certa determinação perfeita, em virtude de um fato capaz, por lei, de produzir este resultado." 75

Outro autor do período que forneceu uma fórmula para a definição dos direitos adquiridos foi SAVIGNY. Na sua concepção, por manutenção aos direitos adquiridos deve-se entender "as relações jurídicas de uma pessoa determinada, isto é, as partes constitutivas do domínio em que a vontade individual exerce sua independência e não as qualificações abstratas de todos os homens ou de uma classe da sociedade". Além disso, o célebre autor alemão afirmou que "não se deve confundir com os direitos adquiridos as simples expectativas que, baseadas na antiga lei, são destruídas pela nova legislação"76.

A despeito da preocupação em definir o conceito do instituto em análise pode-se notar que os doutrinadores da época ainda estavam bastante distantes da tarefa de fornecer-lhe limites precisos. CARLO FRANCESCO GABBA analisou detidamente esses conceitos (e ainda outros), antes de criar a sua própria definição, entendendo que todos eles eram equívocos.

O conceito de MEYER, por exemplo, não distinguia os direitos consumados daqueles que em parte ou no todo ainda produzirão efeitos, sendo assim uma definição bastante generalizada ${ }^{77}$. Já o de REINHARDT deixava a desejar na sua exatidão e passava a idéia de que só existiriam direitos adquiridos advindos de atos de vontade. Segundo observa GABBA, esse conceito tinha, ao menos, a vantagem de fazer a distinção entre os atos consumados e os

\footnotetext{
${ }^{75}$ A tradução para o português dessas lições foi tirada da obra de VICENTE RÁO, que também as cita em $O$ direito e a vida dos direitos, vol. I, tomo II, p. 437, nota 301.

${ }^{76}$ Sistema do direito romano atual, vol. VIII, pp. 305-306. SAVIGNY alertou também que os direitos sujeitos a condição ou a termo não podem ser confundidos com meras expectativas, afirmando que aqueles "são realmente direitos, porquanto a própria condição cumprida tem um efeito retroativo. A diferença consiste no fato de que a expectativa, quanto a seus resultados, depende da simples vontade de uma pessoa estranha, o que não ocorre para a conditio e para o dies” (p. 306).

${ }^{77}$ GABBA, Teoria della Retroattività..., vol. I, p. 185.
} 
que produzem efeitos para o futuro, suprindo em parte a lacuna deixada por MEYER, que também é vista no conceito de MERLIN ${ }^{78}$.

Ao analisar a doutrina de SAVIGNY sobre os direitos adquiridos, retomou GABBA as explicações do romanista alemão sobre a sua fórmula ${ }^{79}$ e observou que ele limitou o conceito aos direitos privados relativos à propriedade. Em seguida passou a demonstrar a insuficiência dessas lições em virtude da falta de clareza quanto ao significado da expressão independência constante das explicações de SAVIGNY. Tal expressão passaria a idéia de que só existiriam direitos adquiridos irrevogáveis ou, então, de que não seria possível a existência de direitos adquiridos sujeitos a condição, o que na opinião de GABBA não seria correto, porque tanto é possível a existência de um direito adquirido revogável como sujeito a condição ${ }^{80}$. GABBA entendeu ser inexata a definição de CHRISTINASEN, porque existiriam direitos intimamente ligados ao sujeito que, contudo, não se poderiam dizer adquiridos a ponto de impor o respeito da lei, como são, por exemplo os direitos pessoais de índole política ${ }^{81}$.

A insuficiência dessas definições, bem como das teorias existentes sobre o sistema de soluções para os problemas de direito intertemporal, levou GABBA a dedicar quatro livros para o estudo do tema em sua clássica obra Teoria della Retroattività delle Leggi. Os principais aspectos de sua teoria serão abordados nos tópicos seguintes.

\footnotetext{
${ }_{78}^{78}$ Teoria della Retroattività ..., vol. I, p. 188.

${ }^{79}$ Nessa passagem SAVIGNY esclarece que "quando nossa fórmula exige a manutenção dos direitos adquiridos, com isso deve-se somente entender as relações jurídicas de uma pessoa determinada, isto é, as partes constitutivas do domínio em que a vontade individual exerce sua independência e não as qualificações abstratas de todos os homens ou de uma classe da sociedade" (Sistema..., p. 305). A observação de SAVIGNY faz-se para diferenciar os direitos adquiridos das faculdades e das expectativas.

${ }^{80}$ Teoria della Retroattività..., vol I, p. 187. A segunda crítica deve ser entendida como direcionada somente ao conceito de SAVIGNY e não à sua teoria, já que ele afirmou expressamente a possibilidade de existirem direitos adquiridos sujeitos a condição. Talvez a fórmula do seu conceito não fosse das mais exatas, mas suas explicações deixaram bem claras essa possibilidade.

${ }^{81}$ Teoria della Retroattività..., vol. I, p. 188-189.
} 


\subsection{Direito adquirido na obra de GABBA}

O Professor da faculdade de Pisa definiu os direitos adquiridos da seguinte forma:

“É adquirido todo direito que:

a) é conseqüência de um fato idôneo a produzi-lo, em virtude da lei do tempo no qual o fato se viu realizado, embora a ocasião de fazê-lo valer não se tenha apresentado antes da atuação de uma lei nova a respeito do mesmo, e que

b) nos termos da lei sob o império da qual se verificou o fato de onde se origina, entrou imediatamente a fazer parte do patrimônio de quem o adquiriu." ${ }^{\prime 82}$

A primeira constatação que se faz desse conceito é que o mestre italiano admite que os direitos adquiridos sejam conseqüência de um fato, prescindindo, dessa maneira, do elemento vontade para que possam se caracterizar como tal ${ }^{83}$.

Tais fatos deveriam, segundo a lei em vigor, ser idôneos a conferir ao sujeito um direito subjetivo.

Ao mencionar que os fatos devem ter sido realizados, 0 autor, remetendo-se aos ensinamentos de SPANGENBERG, esclareceu que se a origem do direito que se pretende adquirir não tiver se aperfeiçoado como a lei do tempo exigia, essa lei não pode ter uma eficácia que a lei posterior deva respeitar.

A explicação constante da alínea 'b' foi feita para impedir que se incluíssem nesse conceito as faculdades jurídicas e as expectativas de

${ }^{82}$ Teoria della Retroattività..., vol. I, p. 191. A tradução é de LIMONGI FRANÇA, A irretroatividade das leis..., p. 213.

83 Dessa primeira constatação verifica-se uma profunda diferença entre o pensamento de GABBA e o do alemão FERDINAND LASSALE, que em sua Théorie Systematique des Droits Acquis fundamentava todo o sistema de direito intertemporal no respeito à vontade dos sujeitos (tome 1, pp. 65-97) e, assim, somente admitia a existência de direitos adquiridos decorrentes de atos voluntários das partes. 
direito $^{84}$, mas, ao conferir caráter exclusivamente patrimonial aos direitos adquiridos - para distingui-los das faculdades jurídicas - o conceito mereceu inúmeras críticas da doutrina.

Por fim, de se notar que esse conceito abre margem para dúvidas sobre sua abrangência ou não aos direitos sob condição ou termo, em decorrência da afirmação de que é adquirido o direito que entrou imediatamente a fazer parte do patrimônio de seu titular.

A solução para esse problema foi dada pelo próprio autor, conforme demonstraremos no tópico seguinte quando analisaremos os principais aspectos de sua teoria.

Embora GABBA tenha se esforçado demasiadamente para formular um conceito que superasse todas as críticas aos demais até então fornecidos pela doutrina, é importante fixar que, devido à grande complexidade do tema, o verdadeiro conteúdo dos direitos adquiridos somente pode ser aferido pela compreensão da doutrina do Professor italiano, especialmente pela análise que ele mesmo realizou do seu conceito. É imprescindível, portanto, para entender GABBA, que se faça um estudo dos pontos centrais de sua teoria.

\subsection{A doutrina de GABBA}

GABBA fundamentou inteiramente sua teoria no instituto do direito adquirido. Para o Professor italiano o princípio da irretroatividade da lei se explicava a partir do respeito aos direitos adquiridos ${ }^{85}$. Na sua concepção a lei

\footnotetext{
${ }^{84}$ V. Teoria della Retroattività delle Leggi, vol. I, pp. 191-192. Ao formular sua análise do conceito de GABBA observa VICENTE RÁO, O direito e a vida dos direitos, vol. I, tomo II, pp. 438, que: "necessário é, ainda, que, sempre de acôrdo com a lei do tempo, o direito assim nascido se haja, imediatamente, incorporado ao patrimônio de um titular, o que significa não constituirem direitos adquiridos as simples possibilidades, ou faculdades abstratas, nem as simples expectativas de direito".

${ }_{85}^{8}$ Teoria della Retroattività..., vol. I, p. 51 e ss., esp. p. 52.
} 
não deveria retroagir de maneira a atingir tais direitos. Nos outros casos, a retroação seria plenamente aceitável e até mesmo recomendável.

De início deve-se observar que GABBA entendia como retroativa toda lei que atingisse um fato ou relação jurídica iniciados antes do seu império. Não se pode tentar compreender o pensamento do autor a partir da distinção entre efeito imediato e efeito retroativo, tão bem esclarecida na obra de ROUBIER, porque ele não partia dessas premissas.

Para GABBA toda lei que afetasse um facta pendentia seria retroativa, impondo-se assim a diferenciação dos casos em que essa retroatividade seria justa das que seria injusta, sendo certo que o princípio da irretroatividade somente deveria impedir essa última hipótese que, como visto, referia-se aos casos em que a lei atingisse direitos adquiridos.

Outro ponto que merece destaque na definição dos limites da retroatividade na obra de GABBA diz respeito à idéia de que a retroatividade possível de uma lei seria somente a que atingisse os facta pendentia, jamais as relações jurídicas consumadas e terminadas antes do advento da nova lei. $\mathrm{O}$ autor italiano entendia ser uma monstruosidade que o legislador regulasse o passado e, assim, definia como retroatividade impossível a que atingisse a transação a sentença passada em julgado e o pagamento ${ }^{86}$.

Com relação aos direitos adquiridos, além das noções constantes do tópico precedente, é importante sublinhar o modo como GABBA procurou explicá-los.

Após elaborar sua definição, ele demonstrou preocupação em fazer uma análise do conceito de direito adquirido e determinar a sua extensão ${ }^{87}$.

\footnotetext{
${ }^{86}$ Teoria della Rettroatività..., vol I, pp. 34-38.

87 Capítulos 3 e 4 do livro II que trata dos canoni generali in torno alla retroattivitá delle leggi, respectivamente.
} 
A análise do conceito de direito adquirido pode ser dividida em três partes, quais sejam, a do direito concreto ou subjetivo; do direito como elemento do patrimônio e dos fatos aquisitivos ${ }^{88}$.

Com relação à primeira idéia, a preocupação do autor foi de demonstrar a diferença entre a previsão abstrata do direito feita na norma e o direito em concreto, que passa a existir sempre que um determinado fato para o qual a lei preveja a conseqüência de gerar um determinado direito ocorra. Ao formular essa distinção GABBA esclareceu que somente os direitos concretos ou subjetivos é que são capazes de gerar direitos adquiridos, nunca os direitos abstratos ou as previsões legais que permitiriam a existência do direito. Por outro lado, os direitos concretos ou subjetivos devem necessariamente ser decorrentes de uma lei que os preveja expressamente e não de uma liberdade de agir que advenha da inexistência de lei regulamentadora ${ }^{89}$.

Posteriormente GABBA afirmou que para se adquirir um direito não bastava que ele fosse concreto ou subjetivo, mas que pudesse se tornar parte do patrimônio do seu titular, distinção feita para excluir as hipóteses de direitos relativos à condição física ou natural da pessoa - como a cidadania ou seus direitos políticos - cuja possibilidade ou não de aquisição era bastante discutida à época e que para o mestre italiano não eram suscetíveis de aquisição ${ }^{90}$.

\footnotetext{
${ }^{88}$ Teoria della Retroattività..., pp. 193-274. A divisão da obra de GABBA é mais pormenorizada, o resumo nesses três pontos fundamentais foi feito seguindo a orientação de LIMONGI FRANÇA, A irretroatividade das leis..., pp. 51-55.

${ }^{89}$ Teoria della Rettroatività..., vol I, p. 205. Essa constatação partiu da afirmação de um cânone do direito intertemporal, que estatui "non potersi dare diritto acquisito a che non venga emanta una legge nuova, la quale regoli una materia finora non contemplata affatto dalla legislazione” (ob. e loc. cits.).

${ }_{90}^{90}$ Teoria della Rettroatività..., vol I, pp. 206-210. Para explicar os motivos que o levaram a entender que os direitos relativos às condições pessoais de seu titular permaneciam no âmbito de atuação do legislador, não sendo passíveis de aquisição, o autor apoiou-se na noção de que o patrimônio se adquire a partir de algum ato ou fato humano, a que chamou de umana operosità, para os quais a lei prevê a conseqüência de gerar a aquisição de um direito e concluiu que "Diritti concreti e quesiti sono quelli soltanto che dentro la cerchia del potere consentito dalle leggi concernenti le persone e le cose, mirano ad un determinato effetto, da esse leggi contemplato in modo esplicito o implicito, e sorgono negli individui o per virtù dell'umana operosità, $o$ per virtù delle leggi medesima, in seguito a fatti e circostanze e nei modi e alle condizioni da este prestabilite" (ob. cit., p. 210). Mas, no livro segundo de sua obra o autor parece seguir um outro caminho quando explica que os direitos relativos à personalidade passíveis de aquisição são aqueles que geram alguma vantagem ao seu titular. A fórmula acerca da possibilidade de se adquirir direitos pessoais foi por ele resumida da seguinte maneira "In generale possono dirsi diritti acquisiti personali quei diritti i quali immediatamente alla persona rivestita di un dato stato personale, sono direttamente vantaggiosi ad essa
} 
Finalmente, 0 terceiro elemento sobre 0 qual 0 autor debruçou-se para explicar o modo de identificação dos direitos adquiridos diz respeito aos seus fatos aquisitivos.

Segundo suas lições, para que se pudessem considerar adquiridos os direitos era necessário que essa aquisição observasse o cumprimento de quatro requisitos, quais sejam: (i) que os fatos aquisitivos estivessem completos; (ii) que tivessem ocorrido em tempo idôneo ${ }^{91}$; (iii) que o seu titular tivesse capacidade prescrita em lei; e (iv) que tivessem sido observadas as formalidades legais.

Desses requisitos o que traz maiores dificuldades é o primeiro, que diz respeito à necessidade dos fatos aquisitivos estarem completos para que se possa admitir a aquisição dos direitos.

De início demonstra GABBA ser princípio geral que os fatos aquisitivos devem ser verificados por inteiro, antes que se possa dizer adquiridos os direitos que tais fatos estão destinados a produzir ${ }^{92}$. Caso contrário, trata-se de meras expectativas de direito, às quais a lei não confere imunidade.

Feita essa observação, o autor divide os fatos aquisitivos em simples e complexos, sendo os primeiros os que se realizam de uma única vez e os últimos os que se compõem em partes sucessivas realizadas durante um intervalo de tempo.

Com relação aos fatos aquisitivos complexos, GABBA os subdivide em três grupos, quais sejam: (a) aqueles cujas partes sucessivas são praticadas por uma única pessoa; (b) aqueles cujas partes sucessivas são praticadas por duas ou mais pessoas, de maneira independente uma da outra; e (c) aqueles que se compõem de um ato de uma pessoa ao qual deve ser

personna, e costituiscono in pari tempo la vera sostanza dello stato medesimo” (Teoria della retroattività... , vol. 2, pp. 31-32).

${ }^{91}$ No original GABBA fala em che siano stati in essere in tempo idoneo (p. 227). LIMONGI FRANÇA traduz esse requisito da seguinte forma: que tenham sido postos em ato em tempo idôneo. Preferimos utilizar o verbo ocorrer, porque, em nosso entender, passa a idéia que GABBA pretendia e evita-se falar em ato, expressão que indica o elemento vontade que não deve ser incluído no conceito em análise.

92 Teoria della Rettroatività..., vol I, p. 226. 
acrescentado um acontecimento que não está em seu alcance ${ }^{93}$. Feita essa divisão, observou que, para a pergunta acerca da existência de direitos adquiridos decorrentes de fatos complexos inacabados, não seria possível responder nem negativamente nem positivamente, dependendo da existência de um caráter idôneo para gerar a aquisição do direito (o direito ao direito).

E esse caráter idôneo poderia decorrer de uma das seguintes hipóteses: (a) que a parte faltante do fato seja de natureza infalível; (b) que não esteja no poder daquele de quem o direito será exigido impedir a ocorrência da parte faltante do fato aquisitivo; ou (c) que a aquisição que advirá da parte faltante do ato esteja enraizada em um direito adquirido anterior, do qual não seja mais do que um desenvolvimento ou uma transformação ${ }^{94}$.

Esses são, em linhas gerais, os pontos principais de sua teoria. Com o passar dos anos os adeptos da corrente subjetivista trouxeram algumas modificações ao pensamento do Professor pisano, com o intuito de aperfeiçoar sua teoria de modo a superar algumas críticas que lhe foram dirigidas.

No tópico seguinte analisaremos as obras de alguns doutrinadores nacionais que forneceram reparos ao conceito de direito adquirido fornecido por GABBA, a fim de identificar as linhas gerais desse instituto no direito pátrio.

\subsection{O direito adquirido na doutrina pátria}

Antes de analisarmos o conceito que os principais doutrinadores brasileiros do direito intertemporal forneceram ao instituto do direito adquirido é de extrema relevância mencionar que o legislador pátrio o definiu, no

\footnotetext{
93 Teoria della Rettroatività..., vol I, p. 227. Os exemplos que GABBA forneceu para cada uma das hipóteses são: (a) usucapião, em que a prescrição aquisitiva se decompõe da sucessão de ocupação praticados pela mesma pessoa; (b) sucessão testamentária, que supõe a realização de um testamento por uma pessoa e da sua aceitação pelo herdeiro; (c) transmissões unilaterais sujeitas a condição.

${ }^{94}$ Teoria della Rettroatività..., vol I, p. 228.
} 
art. $6^{\circ}$, $\S 2^{\circ}$, da Lei de Introdução ao Código Civil, da seguinte maneira: "consideram-se adquiridos assim os direitos que o seu titular, ou alguém por ele, possa exercer, como aqueles cujo começo do exercício tenha termo pré-fixo, ou condição pré estabelecida inalterável, a arbítrio de outrem"”5.

Nota-se que o legislador pátrio teve pouca preocupação em definir quais direitos são passíveis de aquisição e quais não, deixando ampla margem para a doutrina traçar esses limites. De fato, a lei fala apenas em direitos que possam ser exercidos por seu titular ou por alguém que possa exercê-lo, sem nada falar acerca de quais direitos podem ser passíveis de aquisição e quais não.

Esse é certamente o ponto que mais polêmica gerou na doutrina. Mas, antes de abordarmos o modo como o tema foi desenvolvido é importante fazer uma breve observação sobre os fatos aquisitivos do direito.

O legislador pátrio, pautando-se pelos ensinamentos de GABBA, admitiu que sejam considerados adquiridos não só os direitos decorrentes de fatos aquisitivos simples, como também os que advêm de fatos complexos, notadamente os direitos sujeitos a condição ou a termo, esclarecendo, com relação aos primeiros, que tal condição não poderá ser alterável ao arbítrio de outrem ${ }^{96}$.

Antes mesmo da entrada em vigor da Lei de Introdução ao Código Civil REYNALDO PORCHAT já havia discordado do caráter eminentemente patrimonial da definição de GABBA e entendia que os direitos da personalidade, aos quais chamava de estado civil definitivo, também deveriam ser

\footnotetext{
${ }^{95}$ A análise do conceito legal de direito adquirido é de extrema importância, porque, como bem observam EDUARDO ESPÍNOLA e EDUARDO ESPÍNOLA FILHO, Da lei e da sua obrigatoriedade, do direito intertemporal, com apoio nas lições de STAHL, "é próprio da personalidade, mantida pelo homem no convívio social, o reconhecimento de direitos adquiridos inacessíveis à ação de uma lei nova; mas a determinação dos direitos, que se devem respeitar como adquiridos, pertence ao direito positivo e só por ele pode ser deduzida" (p. 208). De nossa parte, entendemos que o direito positivo pode ou não conceituar o que venha a ser direito adquirido. Na ausência desse conceito a atividade do intérprete será mais livre, enquanto que nos ordenamentos em que existe previsão expressa, sem dúvida o trabalho interpretativo deverá partir desse texto legal.

${ }^{96}$ Ao mencionar outrem o legislador pátrio pretendeu incluir não só os interessados, como ainda os terceiros, de modo a impedir tanto as condições potestativas puras (que sequer condições seriam) como as casuais de gerarem direitos adquiridos. Nesse sentido, v. FÁBIO PESSOA, Elementos para uma teoria..., pp. 65-67.
} 
protegidos. Por esse motivo propôs a ampliação do conceito formulado pelo mestre italiano para constar ao final da alínea 'b' a seguinte passagem ou constituiu o adquirente na posse de um estado civil definitivo ${ }^{97}$.

PAULO DE LACERDA ${ }^{98}$ discordou das críticas elaboradas por PORCHAT, tendo ressalvado que GABBA estendeu a noção de patrimônio contida em sua definição para além do sentido estritamente econômico, admitindo a existência de direitos adquiridos pessoais, que "pertencem imediatamente à pessoa investida de um dado estado pessoal, são diretamente vantajosos a essa pessoa, e constituem, ao mesmo tempo, a verdadeira substância do próprio estado" "99. Assim, o civilista pátrio entende que as ressalvas feitas ao conceito de GABBA são decorrência de uma incompreensão da doutrina desse autor. Parecenos, contudo, que a doutrina de GABBA é pouco clara quanto ao tema, não só porque na parte em que o mestre italiano explica o seu conceito ele mesmo faz uma ressalva quanto à impossibilidade de aquisição de direitos relativos à condição física da pessoa ${ }^{100}$, como, ainda, por ser bastante obscuro o esclarecimento prestado por GABBA sobre esse ponto.

CARLOS MAXIMILIANO foi outro autor nacional que sugeriu alterações ao conceito de direito adquirido proposto por GABBA, sugerindo a seguinte definição: "chama-se adquirido ao direito que se constituiu regular e definitivamente e a cujo respeito se completaram os requisitos legais e de fato

\footnotetext{
${ }^{97}$ Da retroatividade das leis civis, p. 14 e ss.. WILSON DE SOUZA CAMPOS BATALHA, Direito Intertemporal, p. 109, observa que COVIELLO fez idêntica objeção em seu Manuale di diritto civile italiano (p. 115).

${ }^{98}$ Manual do Código Civil Brasileiro, vol. I, pp. 115. Por entender que o conceito de Pacifi-Mazzoni era mais claro e conciso, o autor propôs sua utilização com a substituição da sua frase final, para constar a seguinte sem que esta ainda o tenha feito valer. Com essa alteração, o conceito em análise passaria a ter a seguinte redação: direito adquirido é a conseqüência de um fato idôneo a produzi-la, em virtude da lei do tempo no qual o mesmo se consumou e que antes da atuação da nova lei entrou a fazer parte do patrimônio da pessoa a quem respeita, sem que esta ainda o tenha feito valer (p. 143).

${ }^{99}$ GABBA, Teoria de Rettroattività..., vol. II, p. 38. A tradução para o português foi feita por PAULO DE LACERDA, Manual..., p. 115, nota (3).

${ }^{100}$ São palavras de GABBA: "Todos de fato admitem, por exemplo, que os direitos adquiridos de uma pessoa pelo seu nascimento, ou em processo de tempo pelo simples fato de pertencer a um determinado Estado, ou por meras circunstâncias físicas naturais como a cidadania, os direitos relativos aos menores $e$ aos tutelados, possam com o advento de uma nova lei ser alterados e diminuídos" (Teoria della Rettroattivitá..., vol. I, p. 206 - tradução livre).
} 
para se integrar no patrimônio do respectivo titular, quer tenha sido feito valer, quer não, antes de advir norma posterior em contrário"101.

Já LIMONGI FRANÇA primeiramente considerou que a doutrina de GABBA não está de acordo com o sistema jurídico brasileiro, por afirmar a retroatividade da lei como regra. Quanto ao conceito de direito adquirido, após observar que a locução constante da alínea 'b' se resume a afirmar o caráter patrimonial do direito adquirido, asseverou que essa parte do conceito é demasiadamente prolixa - sendo mais concisa a definição de PACIFI-MAZZONI e, ademais, pouco clara, por não esclarecer se atinge patrimônio exclusivamente material ou se abrange também o moral. Além dessas considerações, ressaltou que na definição de GABBA não ficou suficientemente explicada a possibilidade de haver direito adquirido em conseqüência imediata de disposição de lei, sem a ocorrência de um fato ou ato jurídico particular ${ }^{102}$.

Feitas essas ponderações, propôs o seguinte conceito: "é a conseqüência de uma lei, por via direta ou por intermédio de fato idôneo; conseqüência que, tendo passado a integrar o patrimônio material ou moral do sujeito, não se fez valer antes da vigência de lei nova sobre o mesmo objeto"103.

\subsection{A corrente objetivista}

A despeito de ser até hoje uma das principais doutrinas do direito intertemporal, tendo sido incorporada a muitos ordenamentos jurídicos, a teoria de GABBA encontrou fortes opositores pela frente, os quais não aceitavam que os direitos adquiridos pudessem ser utilizados como principal astro dentro do sistema de direito intertemporal.

\footnotetext{
${ }^{101}$ Direito Intertemporal ou Teoria da Retroatividade das Leis, p. 44.

${ }^{102}$ A irretroatividade das leis..., pp. 214-215.

${ }^{103}$ A irretroatividade das leis..., p. 216.
} 
Os críticos de GABBA afirmavam, primeiramente, uma inconsistência no conceito de direito adquirido, de modo a impossibilitar sua ampla compreensão ${ }^{104}$. Também o número excessivo de exceções vislumbradas pelo autor italiano para casos em que não se aplicaria seu conceito foi utilizado como fator para negar a validade de sua teoria ${ }^{105}$.

Mas, além de criticarem o conceito de GABBA imputandoIhe um caráter vago e fugidio ${ }^{106}$, alguns doutrinadores procuraram demonstrar que a teoria subjetivista partia de premissas equivocadas, porque a proteção contra alterações legislativas futuras não deveria ser entendida do ponto de vista dos direitos individuais, mas das relações (ou situações, dependendo da teoria) jurídicas em si consideradas ${ }^{107}$.

A segurança que se esperaria do sistema não seria simplesmente contra atentados a direitos individuais previamente adquiridos, mas contra alterações que atingissem relações ou situações jurídicas constituídas antes do advento da nova lei.

Muitas doutrinas foram criadas a partir de então ${ }^{108}$, procurando um critério objetivo para a solução dos problemas de direito intertemporal. O modo como a lei pode ou não afetar as relações (ou situações) pendentes quando do seu advento passou a ser colocado no centro de

\footnotetext{
${ }^{104}$ Nesse sentido, v. ROBERTO DE RUGGIERO, Instituições de direito civil, vol. I, p. 228,

${ }^{105}$ Cf. RÁO, O direito..., p. 440.

${ }^{106}$ Expressão utilizada por WILSON DE SOUZA CAMPOS BATALHA, Direito Intertemporal, p. 118. Em sentido análogo ROUBIER destaca as palavras de HOFFMANN, que proclamou "assez d'illusions! ne nous trompons pas plus longtemps! nous pourrons tourner et retourner cette preposition, d'après laquelle les droits acquis doivent être respectés par la législateur, nous n'en tirerons rien. C'est simplesment un mot: car sous ce terme de droits acquis, on entend justement les droits qui doivent être respectés par le législateur: c'est donc idem per idem! (Le droit transitoire, p. 168).

${ }^{107}$ Bastante ilustrativa nesse sentido é a seguinte passagem de FRANCESCO FERRARA, trattato di diritto civile italiano, vol. I, pp. 263-264:"Ma la teoria in sè del diritto quesito è viziosa, perchè fraintende la ragione della irretroattività, che non è quella di proteggere diritti soggettivi, ma obbiettivamente rapporti giuridici. Certo il più delle volte l'intangibilità dei fatti compiuti importa come conseguenza quella dei diritti che ne dipendono, ma non sempre questa coincidenza avviene, perchè sono protetti dei fatti giuridici che non attribuiscono diritti soggettivi”.

${ }^{108}$ Dentre elas pode-se mencionar a teoria de AFFOLTER sobre a exclusão, desenvolvida nas obras Geschchte des Intertemporalen Privatrechts e System des Deutschen Burgerlichen Ubergangsrechts a primeira de 1.902 e a segunda de 1.903) e a de CHIRONI e ABELLO sobre o fatto compiutto (Trattato di diritto civile italiano), também da mesma época (1.904).
} 
observação dos problemas de direito intertemporal, deixando-se um pouco de lado a existência ou não de direitos adquiridos ${ }^{109}$.

\subsubsection{A importância de PAUL ROUBIER para o direito brasileiro}

Dentre os principais expoentes da corrente objetivista destaca-se o Professor da Faculdade de Direito e Ciências Econômicas de Lyon, PAUL ROUBIER. Seu trabalho é citado à exaustão pela grande maioria dos doutrinadores posteriores a ele, e em terras brasileiras exerceu - e continua a exercer - forte influência, sendo amplamente admitido o conceito por ele fornecido de retroatividade da lei e de sua eficácia imediata.

Conforme veremos no capítulo seguinte, durante um curto período de nossa história o sistema de ROUBIER foi adotado isoladamente em nosso ordenamento, em momento no qual o legislador distanciou-se da doutrina dos direitos adquiridos.

Atualmente, em que pese a adoção de um sistema preponderantemente fundado nos direitos adquiridos, a influência de ROUBIER ainda é marcante, especialmente porque a Lei de Introdução ao Código Civil faz menção expressa à eficácia imediata da lei.

Não fosse por esses motivos, o conhecimento das lições de ROUBIER deveriam ser expostos pela clareza com que eliminou dúvidas

\footnotetext{
109 A propósito da colocação dos efeitos da lei como centro das teorias objetivistas, observa FABIO PESSOA, Elementos para uma teoria do direito intertemporal no processo civil, p. 29, que: "Na verdade, precisa a compreensão do fenômeno a partir de uma ótica objetiva no plano temporal - isso, é bom que se diga, independentemente da filiação doutrinária -, considerando a extensão dos efeitos da lei, em si mesmos, com abstração na medida do possível da natureza do texto legal inovador e de sua admissibilidade num dado ordenamento ou momento histórico (a retroação benigna, nesse sentido, é certamente retroatividade, nem por isso deixando de ser compatível com a maioria dos sistemas jurídicos). Dessa forma, o que cabe perquirir é se, ao fim e ao cabo, a lei se pretende expressamente aplicável a fatos passados, ou se, mesmo não declaradamente, termina por criar efeito correspondente conforme a aplicação que se lhe dê, pouco importando se benéfica ou prejudicial a retroação assim caracterizada, se capaz de afetar ou não direito adquirido ou ainda se permitida ou não no caso concreto; reconhecida objetivamente a existência de retroação, apenas então é que passa a importar o exame da respectiva repercussão jurídica”.
} 
conceituais, e por ter chamado à atenção para um modo bastante diferenciado de fundamentar o princípio da eficácia imediata da lei. Feitas essas explicações iniciais, passamos ao estudo dessa doutrina.

\subsection{Principais aspectos da obra de ROUBIER}

ROUBIER dividiu o problema do direito intertemporal em duas análises fundamentais. De um lado, a compreensão do significado da retroatividade da lei. De outro, a identificação dos casos em que a lei deve ter eficácia imediata e daqueles em que a lei revogada deverá continuar projetando efeitos sobre situações constituídas antes do seu advento (survie de la loi ancienne $)^{110}$.

Em linhas gerais a teoria de ROUBIER pode ser assim resumida: a lei não deve ter efeito retroativo, a não ser que o legislador expressamente o preveja, sendo essa hipótese absolutamente excepcional. A eficácia imediata da lei é a regra geral para regulamentar as situações jurídicas decorrentes da lei, e a sobrevivência da lei antiga a regra geral para as situações contratuais.

\subsection{A retroatividade da lei na teoria de ROUBIER}

Como não poderia deixar de ser, ROUBIER traça sua teoria a partir do ordenamento francês em que a regra da irretroatividade da lei está prevista no art. $2^{\circ}$ do Código Civil, que prescreve: a lei só dispõe para o futuro, ela não tem efeito retroativo. Esse dispositivo é a base fundamental do direito intertemporal francês até os dias atuais.

\footnotetext{
${ }^{110}$ Les conflits de loi dans le temps e Le droit transitoire. A última obra é uma versão final da primeira. A essência do pensamento do autor está exposta de maneira idêntica nos dois trabalhos.
} 
O Professor da Faculdade de Lyon observou que a lei francesa não fala em direitos adquiridos, sendo equívoca qualquer tentativa de explicação do significado da retroatividade da lei a partir desse conceito. Assim, demonstrou que a lei somente deve ser considerada retroativa quando projetar seus efeitos para o passado. Caso ela atinja o presente (ou o futuro), não será correto falar em retroatividade, mas em efeito imediato da lei $i^{111}$.

Feita essa distinção, observou que a irretroatividade é uma regra geral expressa no sistema francês em virtude do disposto no art. $2^{\circ}$ do Código Civil $^{112}$. Assim, se a lei nada dispuser em contrário, ela não poderá ser aplicada a fatos anteriores a sua entrada em vigor.

Da regra da não retroatividade percebe-se que tanto as situações ocorridas e exauridas no passado como os efeitos pretéritos das situações pendentes estarão imunizados contra alterações legislativas futuras ${ }^{113}$. Como a lei não deve projetar efeitos para o tempo anterior a sua vigência ela não deve atingir as situações consumadas antes do seu advento e nem mesmo as partes de uma situação pendente que foram praticadas sob o império da lei anterior.

Ponto de extrema relevância na teoria de ROUBIER é o modo como uma lei atinge as situações jurídicas em curso no momento de sua entrada em vigor. Ensina o Professor francês que a identificação do fenômeno da retroatividade da lei muitas vezes não é aferível somente pela observância do momento em que a lei passa a ser aplicada. Não basta dizer que a lei terá eficácia para reger os efeitos das situações jurídicas posteriores à sua entrada em vigor para garantir que ela não será retroativa, porque, dependendo do modo como ela atingir as situações em curso, poderá afetar a constituição ou a extinção

\footnotetext{
111 "La base fondamentale de la science des conflits de lois dans le temps, c'est la distinction de l'effet retroactif et de l'effet immédiat de la loi. Cela paraît une doneé très simple: l'effet rétroactif, c'est l'application dans le passé; l'effet immédiat, l'application dans le present" (Le droit transitoire, p. 177).

112 "L'effet rétroactif de la loi est strictment prohibé par l'article 2 du Code civil: l'interprète devra définir la rétroactivité et proscrire toute application rétroative de la loi” (Le droit transitoire, p. 179).

${ }^{113}$ Le droit transitoire, p. 292.
} 
da situação jurídica estabelecida antes de sua vigência, o que implica em retroatividade da lei ${ }^{114}$.

Para explicar essa idéia ROUBIER observa que muitas vezes as situações jurídicas não se realizam num único momento, mas se desenvolvem no tempo. O fenômeno da retroatividade não se restringe unicamente à análise do tempo em que as leis atingem as situações jurídicas, ou seja, não basta comparar o início da vigência da lei com a data em que ela produzirá um efeito direto sobre a situação jurídica em curso para identificar se essa lei será ou não retroativa, mas impõe ao intérprete uma observância dos momentos da situação jurídica que são atingidos pela nova lei.

Nesse sentido, ROUBIER divide as situações jurídicas em dois momentos distintos, aos quais chama de fase estática e fase dinâmica da situação jurídica. A fase dinâmica corresponde aos momentos de formação e extinção da situação jurídica e a fase estática ao momento em que essa situação produz efeitos.

Se a lei nova atingir os fatos constitutivos ou extintivos de uma determinada situação jurídica terá efeito retroativo. Caso contrário, não ${ }^{115}$. Assim, se uma determinada situação jurídica foi constituída (ou extinta) validamente conforme as leis do tempo em que esse fato ocorreu, uma nova lei que venha a criar novos requisitos para a constituição (ou extinção) dessa situação jurídica não poderá atingi-la - ainda que seja para determinar que se regularize essa situação em determinado prazo - sem que haja retroatividade. Ao conferir uma conseqüência de invalidar um ato constituído regularmente conforme a lei do seu tempo a lei projeta efeitos para o passado, mesmo se respeitar os efeitos que esse ato produziu até a entrada em vigor da nova lei ${ }^{116}$.

\footnotetext{
${ }^{114}$ Le droit transitoire, pp. 181-183.

${ }^{115}$ Le droit transitoire, p. 183).

116 “'Les lois qui governent la constitution d'une situation juridique ne peuvent porter atteinte, sans rétroactivité, aux situations juridiques antérieurment constituées'. Il résulte de là qu'une situation juridique valablement étblie selon la loi alors en vigueur ne peut être tenue pour irrégulière en vertu d'une loi postérieure; ou, en d'autres termes, la validité de cette situation, selon la loi du jour de sa création, ne peut être mise en échec par une loi postérieure.” (Le droit transitoire,p. 185)
} 
Com relação aos efeitos da situação jurídica (fase estática) a solução do problema é a seguinte: a nova lei que regulamenta os efeitos de uma situação jurídica pendente deverá respeitar os efeitos já produzidos antes de sua entrada em vigor, mas atingirá os efeitos futuros que ocorrerem depois de sua vigência $^{117}$.

A formulação dessa idéia parece demasiadamente simples, mas, na realidade, esconde um problema quase tão complexo quanto o de diferenciar os direitos adquiridos das expectativas de direito.

Isso porque, da mesma maneira que GABBA teve que analisar os fatos aquisitivos complexos para expor o alcance de sua teoria, ROUBIER precisou diferenciar as situações que se constituem (ou se extinguem) num único momento das situações que dependem de mais de um ato ou fato para se constituírem (ou extinguirem) ${ }^{118}$.

Nos primeiros casos a solução é bem simples. Realizandose a fase dinâmica em um único momento, bastará ao intérprete verificar se o fato constitutivo ou extintivo já ocorreu e analisar se a nova lei atinge esse fato para saber se ela é ou não retroativa. A fórmula aplicável será quase matemática: se a constituição (ou extinção) da situação jurídica tiver ocorrido antes da vigência da lei, ela se regerá pela lei antiga. Caso contrário, pela lei nova.

Mas existem circunstâncias em que a constituição da situação jurídica se dá em certo período de tempo. Tais circunstâncias podem ser divididas em dois grupos: de um lado estão as situações em que a constituição (ou extinção) requer certo estado de fato continuado no tempo, como, por exemplo, a prescrição aquisitiva (ou extintiva) no usucapião; no outro grupo encontram-se as situações formadas pela presença de elementos sucessivos, que ocorrem cada um em diferentes momentos no tempo, como a sucessão

\footnotetext{
${ }^{117}$ Le droit transitoire, p. 183.

${ }^{118}$ Le droit transitoire, pp. 184-185.
} 
testamentária que requer a elaboração válida de um testamento e a morte do testador para que seja iniciada ${ }^{119}$.

O problema não surge se todos esses elementos tiverem sido praticados antes da mudança de legislação, eis que nesse caso a questão será idêntica à das situações formadas por um único ato. Se somente parte desses fatos tiver ocorrido, a questão torna-se mais complexa.

Com relação às situações jurídicas a formação continuada, a regra será a de efeito imediato da lei sobre a situação em curso de formação, respeitando-se os fatos que tenham ocorrido no passado e conferindo-lhes um valor próprio. Assim, se uma lei aumenta o lapso temporal da prescrição aquisitiva, o possuidor não terá direito ao usucapião sob as condições da lei antiga. A situação jurídica de detentor do direito ao usucapião não se completou e a lei que trata da matéria não será, portanto, retroativa ao atingir essa situação. Contudo, a posse exercida no tempo pretérito terá valor jurídico e poderá ser computada para efeito de constituir a situação jurídica segundo os critérios da nova lei ${ }^{120}$.

Também para as situações jurídicas formadas por elementos sucessivos a regra é da eficácia imediata da lei, respeitando-se os atos validamente praticados. O legislador poderá criar novos requisitos para a constituição da situação jurídica em curso de formação, ou mesmo alterar os elementos faltantes, mas deverá respeitar os já existentes ${ }^{121}$.

Para exemplificar o problema o autor trouxe a questão da sucessão testamentária, em que a situação do sucessor se constitui através da conjugação de dois elementos (i) a elaboração do testamento e (ii) a morte do

\footnotetext{
${ }^{119}$ Le droit transitoire, p. 184.

${ }^{120}$ Le droit transitoire, pp. 297-301.

${ }^{121}$ ROUBIER analisou a questão a partir da divisão entre situações formadas por atos entre vivos e a partir de atos a causa de morte (Le droit transitoire, pp. 302-314), mas a solução apresentada é a mesma. A dificuldade encontrada nos casos de situação formada com a morte de uma pessoa consiste na compreensão do momento em que deve ser aferida a validade do ato praticado. Assim, por exemplo, a formalidade exigida para um testamento deve ser aferida no momento em que ele é redigido. Contudo, seu conteúdo deve estar de acordo com a lei do dia do falecimento, porque tratando-se de disposição de última vontade, essa vontade somente pode produzir efeito a partir do momento do falecimento.
} 
testador. A elaboração do testamento é ato jurídico que tem seus requisitos previstos em lei. Se após sua elaboração uma nova lei vier a aumentar a idade mínima para testar, ela não poderá atingir o testamento já realizado sem ser retroativa, porque, ainda que a sucessão não tenha se completado, aquele elemento de sua constituição já estava completo e já detinha valor jurídico particular $^{122}$.

\subsection{Eficácia imediata da lei e sobrevivência da lei revogada}

Conforme já foi mencionado, ROUBIER sistematiza o direito transitório a partir das noções de retroatividade, eficácia imediata da lei e sobrevivência da lei revogada.

A retroatividade é vedada por lei ${ }^{123}$ e não cabe ao juiz interpretar se uma lei que não contenha cláusula expressa de retroatividade deve ou não ser aplicada retroativamente. $\mathrm{Na}$ ausência de disposição expressa, sua tarefa será meramente de identificar se a aplicação da lei a determinadas situações em curso é ou não retroativa e, caso seja, deverá afastar a produção de efeitos da lei nova sobre essa situação ${ }^{124}$.

Com relação à eficácia imediata, inexistindo regra que a imponha, caberá ao intérprete identificar em quais casos a lei deverá ter eficácia imediata sobre as situações em curso, e em quais casos a lei revogada deverá

\footnotetext{
${ }^{122}$ Le droit transitoire, pp. 311-312.

123 Nota-se, portanto, que o fundamento principal da irretroatividade da lei na obra de ROUBIER é a existência de previsão legal. Mas, além de estar prevista em lei ordinária, a irretroatividade da lei "representa um limite à ação das leis no tempo, e ela constitui um princípio que se impõe ao legislador, senão como regra jurídica, ao menos como regra científica” (Le droit transitoire, p. 224). Com essa afirmativa ROUBIER não pretende impedir o legislador de criar leis retroativas, mas reforçar que os casos em que ele deverá fazê-lo são absolutamente excepcionais.

${ }^{124}$ Assim, se ao legislador é possível derrogar a disposição que veda a retroatividade da lei, criando leis retroativas - já que a disposição que veda a retroatividade está contida em uma lei ordinária (art. $2^{\circ}$ do Código Civil Francês) -, ao intérprete isso não é possível. Daí se conclui que todo e qualquer efeito retroativo de uma lei deve ser expressamente previsto pelo legislador, não se admitindo interpretações que a presumam ou a entendam tacitamente prevista (Le droit transitoire, p. 180).
} 
permanecer viva (survie) produzindo efeitos sobre as situações em curso. A esse último fenômeno nosso direito denomina ultratividade da lei ${ }^{125}$.

Para responder qual a regra geral a ser aplicada às situações em curso, ROUBIER primeiramente coloca de um lado as situações em curso de formação ou de extinção, para afirmar que quanto a elas a doutrina não tem dúvida em admitir que a lei tenha efeito imediato ${ }^{126}$. De outro lado o autor coloca as situações em curso de efeito, observando que quanto a essas existem resistências muito fortes, repousadas na doutrina dos direitos adquiridos, quanto à concessão de efeitos imediatos da lei para regê-las ${ }^{127}$. Feita essa observação, subdivide as situações em curso de efeito em duas categorias, a saber, situações jurídicas legais e situações jurídicas contratuais. Para as primeiras a regra é a submissão à eficácia imediata da $l \mathrm{i}^{128}$, enquanto que as segundas permanecem sendo regidas pela lei antiga ${ }^{129}$.

O fundamento principal para que a lei tenha eficácia imediata com relação às situações jurídicas legais consiste na unidade do direito. Adotando-se o princípio contrário resultaria inevitável que situações idênticas fossem regidas por leis diferentes dentro de um mesmo país. A submissão do regime da lei, em oposição ao dos costumes, tem por conseqüência direta a unidade da legislação do país e, assim, "o legislador que desempenha a tarefa de fazer reinar uma certa ordem, por ele escolhida, para as relações jurídicas, não pode suportar a concorrência de outra lei"130.

No que se refere às situações contratuais, o fundamento para justificar a sobrevivência da lei revogada é justamente o oposto, a diversidade. Explica ROUBIER que no direito moderno o contrato é o instrumento de diferenciação dos indivíduos, e corresponde assim a uma necessidade capital

\footnotetext{
${ }^{125}$ FABIO PESSOA, Elementos para uma teoria..., p. 14.

${ }^{126}$ Respeitando, contudo, os fatos anteriormente constituídos conforme visto no tópico precedente.

${ }^{127}$ Le droit transitoire, p. 293.

${ }^{128}$ Le droit transitoire, pp. 314 e ss..

${ }^{129}$ Le droit transitoire, pp. 360 e ss..

${ }^{130}$ Le droit transitoire, pp. 345-346. Como afirmado esse é o fundamento principal e definitivo para justificar o princípio geral de eficácia imediata para reger as situações jurídicas legais em curso. ROUBIER admite que existam outras justificativas, mas todas elas são insuficientes para permitir a conclusão de que esse princípio realmente exista (v. pp. 340-345).
} 
das sociedades humanas. Como nos estados democráticos de direito todos são iguais perante a lei, o contrato é o único instrumento da diversidade jurídica ${ }^{131}$.

\subsection{Críticas à teoria de ROUBIER}

A principal crítica dirigida à doutrina de GABBA também se aplica à construção de ROUBIER. Isso porque, se de um lado o conceito de direito adquirido foi entendido como pouco claro e com questionável possibilidade de ser utilizado para solucionar os problemas de direito intertemporal, também a noção de situação jurídica é um tanto obscura ${ }^{132}$ e traz as mesmas dificuldades para o bom desempenho do direito intertemporal que existe na teoria clássica.

De fato percebe-se que também ROUBIER teve bastante dificuldade em demonstrar a aplicabilidade prática de seu sistema, o que se deve à complexidade da matéria, como já havia sido alertado por GABBA ${ }^{133}$.

Nota-se daí que tanto as críticas feitas à doutrina clássica como às direcionadas aos objetivistas não parecem justas quando proclamam por um sistema mais simples de direito intertemporal. Essa simplicidade jamais existiu em qualquer dos sistemas que foram apresentados ${ }^{134}$.

\footnotetext{
${ }^{131}$ Voltaremos ao tema no tópico, 5.3.2 adiante quando analisaremos com mais profundidade os fundamentos da teoria objetivista.

${ }^{132}$ Nas palavras de LIMONGI FRANÇA, A irretroatividade das leis..., p. 66: "A despeito das críticas feitas pelo autor à 'imprecisão' da idéia de Direito Adquirido, o fato é que a noção de situação jurídica é ainda mais fluida. Em vão tentou deslindá-la numa monografia específica Droits Subjectifs et Situations Juridiques, onde, de resto, nos deixa o mestre a frustradora impressão de um esboço inacabado e sem estrutura".

${ }^{133}$ V. nota 1, acima.

${ }^{134}$ Em sentido análogo RENÉ SAVATIER, Cours de droit civil, vol. I, p. 12, observa que "Plusieurs auteurs ont critiqué la distinction des droits acquis et des simples expectatives, comme n'étant pas suffisamment claire; mais les critères qu'ils présentent pour apprécier la non-rétroactivité des lois ne sont pas plus précis". Veja-se, assim, que AFFOLTER desce em minúcias para explicar os diferentes graus de exclusividade da lei (cf. ROUBIER, Le drot transitoire, pp. 138-141 e LIMONGI FRANÇA, A irretroatividade das leis... , pp. 58-59) e os seguidores da doutrina do fatto compiuto também encontram dificuldades para definir quando um ato pode ser considerado realizado para fins de proteção contra alterações legislativas (v. LIMONGI FRANÇA, A irretroatividade das leis..., pp. 55-58 e CHIRONI, Istituzioni di diritto civile italiano, vol. I, pp. 38-40).
} 
Diante dessas dificuldades inerentes à matéria, entendemos que as principais críticas a qualquer um desses sistemas deve partir, primeiramente, do objeto para o qual a proteção está direcionada. Vale dizer, se é para os direitos individuais, as relações jurídicas, as situações jurídicas ou os fatos realizados. Somente a partir daí é que se tem elementos para optar pelo melhor sistema a seguir e propor soluções para as lacunas dos doutrinadores dessa corrente.

Nesse sentido alguns doutrinadores apontam uma incoerência no sistema de proteção conferido às situações jurídicas contratuais por ROUBIER. Segundo afirmam, ao alargar por demais o espectro de situações que ficariam a salvo da eficácia imediata da lei, o Professor da Faculdade de Direito de Lyon acabou por se distanciar da análise objetiva do modo como uma lei atinge uma determinada situação jurídica em curso, trazendo para o sistema de direito intertemporal elemento alusivo à natureza das relações ou situações atingidas $^{135}$.

De fato, parece-nos pouco convincente a explicação de que para as situações jurídicas contratuais o fundamento da regra da sobrevivência da lei antiga seja a diversidade. Em verdade o que se está protegendo é a vontade dos contratantes e a possibilidade deles disporem sobre suas esferas de direitos. Talvez ROUBIER não pudesse admiti-lo para não vincular seu sistema de direito intertemporal com a proteção de direitos subjetivos, mas, de outro lado, não poderia deixar de afastar a aplicação imediata da lei para essas hipóteses, para não criar um sistema que relegasse as situações contratuais a uma posição de insegurança muito grande.

Não pretendemos ir além com a análise das críticas formuladas à teoria de ROUBIER como, por outro lado, também não fizemos com a teoria de GABBA, porque, conforme demonstraremos no tópico seguinte, nosso sistema conta com elementos das duas correntes. Assim, parece-nos pouco proveitoso para os fins do presente trabalho um aprofundamento nas defesas de

${ }^{135}$ FÁBIO PESSOA, Elementos para uma teoria..., pp. 49-50. 
cada uma das correntes, se nossa intenção não é sugerir um sistema novo de direito intertemporal, mas organizar e explicar o funcionamento dos principais institutos do sistema de direito processual intertemporal civil brasileiro, tal qual está previsto no nosso ordenamento.

\subsection{Pontos de contato entre as duas correntes}

Em linhas gerais pode-se resumir o sistema de GABBA da seguinte maneira: (i) a lei jamais deve atingir os facta praeterita; (ii) a lei não deve ferir direitos adquiridos dos participantes de uma relação; e (iii) o limite para a não retroatividade da lei são os direitos adquiridos (entendendo-se a retroatividade como um modo de atingir relações jurídicas constituídas antes do seu advento).

Já o resumo do pensamento de ROUBIER aponta para essas diretrizes: (i) a lei jamais deve ser retroativa, de modo que não se aplica aos facta praeterita, e quanto aos facta pendentia não pode atingir seus efeitos anteriores nem os seus momentos de constituição e extinção; (ii) para as situações jurídicas legais a regra geral é a eficácia imediata da lei anterior; e (iii) para as situações jurídicas contratuais a regra geral é a sobrevivência da lei antiga.

Nota-se daí que, em termos práticos as duas correntes chegam a resultados muito parecidos para grande parte dos casos em que surgem problemas de direito intertemporal ${ }^{136}$.

Primeiramente, porque em ambas os facta praeterita estão imunizados contra ataques do legislador. Em segundo lugar, uma gama enorme

\footnotetext{
${ }^{136}$ CARLOS MAXIMILIANO, Direito intertemporal..., p. 9, logo após esclarecer as diferenças entre as correntes subjetiva e objetiva do direito intertemporal pontifica que: "Uma sobreleva à outra, quanto à propriedade das expressões; porém, na prática, o dissídio se reduz a proporções mínimas. Assim resulta, porque, em verdade, o respeito pelas situações jurídicas definitivamente constituídas importa em abstenção de aplicar os textos positivos retroativamente".
} 
de direitos subjetivos encontra-se protegida na teoria de ROUBIER, quando ele admite a sobrevivência da lei antiga para as situações jurídicas contratuais.

Outra coincidência de tratamento poderá ser verificada nos casos em que uma situação jurídica legal não gere direitos adquiridos aos seus participantes. Em tais hipóteses, tanto para o mestre italiano como para o francês a lei deverá ter eficácia imediata. A única diferença será de ordem terminológica já que GABBA qualificou o fenômeno de retroatividade justa e ROUBIER de eficácia imediata. ${ }^{137}$

As diferenças podem ser encontradas tanto nos casos em que o conceito de direito adquirido não abarque determinadas situações jurídicas, em função do conteúdo que se dê aos direitos passíveis de aquisição, como naqueles em que os efeitos futuros de um direito adquirido possam ser considerados como parte integrante desses.

Exemplo clássico da primeira hipótese é a capacidade civil. Imaginemos a hipótese de uma lei que aumente a idade da maioridade de 18 para 21 anos. No momento em que a lei entrar em vigor, como ficará a situação dos maiores de 18 anos e menores de 21? Antes da vigência da lei eles eram maiores, após, em tese, seriam menores.

$\mathrm{Na}$ teoria dos direitos adquiridos a resposta passa pela possibilidade ou não da maioridade ser entendida como um direito passível de aquisição. Para GABBA a resposta seria positiva ${ }^{138}$, considerando-se como adquirido tal direito, mas, para outros autores adeptos da teoria subjetivista a

\footnotetext{
${ }^{137}$ A propósito das semelhanças entre ambas as correntes convém transcrever os ensinamentos de SERPA LOPES, Comentário teórico e prático da Lei de Introdução ao Codigo Civil, vol. I, p. 304: "Em muitíssimas aplicações práticas, as duas teorias apenas apresentam uma diferença nominal. Assim, v.g., a teoria subjetiva proclama que todos os direitos públicos ou políticos, no amplo significado da palavra, não constituem direitos adquiridos, ao mesmo tempo que a teoria objetiva diz que as leis relativas aos referidos direitos têm aplicação imediata. A mais poderosa consequência da doutrina objetiva é, ainda, o cancelamento de toda e qualquer referência à distinção entre direitos adquiridos e espectativas. Mas, na quebra desse padrão clássico, há apenas uma transformação de vestes, pois o próprio conceito de situação jurídica envolve por exclusão o de espectativa”.

${ }^{138}$ Teoria della retroattività delle leggi, vol. 2, pp. 65-76.
} 
resposta seria negativa, por considerarem que a capacidade civil não é passível de aquisição ${ }^{139}$.

Já na doutrina de ROUBIER, deve-se considerar que a situação jurídica da maioridade havia sido completada antes do início da vigência da lei. Ademais, a lei nova refere-se a um momento dinâmico dessa situação, já que regula o modo de constituição da maioridade (altera o seu requisito fundamental). Uma vez que ela tem o potencial de atingir esse momento dinâmico da situação jurídica, não poderá alterar a situação de maioridade daqueles que já tivessem completado 18 anos antes da entrada em vigor da nova lei, sem que seja retroativa ${ }^{140}$.

Para exemplificar a segunda hipótese podemos pensar na ordem de prioridade de determinado crédito que não tenha natureza contratual. Esse grau de prioridade no concurso com outros credores é um efeito indireto da obrigação $^{141}$. Na teoria de GABBA, esse efeito da obrigação não poderá ser alterado por lei posterior, devendo ser compreendido conjuntamente com o direito adquirido ao adimplemento da obrigação ${ }^{142}$. Aplicando-se a teoria de ROUBIER, veremos que os efeitos ulteriores de uma situação jurídica legal não estão protegidos contra a eficácia imediata da lei, sendo, portanto, possível suas alterações pela nova lei, sem que haja aí qualquer retroatividade ${ }^{143}$.

\footnotetext{
${ }^{139}$ Esse é o entendimento de DEMOLOMBE, Cours de code de Napoleon, vol. I, pp. 50-52.

${ }^{140}$ Le droit transitoire, p. 194.

${ }^{141}$ GABBA, Teoria della retroattività..., vol. 4, p. 129.

${ }^{142}$ Teoria della retroattività..., vol. 4, p. 128-129. Às fls. 3 desse volume o mestre italiano assevera que: "Tutta quanta la dottrina della retroattività delle leggi intorno alle obbligazioni riposa sul principio, che della validità, del contenuto, e degli effetti delle obbligazioni e dei contratti, si deve decidere secondo la legge vigente nel giorno in cui i medesimi vennero posti in essere”.

${ }^{143}$ FÁBIO PESSOA parece não vislumbrar a hipótese em que a teoria clássica ofereça uma proteção mais ampla do que a objetivista. Para o autor, "o reconhecimento de hipótese de violação ao direito adquirido inevitavelmente redundará na admissão de indevida afetação de uma situação jurídica constituída; não necessariamente, todavia, a identificação do caráter retroativo da lei à luz da teoria objetivista permitirá que se vislumbre, em todo e qualquer caso, desrespeito a direito adquirido" (Elementos para uma teoria..., 46). Esse pensamento não se coaduna com as lições de ROUBIER que chegou a afirmar taxativamente que “Le système de l'effet immédiat de la loi, dans le premier cas (casos de situações jurídicas que se formam num intervalo de tempo, ou mediante a prática de mais de um ato), n'a guère été discuté; au contraire, en ce qui concerne les situations juridiques en cours d'effet, des résistances très fortes ont été opposées, dans la doctrine des droits acquis" (Le droit transitoire, p. 293). Um pouco mais adiante (p. 319) o autor se posiciona sobre o exemplo que citamos, asseverando que "Les lois que établissent des privilèges au profit de certaines créances doivent être rgées encore dans le même groupe. (...) Les lois nouvelles, en pareil cas, sont relatives aux effets de la créance dans la procédure de distribuition de l'actif du débiteur. Ces lois recoivent effet immédiat, c'est-à-dire qu'elles s'appliquent à tous les règlements de créanciers postérieurs".
} 


\section{Capítulo IV - O direito intertemporal no ordenamento jurídico brasileiro}

\subsection{Os diversos sistemas de direito intertemporal}

Antes de analisarmos o modo como o direito intertemporal está regulamentado em nosso ordenamento entendemos ser conveniente traçar as linhas gerais das diferentes formas com que os demais sistemas jurídicos cuidam da questão.

Apesar de ser uma constante nos ordenamentos jurídicos do mundo civilizado $^{144}$, a proteção contra a retroatividade das leis é tratada de maneira bastante diferenciada ao redor do globo.

A primeira distinção fundamental diz respeito à hierarquia das leis que regem a matéria ${ }^{145}$. Existem países que, a exemplo do Brasil, dão tratamento constitucional aos institutos de direito intertemporal a fim de conferirIhes maior rigidez, impedindo que o legislador ordinário possa criar leis retroativas ou ofensivas ao direito adquirido. A nação pioneira desse grupo são os Estados Unidos da América ${ }^{146}$.

\footnotetext{
${ }^{144}$ LIMONGI FRANÇA, A irretroatividade das leis..., p. 9 enumera os seguintes passos que as sociedades tiveram que dar para que o direito intertemporal chegasse ao estágio em que se encontra: "Primeiramente, foi preciso que as sociedades políticas (de incipiente conspecto) passassem do estado de fato para o estado de direito; que, em meio ao direito consuetudinário, se fosse afirmando o direito escrito: que, no recesso dos preceitos ético-religiosos (fas) se fossem definindo as regras propriamente jurídicas (jus); que tivesse surgido a noção da linha divisória entre o império da lei nova e o da lei antiga e, pois, da revogação de uma lei por outra”.

${ }^{145}$ Após anotar que a irretroatividade não se impõe de forma automática e inexorável ao legislador, podendo, em tese, ser contrariada por ele, a não ser que haja uma restrição expressa à atividade legislativa inserida na Constituição, anota FABIO TABOSA PESSOA, Elementos para uma teoria..., p. 19, que: “justamente nesse particular se estabelece, sob um prisma amplo, a diferença de orientação adotada pelos diversos países, dentre duas possibilidades: quando se pretende levar a regra da irretroatividade à condição de garantia fundamental dos cidadãos e evitar desde logo a edição de diplomas dotados desse efeito, o princípio vem insculpido na Constituição, e se dirige nesse caso, antes de mais nada, ao legislador, secundariamente ao juiz, aplicador da lei; eventual edição de diploma retroativo, afrontando os termos em que definida a garantia, será assim, em princípio, desde logo marcada pela eiva de inconstitucionalidade, para cuja declaração bastará, com abstração de qualquer critério de oportunidade, a constatação objetiva da infringência pelo legislador ordinário ao comando da lei hierarquicamente superior”.

146 Outra nação que trata do direito intertemporal no corpo da Constituição é Portugal. O Art. $18^{\circ}$ da Constituição da República Portuguesa ao dispor sobre a 'força jurídica' das normas estabelece: “1. Os
} 
Nesses países a garantia contra a retroatividade da lei atinge um grau extremamente elevado ${ }^{147}$, sendo admissível apenas em casos em que haja um choque de princípios contra valores também consagrados no corpo da constituição ${ }^{148}$.

De outra parte, não são poucas as nações que relegam o tratamento da matéria ao legislador ordinário, deixando, assim, de criar regras constitucionais sobre o tema, a exemplo da França e Itália ${ }^{149}$.

Deve-se ressaltar, contudo, que mesmo nos países em que o direito intertemporal vem regulamentado por leis ordinárias, existe muita controvérsia acerca dos limites conferidos ao legislador para editar leis retroativas, dado que a noção de irretroatividade das leis é muitas vezes entendida como um princípio geral de direito que deve ser observado pelo

preceitos constitucionais respeitantes aos direitos, liberdades e garantias são diretamente aplicáveis e vinculam as entidades públicas e privadas. 2. A lei só pode restringir os direitos, liberdades e garantias nos casos expressamente previstos na Constituição, devendo as restrições limitar-se ao necessário para salvaguardar outros direitos ou interesses constitucionalmente protegidos. 3. As leis restritivas de direitos, liberdades e garantias têm de revestir carácter geral e abstracto e não podem ter efeito retroactivo nem diminuir a extensão e o alcance do conteúdo essencial dos preceitos constitucionais”.

${ }^{147}$ CAIO MÁRIO DA SILVA PEREIREA, Instituições de direito civil, vol I, pp. 140-147, após dividir os sistemas existentes de direitos intertemporal em três categorias, a saber: (a) sistemas que não tratam da matéria; (b) que a regulam por legislação ordinária e, (c) que conferem tratamento constitucional a ela, mostra-se adepto desse último, asseverando que: "De todos os sistemas o que para nós mais sólidas bases encontra é o da constitucionalização do princípio da não-retroatividade, sem embargo da opinião contrária de Cunha Gonçalves, que não enxerga solidez em tal estrutura, antes nela vê a oportunidade de ser o preceito da Constituição ferido pelo legislador, quando se torna necessário à segurança da ordem jurídica imprimir efeito retroativo a uma lei. Se no campo abstrato este é o sentido natural da norma jurídica, e se a estabilidade social medra à sua sombra, admitir, como regra ou como exceção, a retroatividade da lei, implica negar substancialmente aquilo que o direito proclama como conceito puro. Já que a retroatividade da lei é condenada pelo pensamento jurídico universal, melhor será, então, que fique em definitivo interdita."

${ }^{148}$ Apesar da teoria de SAVIGNY não ter sido adotada em sua essência em nenhum ordenamento, existe ali um elemento que deve ser considerado para fins de limitação da manutenção dos direitos adquiridos. Trata-se dos casos em que determinada categoria de direito é suprimida do ordenamento, tornando-se contrário aos seus valores fundamentais, como é o caso clássico da escravidão em que, uma vez abolida, tornou-se contrária aos valores aceitos à época, e os proprietários de escravos perderam o direito de propriedade que detinham sobre seus escravos (Sistema.., vol VIII, pp. 396-401). Devemos frisar que o romanista alemão não fez a ressalva sobre a necessidade da supressão da categoria de direitos (instituto) gerar uma afronta aos valores fundamentais protegidos pelo sistema para que se pudesse permitir que a nova lei ferisse direitos adquiridos, o que ocasiona uma amplitude muito grande dos casos em que esse fenômeno pode ocorrer.

149 ROUBIER chegou a indagar se a inclusão da regra da irretroatividade não seria mais vantajosa, mas concluiu com apoio na doutrina de seu país que a elevação dessa regra a nível constitucional poderia ser inconveniente porque, em certos casos excepcionais o legislador precisa ter liberdade para criar normas retroativas (Le droit transitoire, p. 224-225). 
legislador $^{150}$. De qualquer sorte, nos casos em que se admite a retroatividade das leis, ela deve ter previsão expressa, jamais sendo presumível.

Existem, ainda, países que não detêm regras gerais de direito intertemporal quer em sua constituição como em leis ordinárias, como é o caso da Alemanha. Isso não significa, contudo, que não haja regulamentação da disciplina ou que ela esteja totalmente relegada a princípios não escritos. O mais comum nessas nações é que as leis sejam dotadas de disposições transitórias para esclarecer o modo como serão regulados os fatos pendentes que por ela serão atingidos. Cada norma detém a sua própria regra de direito transitório e, com isso, o sistema desses países prescinde de regras gerais sobre a matéria ${ }^{151}$.

Além da hierarquia e da existência ou não de disposições gerais de direito intertemporal, outra diferença marcante sobre o modo como a matéria vem regulada nos diversos países diz respeito ao conteúdo da proteção de direito intertemporal.

Nas nações mais influenciadas pela teoria clássica existe a previsão expressa da proteção aos direitos adquiridos, enquanto que nos ordenamentos inspirados pela doutrina objetivista a proteção é contra a retroatividade da lei, adotando-se para efeito de compreensão desse conceito um critério objetivo (fatos consumados, relações jurídicas ou situações jurídicas).

Não se pode deixar de notar que alguns sistemas adotam proteção mista, ou seja, prevêem expressamente que a lei terá eficácia imediata e

\footnotetext{
${ }^{150}$ Nesse sentido, afirma WASHINGTON DE BARROS MONTEIRO, Curso de direito civil, $1^{\circ}$ volume, $\mathrm{p}$. 30, que o princípio da irretroatividade das leis "chegou outrora a ser considerado de direito natural, correspondente a uma justiça superior. BARTOLO não hesitou em dizer que, embora com preceito expresso em contrário, não podiam as leis projetar seus efeitos no passado. WALKER, citado por BARBALHO, afirmava que leis retroativas só tiranos as fazem e só escravos se lhes submetem. A retroatividade, proclamou-o BENJAMIN CONSTANT, arrebata à lei o seu caráter; lei que retroage não é lei". Para uma visão ampla dessa polêmica na literatura européia, v. LIMONGI FRANÇA, A irretroatividade das leis... , pp.. 184-189, esp . pp. 185-186.

${ }^{151}$ RUGGIERO, Instituições..., vol. I, p. 224, nota 18, elogia a postura adotada pelo legislador alemão, ao entendimento de que as regras gerais são insuficientes e ambíguas. Ponto de vista oposto foi adotado por ROUBIER, que afirmou ser muito mais vantajoso que a solução dos conflitos de leis no tempo parta de princípios gerais sobre a matéria, dado que a solução individualizada em cada norma parte de um método indutivo que não é suscetível de proporcionar ao intérprete nenhum esclarecimento suplementar (Le droit transitoire, pp. 151-156).
} 
afirmam que ela não poderá ofender direitos adquiridos. Por outro lado, mesmo em países em que a proteção dirige-se exclusivamente contra a retroatividade da lei, o conteúdo dessa será conferido pela doutrina e jurisprudência, o que permite, muitas vezes, que a proteção se dirija aos direitos adquiridos mesmo que não haja norma expressa tratando desse instituto ${ }^{152}$.

Por fim, existem ordenamentos que, como o nosso, imunizam não só os direitos adquiridos contra alterações legislativas futuras como também o ato jurídico perfeito e a coisa julgada.

Em linhas gerais podemos resumir as diferenças de tratamento da disciplina em função (a) da hierarquia das normas que regem a matéria; (b) da existência ou não de regras gerais sobre ela; e, (c) do conteúdo da proteção conferida.

\subsection{Evolução histórica do tratamento da matéria no ordenamento brasileiro}

O desenvolvimento do direito intertemporal no nosso ordenamento merece ser analisado sob dois ângulos distintos, a saber, do modo como a matéria foi tratada em nossas diversas constituições e das diferentes redações conferidas à Lei de Introdução ao Código Civil. Por uma questão de hierarquia, estudaremos primeiramente a evolução da matéria em nível constitucional para depois analisar as alterações da legislação ordinária, momento em que já teremos elementos para confrontá-la com o texto constitucional em vigor quando de sua promulgação a fim de compreender o seu verdadeiro sentido.

\footnotetext{
${ }^{152}$ É bastante ilustrativo o exemplo do sistema francês que do século XIX até o início do século XX era marcado pela influência de autores adeptos da teoria subjetivista, como MERLIN, CHABOT DE L'ALLIER e MEYER. A interpretação que se dava então ao art. $2^{\circ}$ do Código Civil era a de uma norma direcionada à proteção dos direitos adquiridos. Com o passar do tempo e a difusão das idéias objetivistas, grande parte da doutrina e da jurisprudência francesas passaram a compreender que o conteúdo da proteção era voltado exclusivamente contra a retroatividade da lei.
} 
Antes de analisarmos como nosso ordenamento historicamente cuidou do direito intertemporal é relevante registrar que a disciplina escrita e até mesmo detalhada do tema era tradicional no direito português do período da colonização ${ }^{153}$. Notam-se inúmeras passagens nas três ordenações dispondo sobre o direito intertemporal, sem que houvesse uma sistematização adequada do tema, o que se deve tanto ao fato desses diplomas serem anteriores à fase científica da disciplina, como, principalmente ao caráter absolutista que influenciou a confecção das ordenações manoelinas e filipinas ${ }^{154}$.

\subsubsection{O direito intertemporal nas constituições brasileiras}

Com a declaração de independência do Brasil e a promulgação da Constituição de 1.824 iniciou-se o regramento constitucional da matéria, que foi disciplinada nos incisos II e III do art. 179. O caput desse dispositivo dispunha: $A$ inviolabilidade dos direitos civis e politicos dos cidadãos brasileiros, que tem por base a liberdade, a segurança individual e a propriedade, é garantida pela Constituição do Império, pela maneira seguinte. Nos seus incisos II e III lia-se: II. Nenhuma lei será estabelecida sem utilidade publica. III. A sua disposição não terá effeito retroactivo ${ }^{155}$.

Na constituição de 1.891 a matéria foi tratada no art. 11, § $3^{\circ}$, que dispunha: art. 11. É vedado aos Estados como á União: (...) $\S 3^{\circ}$ prescrever leis retroactivas ${ }^{156}$.

\footnotetext{
${ }^{153}$ V. LIMONGI FRANÇA, A irretroatividade das leis..., pp. 89-93.

154 Depois de afirmar que os três sistemas das ordenações eram influenciados pelo Jus Quaesitum como princípio, LIMONGI FRANÇA observa que não havia menção expressa à proteção ao direito adquirido em qualquer texto das ordenações, mas tão somente em algumas leis extravagantes, e conclui que essa proteção direta "não se compadeceria com o espírito monárquico e absolutista que as dominou, principalmente as duas últimas”. Em nota de rodapé o autor esclarece a limitação desse espírito absolutista quanto às duas últimas ordenações, demonstrando que o absolutismo em Portugal somente teve início após o reinado de Afonso V, o que justifica a exclusão das ordenações afonsinas (A irretroatividade das leis..., pp. 93-94).

155 JOSÉ CARLOS RODRIGUES, Constitutição Política do Imperio do Brasil seguida do Acto Addicional, da Lei da sua interpretação e de outras analysada por um jurisconsulto e novamente annotada com as leis regulamentares, decretos, avisos, ordens, e portarias que lhe são relativas.

156 JOÃO BARBALHO U. C., Constituição Federal Brasileira - commentarios.
} 
Nota-se daí uma menção expressa à irretroatividade da lei, mas não devemos nos esquecer das datas em que essas constituições foram promulgadas (1.824 e 1.891). Nesse período dominava a doutrina clássica subjetivista em que o conceito de irretroatividade era confundido com o de proteção ao direito adquirido. Conclui-se, pois, que a limitação constitucional era contra a ofensa a esses direitos e não propriamente contra a retroatividade no sentido que lhe conferiu a doutrina objetivista ${ }^{157}$.

A Constituição de 1.934 foi a primeira a fazer menção expressa à proteção aos direitos adquiridos. Seu art. 113 dispunha que a Constituição assegura a brasileiros e a estrangeiros residentes no paiz a inviolabilidade dos direitos concernentes á liberdade, á subsistencia, á segurança individual e á propriedade nos termos seguintes, e, no n. 3 assegurava a lei não prejudicará o direito adquirido, o acto juridico perfeito e a coisa julgada ${ }^{158}$.

Seguiu-se a ela a Constituição de 1.937, em que, pela primeira e única vez, o sistema de direito intertemporal brasileiro deixou de ser tratado constitucionalmente ${ }^{159}$.

\footnotetext{
${ }^{157}$ Nesse sentido é o comentário do então Ministro do Supremo Tribunal Federal JOÃO BARBALHO, Constituição Federal Brasileira..., p. 62, para quem: "Mas, porquanto a prohibição de leis retroactivas é estabelecida por amor e garantia dos direitos individuaes, não ha motivo para que ella prevaleça em casos nos quaes offensa não lhes é feita e a retroação é proveitosa ao bem geral". Caminha conjuntamente com esse entendimento a lição de CARLOS MAXIMILIANO, Commentarios à Constituição Brasileira, p. 225: "Não se entendeu jámais no Brasil, nem nos Estados Unidos, que o texto constitucional fulminasse com a nullidade absoluta, indistinctamente, todas as leis que tivessem effeito retroactivo. O preceito foi inserto no codigo supremo como uma garantia da liberdade e dos direitos patrimoniaes do individuo. Toda lei que não contrariar esse duplo proposito, prevalecerá na integra, salvo se violar outra disposição fundamental”.

${ }^{158}$ Comentando essa disposição ARAUJO CASTRO reforça que o texto constitucional não trouxe alterações significativas quanto aos anteriores, porque mesmo naqueles a proteção era dirigida aos direitos adquiridos (A nova Constituição Brasileira, p. 353). LIMONGI FRANÇA observa que no período em que foi promulgada essa Constituição já havia na europa fortes oposições à corrente subjetivista, com a publicação dos trabalhos de VAREILLES-SOMMIÈRES, CHIRONI, SIMONCELLI, DUGUIT e AFFOLTER, mas, em virtude da sedimentação secular da idéia de direito adquirido entre nós, não houve à época da promulgação maiores discussões sobre o tema (A irretroatividade das leis..., pp. 126-127).

${ }^{159}$ Apesar de não conter disposição sobre a irretroatividade das leis em texto constitucional, à falta de disposição expressa as leis do período não deveriam ser aplicadas retroativamente. Isso porque, conforme ensina WILSON DE SOUZA CAMPOS BATALHA, Direito intertemporal, p. 437: "Não se poderia inferir do texto constitucional de 1937 que as leis devessem retroagir; apenas, facultou-se ao legislador ordinário, por disposição expressa, conferir retroação às leis que elaborasse. Na falta de expressa determinação neste sentido, incidiria o art. $3^{\circ}$ da antiga Introdução ao Código Civil, inclusive quanto às definições discutíveis constantes de seus parágrafos”. LIMONGI FRANÇA, demonstra que a irretroatividade da lei penal continuou a ter tratamento constitucional pelas previsões contidas nos artigos 13 e 122, inc. 11 dessa Constituição (A irretroatividade das leis..., p. 141).
} 
A Constituição de 1.946 retomou a tradição de elevar o direito intertemporal ao plano constitucional e dispôs em seu art. 141 , § $3^{\circ}$ que a lei não prejudicará o direito adquirido, o ato jurídico perfeito e a coisa julgada. Nota-se uma identidade com a fórmula adotada pela Constituição de 1.934 que é a mesma da nossa atual Constituição (art. 50, inc. XXXVI). De diferente no período pode-se notar um avanço na discussão do alcance desse dispositivo. Inspirada pelas idéias objetivistas em voga na Europa e pelo período em que a disciplina dos direitos adquiridos deixou de ter tratamento constitucional, parte da doutrina começou a enxergar na proteção constitucional uma dupla garantia, quanto à irretroatividade da lei e quanto à proteção dos direitos subjetivos ${ }^{160}$.

A Constituição de 1.967 e a Emenda Constitucional de 1.969 não inovaram no tema, mantendo-se a menção expressa à proteção dos direitos adquiridos, atos jurídicos perfeitos e da coisa julgada. Assim, o art. 149, da primeira estatuía que a Constituição assegura aos brasileiros e estrangeiros residentes no País o direito à vida, à liberdade, ao trabalho e à propriedade nos seguintes termos e, em seu $\S 3^{\circ}$, lia-se a lei não prejudicará o direito adquirido, $o$ ato jurídico perfeito e a coisa julgada. Já a Emenda Constitucional de 1.969 tratou da matéria em seu art. 153, § $3^{\circ}$. Esse parágrafo era uma repetição do contido na Constituição de $1.967^{161}$.

Deixaremos para o momento de traçar o perfil atual do ordenamento jurídico brasileiro a análise do modo como o direito intertemporal foi regulamentado na Constituição de 1.988.

\footnotetext{
${ }^{160}$ Para PONTES DE MIRANDA, Comentários à Constituição de 1.946, tomo IV, pp. 375-376: “É claro, portanto, que o art. 141, $\S 3^{\circ}$, poderia ter dito que a lei nova não incide sôbre o ato jurídico perfeito, referiuse à eficácia dos fatos jurídicos em geral: 'não prejudicará o direito adquirido, o ato jurídico perfeito...' Melhor teria dito: 'não incidirá sôbre os fatos jurídicos pretéritos, inclusive atos jurídicos perfeitos’”.

${ }^{161}$ Analisando o texto dessas constituições LIMONGI FRANÇA apenas observa tratar-se de repetição dos textos de 1.934 e 1.946 (A irretroatividade das leis..., p. 174).
} 


\subsubsection{A Lei de Introdução ao Código Civil e suas alterações}

Logo após nossa independência vivemos um período de transição legislativa, já que não foi imediatamente depois da declaração de independência que nossas leis fundamentais foram promulgadas. Antes da vigência do Código Civil Brasileiro de 1.916 as relações civis eram reguladas pelas ordenações filipinas, por força de lei aprovada pela Assembléia Constituinte de 1.823 que declarava em vigor a legislação pela qual se regia o Brasil até 25 de abril de 1.821 e bem assim as leis promulgadas pelo Senhor D. Pedro, como regente Imperador daquela data em diante, e os Decretos das Cortes Portuguesas que são especificados ${ }^{162}$.

Seguiu-se um período em que renomados juristas foram convidados a elaborar um Anteprojeto de Código Civil, dos quais destaca-se o de COELHO RODRIGUES, que, em matéria de direito intertemporal, foi o que mais influenciou a primeira redação da Lei de Introdução ao Código Civil ${ }^{163}$.

A disciplina referente à eficácia temporal das leis estava contida no art. $5^{\circ}$ desse Anteprojeto que assim dispunha: A lei não pode ter efeito retroativo nem prejudicar os direitos civis adquiridos, os atos jurídicos já perfeitos e a coisa julgada ${ }^{164}$.

Quase um século após a nossa independência veio a lume o Código Civil de 1.916, cuja Lei de Introdução dispunha em seu artigo $3^{\circ}$ que a lei não prejudicará, em caso algum, o direito adquirido, o acto juridico perfeito, ou a coisa julgada. Ao definir tais institutos o legislador pátrio manteve-se fiel ao

\footnotetext{
${ }^{162}$ V. JOSÉ EDUARDO MARTINS CARDOZO, Da retroatividade da lei, pp. 223-224.

${ }^{163}$ Cf. LIMONGI FRANÇA, A irretroatividade das leis..., p. 115 e JOSÉ EDUARDO MARTINS CARDOZO, Da retroatividade..., p. 233.

${ }^{164}$ Nos três parágrafos que se seguiam o Anteprojeto passava a conceituar cada um desses institutos, com a seguinte redação: $\S 1^{\circ}$ consideram-se adquiridos não só os direitos que o titular ou alguém por ele já pode exercer, como aqueles cujo exercício depende do prazo prefixado ou condição preestabelecida e não alterável ao arbítrio de outrem; $\S 2^{\circ}$ Considera-se ato jurídico perfeito o que está concluído na conformidade da lei vigente ao tempo em que foi praticado; $\S 3^{\circ}$ Considera-se cousa julgada a decisão judiciária contra a qual não cabe mais recurso ordinário às respectivas partes. V. LIMONGI FRANÇA, A irretroatividade das leis..., p. 115
} 
conceito de COELHO RODRIGUES no que se refere aos direitos adquiridos, distanciando-se um pouco quanto aos demais. De fato, dos $\S \S 1^{\circ}$ ao $3^{\circ}$ lê-se: $\S 1^{\circ}$ consideram-se adquiridos assim os direitos que o seu titular ou alguem por elle, possa exercer, como aquelles cujo começo de exercicio tenha termo prefixo, ou condição preestabelecida, inalteravel a arbitrio de outrem; $\S 2^{\circ}$ reputa-se acto juridico perfeito o já consummado segundo a lei vigente ao tempo em que se effectuou; $\S 3^{\circ}$ chama-se coisa julgada, ou caso julgado, a decisão judicial, de que já não caiba recurso.

Devemos recordar que nesse período a Constituição vigente era a de 1.891, que não se reportava expressamente aos direitos adquiridos em seu texto, embora a doutrina do período afirmasse essa limitação para o conceito de irretroatividade contido na constituição. A Lei de Introdução ao Código Civil apenas consolidou o entendimento doutrinário a respeito, remarcando que a proteção conferida pelo sistema de direito intertemporal vigente limitava a irretroatividade da lei à não afetação dos direitos adquiridos ${ }^{165}$. Não se pode deixar de notar, por outro lado, a inegável influência que esse texto normativo exerceu sobre as Constituições seguintes (à exceção da de 1.937) que passaram a tratar da matéria de forma quase idêntica à contida no seu caput.

Durante o período do Estado Novo, em que a proteção aos direitos adquiridos não figurava no texto constitucional, o Governo Federal editou o Decreto-Lei $n^{\circ} 4.657$, de 4 de setembro de 1.942 alterando sensivelmente o sistema de direito intertemporal brasileiro. Esse Decreto-Lei, que substituiu a Lei de Introdução ao Código Civil, estabeleceu em seu art. $6^{\circ}$ que: A lei em vigor terá efeito imediato e geral. Não atingirá, entretanto, salvo disposição expressa em contrário, as situações jurídicas definitivamente constituídas e a execução do acto jurídico perfeito.

\footnotetext{
165 Esse é o entendimento de J. M. DE CARVALHO SANTOS, Codigo civil brasileiro interpretado principalmente sobre o ponto de vista pratico, p. 38, que assim comentou o art. $3^{\circ}$ da Lei de Introdução ao Código Civil de 1.916: "Neste artigo nada mais se fez, portanto, que fixar praticamente o conteudo e os limites do principio constitucional, firmando-se que retroactivas são reputadas apenas as leis que prejudicarem direitos adquiridos, actos juridicos perfeitos ou casos julgados”.
} 
Nota-se daí um abandono da doutrina clássica dos direitos adquiridos e uma aproximação com a teoria objetivista de ROUBIER, não só pela menção expressa às situações jurídicas que são o centro da doutrina do mestre francês, como pela aplicação do princípio da eficácia imediata da lei ${ }^{166}$.

Tendo sido elaborado em um período em que o direito intertemporal civil não estava disciplinado em nível constitucional, o Decreto-Lei facultou ao legislador ordinário a possibilidade de atingir situações jurídicas constituídas, bem como a execução do ato jurídico perfeito, ao asseverar que a lei não deveria atingi-los salvo disposição em contrário.

Pouco tempo depois foi promulgada a Constituição de 1.946 em que o constituinte retornou à tradição de conferir proteção aos direitos adquiridos, ao ato jurídico perfeito e à coisa julgada. O texto da Lei de Introdução ficou 'defasado' em termos de alinhamento com a corrente subjetivista que orientava a norma constitucional e alguns autores começaram a contestar sua constitucionalidade $^{167}$. Para solucionar o problema o legislador alterou a redação do art. $6^{\circ}$, por meio da Lei 3.238 , de $1^{\circ}$ de agosto de 1.957 , conferindo-lhe a redação atual, em que resta afirmado no caput que a lei em vigor terá efeito imediato e geral, respeitados o ato jurídico perfeito, o direito adquirido e a coisa julgada.

Vê-se que a norma não se restringiu a proteger os direitos adquiridos, o ato jurídico perfeito e a coisa julgada, tendo afirmado a eficácia imediata e geral da lei, pela qual se identifica um traço das doutrinas objetivistas, especialmente a de PAUL ROUBIER. Diante dessa mistura de correntes, parte da doutrina passou a entender que a proteção contra a retroatividade da lei no sistema jurídico brasileiro não se limita à proteção dos direitos adquiridos, do ato jurídico perfeito e da coisa julgada, mas vai além e impede que a lei atinja

\footnotetext{
${ }^{166}$ Para OSCAR TENÓRIO, o art. $6^{\circ}$ da LICC passou a aceitar o critério defendido pelas teorias objetivas. O autor advertiu, contudo, "que o dispositivo do nosso direito - 'as situações jurídicas definitivamente constituídas' - não se integra, totalmente, no campo de qualquer doutrina” (Lei de Introdução ao Codigo Civil Brasileiro comentada, pp. 112-113)

${ }^{167}$ V. JOSÉ EDUARDO MARTINS CARDOZO, Da retroatividade..., pp. 241-242 e WILSON DE SOUZA CAMPOS BATALHA, Lei de Introdução ao Código Civil, vol. II, tomo I, p. 6.
} 
situações jurídicas anteriormente constituídas $^{168}$ que não se encaixem em qualquer um daqueles conceitos ${ }^{169}$.

A partir de então estavam colocadas as bases fundamentais sobre as quais a doutrina passou a estudar o sistema de direito intertemporal civil brasileiro. Além do alcance do conceito de direito adquirido, as principais discussões giram em torno do alcance da noção de irretroatividade da lei em nosso sistema, bem como da existência ou não de vedação para que o legislador ordinário edite normas retroativas (que não atinjam as garantias expressamente previstas na constituição). Deixaremos para nos aprofundar sobre essas discussões no próximo tópico em que procuraremos traçar as linhas gerais do nosso sistema de direito intertemporal.

Antes de completar o histórico da evolução da Lei de Introdução ao Código Civil, importa registrar que houve por parte do Professor HAROLDO VALLADÃO a elaboração de um Anteprojeto de Lei Geral de Aplicação das Normas Jurídicas, que trazia algumas alterações ao tratamento do direito intertemporal ${ }^{170}$. Esse Anteprojeto não chegou a ser aprovado, mas vem sendo louvado por parte da doutrina em função da excelência no tratamento da matéria $^{171}$.

Sua exposição de motivos traz uma explicação muito relevante sobre a fórmula contida no caput do art. $6^{\circ}$ da LICC ao Código Civil, já que o art. 81 do Anteprojeto também afirmava a eficácia imediata da lei nova ${ }^{172}$,

\footnotetext{
${ }^{168}$ Para ser mais exato, suas fases dinâmicas ou os efeitos anteriormente praticados.

${ }^{169}$ WILSON DE SOUZA CAMPOS BATALHA, Lei de Introdução..., vol. II, tomo I, admite que a redação do art. $6^{\circ}$ da LICC misturou as soluções das teorias subjetivista e objetivista, mas critica o legislador por não ter atentado para as ressalvas doutrinárias sobre essa estranha simbiose (p. 6).

${ }^{170} \mathrm{O}$ direito intertemporal foi regulado nos artigos 81 a 85 desse Anteprojeto e, em linhas gerais, seguia a tradição brasileira de proteção aos direitos adquiridos, com a manutenção da regra de eficácia imediata da lei prevista na LICC. As diferenças fundamentais eram notadas no tratamento explícito de determinadas matérias que mais comumente geravam polêmica na doutrina, como os prazos em curso, a maioridade, a forma dos atos, a convalidação de vício por lei que eliminasse determinada exigência formal etc.. No art. 85 o Anteprojeto trazia um regramento próprio para algumas questões de direito intertemporal processual. Retornaremos ao ponto quando adentrarmos no assunto.

${ }^{171}$ LIMONGI FRANÇA, A irretroatividade das leis..., p. 171 e JOSÉ EDUARDO MARTINS CARDOZO, Da retroatividade..., pp. 243-244.

${ }^{172} \mathrm{Na}$ realidade o dispositivo falava em aplicação imediata e não eficácia, o que é uma questão apenas de vocabulário que não traz alterações práticas. Eis a redação do caput do art. 81 do Anteprojeto: A lei nova terá
} 
com respeito aos direitos adquiridos, ao ato jurídico perfeito e à coisa julgada. Após pontificar que, com a proteção a esses direitos o Anteprojeto "mantém a tradicional fórmula brasileira constitucional e legal"173, seu autor esclarece, com relação a aplicação imediata da lei nova, que "a regra geral da aplicação imediata da lei nova atende ao próprio imperativo constitucional e legal anterior (Introd., art. $3^{\circ}$, princípio) que apenas estabeleceram exceções, restrições, à aplicação da referida lei. E está coerente com o espírito de nosso tempo, de grandes reformas no campo do direito vigente"174.

De tais explicações nota-se a compatibilidade da fórmula mista prevista na LICC, que não vai de encontro ao texto constitucional e apenas confere uma proteção mais ampla do que a contida na Constituição.

\subsection{Perfil atual do direito intertemporal no ordenamento jurídico brasileiro}

Seguindo longa tradição que, como visto, data dos primórdios do constitucionalismo brasileiro, o constituinte de 1.988 optou por conferir status constitucional ao direito intertemporal.

Das normas constitucionais que regem a matéria merece destaque, por ser aplicável a qualquer campo do direito, o art. $5^{\circ}$, inc. XXXVI, 0 qual assegura que a lei não prejudicará o direito adquirido, o ato jurídico perfeito e a coisa julgada.

Em matéria penal estabelece o inciso XXXIX, do art. $5^{\circ}$, que não há crime sem lei anterior que o defina, nem pena sem prévia cominação

aplicação imediata, não podendo, todavia, prejudicar o direito adquirido, o ato jurídico perfeito e a coisa julgada (C. fed., art. 141, \& $3^{\circ}$ ).

${ }_{173}^{17 e i}$ Geral de Aplicação das Normas Jurídicas, p. 122.

${ }^{174}$ Lei Geral de Aplicação das Normas Jurídicas, p. 122. 
legal ${ }^{175}$ e o inciso XL estatui que a lei penal não retroagirá, salvo para beneficiar o réu.

No campo tributário pode-se mencionar o art. 150, III, alíneas 'a', 'b' e 'c', que, além de impossibilitar a retroação da lei tributária a fatos ocorridos antes de sua vigência (alínea 'a'), ainda limita a eficácia da lei tributária que crie ou aumente tributos para o exercício seguinte da sua entrada em vigor (alíneas 'b' e 'c') ${ }^{176}$.

Não se pode deixar de mencionar - ainda que não sejam normas de caráter geral - a existência de inúmeros dispositivos constitucionais de direito transitório que regulamentam de maneira específica o modo como alguns fatos jurídicos pendentes são atingidos pelas disposições constitucionais no momento de sua entrada em vigor ${ }^{177}$.

Em caráter infraconstitucional as principais regras gerais que regulamentam a matéria estão previstas nos artigos $1^{\circ}, 2^{\circ}$ e $6^{\circ}$ da Lei de Introdução ao Código Civil.

$\mathrm{O}$ art. $1^{\circ}$ trata do período de vacatio legis. Estabelece que, salvo disposição em contrário, a lei começa a vigorar 45 dias após a sua publicação. Em seus parágrafos o dispositivo dita regras sobre situações específicas de vigência da lei.

\footnotetext{
${ }^{175} \mathrm{O}$ dispositivo em questão pode ser entendido como uma dúplice garantia, porque assegura os princípios da irretroatividade da lei penal e da legalidade. Nesse sentido são os comentários de BASILEU GARCIA, Instituições de direito penal, vol. I, tomo I, p. 156, a propósito da regra contida no art. $1^{\circ}$ do Código Penal de 1.940, repetida no Código atual e no dispositivo constitucional acima transcrito: "É evidente que nesse dispositivo se consubstancia o princípio nullum crimen, nulla poena sine lege. No mesmo artigo está implícita a regra geral da irretroatividade das leis penais. Mediante a aplicação retroativa de uma lei penal, dar-se-ia a punição sem prévia lei. Ter-se-ia, ao contrário do que adverte o art. $1^{\circ}$ na sua indicação marginal, a anterioridade do fato à lei, e não a anterioridade da lei ao fato".

176 As normas em questão prevêem os princípios da irretroatividade e da anterioridade, conforme leciona ALIOMAR BALEEIRO, Direito tributário brasileiro, p. 664.

${ }^{177}$ Utilizamos o verbo no tempo presente do indicativo, porque, embora nossa Constituição Federal date de mais de vinte anos, ela está em constante processo de alteração pela promulgação de novas Emendas à Constituição. Atualmente temos 56 Emendas e o Ato das Disposições Constitucionais Transitórias conta com 95 artigos.
} 
Já 0 art. $2^{\circ}$ dispõe sobre o término de vigência das leis. $\mathrm{O}$ caput desse artigo estatui que não se destinando à vigência temporária, a lei terá vigência até que outra a modifique ou revogue, e os seus três parágrafos dão contornos explicativos ao modo de aplicação da regra prevista no caput ${ }^{178}$.

O art. $6^{\circ}$, por sua vez, é a principal regra sobre o conflito de leis no tempo propriamente dito, e estabelece que a lei em vigor terá efeito imediato e geral, respeitados o ato jurídico perfeito, o direito adquirido e a coisa julgada. Ditada a regra geral no caput do artigo, passou o legislador a conceituar cada um desses institutos nos três parágrafos que lhe seguem, sendo, no mínimo, questionável esse esforço para estabelecer tais conceitos, especialmente no que diz respeito ao de coisa julgada que se distancia bastante do verdadeiro conteúdo que the foi conferido pela doutrina processual ${ }^{179}$.

De início é possível verificar que nosso sistema é bastante eclético em matéria de direito intertemporal. Confere tratamento legal e constitucional à matéria, dita regras gerais e transitórias, faz referência ao princípio da irretroatividade (art. $6^{\circ}$, caput, da LICC) e aos direitos adquiridos, adotando, assim, as orientações das correntes objetivista e subjetivista e, para completar, do ponto de vista subjetivo afirma não só a proteção aos direitos adquiridos como também ao ato jurídico perfeito e à coisa julgada.

A primeira questão que surge ao se analisar o modo como a matéria está regrada em nosso ordenamento diz respeito à amplitude da garantia contida no art. 5o, inc. XXXVI, da Constituição Federal.

\footnotetext{
${ }^{178}$ No tópico 2.1. deste estudo afirmamos ser relevante para o estudo do direito intertemporal o plano da eficácia das leis, o que poderia soar contraditório com a colocação dos artigos que tratam de sua vigência entre as normas gerais da matéria. Contudo, quando fizemos aquela observação estávamos nos referindo mais especificamente aos problemas de direito intertemporal e de conflitos de leis, que são realmente mais comuns no plano da eficácia. Isso não quer dizer, todavia, que a matéria afeta à vigência das leis não possa ser colocada dentro da disciplina do direito intertemporal.

${ }^{179}$ De fato, o conceito contido na Lei de Introdução trata por coisa julgada a decisão transitada em julgado, distanciando-se bastante da doutrina majoritária que trata a coisa julgada como qualidade do comando da sentença (BARBOSA MOREIRA, "coisa julgada e declaração, p. 89) e de seus efeitos (LIEBMAN, Eficácia e autoridade da sentença e outros escritos sobre a coisa julgada, pp. 38-57, esp. 41).
} 
Nota-se que nesse dispositivo, diferentemente da regra contida no art. $6^{\circ}$ da Lei de Introdução ao Código Civil, o constituinte apenas menciona a proteção aos institutos do direito adquirido, da coisa julgada e do ato jurídico perfeito, nada dizendo com relação à irretroatividade ou à aplicação imediata da lei.

A dúvida que surge é se o constituinte disse menos do que queria dizer e a proteção contra a retroatividade também está contida como um princípio implícito da Constituição, ou, se a limitação do legislador ordinário diz respeito tão somente aos institutos previstos no inciso XXXVI da Carta Magna. Nessa última hipótese, o legislador ordinário não estaria impedido de criar leis retroativas, desde que respeitasse os direitos adquiridos, o ato jurídico perfeito e a coisa julgada $^{180}$.

Entendemos que essa segunda alternativa é a correta pelos seguintes motivos.

Primeiramente, em que pese ser plenamente aceitável a tese de que o princípio da irretroatividade das leis é um corolário do Estado Democrático de Direito ${ }^{181}$, por ser uma decorrência natural do princípio da segurança jurídica, parece-nos que a proteção aos direitos adquiridos já é suficiente em si para garantir o que de principal existe no afirmado princípio da irretroatividade das leis.

A retroatividade da lei que não venha a ferir direitos adquiridos não causa um estado de insegurança a ponto de permitir que seja

\footnotetext{
${ }^{180}$ Como exemplo podemos citar uma lei que altere a maioridade ou casse a cidadania de estrangeiros provenientes de um país com o qual não haja mais relações diplomáticas. A depender da amplitude que se confira aos 'direitos passíveis de aquisição', a lei que os restringir não ferirá direitos adquiridos. Contudo, ao alterar a constituição de uma situação jurídica será ela retroativa, segundo a concepção de ROUBIER.

${ }^{181}$ MARIA LUIZA VIANNA PESSOA DE MENDONÇA, O princípio constitucional da irretroatividade da lei, pp. 64-66, analisando o princípio da irretroatividade da lei no sistema constitucional de regras $e$ princípios com base nos ensinamentos de CANOTILHO, conclui que "dentro da tipologia dos princípios de direito constitucional, o princípio da irretroatividade da lei apresenta-se como um princípio-garantia; dentro do sistema interno de regras e princípios no campo do direito constitucional, o citado princípio da irretroatividade da lei coloca-se como um princípio especial, concretizando ou densificando os princípios da proteção da confiança e da segurança jurídica, estes, por sua vez, constituindo princípios gerais fundamentais, que densificam o princípio do Estado de Direito".
} 
entendida como um princípio implícito na Constituição Federal ${ }^{182}$. Deveras, a segurança jurídica é a base da teoria subjetivista do direito intertemporal que, em suas linhas mestras, admite a retroatividade da lei desde que (i) venha expressamente prevista e (ii) não fira direitos adquiridos.

Por outro lado, a interpretação sistemática da Constituição leva a crer que o constituinte não disse menos do que queria dizer, haja vista que no inciso $X L$, do art. $5^{\circ}$, ele expressamente menciona a irretroatividade da lei em matéria penal, salvo nos casos em que a retroatividade vier a beneficiar o réu. Quisesse ele estender essa regra para todas as leis não precisaria afirmá-la de maneira específica para a lei penal, donde se conclui que se ele fez a restrição expressamente para tal categoria de leis é porque não quis ampliá-la para as demais.

Mas, apesar de não ter status constitucional, não se pode deixar de negar a importância da irretroatividade como norma de orientação interpretativa, que confere um caminho seguro para o intérprete e aplicador: a irretroatividade é a regra. Sendo exceção, a retroatividade deve ser expressa ${ }^{183}$. Tal é o conteúdo do princípio da irretroatividade ${ }^{184}$ que, apesar de não ser constitucional, é extremamente relevante para o nosso ordenamento.

\footnotetext{
182 Esse raciocínio não se aplica em matéria tributária já que, como visto acima, a Constituição Federal contém regra específica a respeito da irretroatividade da lei que crie ou aumente tributos. Comentando a regra contida no art. 150, inc. III, 'a', da Constituição Federal, observa CLEIDE PREVITALLI CAIS, O processo tributário, p. 66, que: "Esse comando leva à conclusão de que ao princípio da irretroatividade, contido no inc. XXXVI do art. $5^{\circ}$ da CF, foi incluído outro conceito, de âmbito maior e dirigido à matéria tributária. De fato, se a lei pode retroagir, embora não deva, respeitando-se, porém, o ato jurídico perfeito, a coisa julgada e o direito adquirido, em senda tributária, é forçoso concluir que a lei não retroagirá nunca, uma vez que está vedada a cobrança de tributos em relação a fatos imponíveis ocorridos antes do início da vigência da lei que os houver instituído ou aumentado".

183 Ensina CÂNDIDO RANGEL DINAMARCO, A reforma do Código de Processo Civil, pp. 39-40, que: "Seja no trato da autêntica retroatividade, seja no exame da admissibilidade da aplicação imediata, existem limites a observar. A Lei de Introdução ao Código Civil, que contém normas de superdireito (normas sobre a aplicação do direito) mas não deixa de ser uma lei ordinária (do mesmo nível hierárquico das leis cuja aplicação ela regula), serve somente para traçar regras interpretativas quanto à retroação ou aplicação imediata de uma lei nova. Mas os preceitos que ela contém não prevaleceriam a ponto de impedir a eficácia de uma expressa determinação, eventualmente contida em outra lei do mesmo nível, no sentido de sua própria aplicação imediata ou mesmo de sua projeção a fatos pretéritos ou situações já consumadas (ingênua determinação, disse Vidigal). A firmeza de uma limitação temporal à eficácia da lei nova só pode vir de normas de nível mais elevado e a isso atende a Constituição Federal ao traçar limites representados pelo direito adquirido, pelo ato jurídico perfeito e pela coisa julgada (const., art. $5^{\circ}$, inc. XXXVI)."

${ }^{184}$ Devemos fazer uma ressalva de ordem terminológica. O princípio da irretroatividade da lei foi colocado no centro de muitas teorias com significados distintos já que o conceito de retroatividade foi alterado com a evolução da doutrina, o que impõe ao estudioso do tema uma análise do seu conteúdo para identificar como
} 
Dito isto, entendemos que em nosso ordenamento a lei ordinária poderá ser retroativa desde que (a) não fira direitos adquiridos, atos jurídicos perfeitos e a coisa julgada e (b) contenha regra expressa sobre a sua eficácia retroativa, porque essa não pode ser presumida ${ }^{185}$.

\subsection{Direito adquirido, ato jurídico perfeito e coisa julgada}

Nota-se do texto constitucional uma aparente peculiaridade de nosso sistema, qual seja a de imunizar não só os direitos adquiridos como também os atos jurídicos perfeitos e a coisa julgada quanto a alterações legislativas futuras ${ }^{186}$.

A menção expressa a esses três institutos tanto na Constituição como na Lei de Introdução ao Código Civil permite que se questione qual o verdadeiro alcance da proteção constitucional.

Alguns autores entendem que a explicitação desses três institutos foi meramente didática e a proteção poderia ser dirigida exclusivamente aos direitos adquiridos ${ }^{187}$. No ponto extremo, encontra-se o posicionamento da

se aplica o princípio. Exemplificativamente, GABBA afirmou a existência do princípio da não retroatividade da lei, fazendo a ressalva de que ela não deveria atingir direitos adquiridos. Isso significava que, nos casos em que não viesse a ferir direitos adquiridos, a lei deveria ser retroativa. Lembrando-se que ele pensava como retroativa a lei que atingisse facta pendentia. Os facta praeterita jamais poderiam ser atingidos pela lei e o princípio da não retroatividade não se referia a eles. Teoria della retroattvità..., vol I, passim. De nossa parte, aderimos ao conceito de retroatividade proposto por ROUBIER e quando afirmamos o princípio da irretroatividade das leis estamos nos referindo à impossibilidade dessa atingir facta praeterita ou, com relação aos facta pendentia, de atingir os efeitos anteriores ou os momentos de constituição e extinção da situação jurídica, sem que haja disposição expressa a esse respeito.

${ }^{185}$ Perfilamos as lições de LIMONGI FRANÇA que ao afirmar a existência do princípio da irretroatividade das leis esclareceu que: "Com as Constituiçôes de 1934, 1964 e 1988, embora diversa tenha sido a fórmula adotada no preceito sobre a matéria, sustentamos que o seu conteúdo continua o mesmo. Os dispositivos dessas Leis Magnas, em suma, vieram atender à regra implicitamente já contida nas de 1824 e 1891, qual seja a de que as leis não têm efeito retroativo em princípio, podendo entretanto tê-lo, por disposição expressa, se não ofenderem Direito Adquirido" (A irretroatividade das leis..., p. 192).

${ }^{186}$ HAROLDO VALLADÃO referiu-se à proteção aos direitos adquiridos, ao ato jurídico perfeito e à coisa julgada previstos no art. 141, § $3^{\circ}$, da Constituição de 1.946 afirmando que "esse preceito constitui a fórmula brasileira da não retroatividade" (Lei geral de aplicação... p.121).

${ }^{187}$ Comentando o art. $3^{\circ}$ da LICC em sua redação original assim se manifestou o ex-ministro do Supremo tribunal Federal JOÃO LUIZ ALVES: "Na noção de direito adquirido se compreende a irretroatividade da lei, em relação ao fato jurídico perfeito e à coisa julgada, pois aquêle e esta, têm por objeto direitos, cuja 
corrente que extrai dessa explicitação uma brecha para concluir que a proteção constitucional abarca tanto a teoria subjetivista como a objetivista de ROUBIER.

Esse último entendimento parte da observação primordial de que os atos jurídicos perfeitos, segundo a definição da LICC, são aqueles já consumados segundo a lei vigente ao tempo que se efetuaram. Daí afirma que a consumação a que se refere a lei não diz respeito à consumação do direito, mas à formação do ato. Assim, uma vez que a Constituição resguarda o ato jurídico perfeito, não pode a lei posterior desconsiderar a circunstância de sua própria existência ${ }^{188}$.

Em que pese o eruditismo com que essas lições foram colocadas, de nossa parte discordamos de seu acerto. Parece-nos, em verdade, que ao se referir aos atos jurídicos perfeitos e defini-los como os já consumados, a lei estava de fato referindo-se aos direitos já exauridos, aos negotia praeteria. ${ }^{189}$

Duas razões nos levam a essa conclusão. A primeira, de ordem histórica. Devemos recordar que a "fórmula brasileira" de direito intertemporal surgiu em uma época em que o texto constitucional dizia que a lei não poderia ser retroativa, mas a doutrina entendia essa limitação em consonância com o pensamento de GABBA ${ }^{190}$. Não podemos deixar de remarcar, por outro lado, que a doutrina do Professor pisanês sequer considerava a hipótese de a lei vir a ferir atos consumados ou a coisa julgada. Esses exemplos estavam acobertados pela figura da retroatividade impossível e o conceito de direito adquirido era desnecessário para protegê-los ${ }^{191}$.

aquisição se verifica pela perfeição do ato jurídico ou pelo julgamento definitivo do litígio" (Código civil da República dos Estados Unidos do Brasil, $1^{\circ}$ vol., p. 52).

${ }^{188}$ FÁBIO PESSOA, Elementos para uma teoria..., pp. 67-71, esp. p. 71.

${ }^{189}$ Esse é o entendimento de FELIPE ANTÔNIO MARCHI LEVADA, $O$ direito intertemporal $e$ os limites da proteção do direito adquirido, p. 82, que, fundamentado nas lições de CARVALHO SANTOS e JOSÉ AFONSO DA SILVA, assegura: "A proteção conferida ao ato jurídico perfeito tem não só a finalidade de proteger uma das causas geradoras do direito adquirido, mas também os atos completamente exauridos" e, mais adiante explica "Assim, um ato que já tenha produzido os seus efeitos não poderá ser atingido por lei posterior. Contudo, da mesma forma que se dá com os direitos adquiridos de maneira complexa, os atos jurídicos perfeitos são protegidos apenas quanto às partes já exauridas, sendo atingidos pela lei nova desde que não constituam direito adquirido - nas partes ainda não completadas”.

${ }^{190}$ De fato, a primeira vez em que essa fórmula surgiu em um texto legislativo foi no Projeto de COELHO RODRIGUES datado de 1.897, época em que vigia a Constituição de 1.891.

${ }^{191}$ Teoria della retroattività..., vol. I, pp. 34-38. 
Feitas essas considerações fica fácil perceber que a "fórmula brasileira" do direito intertemporal surgiu para abraçar de maneira bastante completa a teoria de GABBA.

Por outro lado, não parece haver motivo para alterar esse entendimento. Em que pese nosso ordenamento ter sido influenciado grandemente pela doutrina de ROUBIER durante o período de vigência do Decreto-Lei 4.657/42 até a Constituição de 1.946 e, ainda, de ser plenamente possível encontrar traços desse sistema na LICC, não se afigura razoável interpretar que a proteção constitucional contra a retroatividade tenha por objetivo imunizar a constituição de atos jurídicos que não gerem direitos adquiridos.

O sistema de proteção constitucional dos direitos adquiridos, do ato jurídico perfeito (entendido como ato cujos efeitos já se exauriram) e da coisa julgada, combinado com a proteção legal contra a retroatividade da lei, já é por si só suficiente para garantir o postulado de segurança jurídica. Por isso, não existe razão para impossibilitar o legislador de editar normas retroativas, desde que elas não venham a ferir as garantias previstas na Constituição ${ }^{192}$.

Frise-se, ademais, que a amplitude do conceito de direito adquirido contida na LICC é entendida em extensão bem maior do que a da teoria de GABBA, o que é mais um motivo para não se conferir uma interpretação tão abrangente ao conceito de ato jurídico perfeito constante dessa lei.

Merecem destaque também as observações de FÁBIO TABOSA PESSOA sobre o conteúdo da garantia constitucional da coisa julgada, em termos de direito intertemporal.

Em sua concepção, não se pode associar a coisa julgada à proteção de direitos adquiridos ${ }^{193}$, conforme pretendeu CLÓVIS BEVILÁQUA ao

\footnotetext{
${ }^{192}$ Veja-se que nem mesmo ROUBIER era favorável a que o princípio da irretroatividade da lei fosse tratado em nível constitucional (Le droit transitoire, pp. 224-225).

193 Elementos para uma teoria..., pp. 72 e ss.
} 
redigir a Lei de Introdução ao Código Civil $^{194}$. Também não se deve fazer qualquer associação entre a coisa julgada e o ato jurídico perfeito ${ }^{195}$.

Começaremos pela segunda explicação, com a qual concordamos integralmente. Para afastar a idéia de que haja uma redundância na proteção dos atos jurídicos perfeitos e da coisa julgada demonstra o autor, basicamente, que não se deve confundir a coisa julgada com a sentença. Essa corresponde a um ato jurídico (judicial), aquela é qualidade desse ato quando não mais sujeito a recursos. A distinção parece tão clara, que mais não é preciso acrescentar para afastar de vez qualquer possibilidade de se entender que a proteção da coisa julgada está contida na de ato jurídico perfeito.

Já no que diz respeito à impossibilidade de associação das idéias de coisa julgada e direito adquirido, entendemos ser necessário fazer algumas ressalvas ao pensamento do autor.

Parte ele da afirmação de que o espectro alcançado pela coisa julgada é mais amplo do que o dos direitos adquiridos. Isso porque, pode ela se manifestar também no tocante a decisões outras, de cunho positivo, que não envolvam a formação ou o reconhecimento de determinados direitos (ou pelo menos não se limitem a isso), como no caso de constituição ou desconstituição de relações jurídicas diversas ${ }^{196}$. Além disso, nos casos em que a sentença julga improcedente a demanda ou julga procedente uma ação declaratória negativa, não estaria protegendo nenhum direito adquirido.

\footnotetext{
${ }^{194}$ Assim se posicionou CLÓVIS BEVILÁQUA sobre a tríplice proteção contida na LICC: “O direito quer que o acto jurídico perfeito seja respeitado pelo legislador e pelo interprete na applicação da lei, precisamente porque o acto juridico é gerador, modificador ou extinctivo de direitos. Se a lei pudesse dar como inexistente ou inadequado o acto jurídico, já consumado segundo a lei vigente ao tempo em que se effectuou, o direito adquirido delle oriundo desappareceria por falta de titulo ou fundamento. Assim a segurança do acto jurídico perfeito é um modo de garantir o direito adquirido, pela proteç̧ão concedida ao seu elemento gerador. Também o é a cousa julgada, que o Codigo define - a decisão judicial de que já não cabe recurso" (Codigo Civil dos Estados Unidos do Brazil comentado, vol. I, p. 95).

${ }^{195}$ Essa associação foi feita por LIMONGI FRANÇA, A irretroatividade das leis..., p. 222: "De nossa parte, assinalamos uma dupla redundância do Legislador. Não só a coisa julgada seria uma das causas geradoras do Direito Adquirido, mas ainda uma variedade do ato jurídico perfeito, de natureza constitucional”.

196 Elementos para uma teoria..., p. 73.
} 
Feitas essas observações o processualista paulista passa a demonstrar que a proteção da coisa julgada contida no texto constitucional também não é redundante a partir da noção de irretroatividade da lei.

De início, assume que pela coisa julgada é possível reconhecer a formação de situações jurídicas novas, que decorrem do conteúdo da decisão transitada em julgado. Logo em seguida afirma que não há redundância na proteção constitucional, por três motivos fundamentais.

O primeiro diz respeito ao modo como a doutrina se posiciona a respeito da existência ou não de um princípio da irretroatividade da lei insculpido nos moldes da teoria objetivista. Observa que não é pacífica a aceitação de aproximação do nosso sistema com a teoria objetivista e, ademais, ao tempo em que a garantia foi prevista pela primeira vez na Lei de Introdução ao Código Civil nossa doutrina acolhia pacificamente a doutrina subjetivista ${ }^{197}$.

O segundo fundamento é o de que determinadas situações jurídicas criadas a partir do trânsito em julgado da sentença são especiais, por não corresponderem a qualquer situação jurídica de direito material, em concreto, como ocorre no caso das decisões de improcedência ou de procedência de ações declaratórias negativas, afirmando a inexistência de relação jurídica substancial.

Por fim, entende que as situações jurídicas criadas pelas decisões de cunho afirmativo são situações diferenciadas, em função da eliminação de toda e qualquer liberdade interpretativa acerca da matéria, e pela limitação dos contornos e efeitos correspondentes nos termos da decisão judicial ${ }^{198}$.

\footnotetext{
${ }^{197}$ Elementos para uma teoria..., p. 74. Após fazer essa observação, o autor pontifica "e é na origem que se deve buscar a compreensão do instituto, sendo certo que, ali, não se podia falar nas situações jurídicas como elemento genérico a inspirar de forma direta o sistema". Essa afirmação parece paradoxal com o restante de sua linha de pensamento, não só porque, ao configurar o ato jurídico perfeito seu raciocínio distanciou-se por completo da doutrina que reinava na origem dessa proteção, como pelo fato dessa mesma idéia ter permeado a dissociação da proteção da coisa julgada com a dos direitos adquiridos.

198 Elementos para uma teoria..., p. 75.
} 
Por todos esses motivos a conclusão a que chega é a de que tanto o ato jurídico perfeito como a coisa julgada podem ser fontes de direitos adquiridos, mas sua utilidade consiste justamente nos casos em que extrapolam essa possibilidade, o que, ironicamente, conduz a uma aproximação do nosso sistema da teoria objetivista ${ }^{199}$.

Embora os termos do problema tenham sido colocados com bastante clareza e analisados em profundidade, entendemos que seu maior acerto está em dar um enfoque processualístico para um fenômeno que é comumente tratado de maneira alheia aos conceitos e princípios do direito processual. De resto, acreditamos que muitas das conclusões alcançadas nessas lições são equivocadas em função da adoção de premissas com as quais não concordamos.

Para explicar nosso posicionamento iniciaremos por questionar: em que consiste a proteção da coisa julgada para o direito intertemporal?

Admitindo-se o posicionamento de LIEBMAN, bastante difundido entre nós - e seguido até mesmo pelo redator do Código de Processo Civil ALFREDO BUZAID ${ }^{200}$-, segundo o qual devemos distinguir a autoridade da coisa julgada dos efeitos da sentença, podemos perceber que 0 traço fundamental do instituto da coisa julgada é a sua possibilidade de eliminar a crise de direito material mediante a afirmação definitiva da existência ou inexistência de um direito subjetivo que foi objeto do litígio ${ }^{201}$.

De fato a coisa julgada criará uma situação jurídica nova com relação à situação (relação) estabelecida entre os litigantes, mas essa

\footnotetext{
${ }^{199}$ Elementos para uma teoria..., p. 75, esp. nota 209.

${ }^{200}$ ALFREDO BUZAID, Exposição de motivos do projeto de lei de código de processo civil, item 10.

${ }^{201}$ Esse traço também pode ser encontrado na doutrina de BARBOSA MOREIRA, que associa a coisa julgada somente com a imutabilidade do comando da sentença (e não de seus efeitos). No entendimento do professor carioca "a coisa julgada - nunca será demais repeti-lo - é instituto de finalidade essencialmente prática: destina-se a conferir estabilidade à tutela jurisdicional dispensada. Para exercer de modo eficaz tal função, ela deve fazer imune a futuras contestações o resultado final do processo" ("Coisa julgada e declaração”, p. 83).
} 
situação tem íntima relação com o direito discutido na demanda ${ }^{202}$. O que haverá de novo na relação entre os demandantes é que a disputa pelo bem da vida que compunha o litígio será definitivamente eliminada mediante a afirmação de que uma das partes é a titular do bem disputado. Nada há de diferente quanto a isso nas demandas julgadas improcedentes ou mesmo nas declaratórias negativas.

Nas primeiras o direito do réu de não ter sua esfera jurídica invadida será reconhecido e é esse direito que será protegido ${ }^{203}$. Nas outras, igualmente existe uma proteção subjetiva de ver reconhecida como inexistente uma situação jurídica que está sendo colocada em dúvida por alguém e que pode acarretar consequências na esfera jurídica daquele que se julga titular do direito de eliminar a crise de certeza ${ }^{204}$.

Visto ainda de outra maneira, a partir do trânsito em julgado da demanda nasce para o vencedor um direito subjetivo de não ter que se sujeitar a uma nova lide envolvendo as mesmas partes, a mesma causa de pedir e o mesmo pedido.

\footnotetext{
${ }^{202}$ Isso porque quando "se passa das especulações abstratas para a observação das concretas situações de conflitos entre indivíduos ou grupos (crises jurídicas), percebe-se uma proximidade muito significativa entre certos institutos francamente processuais e a situação de direito substancial em relação à qual o processo atuou ou deve atuar" (DINAMARCO, Instituições, vol. I, p. 44).

${ }^{203} \mathrm{O}$ direito subjetivo do demandante ou do demandado não pode ser analisado estritamente do ponto afirmativo, ou seja, somente a partir do reconhecimento de um direito pela sentença. Qualquer situação de vantagem ou desvantagem com relação a um determinado interesse pode ser entendido como direito subjetivo (v. BEDAQUE, Direito e processo, p. 9) e, nesse sentido, a eliminação de uma crise de certeza quer pelo julgamento de improcedência da demanda ou pela procedência de uma ação declaratória negativa afirma direitos subjetivos. FLÁVIO LUIZ YARSHELL, Tutela jurisdicional, pp. 28 e ss., demonstra que a expressão tutela jurisdicional pode ser entendida tanto em função dos meios como do resultado do processo. Por esse último enfoque é possível afirmar que será concedida àquele que se sagrar vencedor do processo, que, no processo de conhecimento tanto pode ser o autor como o réu. Feitas essas considerações observa que "com efeito, se a tutela jurisdicional é aquela prestada em prol do vencedor, ela somente se estabelece em favor de quem ostenta um direito, considerado o plano substancial do ordenamento". Para FAZZALARI, Note in tema di diritto e processo, p. 103, o direito à integridade da própria esfera jurídica deve ser reconhecido como um direito inativo absoluto.

${ }^{204}$ De fato nosso sistema não autoriza a propositura de demandas declaratórias que não tenham por fim a eliminação de uma crise de certeza que não acarrete quaisquer conseqüências para as partes. Com o perdão do exemplo "de escola", se dois amigos começam uma discussão para ver quem é torcedor mais fiel de um time de futebol e um deles chega a afirmar que o outro nem sequer pode ser considerado torcedor daquele time, a dúvida criada sobre o entendimento que um deles faz sobre a qualidade de torcedor do outro não poderá ser levada ao Poder Judiciário para que seja solucionada. Faltará interesse ao demandante se ele pedir a um juiz que declare que ele é torcedor do seu time de coração, porque dessa declaração não poderá advir qualquer alteração na sua esfera de direitos. Conforme os ensinamentos de ALFREDO BUZAID, $A$ ação declaratória no direito brasileiro, p. 157, "O interesse de agir (na ação declaratória), portanto, pressupõe os seguintes requisitos: a incerteza jurídica, um dano originado, para o autor, de tal incerteza e a idoneidade da sentença para eliminar tal dano".
} 
Quer se associe esse direito ao próprio direito material em disputa, ou se confira tratamento autônomo a ele, não se pode deixar de notar que a proteção constitucional é subjetiva e dirige-se aos direitos afirmados na sentença e tornados imunes a partir do trânsito em julgado.

Conclui-se, destarte, que os atos jurídicos perfeitos a que a Constituição alude são os negotia praeterita e a proteção dirigida à coisa julgada tem íntima relação com os direitos dos litigantes, não devendo ser compreendida de maneira dissociada da corrente subjetivista.

\subsection{Limite de atuação do constituinte derivado}

Questão que abre campo para discussões infindáveis diz respeito à possibilidade de uma Emenda à Constituição vir a ferir direitos adquiridos.

Poder-se-ia supor que tratando-se de normas com a mesma hierarquia - já que tanto uma como outra são normas constitucionais - a norma contida na Emenda Constitucional, por ser posterior, deveria prevalecer com relação à primeira. Outro argumento favorável a essa tese é o de que o dispositivo contido no inc. XXXVI da Constituição Federal afirma que a lei não ferirá direitos adquiridos, o que dá a entender que uma Emenda Constitucional poderia fazê-lo.

Ocorre que os direitos adquiridos estão contidos no art. $5^{\circ} \mathrm{da}$ Constituição Federal e correspondem a uma garantia individual contra quaisquer espécies de normas tendentes a atingi-los. Some-se a esse fato que, vacinado contra os riscos que a concessão de poderes irrestritos aos constituintes derivados poderia representar, o constituinte originário de 1.988 houve por bem limitar o poder de reforma da Constituição Federal, instituindo cláusulas pétreas 
no seu art. $60, \S 4^{\circ}$, dentre as quais destaca-se a impossibilidade de supressão de direitos e garantias individuais (inc. IV) ${ }^{205}$.

Revela-se, assim, que nem mesmo uma Emenda à Constituição pode instituir normas que venham a ferir essas garantias individuais, sendo inconstitucionais as disposições de Emendas Constitucionais que afetem direitos adquiridos ${ }^{206}$.

Os defensores da corrente que afirma a possibilidade das Emendas Constitucionais virem a ferir as garantias previstas no inc. XXXVI, do art. $5^{\circ}$, da Constituição Federal, argumentam que a vedação contida no art. $60, \S$ $4^{\circ}$, inc. IV, da Carta Magna diz respeito tão somente à impossibilidade de supressão da garantia em abstrato prevista no inc. XXXVI, e não aos direitos individuais em concreto $^{207}$. Ou seja, o constituinte derivado estaria impossibilitado de criar uma Emenda Constitucional que permitisse que a lei ferisse direitos adquiridos, mas nada poderia impedi-lo de, por meio de norma constitucional, ferir uma dessas garantias em concreto.

Todavia, com todo o respeito aos partidários desse entendimento, cremos que ele não se sustenta.

Primeiramente, porque do ponto de vista histórico o argumento é bastante frágil. Consoante vimos nos tópicos precedentes, a proteção constitucional do direito adquirido no Brasil remonta aos primórdios de

\footnotetext{
${ }^{205}$ Dispõe o art. 60 , $\S 4^{\circ}$, inc. IV, da CF que: "§ $4^{\circ}$. Não será objeto de deliberação a proposta de emenda tendente a abolir: (...) IV - os direitos e garantias individuais".

${ }^{206}$ JOSÉ AFONSO DA SILVA, após lecionar que o poder de reforma constitucional "por ser uma forma de poder constituído ou instituído, é poder regrado, condicionado e limitado", observou com relação à limitação constante do dispositivo constitucional acima mencionado que "ninguém duvida de que se configura como uma típica garantia individual a regra constante do inc. XXXVI do art. $5^{\circ}$ da Constituição de 1988, segundo a qual a lei não pode prejudicar o direito adquirido. O argumento é irretorquível, como um entinema: a reforma constitucional não pode abolir direito adquirido porque se trata de uma garantia individual. Ou se quiser em forma de um silogismo: a reforma constitucional não pode abolir direitos $e$ garantias individuais; o direito adquirido é uma garantia individual expressa no art. $5^{\circ}$, XXXVI; logo, a reforma constitucional não pode abolir direito adquirido. Ou ainda, por outra forma: os direitos e garantias individuais são imodificáveis por emenda constitucional; o direito adquirido é uma garantia constitucional; logo, o direito adquirido é imodificável por emenda constitucional" ("Reforma Constitucional e direito adquirido", pp. 129-130).

${ }^{207}$ Assim, por exemplo, FABIO PESSOA, Elementos para uma teoria geral..., pp. 84-85 e JOSÉ EDUARDO MARTINS CARDOZO, Da retroatividade da lei, pp. 313-314.
} 
nossa independência e esteve presente em quase todos os textos constitucionais. Não é razoável supor que haja qualquer risco de o constituinte derivado pretender suprimir o art. $5^{\circ}$, inc. XXXVI, do texto constitucional. Por outro lado, se voltarmos os olhos ao momento histórico da promulgação da Constituição de 1.988 momento de regresso a um regime democrático de direito -, veremos que a chamada Constituição Cidadã buscou garantir os indivíduos contra abusos praticados pelo Estado. Não é de se supor, portanto, que ao instituir cláusulas pétreas na Constituição Federal, o constituinte originário pretendesse apenas e tão somente proteger os cidadãos contra a possibilidade de que uma Emenda à Constituição viesse a suprimir em abstrato a garantia constante do art. $5^{\circ}$, inc. XXXVI, da Carta Magna.

Analisando a questão por outro ângulo, de nada adiantaria a existência da garantia em abstrato se ela não fosse de fato uma garantia. Vale dizer, a norma contida no art. 60, $\S 4^{\circ}$, inc. IV, da Constituição Federal seria inócua se ela não se dirigisse aos direitos e garantias individuais em concreto dos indivíduos, porque é totalmente ilógico impedir que o constituinte derivado crie normas ofensivas aos direitos e garantias individuais se essa vedação não servir para impedir que direitos e garantias pertencentes aos indivíduos (ou seja em concreto) sejam efetivamente protegidos ${ }^{208}$.

Resta claro, portanto, que nem mesmo o constituinte derivado poderá editar normas constitucionais que venham a ferir direitos adquiridos, atos jurídicos perfeitos ou a coisa julgada, sendo raras as hipóteses em que essas garantias individuais poderão ser ofendidas por Emenda à Constituição. Essa possibilidade refere-se a casos excepcionalíssimos em que a

\footnotetext{
208 Ao enfrentar o argumento dos que defendem que a garantia constitucional dirige-se apenas à impossibilidade de supressão do art. 5 inc. XXXVI do corpo da Constituição, JOSÉ AFONSO DA SILVA, "Reforma constitucional...", p. 131, taxativamente asseverou que: "Um tal argumento e uma tal doutrina vale como uma fraude à Constituição, porque eliminaria a garantia do direito mediante a supressão do direito adquirido. Se isso fosse possível, de nada adiantaria a proteção normativa de um direito, pois, precisamente quando esse direito se efetiva e se concretiza num titular, pode ser eliminado. É o mesmo que suprimir, a cada passo, a norma de garantia, por esvaziá-la de seu conteúdo jurídico: seu efeito prático. Demais, quando a cláusula dita pétrea diz que é vedada proposta tendente a abolir..., isso significa que a vedação atinge a pretensão de modificar qualquer dos elementos conceituais da situação objetiva ou subjetiva protegida, isto é, que se encaminhe, 'tenda' ( emenda 'tendente', diz o texto) para a sua abolição, ou emenda que 'tenda' a enfraquecer qualquer dos direitos e garantias individuais constantes do ser. $5^{\circ}$, como ocorreria se se admitisse a abolição dos efeitos concretos em favor de alguém desses direitos $e$ garantias".
} 
supressão do direito adquirido, do ato jurídico perfeito ou da coisa julgada decorre da necessidade de proteção a um valor também protegido na Constituição Federal, que seja tão ou mais importante do que aqueles.

\section{Capítulo V - Autonomia do direito processual civil intertemporal}

\subsection{Direito processual intertemporal}

Existe um direito processual intertemporal?

Essa indagação não se refere à divisão da ciência jurídica em ramos estanques que não se comuniquem, nem à possibilidade de existirem conflitos de leis processuais no tempo. O que se pretende com ela é tão somente saber se as particularidades do direito processual justificam um estudo autônomo da matéria, com a fixação de premissas e a utilização de conceitos próprios.

As respostas para tal pergunta são bastante variadas. Parte da doutrina nada fala sobre o direito processual intertemporal, ou afirma simplesmente que o processo civil intertemporal é inteiramente regido pelo princípio tempus regit actum, impondo-se, destarte, a aplicação imediata da lei processual aos processos pendentes, respeitando-se os atos anteriormente praticados $^{209}$. Nessas lições normalmente não se faz uma ressalva sobre a necessidade de estudo separado da disciplina, aplicando-se em regra os mesmos conceitos da teoria geral do direito ao direito processual intertemporal.

\footnotetext{
${ }^{209}$ NELTON DOS SANTOS, Código de Processo Civil Interpretado, p. 2.702, explica o fundamento do direito processual intertemporal a partir do disposto no art. $5^{\circ}$, inc. XXXVI, da Constituição Federal e perfilase à corrente que não confere tratamento diferenciado à disciplina ao entendimento de que "desse dispositivo constitucional deriva o princípio da irretroatividade das leis, perfeitamente aplicável ao direito processual”. Em sentido análogo WELLINGTON MOREIRA PIMENTEL asseverou: "Do que foi dito em rápidas $e$ largas pinceladas, percebe-se sem esforço maior que a lei processual não destoa das demais quanto a sua eficácia no tempo. Afina, isto sim, no mesmo diapasão: dispõe para o futuro. O que difere é a relação jurídica que disciplina.” (“Questões de direito intertemporal diante do Código de Processo Civil”, p. 128).
} 
Há também defensores da corrente de que as leis processuais têm aplicação diferenciada no tempo em virtude do seu caráter público, o que impõe a sua aplicação imediata.

Alguns doutrinadores vislumbram a diferenciação da eficácia da lei processual no tempo em função de particularidades da relação jurídica processual, especialmente seu caráter extremamente complexo e a existência de um elo entre todos os atos processuais que convergem para um único fim, a sentença. Existem, ainda, defensores de que a autonomia da relação jurídica processual é o fator determinante para diferenciar a norma processual das demais, com relação a sua eficácia temporal.

Entendemos que o acerto está com a corrente que defende a especificidade do direito processual civil intertemporal, contudo por razões distintas das que são normalmente apresentadas pela doutrina. Antes de expô-las analisaremos mais detalhadamente os posicionamentos apresentados até aqui pela doutrina para justificar o estudo do direito processual intertemporal.

\subsection{Análise das justificativas conferidas pela doutrina para o estudo autônomo do direito processual civil intertemporal}

\subsubsection{Direito processual e ordem pública}

Não é incomum encontrar em doutrina e jurisprudência afirmações de que as normas processuais aplicam-se imediatamente por serem 


\title{
de ordem pública ${ }^{210}$. Partidários dessa corrente chegam a afirmar que a lei processual é retroativa ${ }^{211}$ em virtude desse caráter público.
}

\author{
A primeira afirmativa decorre do vício de se justificar \\ qualquer diferença da norma processual em função da ordem pública ${ }^{212}$ a \\ segunda, além desse vício, provém da utilização imprecisa do termo \\ retroatividade, confundindo-o com o conceito de eficácia imediata da le ${ }^{213}$. De \\ fato, quando encontramos afirmativas no sentido de ser a norma processual \\ retroativa por ser de ordem pública, normalmente elas são feitas para dizer que a
} lei processual deve ser aplicada imediatamente aos processos pendentes ${ }^{214}$, o

${ }^{210}$ ROBERTO ROSAS, mesmo tendo observado expressamente que "quando a Lei de Introdução estipulou que a lei terá efeito imediato e geral (art. $6^{\circ}$ ), não distinguiu a lei de ordem pública ou não, mas ressalvou o ato jurídico perfeito, o direito adquirido e a coisa julgada" afirma logo na seqüência que "A lei processual é de ordem pública, portanto de aplicação imediata, desde que não atinja essas situações" ("Direito intertemporal processual”, p. 10). No mesmo caminho afirma MIRNA CIANCI, "Direito intertemporal e a Lei 11.232", p. 1, que "tratando-se de matéria processual, com caráter de ordem pública, em regra tem imediata aplicabilidade, ressalvadas as situações consolidadas”.

${ }^{211} \mathrm{O}$ equívoco apontado pode ser notado na seguinte passagem de JORGE AMERICANO, ao comentar o art. 1.047 do Código de Processo Civil de 1.939, que afirmava a aplicabilidade imediata da lei processual aos processos pendentes: “Aplica-se, neste artigo, a regra da retroatividade das leis do processo, às causas pendentes, com ressalva dos atos continuados indivisiveis, como seja a instrução da causa ( $\$ 1^{\circ}$ ), que deve terminar segundo o sistema pelo qual houver sido iniciada" (Comentários ao Código de Processo Civil do Brasil, vol. 4, p. 453). Para CARLOS MAXIMILIANO: “As leis de processo retroagem, na aparência, isto é, aplicam-se imediatamente, até mesmo aos direitos adquiridos antes de sua emanação e tanto aos feitos já começados quando advieram as novas regras formais, como as (sic) posteriores" (Direito intertemporal ou teoria da retroativadade das leis, p. 264). Na doutrina estrangeira JOSSERAND admite que as leis de ordem pública podem ferir direitos adquiridos, embora afirme que nesses casos tratar-se-á de eficácia imediata da lei (Cours de droit civil positif français, vol. I, pp. 62-63). Todavia, ao admitir que o aumento de idade para maioridade de 21 para 25 anos atinja a capacidade daqueles que se encontram com idade entre 21 e 25 anos (pp. 60-61), o autor se distancia do conceito de retroatividade de ROUBIER e acaba por conferir eficácia retroativa às leis de ordem pública.

${ }^{212}$ Com relação a esse vício, destacamos os ensinamentos de RICARDO DE CARVALHO APRIGLIANO, que em recente tese de doutorado concluiu que a aplicação da ordem pública de direito processual "está diretamente relacionada ao propósito de salvar processos e permitir que sejam julgados quanto ao mérito,e não o de gerar a extinção sem tal exame, diante da suposta necessidade de tutelar categorias processuais que, de um modo geral vêm sendo mal interpretadas e aplicadas. A pretexto de realizar tal controle, os operadores do direito se esquecem dos objetivos deste mesmo controle e acabam sustentando posições que se valem do remédio para causar a doença, e não para evitá-la” (A ordem pública no direito processual civil, p. 290).

${ }^{213}$ Analisando esse mesmo problema CHIOVENDA foi incisivo ao afirmar que tratar a lei processual como retroativa é um erro, e diferenciá-la por seu caráter público é equívoco (Instituições de direito processual civil, $1^{\circ}$ vol., p. 86).

${ }^{214}$ Nesse sentido, após observarem que "o princípio fundamental, admitido pela universalidade dos autores e pela jurisprudência antiga e moderna, é que a lei processual é, em regra, retroativa, aplicando-se imediatamente a todas as controvérsias submetidas aos juízes e tribunais, desde que não tenha sido proferida sentença irrecorrível”, esclarecem EDUARDO ESPÍNOLA e EDUARDO ESPÍNOLA FILHO que tanto os partidários da doutrina subjetivista como da objetivista estão de acordo nesse ponto, sendo certo que os objetivistas "não admitem que se digam retroativas as leis processuais; mas isso porque, no caso, não vêem qualquer retroatividade, e sim a aplicação imediata da nova lei, por sua natureza e alcance social: a sua aplicação não se refere a um fato passado, mas a um fato atualmente existente, isto é: a lide, que 
que, como visto nos tópicos 3.8 e 3.9, não é fenômeno ligado à retroatividade da lei, mas a sua eficácia imediata.

Utilizando significados distintos para o mesmo conceito, tais doutrinadores partem da premissa de que o caráter público da norma processual é fator que a diferencia das demais na teoria geral do direito intertemporal. 0 equívoco dessa premissa vem sendo apontado há bastante tempo, mas ainda hoje a doutrina da ordem pública ecoa, especialmente na jurisprudência que trata do direito processual intertemporal ${ }^{215}$.

Existem três razões fundamentais para demonstrar que esse entendimento não é adequado. A primeira é a inexistência de norma que confira tratamento diferenciado às leis de ordem pública no que se refere a sua eficácia temporal. De fato, o art. 50, inc. XXXVI, da Constituição Federal trata da lei em sentido geral quando confere proteção aos direitos adquiridos, ao ato jurídico perfeito e à coisa julgada e 0 art. $6^{\circ}$ da Lei de Introdução ao Código Civil também não faz qualquer distinção quando afirma a eficácia imediata da lei.

cumpre manter distinta do negócio jurídico, que forma o seu objeto e lhe dá origem." (Da lei, da sua obrigatoriedade, do direito intertemporal, pp. 244-245).

${ }^{215}$ A propósito a posição de MIRNA CIANCI acima citada apóia-se no seguinte julgado por ela colacionado: SERVIDOR. URP. 26, 05\%. INCORPORAÇÃO. PROCESSO CIVIL. EMBARGOS À EXECUÇÃO. ALTERAÇÃO DA DECISÃO EXEQÜENDA. IMPOSSIBILIDADE. ART. 741, PARÁRAFO ÚNICO, CPC. ALTERAÇÃO POR MEDIDA PROVISÓRIA. NORMA PROCESSUAL. ABRANGÊNCIA DOS PROCESSOS EM CURSO. TÍTULO JUDICIAL TRANSITADO EM JULGADO ANTES DA EDIÇÃO DA MEIDA PROVISÓRIA. As normas de direito processual, dada sua natureza de ordem pública, têm aplicação imediata, atingindo, inclusive, os processos pendentes de julgamento, impondo-se, no entanto, respeitar as situações jurídicas já consolidadas sob a vigência da lei anterior. O parágrafo único do art. 741 do Código de Processo Civil não deve incidir nos processos cuja sentença exeqüenda passou em julgado antes de sua entrada em vigor, sob pena de violação à coisa julgada. Agravo regimental a que se nega provimento. (STJ; Sexta Turma; rel. Min. PAULO MEDINA; AgRG no REsp 626.801/RN; j. 28.03.06; DJ 08.05.06, p. 304). À época em que julgou a questão da aplicabilidade da Lei 8.009/90 para desconstituir penhoras realizadas antes da vigência dessa lei o Superior Tribunal de Justiça também se manifestou no sentido de aplicabilidade imediata da lei por ser ela lei de ordem pública, como, exemplificativamente se verifica do AgRg no REsp 287.157/GO, de relatoria da Ministra NANCY ANDRIGHI (Terceira Turma;j. 27.06.02; DJ 09.09.02, p. 223 - fonte www.stj.jus.br, acessado em 17.11.09 às 20:01h), em cuja ementa se lê "a lei 8.009/90, por ser de ordem pública, tendente à proteção da moradia familiar tem aplicação imediata, incidindo no curso da execução, mesmo que já haja penhora realizada, mas alienação ainda não efetuada, $o$ que permite o levantamento da constrição dos bens afetados pela impenhorabilidade". Esse último entendimento do Superior Tribunal de Justiça além de apoiar-se na falsa premissa de que as leis de ordem pública detêm algum tratamento diferenciado em termos de direito intertemporal, acabou por incidir em duplo erro ao conferir eficácia retroativa para a Lei 8.009/90, desconstituindo penhoras licitamente realizadas sob o império da lei anterior e ferindo direitos adquiridos dos credores. Em sentido análogo, v. DINAMARCO, Instituições de direito processual civil, vol. I, p. 103. 
Dessa ausência de diferenciação constante da Lei de Introdução ao Código Civil surge o segundo fundamento para configurar o equívoco apontado. É que não só a lei de ordem pública tem eficácia imediata em nosso sistema de direito intertemporal como toda e qualquer lei também a tem. Assim, a eficácia imediata não pode ser eleita como um fator de distinção entre a lei de ordem pública das demais leis, porque essa é uma regra geral do sistema $^{216}$. A aplicação imediata da lei processual, portanto, não decorre de sua natureza pública. Ela se impõe, como de resto acontece com todas as demais leis, por ser entendida como um avanço legislativo que confere maior eficiência ao processo.

Por fim, a ordem pública em si não pode ser utilizada para justificar um tratamento diferenciado da eficácia normativa, especialmente quando se pensa em eficácia retroativa da lei, porque "em uma ordem jurídica fundada sobre a lei, a não-retroatividade das leis é ela mesma uma das colunas da ordem pública"217.

Ponto de vista peculiar sobre o tema é adotado por FÁBIO PESSOA ${ }^{218}$. Entende o autor que o interesse público subjacente tanto às normas de ordem pública (que em sua concepção são normas de direito privado que traduzem especial preocupação estatal) como às normas de direito público acarreta uma maior imperatividade de tais normas. Não para dar-Ihes eficácia imediata - porque isso seria próprio de todas as leis - mas para possibilitar que incidam retroativamente por vontade do legislador ${ }^{219}$, ou, ainda, para permitir que incidam sobre determinadas situações jurídicas não dotadas de caráter perpétuo, permitindo que a lei nova atinja tais situações mesmo que elas tenham dado

\footnotetext{
${ }^{216}$ Justamente por isso CHIOVENDA já havia alertado no início do século passado que "é equívoco asseverar que a lei processual é de imediata aplicação, porque isso é próprio de tôdas as leis, as quais, justamente por proverem para o futuro, se aplicarão imediatamente aos atos e fatos que se verificarem depois de posta em vigor a lei nova, exceto se, como dissemos, aquêles constituírem efeitos novos de fatos já anteriormente consumados" (Instituições de direito processual civil, $1^{\circ}$ vol, p. 87).

${ }^{217}$ ROUBIER, Le droit transitoire, p. 417. Após fazer essa afirmação o Professor francês arremata com a seguinte observação: "É absolutamente impossível conceber os fundamentos de uma ordem legislativa, se nós não introduzirmos a noção de não-retroatividade; pois se as leis devem ser retroativas, nós não mais chamaremos isso de ordem, mas de desordem pública".

${ }^{218}$ Elementos para uma teoria..., pp. 79-85.

${ }^{219}$ Para o autor essa possibilidade não existe no nosso ordenamento, já que ele entende que o princípio da irretroatividade das leis detém previsão constitucional no ordenamento jurídico brasileiro (Elementos para uma teoria..., p. 81.
} 
causa ao surgimento de direitos adquiridos ou a atos jurídicos perfeitos. Para explicar essa afirmação o autor parte da distinção feita por CARLOS MAXIMILIANO entre a aquisição e a existência do direito, e afirma que a lei nova pode afetar a existência de um direito, regulamentando o seu modo de existir ${ }^{220}$, mas não pode apagar o fato em si de sua constituição. Exemplificando o problema, o autor traz a questão da regulamentação do direito de vizinhança e o da abolição da escravatura.

A solução apontada não nos parece correta. Essa maior imperatividade das leis de ordem pública ou de direito público, como observado acima, não está prevista em texto normativo algum. Assim, falta fundamento legal para a afirmativa e, do ponto de vista hermenêutico, ela também não se justifica. Diferentemente do sustentado pelo autor, entendemos que o legislador pode criar normas retroativas e não vemos motivo para impossibilitar que essa retroação seja criada em normas privadas. O limite para essa atividade criativa está expresso no art. $5^{\circ}$, inc. XXXVI, da Constituição Federal, e consiste no respeito ao direito adquirido ao ato jurídico perfeito e à coisa julgada. Ademais, nos exemplos citados para justificar essa teoria o que se verifica é que ou não se tratavam de direitos passíveis de aquisição, ou de casos extremos em que a própria garantia constitucional do direito adquirido sucumbe diante de uma regra que suprime a possibilidade daquela modalidade de direito continuar a existir no ordenamento jurídico brasileiro. A solução nesse caso se dá pela aplicação do princípio da proporcionalidade $^{221}$ e não é extensível a toda e qualquer norma de ordem pública.

\footnotetext{
${ }^{220}$ Elementos para uma teoria..., p. 81, esp. nota 227. Em seguida (p. 82) conclui o processualista paulista que "a base do confronto entre a lei de ordem pública e instituições como o direito adquirido ou o ato jurídico perfeito, assim, está além do mero reconhecimento da formação em um dado momento histórico, mas na verificação dos limites possíveis de sobrevivência em face de alterações do ordenamento, à luz de fatores diversos ligados às próprias situações da vida consideradas e à natureza das regras inovadoras".

${ }^{221}$ Tomando por base os ensinamentos de ALEXY (Derecho y razón práctica, p. 12) para quem "as regras jurídicas são normas que exigem o cumprimento pleno e, nessa medida, podem sempre somente serem cumpridas ou descumpridas” parece-nos que tanto a determinação de que a lei não prejudicará o direito adquirido como a de que a escravidão no Brasil está extinta (o art. $1^{0}$ da Lei Áurea dispôs: é declarada extincta, desde a data desta lei, a escravidão no Brazil) são regras jurídicas, porque ou são integralmente cumpridas ou não. Contudo, quando pensamos na supressão de uma categoria de direitos que anteriormente era passível de ser adquirido, não existe um confronto direto entre os comandos dessas regras de modo que uma revogue a outra. Somente a escravidão deixa de ser permitida, mas os demais direitos subjetivos permanecem válidos. A regra da proteção aos direitos adquiridos permanece válida. Assim, o que está em jogo é a possibilidade ou não de uma norma (não pretendemos entrar aqui na questão da hierarquia dessa norma, razão pela qual supomos tratar-se de uma norma constitucional) suprimir uma determinada categoria
} 
Não é demais ressaltar que essa última hipótese aplica-se somente em casos raríssimos e, ainda que se admita que somente uma norma de ordem pública terá o condão de possibilitar a supressão de um direito adquirido, essa afirmativa não permite a conclusão de que toda norma de ordem pública será dotada dessa mesma aptidão, o que, em nossa opinião seria extremamente perigoso e contrário ao sistema.

Feitas essas considerações entendemos que o fato da maior parte das normas processuais ser dotada de preponderante interesse público ${ }^{222}$ não deve ser utilizado para diferenciá-las das demais normas em termos de direito intertemporal.

\subsubsection{Complexidade da relação jurídica processual}

Parte da doutrina entende que a complexidade da relação jurídica processual influencia o modo como a lei processual se aplica no tempo, sendo, destarte, um fator de diferenciação para o direito processual intertemporal. Normalmente os defensores dessa idéia não consideram a apontada complexidade como o único fator para justificar o estudo apartado da disciplina, mas crêem que ela deve ser levada em consideração para tanto.

de direitos de modo a afetar os direitos anteriormente adquiridos. A resposta, em nossa opinião, passa pelos valores que estão à base dessas regras e, por isso, afirmamos que ela se faz mediante a utilização do princípio da proporcionalidade. Melhor explicando, não será qualquer categoria de direitos que, uma vez suprimida, acarretará a afetação imediata dos direitos adquiridos. Suponhamos que para estimular a pesquisa científica uma Emenda à Constituição suprima os direitos autorais de obras científicas. Daí não decorre, necessariamente, que os direitos autorais anteriores deixam de existir. Para se chegar a uma solução sobre a preservação ou não dos direitos autorais anteriormente adquiridos ter-se-á que balancear o princípio da segurança jurídica com o valor contido no avanço da pesquisa.

${ }^{222}$ Quando tratamos em sentido genérico de normas de ordem pública no presente tópico estamos nos referido a leis em que o interesse público é preponderante. Optamos por utilizar essa terminologia sem adentrar nas diferenças entre leis de ordem pública e leis de direito público, porque entendemos que na maioria dos casos em que a doutrina e a jurisprudência associam a ordem pública com a eficácia imediata da lei utilizam o primeiro conceito para indicar a idéia de prevalência do interesse público contido na norma. Para maiores distinções entre os conceitos mencionados, v. FÁBIO PESSOA, Elementos para uma teoria..., pp. 79-85. 
A justificativa parte dos ensinamentos de CARNELUTTI. O autor italiano observou que o processo é uma cadeia de atos interligados que convergem para um único fim: a prolação da sentença. Justamente por isso, embora seja plenamente possível no plano teórico isolar os atos processuais deixando de considerar que um ato seja entendido como efeito jurídico de outro que Ihe é antecedente -, a coordenação prática entre eles subsistirá. E, em virtude dessa coordenação prática, a mudança da lei processual pode acarretar uma desconexão inconveniente ou uma desorientação do processo ${ }^{223}$.

Decorre dessa linha de raciocínio a assertiva de que essa coordenação entre atos de uma dada situação jurídica processual (ou entre mais de uma situação jurídica) pode acarretar atenuações na aplicação imediata da lei processual $^{224}$.

Há quem afirme, por outro lado, que o grau elevado de complexidade inerente à relação jurídica processual e a multiplicidade de situações jurídicas formadas no seu curso acarretam, muitas vezes, a necessidade de apresentar soluções casuístas para os problemas de direito intertemporal $^{225}$.

Sem dúvida alguma o fenômeno processual se difere da quase totalidade das demais relações jurídicas em decorrência de sua extrema complexidade. O número de atos praticados no processo e a existência de múltiplas situações jurídicas é certamente muito maior do que a dos mais

\footnotetext{
${ }^{223}$ Sistema de direito processual civil, vol. I, p. 168. Para evitar tais inconvenientes, anota CARNELUTTI que o legislador italiano comumente adota a técnica de tratar do direito processual intertemporal mediante disposições transitórias contidas nas leis reformadoras. Utilizamos o verbo no presente, porque o legislador italiano permanece utilizando essa técnica, como demonstram ELIO FAZZALARI, "Efficacia della legge processuale nel tempo", pp. 894-895 e GIROLAMO BONGIORNO, "Il regime transitorio: un momento critico della riforma del codice di procedura civile”, passim.

${ }^{224}$ Esse é o posicionamento de FÁBIO PESSOA, Elementos para uma teoria..., pp. 179-181, esp. p. 181.

${ }^{225}$ Nas palavras de LUCAS RISTER DE SOUSA LIMA, Direito intertemporal no processo civil, p. 97: "Segundo nos parece, certamente a característica que confere maior especificidade ao sistema processual civil, e, por isso, acaba por dificultar consideravelmente o trabalho do exegeta em relação à aplicação das leis no tempo, é a complexidade a ele imanente e, por corolário, a multiplicidade de situações jurídicas formadas ao longo de toda a sua existência, as quais acabam combinando elementos heterogêneos e de diversos matizes, dando origem à ocorrência das mais intrincadas e inusitadas circunstâncias, muitas vezes até imprevisíveis, que exigem soluções casuísticas e peculiares, sempre de conformidade com o caso concreto".
} 
intrincados contratos, mas esse fato, em si, não nos parece suficiente para diferenciar a eficácia temporal da lei processual.

Existem, tanto no processo como nas relações jurídicas de direito material, situações complexas que dependem da sucessão de atos no tempo, ou, ainda, da ocorrência de mais de uma situação para que se constituam ou se extingam.

Para que se possa dizer que a lei processual difere da lei material em função desse caráter complexo, necessário seria demonstrar que a aplicação imediata da lei ou sua ultratividade seguem padrões diferenciados para as situações jurídicas complexas ou dependentes, materiais e processuais, o que não nos parece que seja correto. A eficácia temporal da lei seguirá a mesma regra tanto nas relações jurídicas materiais como nas processuais em função do seu caráter complexo (e também nas situações dependentes ou condicionais). Se entendermos que a solução para o problema das situações complexas é a eficácia imediata da lei, respeitando os atos que detêm valor jurídico próprio, ela se aplicará tanto para uma lei processual como material.

A complexidade da relação jurídica processual traz, em nossa opinião, uma dificuldade maior para a identificação das situações jurídicas processuais $^{226}$. Ela não permite um comportamento diferenciado da lei processual no tempo, mas tão somente impõe ao intérprete um obstáculo a mais no momento de identificação de um dos principais institutos para o direito processual intertemporal, que é a situação jurídica processual.

Deve-se afastar, destarte, a afirmativa de que a complexidade das relações jurídicas processuais acarreta, muitas vezes, a solução casuísta para problemas de direito processual intertemporal. As soluções diferenciadas em função das peculiaridades dos casos concretos são

\footnotetext{
${ }^{226}$ Em sentido análogo é a observação de MARCELO ABELHA RODRIGUES, A terceira etapa da reforma processual civil, p. 12, para quem: "a farta miríade de problemas atinentes aos processos pendentes, justamente porque, como já se disse - em razão da complexidade do conceito de processo, uma entidade multifacetária - fica por vezes difícil identificar onde e quando existe uma situação jurídica consumada num feito pendente, para saber se se deve respeitar, naquele caso específico, o princípio da irretroatividade e do respeito ao direito adquirido".
} 
excepcionais, intimamente relacionada com os escopos do processo e, em qualquer caso, devem ser entendidas dentro dos poderes que o próprio sistema confere ao juiz para dirigir o processo.

\subsubsection{Autonomia da relação jurídica processual}

Não é incomum que se encontrem afirmações no sentido de que a autonomia da relação jurídica processual faz com que o direito processual tenha uma dimensão própria em matéria de direito intertemporal ${ }^{227}$.

\section{O pensamento por trás desses dizeres comumente se} embasa em uma premissa equivocada, a de que a aplicação da lei processual do tempo em que o processo é iniciado, e não do tempo em que ocorreu o fato litigioso, consiste em uma particularidade do direito processual intertemporal. Nada há nesse fato que distancie a lei processual das demais. Seu comportamento dar-se-á de igual maneira, qual seja, aplicação imediata da lei ao tempo em que os atos processuais são praticados, com respeito aos direitos adquiridos, ao ato jurídico perfeito e à coisa julgada ${ }^{228}$.

Esse aspecto da autonomia da lei processual apenas permite que o processo seja regido pela lei do seu tempo, e não pela lei do tempo em que ocorreu o litígio, mas, justamente por serem distintas e autônomas as relações processual e material, não existe aí qualquer particularidade ${ }^{229}$. Caso se

\footnotetext{
227 Segundo o entendimento de CHIOVENDA (Instituições..., $1^{\circ}$ vol., p. 86): "Se a aplicação da lei processual oferece, na prática, impressionantes particularidades em face da lei substancial, depende da já demonstrada autonomia do direito de ação e da relação processual com respeito a relação substancial; $a$ ação e a relação processual não se podem regular a não ser pela lei processual do tempo (e do lugar) em que o processo corre. Daí acontecer amiudadamente que, num mesmo processo, se apliquem leis de tempos (e lugares) diversos: a substancial à relação substancial, a processual à ação e à relação processuais”.

${ }^{228}$ Tratando do tema, afirmou ROUBIER, Le droit transitoire, p. 545, que: "Mais, dans le domaine de la procédure, le rôle du juge est différent, car ce n'est plus, à proprement parler, la situation juridique litigieuse qui est envisagée, mais bien une nouvelle situation juridique, qui est le litige lui-même; et cette situation se développe sous la direction du juge, qui doit lui donner un terme dans le jugement. Il en résulte que les lois nouvelles relatives à la procédure s'appliquent tout naturellement aux procès en cours, en vertu de la règle de l'effet immédiat des lois sur les situations en cours."

${ }^{229}$ De fato, antes que a autonomia da relação jurídica processual ganhasse ares de ponto pacífico na doutrina era muito comum que se entendesse que a lei processual era retroativa, porque sua aplicação imediata era
} 
entendesse o contrário, que a relação jurídica processual é dependente da relação jurídica substancial, aí sim haveria uma aplicação diferenciada da lei processual nova aos fatos pendentes, porque se essa aplicação fosse entendida como capaz de afetar os momentos de constituição e extinção da situação jurídica substancial, então a eficácia da lei processual seria retroativa.

Parece-nos mais correto, portanto, enxergar a autonomia da relação jurídica processual, nesse aspecto, como um fator importante na identificação da lei aplicável aos processos em andamento sem que, com isso, ela ocasione qualquer diferenciação ao modo de incidência da lei processual.

Isso não significa que a autonomia da relação jurídica processual não traga conseqüências para o direito processual intertemporal. Ela traz sim, mas não em virtude de sua eficácia imediata aos feitos pendentes.

\subsection{A relação jurídica como centro da autonomia do direito processual civil intertemporal: relação triangular e segurança jurídica}

De nossa parte, entendemos que muito do que foi dito sobre a autonomia e complexidade da relação jurídica processual trouxe elementos significativos para a compreensão das diferenças existentes entre a eficácia temporal da norma material e da processual, embora tais fatores não sejam suficientes para justificar a existência de um direito processual intertemporal.

A complexidade da relação jurídica processual e a coordenação entre os atos processuais dificulta a identificação das situações jurídicas processuais e a conseqüente compreensão do modo como uma lei pode ser ou não retroativa ${ }^{230}$.

entendida como um modo de afetar a relação jurídica material. Nesse sentido, v. GABBA, Teoria della retroattività..., vol.4, p. 424.

${ }^{230}$ Na realidade essa dificuldade decorre também da existência de corrente processual que explica a natureza do processo a partir do conceito de situação jurídica processual (v. JAMES GOLDSCHMIDT, Princípios gerais do processo civil, pp. 39-52). A existência de significados distintos para a mesma expressão pode 
Sua autonomia, por outro lado, permite que se indague sobre a aplicabilidade ou não do instituto dos direitos adquiridos à lei processual. Que a lei processual deve respeitar direitos substanciais adquiridos todos concordam. A dúvida que surge é sobre a existência ou não de direitos adquiridos de ordem processual.

Enquanto o direito processual era entendido como dependente da relação jurídica material era comum que se analisasse o modo como a aplicação da lei processual aos feitos pendentes poderia ou não ferir direitos adquiridos substanciais dos litigantes. A questão ganhou coloridos mais interessantes após BÜLLOW ${ }^{231}$ ter demonstrado a existência de uma relação jurídica própria, travada entre as partes e o juiz no processo e que se distingue da relação existente exclusivamente entre as partes no plano material. Desde então a doutrina diverge sobre a existência ou não de direitos processuais adquiridos, especialmente porque o conceito de direito adquirido foi cunhado com caráter eminentemente patrimonial.

É importante notar, ainda, que a existência de um terceiro sujeito que não faz parte da relação jurídica substancial traz também conseqüências bastante relevantes para o direito processual intertemporal. Nesse ponto aproximamo-nos dos dois aspectos fundamentais que permitem afirmar uma verdadeira autonomia do direito processual civil intertemporal: a existência de uma relação triangular entre autor-juiz, juiz-réu e autor-réu, com preponderância de relações diretas entre cada uma das partes com o juiz, e o alcance da segurança jurídica para o processo.

Se o caráter autônomo da relação jurídica processual não é, por si só, suficiente para justificar a existência de um direito processual intertemporal, sua relação de instrumentalidade com o direito material, sem dúvidas, traz conseqüências de extrema relevância para esse fim.

causar graves equívocos na compreensão do modo como uma lei processual pode ter eficácia imediata ou retroativa. Justamente por isso, voltaremos ao tema para traçar as diferenças necessárias entre os conceitos de situação jurídica processual da teoria geral do processo e do direito intertemporal no capítulo IX, abaixo.

${ }^{231}$ Teoria das exceções e dos pressupostos processual, passim. 
De fato, a partir do momento em que concebemos o direito processual como um instrumento de trabalho ${ }^{232}$, como um método do qual se utiliza o Estado para conferir aos seus cidadãos o gozo pleno de seus direitos de modo a garantir a paz social, chegamos à conclusão inafastável de que o processo não interessa exclusivamente às partes, mas também (e especialmente) àquele que irá solucionar o conflito, o juiz ${ }^{233}$.

Do ponto de vista da atividade jurisdicional os fundamentos do direito intertemporal perdem um pouco sua força original e é isso o que faz com que o direito processual civil intertemporal detenha particularidades tanto na dimensão de seus institutos como no comportamento do princípio tempus regit actum. De fato, conforme procuraremos demonstrar nos tópicos seguintes, a segurança jurídica no processo não é a mesma que existe no plano do direito material. A influência da vontade das partes também é menos relevante no plano processual, bem como a necessidade de se preservar a unidade do ordenamento.

Por outro lado, as relações diretas entre as partes no processo possuem um campo significativamente limitado, sendo mais comum que cada uma estabeleça relações diretas com o juiz.

De tudo isso resulta uma diminuição de amplitude do conceito de direitos processuais adquiridos bem como a possibilidade de controle pelo juiz, em certas situações, da eficácia imediata da lei.

\footnotetext{
${ }^{232}$ Tratando o processo como um método de trabalho ensina BEDAQUE, Efetividade do processo e técnica processual, p. 35, que: "Para solucionar as controvérsias decorrentes da não observância das normas de direito material, desenvolveu-se um método de trabalho, segundo técnicas que a experiência revelou adequadas. (...) A este fenômeno denomina-se 'processo jurisdicional', instrumento concebido pelo Estado, que dele se vale para, juntamente com as partes, obter o resultado prático desejado pelo legislador material."

${ }^{233}$ Conforme ensina DINAMARCO, A instrumentalidade do processo, pp. 77-82, a jurisdição deve ser colocada no centro da constelação de institutos processuais.
} 


\subsubsection{Análise dos fundamentos do direito intertemporal na teoria clássica}

Tanto quando se pensa no respeito aos direitos adquiridos como na necessidade de a lei prover para o futuro a primeira idéia que vem à mente é a segurança das relações jurídicas.

A segurança conferida pela proteção aos direitos adquiridos tem íntima relação com as idéias de estabilidade e confiança.

Uma vez que um cidadão adquire um direito subjetivo ele não mais deve ser passível de lhe ser subtraído por lei posterior. Se ao Estado fosse dado intervir nas relações intersubjetivas diminuindo ou subtraindo livremente a esfera de direitos de seus cidadãos, ninguém poderia se dizer seguro com relação à titularidade de um direito ${ }^{234}$. Um tal estado de insegurança seria extremamente prejudicial às organizações sociais, especialmente para os negócios, na medida em que qualquer alienação, locação, empréstimo ou doação de um direito deve ter por base a certeza de que ele não será afetado por lei posterior ${ }^{235}$.

\section{É necessário, assim, que os cidadãos detenham uma} confiança na preservação de seus direitos. Esse elemento, a que os romanos chamavam fides, também pode ser considerado como um dos componentes da segurança para explicar a proteção aos direitos adquiridos ${ }^{236}$.

\footnotetext{
${ }^{234}$ Após colocar na balança os valores progresso e segurança que estão na base da decisão política do sistema de direito intertemporal, pontua CAIO MÁRIO DA SILVA PEREIRA: "mas aceitar também que a lei atual faça tábula rasa da lei anterior e de todas as suas influências, como se a vida de todo o direito e a existência de todas as relações sociais tivessem começo no dia em que se iniciou a vigência da lei modificadora, é ofender a própria estabilidade da vida civil e instituir o regime da mais franca insegurança, enunciando a instabilidade social como norma legislativa" (Instituições..., vol. I, p. 138).

${ }^{235}$ Nesse sentido, v. MARCEL PLANIOL, Traité élémentaire de droit civil, tome 1er, n. 243, p. 113.

${ }^{236}$ SAVIGNY, explica o fundamento para a irretroatividade da lei (com respeito aos direitos adquiridos) da seguinte forma: "Em primeiro lugar, é muito importante e desejável que os cidadãos tenham uma confiança inquebrantável no domínio das leis. (...) Cada um deve, portanto, poder sentir-se seguro que os atos jurídicos por ele realizados, segundo as leis existentes, para adquirir direitos conservem no futuro sua eficácia. Em segundo lugar, não é menos importante nem menos desejável ver mantidos o estado de direito e dos bens. (...) Por último, o princípio contrário deve ser rejeitado só porque é impossível tirar dele todas as conseqüências, pois sua aplicação é necessariamente acidental, inconseqüente e por isso injusta, porquanto abrange somente certas espécies de atos jurídicos e não pode atingir outros." (Sistema do direito romano atual, vol. VIII, p. 308).
} 


\section{JOSÉ EDUARDO MARTINS CARDOZO faz objeção quanto}

à utilização da segurança jurídica como "valor histórico fundamental do direito adquirido" ao entendimento de que esse não é um valor específico do direito intertemporal. Para ele, os valores fundamentais do direito intertemporal são: a previsibilidade jurídica e a necessidade de adequação dos sistemas normativos às mutações e as novas exigências sociais. A segunda idéia não fundamenta qualquer proteção às situações jurídicas, mas é utilizada para explicar as razões que levam à mudança de legislação e que impõem, nos casos em que é possível, sua aplicação imediata às situações pendentes. Com relação à previsibilidade, entende o autor que "ao disciplinar o Direito Intertemporal o 'modus' pelo qual o efeito de duas normas que se sucedem no tempo se colocarão na realidade, o que se objetiva é que 'a priori' seja previsível qual regra regulará, em todos os seus efeitos, certos atos ou fatos que se fazem realizar na vida social"237.

Entendemos que a busca por um valor fundamental que seja específico ao direito intertemporal não é justificada. Os fundamentos do direito intertemporal podem ser comuns a qualquer outro ramo da ciência jurídica sem que isso seja um fator que thes tire a qualidade de "valores fundamentais" daquela ciência. O que diferencia o direito intertemporal dos demais ramos da ciência jurídica é a existência de um sistema próprio, com objeto particular e princípios e regras que atuam de maneira específica e não seu fundamento ${ }^{238}$. Não fosse assim, ademais, a previsibilidade também está associada à idéia de segurança jurídica ${ }^{239}$ e não é fundamento exclusivo do direito intertemporal.

${ }^{237}$ Da retroatividade..., pp. 1021-106, esp. pp. 104-105. Para que se faça justiça ao pensamento do autor é necessário frisar que ele entende que a segurança é um valor intrínseco a toda ordem jurídica e, assim, também ao direito intertemporal.

${ }^{238}$ MIGUEL REALE, Filosofia do direito, pp. 61-64, diferencia o direito das demais ciências a partir da demonstração de que existe um sistema próprio do direito, formado pelo entrosamento lógico dos seus tipos, leis e princípios. KARL LARENZ, após traçar linhas gerais do modo como a ciência jurídica pode ser dividida em disciplinas diferentes, justifica a autonomia da Jurisprudência como ciência normativa ao entendimento de que "se a Jurisprudência se compreende a si própria como <ciência normativa>, tal não pretende significar que ela mesma dê normas, que ponha em vigor normas jurídicas. Antes, que se compreende a si própria em princípio como um sistema de enunciados sobre o Direito vigente" (Metodologia da ciência do direito, pp. 261-270, esp. p. 270).

${ }^{239}$ Conforme ensina JOSÉ AFONSO DA SILVA, “Constituição e segurança jurídica”, p. 17, “A Constituição reconhece quatro tipos de segurança jurídica: a segurança como garantia; a segurança como proteção dos direitos subjetivos; a segurança como direito social e a segurança por meio do direito". Desses quatro conceitos, o que se refere propriamente ao direito intertemporal é o segundo (proteção dos direitos subjetivos). Após associá-la à necessidade de “assegurar a estabilidade dos direitos adquiridos" o 
Melhor seria, então, acrescentar a idéia de previsibilidade às de estabilidade e certeza para explicar o conteúdo da segurança jurídica como fundamento da proteção aos direitos adquiridos.

Saindo do campo dos direitos adquiridos e pensando na irretroatividade da lei - considerada isoladamente e sem qualquer relação com esse instituto - vemos que ela tem por fundamento a lógica, no sentido de que a regulamentação dos fatos jurídicos deve obedecer a lei do tempo em que eles ocorreram $^{240}$. Alguns autores chegam a afirma que a irretroatividade da lei decorre de uma razão natural ${ }^{241}$, mas esse pensamento é contestado por grande parte da doutrina que não admite as premissas jus-filosóficas que se embasam no direito natural à irretroatividade da lei ${ }^{242}$.

Independentemente da corrente filosófica a que se filie, é certo que ao regulamentar uma determinada conduta humana, um modo como as pessoas devem se comportar frente a determinadas situações da vida, a lei deve dispor para o futuro e não para o passado. Justamente por isso é que, do ponto de vista lógico a lei não pode ser retroativa, embora seja possível, em determinadas situações que o legislador politicamente decida, editar leis com esse caráter ${ }^{243}$.

constitucionalista paulista afirma, citando JORGE REINALDO VANOSSI (El Estado de Derecho en el Constitucionalismo Social) que: "A segurança jurídica dos direitos subjetivos consiste no 'conjunto de condições que tornam possível às pessoas o conhecimento antecipado e reflexivo das conseqüências diretas de seus atos e de seus fatos à luz da liberdade reconhecida' " (p.19).

${ }^{240}$ Para CLÓVIS BEVILÁQUA, Teoria geral do direito civil, p. 19: "O princípio da não retroatividade das normas legislativas, que tem sido um dos pontos mais obscurecidos pela discussão jurídica, affirma, simplesmente, não que a lei se referirá exclusivamente aos actos futuros, o que equivaleria apenas a mostrar o accôrdo existente entre a logica e a legislação, mas que as consequencias dos actos realisados no dominio da lei anterior não devem ser attrahidas para o imperio da lei nova, excepto si estiverem em opposição manifesta aos principios e regras estabelecidas pela nova ordem juridica”. É relevante notar nesses ensinamentos que, quando o autor isola o princípio da não retroatividade à projeção de efeitos da lei aos atos futuros, o fundamento para essa irretroatividade passa a ser uma questão de acordo entre a lógica e a legislação.

${ }^{241}$ Esse é o pensamento de LIMONGI FRANÇA, A irretroatividade das leis.., p. 8.

${ }^{242}$ V. JOSÉ EDUARDO MARTINS CARDOZO, Da retroatividade da lei, p. 50. Em interessante passagem SÉRGIO RESENDE DE BARROS, alerta para o risco da naturalização, que considera um estratagema da ideologia (Contribuição dialética para o constitucionalismo, pp. 90-91). Segundo o Professor das Arcadas, a explicação de um fenômeno como algo natural pode eclipsar o seu caráter social e histórico, auxiliando a dominação da ideologia que está por trás desse entendimento.

${ }^{243}$ Nesse sentido, FRANCESCO LA VALLE entende que é inexato falar em normas (prescriozioni giuridiche) retroativas, porque "Prescrittività e retroattività sono concetti incompatibili: le vere prescrizioni non possono essere retroattive, e quelle veramente retroattive non possono essere prescrizioni" ("Sucessione di Leggi”, pp. 636-637). No entendimento do autor, a lei retroativa é uma proposição revestida da forma de 


\subsubsection{Fundamentos do direito intertemporal na teoria objetivista}

A corrente objetivista não se fundamenta na proteção aos direitos adquiridos, mas na proteção contra a retroatividade da lei e no princípio da sua eficácia imediata.

A justificativa para a irretroativadade da lei passa pelos dois fundamentos apresentados pela doutrina subjetivista, quais sejam, a segurança jurídica e a lógica ${ }^{244}$. De diferente essa corrente traz os fundamentos para a eficácia imediata da lei e para a sobrevivência da lei antiga (ultratividade da lei).

O princípio de que a lei deve aplicar-se imediatamente às situações jurídicas pendentes pode ser explicado a partir da idéia de progresso em relação à lei anterior. A premissa fundamental desse entendimento é a de que, sendo a lei a expressão da vontade geral da nação, ela representa o melhor meio de regulamentar as situações que se encontram sob seu domínio. Resulta daí que, quanto maior for o seu âmbito de aplicação, melhor será, o que impõe a compreensão de que, na ausência de disposição contrária deve-se conferir eficácia imediata às leis ${ }^{245}$.

ROUBIER criticou esse ponto de vista afirmando não ser exata a relação entre o progresso que a nova lei permite alcançar e sua melhor

lei que é jurídica em virtude da sua relação com outra proposição prescritiva a que ela se refere (que teve sua eficácia afetada pela proposição retroativa).

${ }^{244}$ Com a ressalva que a segurança jurídica não terá relação com a proteção individual dos direitos subjetivos, mas com o caráter de certeza e previsibilidade. V. a propósito PLANIOL, Traitè élémentaire..., tome $1^{e r}$., n. 260, p. 121 ; COVIELLO, Manuale di diritto civile italiano, parte generale, p. 108; ROUBEIR, Le droit transitoire, pp. 223-224; J. J. GOMES CANOTILHO e VITAL MOREIRA, Constituição da República Portuguesa anotada, p.153.

${ }^{245}$ Nesse sentido COLIN e CAPITANT analisam o fundamento da regra da não retroatividade da lei segundo as doutrinas individualistas e sociais. Para a primeira, o fundamento essencial é a proteção do homem e de sua liberdade, no sentido de que o indivíduo não pode ser submetido à lei e alienar sua liberdade, a não ser que ele haja consentido com isso expressa ou tacitamente. Com relação às doutrinas sociais, afirmam que elas dão menos importância à regra da não-retroatividade, acentuando a necessidade de progresso social. Tais doutrinas proclamam que toda lei nova é presumivelmente melhor que a antiga, e, por isso, ela deve se aplicar ao máximo de fatos e atos, mesmo àqueles que sejam anteriores a sua promulgação (Traité de droit civil, tome 1er., p. 149) 
aptidão para o direito transitório. Observou ele que o fato de a lei nova representar um avanço para a sociedade não significa que ela necessariamente será melhor para reger as situações pendentes quando de sua entrada em vigor. Para o Professor de Lyon, a apreciação do valor de uma legislação do ponto de vista de sua capacidade para regulamentar determinadas situações jurídicas não comporta qualquer julgamento concernente ao valor de sua aplicação às situações em curso ${ }^{246}$.

Em sua opinião, o fundamento para admissão de um princípio de eficácia imediata da lei está na submissão ao regime da lei e, por conseqüência direta, na unidade da legislação do país ${ }^{247}$.

Quanto ao princípio oposto, qual seja o da sobrevivência da lei antiga, ou ultratividade da lei, é necessário antes de mais nada relembrar que ele se aplica às situações contratuais e não às situações jurídicas decorrentes da lei.

Parte da doutrina entende que esse fenômeno se justifica em função do respeito à vontade individual. A matéria tratada no contrato é uma regulamentação concreta de uma situação individual e, justamente por isso, a lei que dispõe em termos gerais e abstratos não poderia alcançá-las ${ }^{248}$. ROUBIER critica esse ponto de vista afirmando que a partir dele não se chega a uma conclusão razoável sobre qual lei será aplicada para reger as lacunas do contrato, já que nesses casos não se poderia afirmar que existe uma situação individual com caráter especial e variável segundo um ato de vontade, de modo a afastar a incidência da lei ${ }^{249}$. A ausência dessa situação especial acarretaria a aplicação imediata da lei, o que é contrário ao seu entendimento.

\footnotetext{
${ }^{246}$ Le droit transitoire, p. 341.

${ }^{247}$ Le droit transitoire, pp. 345-347. V. a propósito tópico 3.9, acima.

${ }^{248}$ DUGUIT, Traitè de droit constitutionel, II, analisa o problema do direito intertemporal a partir dos atos jurídicos e das situações jurídicas. Quanto aos primeiros, a lei que deve regê-los é a do tempo em que foram praticados (pp. 231-238). Com relação às situações jurídicas, subdivide-as em subjetivas e objetivas e afirma que para a primeira a regra será a manutenção da lei do momento em que ela foi constituída, porque essas são criadas por um ato estranho à lei e, assim, la loi nouvelle ne peut donc toucher une situation juridique subjective parce qu'elle ne peut toucher les actes individuels antérieurs à elle (pp. 238-239).

${ }^{249}$ Le droit transitoire, pp. 386-387.
} 
Outra explicação para a ultratividade da lei nas situações jurídicas contratuais aponta para a existência de um contrato tácito, segundo o qual as partes pretendem que a regulamentação legal do contrato deverá seguir a lei do tempo em que ele foi celebrado. A construção é novamente criticada por ROUBIER que, apesar de louvar o fato de ela enfrentar diretamente o coração do problema (porque trata do regime legal do contrato), entende como um exagero de linguagem a afirmação de existência de um contrato tácito. Em sua opinião, o homme de la rue não tem conhecimento de todas as particularidades regidas pela lei quando firma um contrato, donde se conclui que não é possível afirmar que ele tenha feito um contrato tácito para a manutenção integral desse regime que ele sequer conhece. Por outro lado, a explicação desse contrato tácito se torna mais insustentável do ponto de vista das leis imperativas que limitam a liberdade dos contratantes. Elas não podem ser entendidas como uma expressão tácita da vontade dos contratantes se têm por objeto justamente limitar sua liberdade para contratar.

Feitas essas observações, ROUBIER fundamenta a sobrevivência da lei revogada a partir da noção de diversidade, fenômeno oposto ao que acontece com a eficácia imediata da lei para reger as situações jurídicas decorrentes da lei em que a idéia central é a unidade.

Conforme exposto no tópico 3.9 acima, esse pensamento parte do entendimento de que a diferenciação entre os indivíduos feita por meio do contrato é uma necessidade capital das sociedades humanas. Assim, sendo todos são iguais perante a lei, os indivíduos somente conseguem se diferenciar juridicamente uns dos outros por meio do contrato.

Segundo expõe o Professor francês, do consentimento que o legislador dá para que as partes contratem surge um imenso campo de escolhas para elas, que criam, assim, um número extremamente diferenciado de situações contratuais. E esses contratos constituem um ato de previsão, em que os contratantes esperam que as cláusulas por eles livremente estipuladas sejam respeitadas pela lei. Mesmo no campo em que a lei não confere liberdade para as partes contratarem, ou seja, nas disposições de caráter imperativo que limitam a 
disponibilidade dos contratantes, a lei nova que altere tais disposições somente poderá surtir efeito para os contratos concluídos após a sua vigência, porque a vontade das partes no momento de elaboração do contrato deverá ser respeitada. No entender do autor, o contrato "constitui um bloco de cláusulas indivisíveis que nós só podemos apreciar sob a luz da legislação sob a qual ele se passou"250.

Nota-se daí que, apesar de não concordar com as teorias precedentemente citadas, ROUBIER utiliza elementos delas para explicar o fundamento para a sobrevivência da lei revogada para reger os contratos em curso, dado que leva em consideração a vontade das partes contratantes e suas expectativas sobre a manutenção do regime legal vigente no momento da celebração do contrato. Resumidamente, o fundamento para o princípio da ultratividade pode ser entendido como a proteção da diversidade jurídica, com a preservação da vontade dos contratantes tanto no que diz respeito às cláusulas contratuais, como quanto à manutenção de um único regime legal aplicável ao contrato.

\subsubsection{A segurança jurídica no direito processual civil intertemporal}

Bem delimitados os fundamentos do direito intertemporal nas teorias subjetivista e objetivista torna-se possível compreender o que existe de especial no regime do direito processual civil intertemporal.

De início cumpre observar que a segurança jurídica no processo pode ser analisada sob dois enfoques distintos: do ponto de vista das partes e do juiz.

A doutrina comumente analisa a segurança jurídica no processo a partir do primeiro ponto de vista e afirma, assim, que o formalismo é o

${ }^{250}$ Le droit transitoire, pp. 391-393. 
meio pelo qual se confere às partes um processo seguro ${ }^{251}$. Esse formalismo não se refere somente às exigências intrínsecas e extrínsecas para a prática de atos, mas a todo o modelo de participação dos sujeitos processuais no curso do processo $^{252}$. Inclui-se aí tanto a forma dos atos processuais e do procedimento, como as garantias do devido processo legal, em especial o contraditório, a isonomia e a imparcialidade do juiz.

Ao associar as idéias de formalismo com segurança jurídica o que se costuma afirmar é que as exigências formais constituem uma garantia das partes contra arbítrios do juiz ${ }^{253}$. O desenho previamente traçado pelo legislador para a prática de atos e a seqüência do procedimento permite que os litigantes saibam de antemão quais serão as oportunidades que terão para participar, o modo pelo qual terão que efetuar essa participação, e qual será o caminho percorrido no procedimento até o final do processo ${ }^{254}$. A primeira idéia que se tem, portanto, é a de previsibilidade ${ }^{255}$. É esse saber prévio que permite às

\footnotetext{
${ }^{251}$ Para ARRUDA ALVIM, Manual de direito processual civil, vol. I, p. 468: “O formalismo, na prática de determinados atos, é essencial para a convivência social ordenada e, portanto, para uma vivência jurídica estável, a fim de que o Direito se apresente certo e seguro."

${ }^{252}$ CARLOS ALBERTO ALVARO DE OLIVEIRA, Do formalismo no processo civil, pp. 5-7, distingue a forma em sentido estrito, que é o invólucro do ato processual, da forma em sentido amplo, que compreende também as condições de lugar e tempo em que o ato é práticado. A essas condições o Professor da Universidade Federal do Rio Grande do Sul denomina formalidades. Quanto ao formalismo, explica que esse engloba não só a forma em sentido estrito e as formalidades como especialmente "a delimitação dos poderes, faculdades $e$ deveres dos sujeitos processuais, coordenação de sua atividade, ordenação do procedimento $e$ organização do processo, com vistas a que sejam atingidas suas finalidades primordiais”. BEDAQUE prefere denominar esse conjunto de elementos do processo de técnica processual (Efetividade do processo $e$ técnica processual, pp. 91-93).

${ }^{253}$ Tratando das diferenças entre os regimes da legalidade e da instrumentalidade das formas ROQUE KOMATSU, Da invalidade no processo civil, p. 81 observa que: "Se se quer escapar ao inteiro arbitrário da parte do juiz, é indispensável que o legislador determine ele mesmo as formalidades, que serão sancionadas pela nulidade, aquela que só será pronunciada nos casos expressamente especificados pela lei: 'pas de nullité sans texte'."

${ }^{254}$ Leciona JOSÉ FREDERICO MARQUES, Manual de direito processual civil, vil. 1, p. 321: “A lei impõe seus modelos aos atos processuais para que estes, com a forma assim preestabelecida, atinjam sua finalidade, tenham recepção adequada, e haja ordem, regularidade e clareza na sua produção, durante o curso do processo. A observância das formas constitui, portanto, fator de regularidade procedimental, garantindo às partes um perfeito conhecimento do curso do processo e dos atos que nele se praticam."

${ }^{255}$ Após observar que "o direito traça um caminho prévio para os sujeitos do processo, com base no qual estes deverão ter a certeza de atuar validamente. Especifica de antemão as conseqüências a serem geradas, nas hipóteses de desvio desse caminho (invalidade) e concede expectativas em relação ao procedimento e à relação jurídica processual, evitando tumultos e surpresa”, conclui MARCELO PACHECO MACHADO, Incerteza e processo: um estudo direcionado às técnicas recursais e à ação rescisória, pp. 21-22 que "cumprindo seu dever de segurança jurídica, o formalismo assegura um mínimo de previsibilidade (ao procedimento e à relação jurídica processual) e, ao mesmo tempo, fomenta o respeito às garantias constitucionais do processo, assegurando o devido processo legal.”
} 
partes que pratiquem seus atos em conformidade com as exigências legais, que Ihes dá segurança de saber que o juiz está seguindo o caminho correto.

Por outro lado, de nada adianta um processo extremamente previsível se ele não for equilibrado. Não existe segurança sem que haja condições de igualdade para as partes defenderem seus interesses no processo. Se uma das partes fosse mais forte no processo, haveria uma tendência maior a que se sagrasse vencedora e isso seria um fator de previsibilidade quanto ao resultado do processo, mas essa não é uma previsibilidade desejada. Todo aquele que se socorre do judiciário para fazer valer um direito de que acredita ser titular espera que, no mínimo, tenha igualdade de condições para convencer o juiz de que está com a razão. Esse anseio por condições de igualdade não pode ser desconsiderado, porque a parte somente se sentirá segura no processo se acreditar que litiga com as mesmas armas de seu adversário. Assim, o formalismo deve garantir não só a previsibilidade como a paridade de armas entre os litigantes ${ }^{256}$.

Outro aspecto que não pode ser esquecido quando se pensa em segurança jurídica no processo é a estabilidade. Diz-se com freqüência que é necessário que o processo ponha um fim definitivo às crises de direito material que Ihe são dirigidas ${ }^{257}$. Essa necessidade de definição é extremamente relevante para a sociedade, sendo raríssimos os casos de sentença não dotada de aptidão para formação da coisa julgada material ${ }^{258}$.

\footnotetext{
${ }^{256}$ Nessa perspectiva, o contraditório assume uma posição central dentro do sistema processual, não só por garantir a igualdade entre as partes como por permitir ao juiz que dialogue com elas e busque o maior número de elementos possíveis para sua decisão sem comprometer sua imparcialidade. Nesse sentido, v. NICOLA PICARDI, "Il principio del contraditorio”, pp. 677-681.

${ }^{257}$ Conforme ensina BEDAQUE, Direito e processo, pp. 118: "As variações quanto aos limites objetivos $e$ subjetivos da imutabilidade da decisão, verificadas em função da natureza e de circunstâncias da relação material, devem-se ao fato de que a utilidade prática da coisa julgada reside na estabilização dessas situações da vida postas pela parte como objeto do processo. A imutabilidade dos efeitos da decisão judicial irá assegurar a eficiência do processo, como instrumento de pacificação social. Sem essa imutabilidade, restariam frustrados os escopos da jurisdição". Em sentido análogo BARBOSA MOREIRA, "Ainda e sempre a coisa julgada", p. 10, é taxativo: "A coisa julgada é instituto de função essencialmente prática que existe para assegurar estabilidade à tutela jurisdicional dispensada pelo Estado".

${ }^{258}$ Acerca dessa possibilidade observa BARBOSA MOREIRA, “Coisa julgada e declaração”, pp. 85-86, que o cân. 1.903 do Codex Iuris Cononici dispõe que "nunquam transeunt in rem iudicatam casae de statu personarum".
} 
Diante dessas observações poder-se-ia supor que a amplitude da segurança jurídica no processo é maior do que nas relações jurídicas de direito material. Mas essa suposição não é correta.

De fato, se é verdade que a doutrina costuma associar a idéia de formalismo com a necessidade de conferir previsibilidade ao processo e conferir segurança jurídica para as partes, não é menos correto que essa exigência de previsibilidade é balanceada com os escopos do processo ${ }^{259}$. No nosso sistema esse equilíbrio é alcançado pelo princípio da instrumentalidade das formas $^{260}$, que possibilita ao juiz deixar de aplicar uma exigência formal quando a finalidade para a qual ela havia sido criada for alcançada por outros meios, ou nos casos em que a ausência da forma não ocasione prejuízo para a parte ${ }^{261}$ que dela se beneficiaria.

A doutrina costuma afirmar que a segurança jurídica é relativizada em virtude da necessidade de se alcançar um resultado justo, que se aproxime ao máximo da verdade real. A forma pode ser entendida como um fator de segurança, mas o excesso de formalismo aprisiona e distancia o processo de seus escopos ${ }^{262}$. Tais afirmações nos parecem inteiramente corretas. Enxergando sob outro ângulo, talvez se chegue à conclusão de que a segurança jurídica no

\footnotetext{
${ }^{259}$ Nas palavras de MARCELO PACHECO MACHADO, Incerteza e processo..., p. 25: "A despeito de extremamente relevante, a técnica é apenas meio e não fim em si mesmo; é instrumento dos escopos do processo e , por isso, se legitima pela capacidade de permitir resultados justos.”

260 Em estudo curto, porém bastante aprofundado, GALENO LACERDA demonstra com maestria a relevância do princípio da instrumentalidade das formas para o direito processual brasileiro e conclui que sua incorporação pelo Código de Processo Civil tornou nosso sistema profundamente antiformalista ("O Código e o formalismo processual”, passim).

${ }^{261}$ Finalidade e ausência de prejuízo são conceitos distintos que se equivalem na teoria das nulidades. Diz-se que a finalidade da forma foi alcançada quando por um meio diferente ao previsto pelo legislador chega-se ao mesmo resultado. Assim, se a intimação da parte contiver um vício, mas ela comparecer em juízo e tomar ciência da necessidade de praticar um ato, a finalidade foi alcançada e o vício sanado. A ausência de prejuízo pode ocorrer mesmo sem a sanatória do vício. Caso haja vício na intimação do autor para apresentar alegações finais, mas o juiz se convença de que ele tem razão e julgue a demanda integralmente procedente, não há porque refazer a intimação e abrir vista para a prática de um ato que tornou-se desnecessário. O vício permanece, mas, por não ter havido prejuízo, ele se torna irrelevante. Embora os conceitos sejam distintos, para a teoria das nulidades eles se equivalem, pois tanto um como o outro são suficientes para impedir que se invalidade um ato viciado. Nesse sentido, v. por todos BEDAQUE, Efetividade do processo..., p. 437.

${ }^{262}$ De maneira bastante lúcida, FERNANDO DA FONSECA GAJARDONI, Flexibilidade procedimental (um novo enfoque para o estudo do procedimento em matéria processual), p. 100, após discorrer sobre a importância do formalismo para a segurança no processo, faz a seguinte ponderação: "são as normas do procedimento as que submetem a disciplina do processo, sinalizando os preceitos a utilizar, estabelecendo a ordem das atuações, medindo em unidades de tempo sua direção. Todas essas regras são técnicas, quer dizer, vêm concebidas em função de sua utilidade para o processo. Exatamente por isso 'a experiência aconselha a mudá-las quando sua utilização torna estéril e dissipa os fins do processo"”.
} 
processo não pode ser entendida somente do ponto de vista dos sujeitos parciais, mas deve ser analisada também da ótica do juiz.

As partes têm necessidade de previsibilidade para que possam atuar em defesa de seus interesses no processo. Ao juiz, entretanto, interessa sobremaneira a colheita de elementos para que possa ter segurança ao solucionar a lide. Se a atividade jurisdicional ficar muito limitada no que diz respeito às possibilidades de ouvir as partes e de realizar provas, o juiz poderá ser facilmente induzido em erro. Julgará sem convicção e com alto grau de possibilidade de proferir uma sentença injusta. Para que a atividade jurisdicional seja segura é necessário que o juiz tenha poder de dirigir o processo na busca do maior número de elementos possíveis ao seu convencimento ${ }^{263}$.

O entendimento geral da segurança jurídica compreende os dois pontos de vista e impõe sua utilização temperada pelas exigências das partes e do juiz, do que resulta a aplicação do princípio da instrumentalidade das formas.

Em termos práticos pode-se dizer que a previsibilidade garantida às partes tem muito mais relação com o modo próprio delas atuarem, e da necessidade de serem informadas com antecedência acerca das conseqüências decorrentes de sua não atuação (ou da sua atuação em desconformidade com o modelo legal), do que com direitos provenientes da não atuação da parte contrária.

A parte não pode ser surpreendida por não ter praticado um determinado ato que a lei não exigia, ou por ter deixado de cumprir qualquer formalidade que não estivesse claramente estipulada em algum texto legal. Disso não resulta que ela tenha direito a exigir o estrito cumprimento de todas as formalidades legais pela parte adversa, porque essas formalidades somente são

\footnotetext{
263 JOSÉ CARLOS BAPTISTA PUOLI, Os poderes do juiz e as reformas da lei processual civil brasileira, p. 88, relaciona o maior conhecimento do juiz a respeito das circunstâncias da causa, com o aumento de segurança para as partes e o Estado, afirmando que esse aumento de conhecimento "garantiria maior segurança aos interessados e ao Estado no que toca à certeza de que o ato jurisdicional final corresponderia à correta aplicação da lei”.
} 
exigidas para algum fim determinado. O prejuízo, portanto, que não pode ocorrer é ao contraditório e à isonomia ${ }^{264}$ e não a uma suposta posição de vantagem que a parte alcançaria caso o juiz se mantivesse estritamente fiel às exigências legais ${ }^{265}$.

Tanto a previsibilidade como a estabilidade ${ }^{266}$ sofrem conseqüências do temperamento entre as exigências de segurança para as partes e para o juiz no processo, o que diminui sobremaneira seu espectro se comparado com as relações jurídicas de direito material.

\footnotetext{
${ }^{264}$ Para BEDAQUE, Efetividade do processo..., p. 51: "O sistema processual não deve ser concebido como uma camisa-de-força, retirando do juiz a possibilidade de adoção de soluções compatíveis com as especificidades de cada processo. As regras do procedimento devem ser simples, regulando o mínimo necessário à garantia do contraditório mas, na medida do possível, sem sacrifício da cognição exauriente". Em outro trecho de sua obra tratando especificamente da teoria das nulidades, o Professor das Arcadas esclarece com exatidão qual o verdadeiro conteúdo da segurança jurídica que se deve obter mediante a observância da técnica processual: "Afinal de contas, em sede processual o interesse público reside na sua finalidade externa, representada pela eliminação da crise no plano material. Desde que esse resultado seja obtido mediante instrumento dotado do mínimo de segurança, em que foram regulados o contraditório e a ampla defesa, qualquer vício deixa de ser importante, incidindo, então, os princípios da ausência do prejuízo e da economia. Assegurada a participação efetiva dos sujeitos do processo - entendida esta como aptidão para influir na formação do resultado -, nenhum desvio formal pode constituir óbice a que a sentença produza seus efeitos naturais no plano material" (p. 442).

${ }^{265}$ Em sentido contrário GOLDSCHMIDT defende a idéia de que "as expectativas de uma vantagem processual podem ser comparadas aos direitos relativos, porque há, por parte do juiz, vinculação de satisfazê-las" (Princípios gerais do processo civil, p. 45). O ponto de vista do Professor da Universidade de Berlim é extremamente coerente com o seu modo de pensar, que via no princípio do dispositivo (entendido como aquele que supõe que em Direito Processual Civil pesa sobre as partes o ônus de proporcionar os fundamentos da sentença mediante seus atos de postulação) o princípio dominante e de mais interesse para o processo civil, (Direito processual civil , p. 81) e encarava o processo como uma guerra em que o litigante mais hábil deveria se sagrar vencedor (Princípios..., pp. 39-52, esp. p. 49). Esse modo de pensar não se afina com os ideais de instrumentalidade do processo e com o seu escopo de pacificação social com justiça (DINAMARCO, A instrumentalidade..., p. 161). Em ilustração bastante feliz BARBOSA MOREIRA compara os sistemas que privilegiam o litigante mais hábil com duelo judiciário, e aproxima desse modelo o sistema adversarial presente nos países do common law cujo traço principal é o controle e configuração do modo de litigar pelas partes e seus advogados ("Duelo e processo", esp. pp. 179-184).

${ }^{266}$ Em trabalho anterior apresentado para obtenção do grau de mestre por está faculdade tivemos oportunidade de analisar a relação entre as preclusões e a estabilidade dos atos processuais e concluímos que as preclusões referem-se à estabilidade da relação jurídica processual enquanto que a coisa julgada vincula-se mais diretamente à segurança jurídica da relação jurídica de direito material, sendo essa muito mais importante para o sistema, porque a finalidade das preclusões como meio de garantir a estabilidade da relação jurídica processual é bastante relativa, por vincular-se às idéias de coerência e lógica que muitas vezes são deixadas em segundo plano pelo próprio sistema (Preclusão e a instrumentalidade do processo, pp. 126-129 e 136-137).
} 


\subsubsection{Fundamento da eficácia imediata da lei processual}

Conforme expusemos no tópico 5.3.2, acima, além do princípio da irretroatividade da lei, a teoria objetivista se preocupa em definir os casos em que a lei deve ter aplicação imediata para reger as situações pendentes e aqueles em que ocorrerá a sobrevivência da lei antiga.

A eficácia imediata da lei é aplicável às situações jurídicas dela decorrentes (não contratuais). Seus fundamentos são a maior eficiência para reger as situações que abstratamente regula e a necessidade de conferir unidade ao ordenamento.

O segundo aspecto, quando afirmado de maneira independente da segurança jurídica parece realmente pouco relevante para o processo. De fato, no plano processual a unidade do ordenamento é necessária para conferir previsibilidade às partes, conforme afirmado acima. As leis processuais são gerais e igualmente aplicáveis para todos os processos não por uma questão de unidade, mas para possibilitar às partes que tenham prévio conhecimento de como ele está regrado. Não cumprindo essa finalidade, seria plenamente aceitável, e em alguns casos até mesmo recomendável, que o processo fosse adaptável, tanto em função de particularidades da relação jurídica de direito material ${ }^{267}$, como sócio-ambientais relativas à condições econômicosociais dos litigantes ou ao local em que estiver instalado o juízo competente para julgar a demanda ${ }^{268}$.

\footnotetext{
${ }^{267}$ Exemplo interessante de adaptabilidade do procedimento é a previsão contida na Lei de Arbitragem (Lei Federal $n^{\circ} 9.307$ de 23 de setembro de 1.996) que permite às partes regulamentar a forma do procedimento, aceitar as regras de um órgão arbitral institucional ou delegá-la ao próprio árbitro (art. 21). Com relação à primeira hipótese, após demonstrar que essa previsão é bastante incomum na cláusula compromissória, demonstra CARMONA, Arbitragem e processo, p. 249, que ela pode ser uma boa saída para as arbitragens instituídas por meio de compromisso arbitral. Nas palavras do Professor das Arcadas: "sabendo-se exatamente qual o objeto do processo arbitral e quem serão os árbitros, podem as partes estabelecer confortavelmente um procedimento especial para resolver seu litígio que seja adequado aos problemas que o árbitro enfrentará, levando em consideração a necessidade de deslocamentos, a dificuldade técnica e jurídica do tema a ser tratado, a necessidade ou não de produção de provas constituendas, o tempo em que desejam seja proferida a decisão, entre tantos fatores relevantes”.

${ }^{268}$ Defendendo a descentralização para permitir que os Estados e o Distrito Federal legislem em matéria processual e procedimental, afirma FERNANDO GAJARDONI, Flexibilidade procedimental..., pp. 77-79 que essa iniciativa não fere o princípio da isonomia, mas, ao contrário "este tratamento diferenciado vem em
} 
Com relação ao primeiro aspecto apontado - maior eficiência da lei processual nova para reger os feitos pendentes -, deve-se admiti-la com ressalvas. A lei nova representa um avanço da sociedade, um modo novo com o qual os cidadãos pretendem ver regidas as situações jurídicas abstratamente previstas na norma. Mas o alerta de ROUBIER não pode ser desconsiderado. Não é porque a lei nova representa um avanço que ela necessariamente terá maior aptidão para reger as situações pendentes. Para o direito processual esse aviso deve ser entendido conjuntamente com a observação de CARNELUTTI sobre a possível desconexão que pode advir da utilização de uma nova lei para a relação jurídica processual, que é bastante complexa e composta de uma série de atos coordenados para um único fim.

A eficácia imediata da lei processual fundamenta-se, assim, na idéia de progresso que ela pode trazer para o processo. Resta verificar, nos casos práticos em que esse progresso não seja possível, se o juiz pode ou não deixar de aplicar a lei nova e, em caso positivo, quais são os limites para essa atuação ${ }^{269}$.

Deixamos de abordar as hipóteses em que a sobrevivência da lei revogada se impõe, porque, como visto, eles se referem às situações contratuais. Embora sejam excepcionais os casos em que as partes podem transigir sobre matéria processual, entendemos que o fundamento para a manutenção da regra jurídica nesses casos, será o direito adquirido. Voltaremos ao tema no capítulo VII, abaixo.

favor da isonomia, e não contra ela. Possibilita que nos mais diversos rincões do país jurisdicionados recebam tratamento igualitário conforme suas igualdades, e não tratamento igualitário tendo realidades completamente desiguais" (p. 78).

${ }^{269} \dot{E}$ interessante notar que o legislador italiano parece ter maior consciência dos possíveis problemas que a pura e simples aplicação imediata da lei processual pode acarretar, e, com isso, costuma temperar essa aplicação imediata por meio de regras transitórias. Tratando dessas regras na reforma do Código de Processo Civil ocorrida na Itália no início dos anos 90, GIROLAMO BONGIORNO pontua que o critério inspirador do legislador italiano foi o de evitar uma brusca passagem de um rito ao outro e, "pur tenendo fede al principio generalmente accolto che la procedura obbedisce alla legge del suo tempo, ha previsto alcune eccezioni dirette ad ovviare agli inconvenienti cui avrebbe dato luogo la rigida applicazione della regola tempus regit actum" (Il regime transitorio: un momento critico della riforma del codice di procedura civile", p. 1.191). 


\subsection{Segurança jurídica, eficácia imediata da lei e a autonomia do direito processual civil intertemporal}

Das diferenças existentes entre os fundamentos do direito intertemporal no direito processual e da particularidade de sua relação ser formada entre três sujeitos, com um deles inserido no meio e acima dos demais, decorre a autonomia do direito processual civil intertemporal.

A primeira diferença, e certamente a mais marcante, é a amplitude do princípio da segurança jurídica, que no plano processual é muito mais reduzida. Como vimos, a segurança jurídica no processo deve ser analisada tanto a partir do interesse das partes em ter um caminho seguro para trilhar, como do juiz, que precisa de um instrumento que Ihe confira segurança para decidir.

Daí resulta que a preservação da estabilidade de determinadas situações jurídicas tem valor muito mais relativo, sendo equivocado associar toda e qualquer situação consolidada com direitos das partes no processo $^{270}$. Em outras palavras, se o processo ainda fosse entendido como um contrato, ou um quase contrato ${ }^{271}$, o âmbito de direitos processuais conferidos às partes seria muito maior e teria relação não somente com o modo de atuar da própria parte, como, ainda, do de seu adversário ${ }^{272}$.

\footnotetext{
${ }^{270}$ Em sentido contrário, DINAMARCO afirma que "com a realização de atos e ocorrência de fatos ao longo do procedimento que vai da propositura da demanda inicial até a sentença que põe fim a ele, novas situações jurídicas vão se criando e outras se extingüindo. Essas situações caracterizam-se como direitos processuais adquiridos, tomada essa locação no amplíssimo sentido tradicional de situações jurídicas consumadas” (Instituições de direito processual civil, vol. I, p. 99). Para fazer justiça ao pensamento do autor é importante mencionar que a alusão aos direitos processuais adquiridos nessa passagem está mais associada à idéia de irretroatividade da lei do que propriamente a de proteção a um direito processual subjetivo da parte, que o autor sequer reconhece como possível de existir (v. Instituições..., vol. II, pp. 210-211). Os direitos processuais adquiridos parecem mais verdadeiramente relacionados com os institutos bifrontes, a que o mestre das Arcadas também alude para explicar a proteção subjetiva do direito processual intertemporal. Voltaremos a tratar dessas lições no capítulo seguinte.

${ }^{271}$ A propósito das teorias do processo como contrato ou quase contrato, v. GRINOVER, CINTRA e DINAMARCO, Teoria geral do processo, pp. 279-280.

${ }^{272}$ Isso porque, o princípio da instrumentalidade das formas somente se justifica a partir de uma concepção pública do processo. Em um processo dominado pelo princípio dispositivo, a exigência da forma torna-se muito mais relevante e a parte poderia exigir que as conseqüências da sua não observância pela parte contrária fossem aplicadas, ainda que não houvesse prejuízo.
} 
Soma-se a esse fato que as relações diretas entre as partes no processo são poucas, sendo mais comum que esse vínculo direto se estabeleça entre partes e juiz. Conforme demonstraremos no Capítulo VII, adiante, essa menor freqüência com que as partes se interrelacionam diretamente no processo diminui sobremaneira a existência de direitos processuais adquiridos, o que relativiza a importância desse instituto para o direito processual civil intertemporal.

Assim, se na teoria geral do direito intertemporal o direito adquirido é o instituto de maior relevância ${ }^{273}$, no direito processual intertemporal ele é mais um astro que gravita nesse sistema, sem lugar em relevo. Essa importância secundária não decorre de uma força menor dos direitos adquiridos no plano processual, já que, por ter natureza constitucional, a proteção a ele é tão elevada quanto a dos direitos materiais adquiridos. O que ocorre é uma perda de destaque em virtude da freqüência menor de problemas que são diretamente solucionados a partir da observância de sua existência. A incidência da norma sobre direitos processuais adquiridos acaba sendo mais rara, porque mais reduzidos são esses direitos.

Além dessa diferença, o princípio da eficácia imediata da lei processual pode sofrer temperamentos nos casos em que a aplicação imediata da lei processual puder acarretar prejuízos para a efetividade do processo. Se em determinadas situações excepcionais o juiz perceber que a utilização da nova lei poderá implicar em prejuízos para o bom andamento da marcha procedimental, poderá ele afastar a aplicação imediata da lei nova, fenômeno que, oportunamente, será estudado de maneira mais detalhada.

\footnotetext{
${ }^{273}$ Se essa não é uma verdade para todos os sistemas de direito intertemporal, no nosso sistema ela é, em virtude da proteção contida no art. 5º, inc. XXXVI, da Constituição Federal.
} 


\section{Capítulo VI - Estágio atual do direito processual civil intertemporal}

\subsection{Objeto do estudo}

Nos capítulos precedentes procuramos traçar as linhas mestras do nosso direito intertemporal e justificar o enfoque processual da disciplina. Superada essa etapa podemos entender o estágio atual do direito processual intertemporal brasileiro.

A análise será feita mediante estudo separado da legislação, doutrina e jurisprudência sobre o tema. Iniciaremos esse estudo pela legislação para facilitar a compreensão dos demais elementos.

\subsubsection{Normas gerais de direito processual civil intertemporal}

A quase inexistência de regras processuais relativas ao direito intertemporal é uma constatação que invariavelmente vem acompanhada de crítica pela doutrina ${ }^{274}$.

A carência legislativa nesse tema se dá tanto com relação a regras gerais de direito intertemporal que se apliquem indistintamente para quaisquer novas leis processuais, como para as regras específicas de direito transitório.

\footnotetext{
${ }^{274}$ Em seus Estudos sobre o novo Código de Processo Civil, obra escrita por ocasião da entrada em vigor do CPC de 1.973, BARBOSA MOREIRA, após observar que na reforma processual ocorrida na Itália em 1.950 o legislador preocupou-se com a disciplina do direito intertemporal, dedicando dezessete artigos para disciplinar o modo pelo qual as leis reformadoras incidiriam sobre os processos pendentes e que até mesmo o legislador brasileiro do Código de 1.939 teve maior cautela no trato da matéria, asseverou que (p.35): “o novo Código é, no particular, de um laconismo verdadeiramente alarmante. Ele se limita a dispor, no art. 1.211: 'Este Código regerá o processo civil em todo o território brasileiro. Ao entrar em vigor, suas disposições aplicar-se-ão desde logo aos processos pendentes'”.
} 
Com relação às primeiras destaca-se a controvérsia a propósito da natureza do art. 1.211 do Código de Processo Civil, que dispõe: este Código regerá o processo civil em todo o território brasileiro. Ao entrar em vigor, suas disposições aplicar-se-ão desde logo aos processos pendentes.

A redação do dispositivo dá a entender que se trata de uma simples regra de direito transitório, a qual visava solucionar os conflitos de direito processual intertemporal que surgissem no momento da entrada em vigor do novo Código.

Contudo, a ausência de regras gerais sobre a matéria, somada à grande amplitude dessa norma, que se aplica generalizadamente a todo um Código de Processo, levou muitos doutrinadores a utilizarem-na como regra geral que dita a aplicabilidade imediata da lei processual para os processos pendentes $^{275}$.

Em sentido oposto, parte da doutrina enxerga nesse dispositivo apenas uma norma de direito transitório que disciplina o modo de aplicação da lei que instituiu o Código de Processo Civil aos processos pendentes quando de sua entrada em vigor. A aplicação desse artigo seria limitada à lei em que ele está inserido e não poderia ser utilizada para reger a eficácia das leis processuais supervenientes $^{276}$. A literalidade do texto em análise, que se refere expressamente à vigência daquela lei (este Código regerá... ao entrar em vigor suas disposições aplicar-se-ão) pode conduzir a essa interpretação. Além disso, a localização do dispositivo no Livro $\mathrm{V}$ do Código, que trata de suas disposições finais e transitórias, também favorece o entendimento de que se trata realmente de uma norma transitória.

\footnotetext{
${ }^{275}$ V. MOACYR AMARAL SANTOS, Primeiras linhas de direito processual civil, $1^{\circ}$ vol., pp.29-34, esp. p. 32 e JOSÉ FREDERICO MARQUES, Manual de direito processual civil, $1^{\circ}$ vol, p. 42, esp. nota 1.

${ }^{276}$ Ao comentar o conteúdo do art. 1.211 do CPC, afirma CÂNDIDO DINAMARCO, A Reforma do Código de Processo Civil, p. 42, que: "Dispositivos como esse, buscando desde logo delimitar a dimensão da própria lei que os contém, não são regras de superdireito mas limitações especificamente ditadas quanto à eficácia temporal daquele diploma. Por isso, ao assim dispor, o Código de Processo Civil em nada contribui para a determinação dos limites de eficácia das leis que o modificam. O art. 1.211 só pretendeu disciplinar a vigência do próprio Código, não a de leis futuras que incidam sobre a matéria que ele disciplina”. No mesmo sentido, v. FÁBIO PESSOA, Elementos para uma teoria..., p. 134-136.
} 
Entendemos, todavia, ser mais acertada a primeira corrente, diante da amplitude generalizada da aplicação da norma em análise. Se ela era utilizada para determinar indistintamente a eficácia de todas as regras de um novo Código de Processo Civil então instituído - à exceção dos poucos casos regrados especificamente $^{277}$ - parece-nos mais adequado interpretar o dispositivo como uma regra geral do sistema, e não limitar sua aplicação à lei em que estava contido $^{278}$.

Mas a controvérsia tem pouca relevância prática, porque a aplicabilidade imediata da lei processual aos processos pendentes, se não for extraída do art. 1.211 do CPC, decorre, então, do art. $6^{\circ}$ da LICC ${ }^{279}$.

Deve-se mencionar ainda, em matéria de regras gerais de direito processual intertemporal, a contida no art. 87 do Código de Processo $\mathrm{Civil}^{280}$ a qual estatui que determina-se a competência no momento em que a ação é proposta. São irrelevantes as modificações do estado de fato ou de direito ocorridas posteriormente, salvo quando suprimirem o órgão judiciário ou alterarem a competência em razão da matéria ou da hierarquia.

A redação do dispositivo deve ser analisada sob duplo enfoque, um relativo às alterações de fato e de direito que atinjam qualquer dos

\footnotetext{
${ }^{277}$ Como os casos previstos nos artigos 87, 1.217 e 1.218 .

${ }^{278}$ Esse também parece ser o entendimento de THEOTONIO NEGRÃO e JOSÉ ROBERTO FERREIRA GOUVÊA, que na nota $\mathrm{n}^{\circ} 1$ ao art. 1.211 do CPC fazem a seguinte observação: "No CPC ant., esta disposição constituía seu art. $1^{\circ}$, onde estava mais bem situada" (Código de Processo Civil e legislação processual em vigor, p. 1.109).

${ }^{279}$ Nesse sentido, v. HUMBERTO THEODORO JÚNIOR, Curso de direito processual civil, vol. I, pp. 1920. Para ROGÉRIO LAURIA TUCCI tal princípio seria uma decorrência do art. $2^{\circ}$ do Código de Processo Penal que dispõe que "a lei processual penal aplicar-se-á desde logo, sem prejuízo da validade dos atos realizados sob a vigência da lei anterior”, por ser essa uma regra de super direito (Enciclopédia Saraiva de Direito, vol. 46, pp. 249-259). FÁBIO PESSOA, Elementos para uma teoria..., pp. 135-136, refuta essa idéia asseverando "que se trate de regra de super direito, no sentido de dispor sobre outras regras não há dúvida, mas limitadamente ao processo penal, não bastando tal característica obviamente para autorizar a ampliação de seu alcance a outros ramos da ciência jurídica. Cabe ainda recordar que as leis processuais penais não têm aplicação subsidiária no processo civil, de modo que quanto a este, na falta de regras específicas, o norte há de ser buscado, além da própria Constituição, na Lei de Introdução ao Código Civil, instituidora de regras gerais válidas para todo o ordenamento jurídico".

${ }^{280}$ Afirma FÁBIO PESSOA, Elementos para uma teoria ..., p. 135, que: “A rigor, a única hipótese em que se pode reconhecer no Código vigente disposição com características de regra intertemporal válida para a generalidade dos casos - não obstante o limitado alcance, dada a matéria específica afetada - diz respeito ao seu art. 87". Essa afirmativa justifica-se pelo fato do autor ser contrário à corrente que defende ser o art. 1.211 do CPC uma regra geral de direito processual intertemporal.
} 
elementos da demanda que possam interferir na competência para o seu julgamento e outro que diz respeito às alterações das regras de competência para julgar a demanda.

Exemplificando o primeiro enfoque podemos pensar numa ação indenizatória movida em face de um réu que ao tempo da propositura da demanda estava domiciliado em São Paulo e posteriormente transferiu-se para o Rio de Janeiro. Considerando-se a regra geral de que as ações devem ser propostas no domicílio do réu (CPC, art. 94), seria possível indagar se sua alteração teria ou não o condão de modificar a competência para julgamento da demanda.

A resposta para essa indagação parece simples e até mesmo alheia ao direito intertemporal, porque a alteração posterior de fato não tem relação alguma com a sucessão de leis no tempo. Essa alteração, ademais, não teria o condão de alterar a competência para o julgamento da demanda, que é ditada segundo os elementos da petição inicial ${ }^{281}$.

O problema fica um pouco mais complicado se pensarmos em uma alteração de qualificação jurídica relativa a um dos elementos da demanda que possa ocasionar um desvio da competência. Para ilustrá-lo podemos imaginar que a lei (ou a Constituição) determine que as Varas do Trabalho são responsáveis para dirimir as controvérsias que versem sobre a relação empregatícia. A solução dos litígios decorrentes de relações de prestação de serviço não se inserem na esfera de competência desses juízos e, portanto, deverão ser julgadas pela justiça comum. Imagine-se, então, que sobrevenha uma lei que afirme que a prestação de serviço de empregado doméstico diarista passa a ser considerada como relação de emprego. Haverá uma sucessão de leis regendo o mesmo fato e a alteração na sua qualificação tem o condão de modificar o juízo competente para julgar as demandas envolvendo essa relação.

\footnotetext{
${ }^{281}$ O princípio da perpetuatio jurisdicionis contido no dispositivo em estudo, contudo, não se aplica para as alterações de fato relativas à competência absoluta. Nesse sentido, v. BEDAQUE, Competência e suspeição julgados e pareceres, p. 420-421.
} 
Resta a indagação, como ficam os processos pendentes no momento da entrada em vigor do segundo diploma legal?

Uma resposta mais apressada poderia conduzir ao entendimento de que, tratando-se de competência absoluta, as demandas pendentes deverão ser redistribuídas a uma das Varas Trabalhistas. Contudo, essa solução deixa de observar o problema efetivo de direito intertemporal, que não tem relação com o direito processual. O que a lei alterou foi o modo de regulamentar uma determinada relação jurídica de direito material, não a competência para o julgamento da demanda. Resulta daí que todos os conflitos surgidos na relação entre empregador doméstico e empregado diarista após o advento da nova lei deverão ser julgados pelo juízo trabalhista, enquanto que os conflitos surgidos de fatos anteriores à lei serão da competência da justiça comum, ainda que a demanda seja distribuída posteriormente à mudança da legislação. Isso porque esses últimos não eram e nem se tornaram conflitos envolvendo relação de emprego.

\section{Feitas essas considerações fica fácil compreender 0} verdadeiro conteúdo do art. 87 do Código de Processo Civil em termos de direito intertemporal. O que a norma traz de diferente da regra geral contida no art. 1.211 é a limitação da eficácia imediata das leis que tratam de competência, mantendo a aplicação do art. 1.211 apenas para as leis que disponham sobre competência absoluta ou que tratem da supressão de um órgão judiciário ${ }^{282}$.

Se a nova lei versar sobre matéria relacionada a competência relativa ela não terá eficácia imediata para os processos pendentes, que permanecerão regrados pela lei anterior. Esse talvez seja o caso mais típico de ultratividade da lei processual, porque é o único regulamentado por norma geral $^{283}$.

\footnotetext{
${ }^{282}$ Comentando o dispositivo GALENO LACERDA afirma que "em direito transitório vige o princípio de que não existe direito adquirido em matéria de competência absoluta e organização judiciária. Tratando-se de normas impostas tão-só pelo interesse público na boa distribuição da Justiça, é evidente que toda e qualquer alteração da lei, neste campo, incide sobre os processos em curso, em virtude da total indisponibilidade das partes sobre essa matéria" ( $O$ novo direito processual civil e os feitos pendentes, p. 5). ${ }^{283}$ Vale registrar que o legislador processual pátrio historicamente deixou de criar normas gerais de direito processual intertemporal. Em todos os diplomas processuais que vigeram no Brasil são bastante escassos os dispositivos gerais sobre o tema e, na maioria das vezes limitaram-se a afirmar a eficácia imediata da lei processual. FÁBIO PESSOA, Elementos para uma teoria..., p. 133, registra como exceção o Código de
} 


\subsubsection{Normas transitórias de direito processual civil intertemporal}

A indisposição do nosso legislador para tratar de direito processual intertemporal verifica-se tanto em matéria de leis gerais como de dispositivos de direito transitório. Ilustra essa indisposição a ausência de dispositivos sobre o tema nas últimas leis que reformaram o Código de Processo Civil $^{284}$.

De maneira geral, pode-se notar um pouco mais de preocupação do legislador no que se refere à disciplina recursal, dado que muitos Códigos Estaduais detinham regras de direito transitório sobre a matéria ${ }^{285}$, a qual também foi regulada pelo Código de Processo Civil de 1.939 (art. 1.047, § $2^{\circ}$ ) e no art. 1.217 do Código atual.

Contudo essa preocupação só é verificada em momentos de ruptura, em que um novo código é elaborado, porque as leis que alteram a disciplina recursal de maneira isolada não costumam deter regras transitórias de direito intertemporal ${ }^{286}$.

Exceções a esse 'abandono legislativo' podem ser notadas na Lei do Inquilinato (Lei Federal $n^{\circ} 8.245$, de 18 e outubro de 1.991) e na Lei de Falências, Lei $n^{\circ} 11.101$, de 9 de fevereiro de 2.005, cujos artigos 76 e 192,

Processo Civil do Distrito Federal, que vigeu durante o período em que os Estados detinham ampla competência para legislar sobre matéria processual. Nesse diploma, o direito intertemporal estava tratado nos artigos 1.196 a 1.199, e, além da eficácia imediata e do respeito aos atos anteriormente praticados, conferia uma disciplina mais detalhada para a forma dos atos e para os procedimentos especiais. No Anteprojeto de Lei Geral de Aplicação das Normas Jurídicas elaborado pelo Professor HAROLDO VALLADÃO a matéria estava prevista no art. 85 que, além de ditar a eficácia imediata da lei processual no tempo, trazia disposições sobre a competência, os prazos e os recursos.

${ }^{284}$ V. Leis Federais no ${ }^{\circ}$ 8.455/92; 8.637/93; 8.710/93; 8.718/93; 8.898/94; 8.950/94; 8.951/94; 8.952/94; 8.953/94; 9.079/95; 9.139/95; 9.245/95; 9.800/99; 10.352/01; 10.2358/01; 10.444/02; 11.187/05; 11.232/05; 11.276/06; 11.277/06 e 11.280/06.

285 WELLINGTON MOREIRA PIMENTEL, A aplicação do novo código de processo civil às causas pendentes, pp. 16-17, destaca que nos códigos de Minas Gerais (art. $1^{\circ}$ das disposições transitórias); Pernambuco (art. 1.503) e do Distrito Federal (art. 1.199), havia dispositivos que determinavam o respeito aos recursos interpostos anteriormente, não só quanto a sua admissibilidade como ao seu processamento.

${ }^{286}$ Como exemplos podemos citar as alterações promovidas no recurso de apelação pelas leis $n^{\circ}$ s 10.352/01 e 11.276/06, que introduziram, respectivamente, os parágrafos $3^{\circ}$ e $4^{\circ}$ ao art. 515. 
respectivamente, reservaram a eficácia das leis apenas para os processos distribuídos após as suas vigências.

O destaque negativo em termos de tratamento transitório do direito processual intertemporal foi o conferido pela Lei $\mathrm{n}^{\circ} 8.009$, de 29 de março de 1.990, que instituiu a impenhorabilidade do bem de família e determinou o cancelamento das penhoras anteriormente realizadas.

\subsection{Doutrina}

No início deste trabalho afirmamos que os estudos específicos de direito intertemporal processual são poucos na doutrina nacional. Isso não significa, todavia, que a disciplina tenha sido ignorada pelos nossos tratadistas, ou que tenha sido relegada para a teoria geral do direito.

Quase todos os manuais brasileiros de direito processual civil detêm um tópico sobre a matéria, uns de maneira mais detalhada, outros superficialmente, mas, dada a complexidade do tema são raríssimos os trabalhos que o abordam em seus principais aspectos.

Em termos gerais, grande parte da doutrina recorre à divisão feita por CHIOVENDA ${ }^{287}$ sobre os 'sistemas de direito processual intertemporal' e procura inserir o 'sistema brasileiro' em um desses modelos. Merecem destaque, pelo aprofundamento dado à matéria, os estudos de FÁBIO GUIDI TABOSA PESSOA, GALENO LACERDA e CÂNDIDO RANGEL DINAMARCO, que abordaremos de maneira mais detalhada adiante. Antes, porém, cumpre estudarmos os sistemas de direito processual intertemporal e as razões que levam à sua insuficiência para o direito brasileiro.

287 ALFREDO DE ARAÚJO LOPES DA COSTA, Direito processual civil brasileiro, vol. I, p. 254, menciona como fonte criadora da divisão dos sistemas de direito processual intertemporal o processualista SCHRUTKA. 


\subsubsection{Os 'sistemas' de direito processual intertemporal}

Ao tratar do modo como a lei nova poderia atingir os processos pendentes vislumbrou CHIOVENDA três possíveis soluções para o problema, quais sejam, (a) aplicar a lei antiga até a conclusão do processo; (b) aplicar a nova aos atos sucessivos e (c) divisão da causa em períodos, de maneira que, até o preenchimento de um período, se aplique a lei antiga, e daí por diante a nova ${ }^{288}$.

\section{MOACYR AMARAL SANTOS ${ }^{289}$ aprimorou esses} ensinamentos e dividiu os sistemas de direito processual intertemporal em três categorias, a saber:

(a) sistema da unidade processual. Considera-se que o processo é um complexo de atos inseparáveis e, por isso, todos os seus atos teriam que ser regulados por uma única lei. A diferença observada pelo Professor brasileiro da primeira hipótese vislumbrada por CHIOVENDA é que tanto se poderia aplicar a lei antiga para todo o processo, como a lei nova. Nesse último caso, ao reger os atos praticados antes de sua entrada em vigor, teria a lei nova efeito retroativo ${ }^{290}$.

(b) sistema das fases processuais. Equivale à terceira hipótese vislumbrada por CHIOVENDA, com a explicação e divisão de cada uma das fases processuais. Na concepção de MOACYR AMARAL SANTOS, tal sistema considera a existência de fases processuais autônomas, quais sejam, a postulatória, a probatória, a decisória e a dos recursos. Cada uma delas

\footnotetext{
${ }^{288}$ Instituições de direito processual civil, vol. I, p. 95.

${ }^{289}$ Primeiras linhas de direito processual civil, vol. 1, pp. 31-32.

${ }^{290}$ LOPES DA COSTA também dividira os sistemas de direito processual intertemporal seguindo essa orientação. Ao tratar das duas possibilidades do sistema da unidade processual, o autor desdobra-os em integral aplicação da lei anterior e integral aplicação da lei atual (Direito processual civil brasileiro, vol. I, pp. 254-255)
} 
compreenderia um conjunto de atos inseparáveis, constituindo, assim, uma unidade processual. Essas fases seriam sempre regradas pela mesma lei que, ao entrar em vigor, regularia somente as fases ainda não iniciadas. As já começadas, como teriam atos praticados sob a égide da lei antiga, permaneceriam por ela disciplinadas.

Ao tratar desse sistema, a doutrina costuma divergir quanto à divisão das fases processuais, especialmente antes do julgamento de primeiro grau. A principal divergência existente consiste na existência ou não de uma fase ordinatória, posterior à postulatória e anterior à instrutória ou probatória ${ }^{291}$.

(c) sistema do isolamento dos atos processuais. Considerase que apesar de ser uma unidade, em vista do fim a que se propõe, o processo é um conjunto de atos que podem ser considerados isoladamente para os efeitos da lei nova, e, por isso, permite-se que ela incida diretamente sobre os atos ainda não praticados. Deve-se respeitar, todavia, os efeitos dos já praticados, para evitar a retroatividade.

Esse sistema é fortemente influenciado pela teoria objetivista do direito intertemporal e se adéqua com maior facilidade nos países que não detenham proteção constitucional para o direito adquirido.

A divisão exposta representa apenas um modo de explicar como os diversos sistemas podem regulamentar o direito processual intertemporal. Conforme demonstraremos nos tópicos seguintes, nosso ordenamento não adotou nenhum desses sistemas e nem seria aconselhável que o fizesse.

${ }^{291}$ V. MARCELO ABELHA RODRIGUES, A terceira etapa da reforma processual civil, p. 18, CÂNDIDO DINAMARCO, Instituições de direito processual civil, vol. I., p. 100. Na divisão de LOPES DA COSTA as fases eram postulatória, de contestação, probatória, decisória e de recursos. (Direito processual civil..., vol. I, p. 257). 


\subsubsection{Ordenamento jurídico brasileiro e insuficiência dos grandes 'sistemas' de direito intertemporal}

Inicialmente cumpre observar que dos três sistema de direito intertemporal o que mais se aproxima do atual modelo brasileiro é o do isolamento dos atos processuais ${ }^{292}$.

Seria equívoco, contudo, supor que nosso sistema se encaixa perfeitamente no do isolamento. Primeiramente, porque existe um limite para a eficácia imediata da lei processual, qual seja, o respeito aos direitos adquiridos processuais ${ }^{293}$. Isso significa que nem sempre a lei processual terá eficácia imediata. Caso sua aplicação possa ferir algum direito processual adquirido, a situação jurídica processual será regida pela lei anterior de modo a preservar esse direito.

\footnotetext{
${ }^{292}$ Diferentemente do modelo adotado pelo Código de Processo Civil de 1.939 que se aproximava bastante do sistema das fases processuais, pois o $\S 1^{\circ}$ do, art. 1.047, dispunha: "As ações cuja instrução esteja iniciada em audiência serão processadas e julgadas, em primeira instância, de acordo com a lei anterior, salvo quanto às nulidades". Comentando esse dispositivo alguns autores afirmaram que o Código de 39 teria adotado o sistema das fases processuais (LOPES DA COSTA, Direito processual civil..., vol. I, p. 257; WELLINGTON MOREIRA PIMENTEL, A aplicação do novo código de processo civil aos feitos pendentes, p. 18), o que não nos parece exato, pois a regra prevista no caput do art. 1.047 era justamente a da aplicação imediata da lei aos processos pendentes. Concordamos com a opinião de FÁBIO PESSOA para quem o legislador de 39 optou por uma fórmula mais atenuada de conferir eficácia imediata à lei processual (Elementos para uma teoria..., p. 133).

${ }^{293}$ Comentando o art. 1.211 do CPC, pontua ANTÔNIO CLÁUDIO DA COSTA MACHADO: "Malgrado já se encontrarem superadas as dificuldades que esta regra desencadeou - pelo simples fato do decurso de quase duas décadas de vigência deste Código de Processo, v. art. 1.220 - parece relevante salientar que a prescrição sob enfoque não significa a pura adoção do sistema do 'isolamento dos atos processuais' (em contraposição ao sistema da 'unidade processual' e ao das 'fases processuais'), porque a aplicação imediata dos seus preceitos sempre tem que ser examinada à luz das garantias constitucionais da coisa julgada (o processo findo fica imune, evidentemente, à lei nova), do ato jurídico perfeito ( no processo de conhecimento, execução e cautelar, e do direito adquirido reconhecido pela sentença ou resultante de atos executórios(também nos processos de conhecimento, execução e cautelar) (Cintra, Grinover, Dinamarco). Melhor seria se o CPC houvesse consagrado, de forma expressa, o princípio da irretroatividade da lei processual como fez o art. $2^{\circ}$ do CPP" (Código de Processo Civil interpretado artigo por artigo, parágrafo por parágrafo, p. 1.459). Discordamos da parte final do pensamento do autor já que a alteração do dispositivo para a forma prevista no Código de Processo Penal não traria, em nosso sentir, qualquer alteração para o problema. De outra parte, limitamos a eficácia da lei processual nova ao respeito aos direitos processuais adquiridos porque, conforme demonstramos acima, somente essa garantia tem relevância para a limitação em questão já que os atos jurídicos perfeitos estão contidos dentro da garantia contra a retroatividade da lei. A coisa julgada para o direito processual intertemporal tem relação direta com os direitos adquiridos, o que ficará mais claramente explicado adiante.
} 
Além disso, em alguns casos excepcionais o juiz poderá efetuar um controle sobre a eficácia imediata da lei processual, de modo a impedir que uma determinada lei tenha eficácia sobre um processo pendente. Nessas situações haverá um natural distanciamento do modelo previsto para o isolamento dos atos processuais, em virtude da sobrevivência da lei anterior.

É evidente que, sendo raros esses casos, eles não infirmam a assertiva de que existe uma regra geral de eficácia imediata da lei processual. Parece-nos, contudo, pouco adequado inserir nosso sistema dentro de um modelo pré-concebido como é o sistema do isolamento dos atos processuais, se esse modelo não comporta exceções ${ }^{294}$.

\subsubsection{Razões teóricas para justificar o distanciamento da doutrina dos 'sistemas'}

A doutrina de CHIOVENDA, LOPES DA COSTA e MOACYR AMARAL SANTOS deve ser louvada naquilo que tem de melhor: é um meio didático de explicar aos iniciantes quais as diferentes maneiras como a lei processual pode atingir os atos processuais.

Saindo desse campo, esses ensinamentos não devem ser utilizados para explicar o sistema brasileiro de direito processual civil intertemporal. Isso porque, além de ser insuficiente para descrever o modo como nosso ordenamento regula a matéria, tais modelos são muito fechados, o que os torna pouco eficientes. De fato, além de não haver a adoção expressa de qualquer um desses sistemas, em tempos de criação de um novo Código de Processo Civil não seria o caso nem mesmo de sugerir que o legislador aderisse a algum desses modelos.

\footnotetext{
${ }^{294}$ Essa também é a opinião de LUCAS RISTER DE SOUZA LIMA, Direito intertemporal no processo civil , pp. 106-107, FABIO PESSOA, Elementos para uma teoria..., pp. 190-191 e GUILHERME RIZZO AMARAL, Estudos de direito intertemporal e processo, pp. 20-21.
} 
Se colocássemos os três sistemas em uma linha, teríamos em um extremo o da unidade processual e no outro o do isolamento dos atos processuais. No meio, sendo realmente uma mistura dos dois, ficaria o das fases processuais, que, de um lado tenta manter a unidade do regramento de alguns atos processuais e, de outro, permite que um mesmo processo seja regulado por leis diferentes.

A principal vantagem da unidade processual consiste na manutenção de uma coerência no processo, tendo em vista que todos os seus atos são coordenados para um único fim. Regrando-se todos os atos do processo por uma única lei, seria possível evitar a desconexão entre atos ou uma eventual desorientação do processo decorrente da regulamentação de atos que são coordenados na prática por leis distintas e possivelmente conflitantes entre $\mathrm{si}^{295}$.

Já a maior vantagem do sistema do isolamento dos atos processuais consiste na eficiência que se daria ao processo pendente, partindose da premissa que a lei nova tende sempre a ser mais aperfeiçoada e, portanto, mais apta a permitir que o processo alcance seus objetivos com menor consumo de recursos ${ }^{296}$.

Poder-se-ia imaginar que um sistema temperado, como $o$ das fases processuais, seria o mais adequado, dado que traria vantagens de ambos os sistemas e permitiria uma aplicação mais equilibrada das exigências que se contrapõem.

\footnotetext{
${ }^{295}$ Retomamos aqui os ensinamentos de CARNELUTTI, Sistema de direito processual civil, vol. I, p. 168, mencionados no capítulo anterior. LOPES DA COSTA, embora não fosse partidário desse sistema, assim explicou o seu fundamento: "O processo não é um conjunto de atos independentes, mas de atos estreitamente relacionados, que fortemente se subordinam a um fim: a decisão. Deve, pois, ser regido por uma só lei, ou integralmente pela lei antiga ou integralmente pela lei nova" (Direito processual civil..i, vol. I, p. 255).

${ }^{296}$ Nesse sentido, leciona ROGÉRIO LAURIA TUCCI a propósito da aplicação do princípio tempus regit actum ao processo que "competindo ao Estado disciplinar, como melhor entender, a administração da justiça, é de presumir-se seja ela (a nova lei) mais perfeita do que a precedente, quer para a proteção do interesse coletivo, quer também, nos Estados de Direito, para a tutela dos direitos individuais" (Direito intertemporal e a nova codificação processual penal, p. 5).
} 
Entendemos, todavia, que essa não é uma solução adequada, porque o sistema das fases processuais traz consigo não só virtudes dos dois outros sistemas como também seus defeitos. Pode-se dizer que ele é um sistema médio, mas não melhor.

Sistema realmente temperado, que seja capaz de utilizar de forma mais adequada as vantagens de cada um deles, será um que saiba dosar a aplicação da nova lei em função dos prejuízos que possam advir de sua eficácia imediata.

Para melhor explicar, devemos considerar que nem sempre a utilização de duas ou mais leis processuais causará alguma espécie de desconexão ou desorientação que possa ocasionar alguma espécie de prejuízo para a coerência do processo. É plenamente possível que uma nova lei tenha ligação com um determinado ato já praticado no processo e venha a regulamentálo sem causar qualquer desconexão. Basta pensar, por exemplo, nos processos pendentes antes do advento da tutela antecipada prevista no art. 273 do Código de Processo Civil.

O pedido já havia sido formulado e, muito embora a antecipação de seus efeitos não consista em qualquer alteração desse pedido, não há como negar que ela tem, em si, conexão com ele. A utilização da nova lei no processo pendente, de modo a permitir ao autor que requeira ao juiz a antecipação dos efeitos da tutela jurisdicional já pleiteada anteriormente não ocasiona, contudo, qualquer desconexão ou desorientação do processo. Em qualquer fase que esse se encontre, será vantajosa a utilização dessa técnica.

Por outro lado, nem sempre a utilização de uma nova lei será capaz de favorecer a eficiência do processo.

Imagine-se, por exemplo, que em um determinado sistema processual a competência para julgamento dos embargos à arrematação seja a do juízo da execução. Suponha-se que em um determinado processo a penhora tenha sido feita mediante a expedição de carta precatória e que os autos já 
tenham sido devolvidos, tendo sido opostos os embargos no juízo deprecante. Por fim, considere-se que, antes da decisão dos embargos sobrevenha uma lei alterando a competência para julgamento dos embargos envolvendo questões relativas à penhora ou à arrematação, transferindo-a para o juízo deprecado. O objetivo da lei será favorecer a economia processual permitindo que, se porventura os embargos forem acolhidos, uma nova penhora seja realizada junto ao juízo deprecado ${ }^{297}$. No caso específico em que a devolução dos autos tenha ocorrido e os embargos sido opostos perante o juízo deprecante, a devolução dos autos ao juízo deprecado não atingirá o escopo da lei e apenas servirá para atrasar o curso do processo, não sendo lícito afirmar que a aplicação da nova lei favorecerá a efetividade do processo.

Feitas essas colocações pode-se entender que os sistemas fechados, idealizados em um período em que o aumento de poderes do juiz era visto como um perigo à sua parcialidade, não são aptos a fornecer uma disciplina adequada para a matéria. Melhor será, então, que o sistema seja dotado de regras e princípios gerais para orientar o julgador, mas que também detenha mecanismos para afastar umas e mitigar outros quando for necessário, para se conferir melhor efetividade ao instrumento processo.

\subsubsection{O posicionamento de GALENO LACERDA: um caminho a ser trilhado}

Pouco tempo depois da entrada em vigor do Código de Processo Civil de 1.973 GALENO LACERDA publicou o trabalho $O$ novo direito processual civil e os feitos pendentes.

\footnotetext{
${ }^{297}$ O exemplo foi extraído da hipótese observada por GALENO LACERDA, O novo direito processual civil e os feitos pendentes, pp. 8-9, ao comentar a inovação trazida no art. 747 do Código de Processo Civil de 1.973, que conferia competência ao juízo deprecado para conhecer e julgar os embargos do devedor (posteriormente, a lei 8.953/94 reduziu essa competência, limitando-a ao julgamento dos embargos que versassem exclusivamente sobre vícios ou defeitos da penhora, avaliação ou alienação de bens). A solução por ele apresentada, contudo, não adentra a problemática da maior ou menor eficiência da nova lei, mencionando apenas a regra do art. 87 do CPC, a qual afirma que a competência se determina no momento da propositura da demanda. Assim, como os embargos já teriam sido opostos, entendeu ele que a competência já estaria determinada. Contudo, como a competência em questão é determinada por uma questão funcional e não territorial, a utilização da regra contida no art. 87 não teria o condão de afastar a aplicabilidade imediata da lei nova.
} 
A obra do Professor gaúcho contém breves explicações preliminares sobre as regras de direito transitório ${ }^{298}$ (pp. 1 a 3), sendo seguida pela análise particularizada dos problemas atinentes à competência; acréscimo de atos; eliminação de atos; modificação de institutos processuais; recursos; prazos dilatados e prazos diminuídos.

Seu pensamento pode ser resumido na afirmação de que para o processo aplicam-se as regras gerais de direito intertemporal. Assim, a lei processual deve ter eficácia imediata, o que, em termos processuais, impõe a compreensão da doutrina de ROUBIER sobre os fatos jurídicos complexos, dado que o processo compreende uma seqüência complexa de atos que se projetam no tempo, preordenados para um fim $^{299}$.

Por outro lado, não se pode deixar de considerar a existência de direitos adquiridos processuais, os quais seriam um fator limitador da eficácia imediata da lei nova. Ao conceituá-los, o autor afirmou serem eles "oriundos dos próprios atos ou fatos jurídicos processuais, que emergem, em cada processo, do dinamismo desse relacionamento jurídico complexo"300. Em seguida, disse que o Código de Processo Civil é expresso em admiti-los no seu art. 158 e asseverou que "existem direitos adquiridos à defesa, à prova, ao recurso, como existem direitos adquiridos ao estado à posse, ao domínio",301.

Por fim, ressalvou que "acontece que os direitos subjetivos processuais se configuram no âmbito do direito público e, por isto, sofrem o condicionamento resultante do grau de indisponibilidade dos valores sobre os quais incidem" ${ }^{302}$.

\footnotetext{
${ }^{298}$ Que na verdade são as explicações dos princípios gerais da disciplina do direito processual intertemporal, já que, como visto, nosso Código foi muito econômico no que diz respeito à formulação de normas de direito transitório.

${ }^{299}$ O novo direito processual..., p. 2. Após fazer essa observação GALENO LACERDA recobra as lições de ROUBIER sobre o respeito aos efeitos dos atos anteriores à entrada em vigor da lei nova, bem como aos seus momentos de constituição e extinção, para evitar o fenômeno da retroatividade.

${ }^{300} \mathrm{O}$ novo direito processual..., p. 3.

${ }^{301} \mathrm{O}$ novo direito processual..., p. 3.

${ }^{302}$ O novo direito processual..., p. 3.
} 
Em que pese serem sucintos, esses ensinamentos foram acolhidos pela grande maioria da doutrina ${ }^{303}$ o que, em certa medida, é altamente positivo e, em outra, inspira alguma preocupação.

A parte positiva diz respeito à orientação contida nesses ensinamentos. Exceção feita à ressalva final sobre a natureza dos direitos subjetivos processuais e o seu condicionamento em função do grau de indisponibilidade dos valores sobre os quais incidem, com a qual não concordamos, a afirmação da eficácia imediata da lei processual com o resguardo aos direitos processuais adquiridos é, sem dúvida, a principal orientação a ser seguida em termos de direito processual intertemporal (embora não seja a única).

De negativo, nota-se que poucos são os autores que se preocuparam em se aprofundar no conceito de direitos processuais adquiridos, o que ocasiona, muitas vezes, a simples repetição das palavras do mestre gaúcho, sem o devido cuidado que o tema merece. Isso porque, se não entendermos o que significa dizer que a lei deve respeitar os direitos adquiridos processuais, essa limitação poderá ser demasiadamente ampla ou estreita e cada um a utilizará para justificar a solução que quiser apresentar sobre o comportamento intertemporal de uma lei. Será possível diante de qualquer alteração processual legislativa dizer simplesmente, aqui não há direito processual adquirido ou, ao contrário, afirmar sua existência, para, então, afastar ou não a eficácia imediata da lei para o caso concreto.

Dentre os autores que se dedicaram a desenvolver o conceito de direito processual adquirido destaca-se CÂNDIDO RANGEL DINAMARCO.

\footnotetext{
${ }^{303}$ Veja-se assim, DINAMARCO, Instituições ..., vol. I, pp. 97-98 e A reforma da Reforma, pp. 50-51, JOSÉ OLYMPIO DE CASTRO FILHO, Comentários ao código de processo civil, vol. X, pp. 327-336, PONTES DE MIRANDA, Comentários ao Código de Processo Civil, tomo XVII, p. 14, MARCELO ABELHA RODRIGUES, A terceira etapa da reforma processual civil, pp. 1-25, HUMERTO THEODORO JÚNIOR, Curso de direito processual civil, vol. I, pp. 19-20, ERNANE FIDÉLIS DOS SANTOS, Manual de direito processual civil, vol. I, p. 4, TERESA ARRUDA ALVIM WAMBIER, "Anotações sobre o direito intertemporal e as mais recentes alterações do CPC”, pp. 262 e ss., esp. pp. 262-263, GEOVANY JEVAUX, "Direito adquirido processual", pp. 91-102, GUILHERME RIZZO AMARAL, Estudos de direito intertemporal e processo, pp. 16-18 e JOÃO BATISTA LOPES, Curso de Direito Processual Civil, vol. I, p. 17.
} 
Das lições do Professor da Faculdade de Direito da Universidade de São Paulo depreende-se que os direitos processuais adquiridos verificam-se tanto no plano das situações puramente processuais, como na dos institutos de natureza bifronte, que são institutos de direito processual material.

Com relação aos primeiros, conforme observado no Capítulo anterior, sua admissão é feita com certa reserva, acompanhada da explicação de que os direitos processuais adquiridos, decorrentes de situações jurídicas consolidadas, devem ser entendidos no amplíssimo sentido tradicional de situações jurídicas consumadas. ${ }^{304}$ A ressalva constante da explicação parece deixar claro que tais situações não devem compor o núcleo do conceito de direitos adquiridos processuais entendidos a partir de uma concepção subjetivista do direito intertemporal.

Ainda na órbita das situações tipicamente processuais capazes de gerar direitos adquiridos o mestre adere ao pensamento de GALENO LACERDA sobre o conteúdo da norma contida no art. 158 do Código de Processo Civil, asseverando que ela "não exaure as possibilidades de constituição de situações processuais intangíveis, dado que também dos atos do juiz decorrem tais situações"305.

Ao tratar dos institutos de natureza bifronte, DINAMARCO inicia suas lições alertando que não se deve exagerar as conseqüências da autonomia da relação processual, da ação e do próprio direito processual como um todo, eis que existem muitos institutos de direito processual que aproximam os planos do direito material e processual. Esses são chamados institutos bifrontes e se situam nas faixas de estrangulamento entre os dois planos do ordenamento jurídico e compõem o chamado direito processual material ${ }^{306}$.

\footnotetext{
${ }^{304}$ Como exemplo o Professor das Arcadas cita a situação consumada de réu revel e a sentença publicada, que gerariam, respectivamente, os direitos à presunção de veracidade dos fatos para o autor e de interposição do recurso para a parte sucumbente (Instituições..., vol. I, p. 99). Na obra a reforma da Reforma é trazido outro exemplo relativo a prazo diminuído por lei nova, que não pode afetar as situações constituídas anteriormente (p. 51).

${ }^{305}$ A reforma da Reforma, p. 52.

${ }^{306}$ Instituições..., vol. I, pp. 100-101.
} 
Fixadas essas premissas parte para a conclusão de que a lei processual nova deve respeitar a efetividade das situações criadas por essas normas bifrontes, associando-as à idéia de direitos adquiridos, havendo ou não um processo pendente ${ }^{307}$.

Segundo entendemos, as lições de DINAMARCO trazem novas luzes para a compreensão dos direitos processuais adquiridos, especialmente na sua associação aos institutos bifrontes e na visualização dos dois tipos de situações que podem gerar direitos processuais adquiridos, as tipicamente processuais e as processuais materiais.

\subsubsection{Análise da doutrina de FÁBIO GUIDI TABOSA PESSOA}

Em linhas gerais o sistema de direito intertemporal brasileiro esboçado pelo processualista paulista funciona da seguinte maneira: a lei processual tem eficácia imediata, devendo respeitar os direitos adquiridos processuais. Esses, contudo, nem sempre deverão ser observados, dependendo da natureza da lei superveniente ${ }^{308}$. Em determinados casos a eficácia imediata

\footnotetext{
307 Nas palavras do Professor, Instituições..., vol. I, p. 101: "Seria ilegítimo transgredir situações préprocessuais ou mesmo extraprocessuais como essas aqui consideradas, as quais configuram verdadeiros direitos adquiridos e, como tais, estão imunizadas à eficácia da lei nova por força da garantia constitucional da irretroatividade das leis (Const., art. $5^{\circ}$, inc. XXXVI)".

${ }^{308} \mathrm{O}$ esboço do 'sistema' não foi feito dessa maneira pelo autor, que ao tratar do modelo brasileiro de direito processual intertemporal apenas cuidou de demonstrar que nosso sistema não se encaixa completamente no do isolamento dos atos processuais, em virtude da necessidade de se respeitar o direito adquirido, o ato jurídico perfeito e a coisa julgada. Nessa mesma passagem o autor sugere que o sistema das 'fases processuais’ não é incompatível com o nosso sistema e pode ser utilizado, devendo-se “apenas adequar sua aplicação a especificidades próprias das normas processuais e bem assim das situações processuais passíveis de afetação" (Elementos para uma teoria..., pp. 191-192). Os elementos para traçar esse esboço foram colhidos ao longo da tese do autor, especialmente do Capítulo 9, em que são abordadas as dificuldades e os obstáculos a serem superados para a solução dos problemas de direito processual intertemporal. Com relação à possibilidade de uma determinada lei vir a ferir direitos adquiridos processuais, além do quanto já foi dito acima sobre a maior imperatividade das leis de ordem pública ou de direito público na sua concepção, destaca-se a seguinte passagem do seu trabalho (p. 173): “A (tentativa de) resposta a todas essas questões, como foi dito, demanda a análise, basicamente, de dois fatores, a natureza da lei superveniente (em relação à matéria disciplinada e mais particularmente ao seu grau de imperatividade no caso concreto) e por outro lado a natureza e características da relação ou situação no tocante às quais irá se dar a aplicação da nova norma (...). Por força desses fatores se poderá por exemplo chegar à conclusão em torno da efetiva existência ou não de um direito adquirido (ou de quais os elementos necessários à formação de
} 
da lei processual deve sofrer atenuações e ceder lugar à sobrevivência da lei antiga, com o que seria adotado o sistema de 'fases processuais'.

Deve-se mencionar que o autor não afirma categoricamente que ao afastar a aplicabilidade da nova lei ter-se-ia que adotar o sistema das 'fases processuais', mas deixa a entendê-lo ao afirmar, com relação a esse sistema, que "saliente-se por outro lado, sem embargo da falta de clareza na definição das diversas fases, que o sistema que as toma por base não deixa de ter utilidade e até mesmo relevância na solução de diversas questões previsíveis em matéria de aplicação da lei processual nova, parecendo mesmo ser inevitável que atue de certa forma como um critério temperador da aplicação imediata da lei nova a todo e qualquer ato processual futuro"309.

Entendendo-se ou não que as limitações da eficácia imediata da lei processual acarretam a necessidade de aplicação dos 'sistemas de fases processuais', é relevante destacar que essa possibilidade seria decorrente (i) da atuação dos princípios processuais; ou (ii) de freios determinados pelo encadeamento lógico das subseqüentes situações jurídicas ${ }^{310}$.

Com relação aos princípios, a justificativa apresentada foi a de que "estruturados de forma a controlar o exercício do poder e ao mesmo tempo possibilitar a participação eficiente das partes no desdobramento do processo, apresentam esses princípios a peculiar condição de se aplicarem ao processo como um todo, regendo desde o início seus atos e condicionando não só a aplicação que se faça da lei processual vigente como também a eventual incidência de leis novas"311. Em seguida, após lembrar dos princípios do devido processo legal e do juiz natural, o autor afirma que "os dois que sem dúvida mais de perto podem sentir as inflexões das alterações legislativas são os princípios do contraditório e da igualdade". ${ }^{312}$

\footnotetext{
determinada situação jurídica), bem como, num momento seguinte, acerca da revogabilidade desse direito (ou mutabilidade da situação jurídica)”.

${ }^{309}$ Elementos para uma teoria..., p. 190.

${ }^{310}$ Elementos para uma teoria..., p. 190.

${ }^{311}$ Elementos para uma teoria..., p. 184.

${ }^{312}$ Elementos para uma teoria..., p. 185.
} 
Para exemplificar seu raciocínio o autor traz dois exemplos. O primeiro em que dois réus foram citados em litisconsórcio e um deles apresentou a contestação antes do término do prazo. No interregno entre o protocolo da contestação e o término do prazo sobrevém lei autorizando a reconvenção. Na sua concepção o primeiro réu não poderia mais apresentar contestação em virtude da ocorrência de preclusão consumativa, mas a necessidade de se conferir tratamento isonômico entre as partes justificaria a aplicação da nova lei para os dois réus, o que, na realidade não corresponderia a afastar a regra da eficácia imediata da lei nova, mas a conferir-lhe efeito retroativo (para atingir uma situação já consumada). O segundo exemplo é parecido com esse e diz respeito à criação de recurso adesivo, em um processo em que a sentença tivesse sido parcialmente procedente e só uma das partes já tivesse recorrido. Nesse caso dever-se-ia conferir aplicação retroativa à lei para permitir ao primeiro autor que também apresentasse recurso adesivo.

\section{Concordamos em parte com as premissas adotadas pelo} autor, de que os princípios processuais podem influenciar na eficácia temporal da lei processual, embora discordemos radicalmente dos exemplos citados.

Entendemos que não existe no nosso sistema a figura da preclusão consumativa $^{313}$, ao menos para as partes ${ }^{314}$, o que nos conduz à

\footnotetext{
${ }^{313}$ HEITOR VITOR MENDONÇA SICA, Preclusão processual civil, pp. 152-153 é bastante incisivo ao demonstrar que: "Assim também porque essa terceira modalidade de preclusão não se enquadra nas finalidades das demais é que encontramos elementos suficientes para negar a existência de tal conceito e, por tudo isso, parece-nos que a doutrina e a jurisprudência que defendem a tal preclusão consumativa, aqui, apegaram-se a um verdadeiro dogma, como não raro ocorre, mas que não tem a menor razão de ser". No mesmo sentido caminha a orientação de BEDAQUE, Efetividade do processo e técnica processual..., pp. 143-146. Muito embora o Professor das Arcadas não chegue a negar expressamente a existência de preclusões consumativas, seu entendimento é o de que elas devem ser expressamente previstas com disposição clara impedindo a correção do ato (p. 146). Deve-se frisar, ainda, a existência de passagem específica dessa obra em que resta refutada a existência de preclusão no exemplo em análise (contestação oferecida antes do término do prazo e possibilidade de apresentar reconvenção), com respaldo em entendimento jurisprudencial vitorioso (pp. 149-152).

${ }^{314}$ A doutrina é praticamente unânime em afirmar que a preclusão que atinge os poderes do juiz é consumativa. Nesse sentido, v. MARINONI e ARENHART, Manual do processo de conhecimento, p. 656; DANIEL AMORIM ASSUMPÇÃO NEVES, Preclusão pro judicato e preclusão judicial no processo civil brasileiro, p. 26-27 e MANOEL CAETANO FERREIRA FILHO, A preclusão no direito processual civil, p. 25. De nossa parte já tivemos oportunidade de discordar desses entendimentos, ao entendimento de que o fenômeno que atinge a perda dos poderes do juiz é a preclusão lógica o que leva à conclusão de que a modalidade de preclusão dita consumativa não existe, nem para as partes nem para o juiz.. Para maiores detalhes sobre o entendimento apresentado, v. Preclusão e a instrumentalidade do processo, pp. 50-70, esp. pp. 62-70.
} 
conclusão de que em ambos os exemplos acima descritos a incidência da nova lei foi normal (aplicação imediata) e não retroativa.

De outra parte, não vemos motivos para fazer qualquer limitação quanto ao sistema a ser utilizado, caso seja afastada a eficácia imediata da lei nova. Assim, esse afastamento não deve implicar na utilização do "sistema de fases processuais", porque isso acarretaria em alguns casos o afastamento da eficácia de mais de um dispositivo da lei, ou sua inaplicabilidade para além dos limites desejados. Conforme teremos oportunidade de expor no capítulo VIII, esse controle de eficácia da lei não deve ser utilizado de maneira 'engessada' pelo juiz.

Ainda com relação a esse tema, parece-nos que a solução apresentada ficou incompleta, faltando maiores explicações sobre a forma como se dá o controle de eficácia da lei processual (se precisa ser requerida ou pode ser reconhecida de ofício), quais os limites para essa atuação (sempre que o juiz entender que haja algum prejuízo para os princípios do processo pode ele deixar de aplicar a lei nova?), bem como quais os mecanismos de controle para que essa solução possa ser bem aplicada no processo ${ }^{315}$.

Idêntico problema se verifica na delimitação dos direitos adquiridos processuais que estão assim explicados no trabalho em análise: "Uma vez que as partes, dentro do processo, desfrutam de posições subjetivas, possuindo, conforme o ponto de vista, poderes e faculdades diversos, correspondem esses a direitos adquiridos, e não podem ser desconsiderados por eventual lei superveniente, desde que processualmente 'já incorporados' ao patrimônio do sujeito processual"316.

A explicação deixada é um tanto vaga, e passa a idéia de que todos poderes ou faculdades processuais das partes podem ser passíveis de

\footnotetext{
${ }^{315}$ Em que pese nossas divergências e o entendimento de que existem espaços em aberto no sistema proposto, não podemos deixar de louvar o desbravamento de um caminho até hoje pouco explorado que diz respeito aos poderes do juiz para controlar a eficácia da lei processual.

${ }^{316}$ Elementos para uma teoria..., p. 182. Logo após fazer essa afirmação o autor constata a dificuldade de identificar o ingresso de um direito na esfera jurídica pessoal das partes, o que é agravado no plano processual, e se utiliza das explicações de GALENO LACERDA sobre o alcance dos direitos processuais adquiridos (pp. 182-183).
} 
gerar direitos processuais adquiridos, o que daria uma amplitude demasiadamente larga ao instituto e prejudicaria a efetividade do processo. $\mathrm{O}$ conceito de patrimônio processual é certamente pouco claro e bastante controverso, e deveria ter sido utilizado com ressalvas quanto à forma de entendê-lo e ao seu conteúdo.

Por outro lado, não se verifica dessa explicação quando um direito poderia ser considerado como adquirido, de modo a fazer parte do patrimônio do sujeito processual.

\subsection{Jurisprudência}

Considerando-se a complexidade do tema e sua pouca exploração pela doutrina, seria querer demais que a jurisprudência tratasse a matéria de maneira uniforme.

Essa uniformidade, de fato não existe. Mas chega a ser verdadeiramente alarmante a completa ausência de parâmetros minimamente seguros fornecidos pelas nossas mais variadas cortes em termos de direito processual intertemporal.

Com relação à existência ou não de direitos processuais adquiridos, existem muitos julgados que a reconhecem, proferidos até mesmo pelo Supremo Tribunal Federal e pelo Superior Tribunal de Justiça, mas uma leitura completa desses acórdãos demonstra que falta unidade na delimitação desse instituto, sendo muito difícil traçar seus contornos a partir dos parâmetros estabelecidos nesses julgados $^{317}$. Além disso, deve-se mencionar que também

\footnotetext{
${ }^{317}$ Como é o caso dos RE 450.504 - AgR/MG; $1^{\text {a }}$ Turma, rel. Min. CARLOS BRITTO, j. 21.11.06 (fonte www.stf.jus.br, último acesso em 16.12.09 às 17:40h); RE - 82.902, rel. Min. Cunha Peixoto (colacionado por SÁlVIO FIGUEIREDO TEIXEIRA, Código de Processo Civil Anotado, p. 767), e dos REsp's 933.553/MS e 642.838/SP, ambos da relatoria do Ministro TEORI ZAVASCKI (fonte www.stj.jus.br, último acesso em 21.12.09 às 13:00h), no antigo Tribunal Federal de Recursos também era possível encontrar esse posicionamento (v. A.C. 32.228, rel. Min. DÉCIO MIRANDA, colacionado por HUMBERTO THEODORO JÚNIOR, Lições de direito processual civil, p. 189).
} 
existem posicionamentos em sentido diametralmente oposto, negando expressamente essa existência ${ }^{318}$.

Quanto à eficácia imediata da lei processual, embora seja consenso que ela deva ocorrer, a jurisprudência não fornece bases para entender o fenômeno. A falta de compreensão sobre o significado de situação jurídica processual faz com que muitas vezes, partindo-se da mesma premissa (eficácia imediata da lei processual), se chegue a soluções distintas para casos idênticos.

Exemplo característico desse problema foi o modo como a questão da multa prevista no art. 475-J do Código de Processo Civil, instituída pela Lei 11.232 de 22 de dezembro, de 2.005 , de 2.005 foi solucionada pela jurisprudência.

É possível encontrar julgados admitindo sua aplicação imediata aos processos de execução pendentes (iniciados antes do advento da lei) ${ }^{319}$, bem como negando expressamente essa possibilidade, sendo que, em ambos, resta afirmada a eficácia imediata da lei processual ${ }^{320}$.

Para finalizar a ilustração do modo confuso e pouco (ou nada) sistematizado como o tema é solucionado pela jurisprudência, é possível encontrar acórdãos em que a eficácia imediata da lei processual é afastada, mesmo não havendo direitos processuais adquiridos a se proteger, sem que haja uma explicação mais aprofundada dos motivos que permitiram esse afastamento $^{321}$.

\footnotetext{
${ }^{318}$ REsp 1.076.080/PR; $3^{\text {a }}$ Turma; rel. Min. NANCY ANDRIGHI, j. 17.2.09; DJe 6.3.09, fonte: www.stj.jus.br, último acesso em 10.01.10 às 16:53h e AI 328.598-8/00; $2^{\circ}$ TACSP; $3^{\text {a }}$ Câmara; rel. OSWALDO BREVIGLIERI, j. 10.09.91 (colacionado por FÁBIO TABOSA PESSOA, Elementos para uma teoria..., p. 183).

${ }^{319}$ STJ; MC 14.258; $3^{\text {a }}$ Turma; rel. Min. NANCY ANDRIGHI; j. 24.11.08, fonte: www.sti.jus.br, último acesso em 10.01.10, às 16:57h.

${ }^{320}$ STJ; $3^{\text {a }}$ Turma; REsp. 962.362; rel. Min. GOMES DE BARROS; J. 6.3.08; DJU 24.3.08 (jurisprudência colacionada por NEGRÃO-GOUVÊA-BONDIOLI, Código de processo civil e legislação processual em vigor, nota 1a ao art. 475-I, p. 604).

${ }^{321}$ Exemplos extraídos da jurisprudência do STF verificam-se nos julgamentos dos Conflitos de Competência 7.505 (rel. Min. ELLEN GRACIE); 7.430 (rel. Min. CÁRMEN LÚCIA); 7.441 (rel. Min. GILMAR MENDES) e 7.221 (rel. Min. MARCO AURÉLIO), todos eles afirmando que a alteração de competência absoluta (de Justiça) não deve ter aplicação aos processos pendentes em que já tenha havido sentença. A explicação que se dá parte da unidade do processo e da coordenação de seus atos, mas não aborda o ponto
} 


\subsection{As lacunas da doutrina do direito processual civil intertemporal}

Do resumo dos principais ensinamentos sobre o tema, e da análise como ele vem tratado na legislação e na jurisprudência parece-nos lícito concluir que, de modo geral, existe uma aceitação de que a lei processual deve ter eficácia imediata, respeitando-se os direitos processais adquiridos.

Não há, todavia, contornos muito claros do que venha a ser esses direitos processuais adquiridos e, nem mesmo o conceito de situação jurídica processual é de fácil compreensão, especialmente se pensarmos que esse conceito pode se referir a todo o processo (GOLDSCHMIDT), a uma fase processual ou até mesmo à conseqüência da ausência de prática de um ato processual (revelia)

Caminhando para além do consenso, podemos ver na doutrina de FÁBIO TABOSA PESSOA a possibilidade de afastamento da regra geral de eficácia imediata da lei processual em função do equilíbrio entre essas e os demais princípios processuais. A idéia inicial foi colocada, mas ainda existem ajustes para fazê-la funcionar de maneira adequada, especialmente com relação à forma como se dá o controle de eficácia da lei processual, aos limites para essa atuação e aos mecanismos de controle para que essa solução possa ser bem aplicada no processo.

Assim, antes de concluirmos nossa tentativa de sistematização do direito processual intertemporal civil, passaremos ao estudo de cada um desses pontos na busca de diminuir as lacunas existentes, que tanto dificultam a solução dos problemas afetos à matéria.

central da questão para o direito intertemporal, que é a possibilidade (e os limites) que o juiz tem para, em determinados casos, afastar a eficácia imediata da lei. Voltaremos ao tema no Capítulo VIII. 


\section{Capítulo VII - Direitos processuais adquiridos}

\subsection{Roteiro para a delimitação dos direitos processuais adquiridos}

Conforme demonstrado anteriormente grande parte da doutrina e até mesmo a jurisprudência de nossas mais altas cortes costuma afirmar a existência de direitos processuais adquiridos, sem, contudo, explicá-los.

Compreende-se a relutância em trilhar o caminho dessa explicação, em virtude da aridez dos terrenos que a formam. De início deve-se enfrentar o complexo tema dos direitos subjetivos processuais. A dúvida sobre a natureza da ação e a possibilidade de configurá-la como um direito suscita discussões infindáveis na doutrina, havendo quem afirme a inexistência de direitos de natureza processual classificando a ação apenas como um poder.

O primeiro passo na busca da configuração dos direitos processuais adquiridos será saber se existem ou não direitos processuais subjetivos. Juntamente com esse problema está a questão de saber se, independentemente da possibilidade ou não de configuração desses direitos, é possível falar em direitos processuais adquiridos ${ }^{322}$.

Segue-se, então, a necessidade de delimitação do alcance dos direitos processuais adquiridos, a fim de explicar quais direitos (ou poderes) das partes são passíveis de aquisição e quais não. A distinção é importante para

\footnotetext{
${ }^{322}$ De fato a terminologia utilizada pela doutrina subjetivista pode leva a se pensar que somente os direitos subjetivos são objeto da proteção do direito intertemporal, já que essa é dirigida para os direitos adquiridos. Isso decorre da época em que as idéias surgiram. O termo jus quaesitum foi cunhado pelos glosadores do direito intermédio. A noção de direito adquirido nos moldes como é entendida hoje advém desse termo e foi desenvolvida principalmente pela doutrina clássica do século XIX. Nessa época os estudos sobre a relação jurídica e as distinções entre direitos, poderes e faculdades ainda não se encontravam no grau de desenvolvimento que atingiram hoje. Justamente por isso é possível encontrar exemplos de direitos adquiridos na doutrina de GABBA que, hoje, se configuram mais propriamente como faculdades protegidas pela lei do que como direitos subjetivos, já que não se dirigem para terceiros e a eles não correspondem quaisquer deveres. Exemplo do que estamos nos referindo é a maioridade, que é entendida por GABBA como um direito passível de aquisição, mas não gera para qualquer outra pessoa nenhum dever.
} 
demonstrar até onde vai a proteção de ordem subjetiva do direito processual intertemporal e onde se inicia a proteção de ordem objetiva ${ }^{323}$.

Finalmente, tem-se a questão de saber quando um determinado direito processual pode ser considerado adquirido, a fim de distinguilo das meras expectativas.

O tema, como se vê, é bastante amplo e relaciona-se com outros não menos extensos e complexos. Sem pretender esgotá-lo, já que para tanto seria necessário um trabalho exclusivamente dedicado aos direitos processuais adquiridos, buscaremos trazer elementos para auxiliar na sua melhor compreensão e delimitação.

Para alcançar nossos objetivos analisaremos em separado os direitos tipicamente processuais - subdividindo-os entre direitos decorrentes das relações entre as partes e o juiz e os advindos de relações diretas das partes -, e direitos provenientes dos institutos bifrontes.

\subsection{Direitos subjetivos ou poderes das partes}

A primeira, e talvez a principal, questão que envolve a delimitação dos direitos processuais adquiridos consiste em saber como podem ser entendidos os direitos processuais subjetivos.

Alguns processualistas entendem ser impróprio falar em direitos e obrigações de natureza processual. Essa corrente se fundamenta

\footnotetext{
${ }^{323}$ Quando tratamos de proteção de ordem subjetiva estamos nos referindo a proteção aos direitos adquiridos. A proteção de ordem objetiva é contra a retroatividade da lei. A distinção tem duas conseqüências práticas extremamente relevantes. Primeiramente, devemos recordar que a proteção ao direito adquirido é de ordem constitucional e não pode ser atingida por lei posterior. Já a dirigida contra a retroatividade da lei é prevista em lei ordinária e passível de afetação por lei ordinária. Por outro lado, quando verificarmos os poderes que o juiz detém para controlar a eficácia das normas processuais, veremos que um limite que ele não pode transpor é o do respeito aos direitos processuais adquiridos.
} 
especialmente nos ensinamentos de FAZZALARI ${ }^{324}$, que buscou superar os grandes obstáculos contidos nas doutrinas até então apresentadas para conceituar os direitos subjetivos ${ }^{325}$.

Ensinou o Professor italiano que os direitos subjetivos não podem ser entendidos a partir da análise isolada das posições jurídicas simples, que são as faculdades, os poderes e os deveres. A compreensão dos direitos subjetivos deve ser vista dentro de uma relação jurídica em que, para cada posição subjetiva ativa do titular de um direito (poderes e faculdades) corresponda uma posição subjetiva passiva daquele que será o responsável pelo seu adimplemento (dever) ${ }^{326}$, sendo certo, ainda, que não se pode prescindir do objeto com o qual esse direito se relaciona para compreender o seu significado. Esse objeto, chamado de bem em acepção bastante ampla, poderá ser material ou imaterial ou até mesmo uma situação jurídica, como o poder de transferir um bem que envolve o direito de propriedade ${ }^{327}$.

Após desenvolver essas explicações, FAZZALARI definiu os direitos subjetivos como a posição de superioridade (individualizada pela norma positiva e que o intérprete dela extrai) em respeito a um bem (na acepção técnica de objeto do comportamento valorado); posição concebida levando-se em consideração a faculdade do titular e/ou os deveres de outrem ${ }^{328}$.

\footnotetext{
${ }^{324}$ Note in tema di diritto e processo, esp. pp. 55-107.

${ }^{325}$ Para amplo resumo dessas correntes de pensamento v. Note in tema..., pp. 9 e ss.. Dentre as principais doutrinas modernas acerca do significado de direitos subjetivos destacam-se as apresentadas por WINDSCHEID (teoria da vontade) e JHERING (teoria do interesse). Conforme explica JOSÉ CARLOS MOREIRA ALVES, na construção de WINDSCHEID o direito subjetivo deveria ser entendido como "um poder da vontade, um poder de agir, que a ordem jurídica conferia a alguém, e que se dirigia contra determinada pessoa ou pelo menos contra pessoa determinável”. A concepção foi erigida a partir de uma ideologia extremamente individualista e deixava de lado um campo muito vasto de direitos totalmente desvinculados do poder da vontade, como os direitos decorrentes do nascimento, ou os pertencentes aos incapazes. Em oposição a esse pensamento JHERING definiu o direito subjetivo como "o interesse juridicamente protegido" e foi amplamente criticado por ter eleito dois elementos de naturezas distintas para o seu conceito, um de ordem material (interesse) e outro formal (tutela). Seus críticos afirmavam que para a idéia de direitos subjetivos o único elemento fundamental é a tutela estatal ("Direito subjetivo, pretensão e ação, pp. 110-111"). ENRIQUE VESCOVI, soma às críticas dirigidas a essas duas doutrinas a existência de direitos subjetivos que são conferidos a seu titular mesmo contra a sua vontade, como são os direitos irrenunciáveis, e que não se encaixariam em qualquer dessas construções (Introduccion al derecho, pp. 5455).

${ }^{326}$ Note in tema..., pp. 55-68.

${ }^{327}$ Note in tema..., pp. 82-84.

${ }^{328}$ Note in tema..., pp. 86-87.
} 
A partir desses ensinamentos alguns doutrinadores afirmam que é impróprio falar em direitos de natureza processual. O fundamento para essa assertiva é o de que os direitos subjetivos são uma situação de vantagem em relação a um bem. Diante dessa constatação, a titularidade de um direito deve ser entendida a partir da promessa de tutela da ordem jurídica em relação a esse bem, ou da legítima expectativa de obtê-la. Portanto, sendo certo que ao conferir a tutela jurisdicional o Estado não se despoja de bens nem tem seu patrimônio diminuído, não seria correto falar em direitos subjetivos de natureza processual ${ }^{329}$. O direito de ação não seria um verdadeiro direito subjetivo exercido pelo autor contra o Estado, mas um poder ou um direito de iniciativa e impulso ${ }^{330}$.

Em oposição a essa corrente existem doutrinadores que enxergam no poder do cidadão de exigir uma resposta do Estado para a sua pretensão um verdadeiro direito subjetivo ${ }^{331}$.

A solução para o problema dependerá do modo como se conceitue os direitos subjetivos.

De fato, se utilizarmos o conceito fornecido MOREIRA ALVES, talvez fique mais fácil compreender a ação como um verdadeiro direito subjetivo processual. O Ministro aposentado do Supremo Tribunal Federal, fazendo pequeno acréscimo na concepção de SILVIO PEROZZE, definiu o direito

\footnotetext{
${ }^{329}$ DINAMARCO, Instituições..., vol. II, p. 210 e Execução civil, pp. 126-129.

330 DINAMARCO, anotações ao Manual de direito processual Civil de LIEBMAN (vol. I, p. 153, nota 103). Nessa nota o processualista paulista busca explicar a afirmação feita por LIEBMAN que tratava a ação como um direito. Afirmou o mestre italiano (p. 152): "O direito de ação adquire, com isso, uma fisionomia suficientemente precisa: é um direito subjetivo diferente daqueles do direito substancial, porque dirigido ao Estado, sem se destinar à obtenção de uma prestação deste. É, antes disso, um direito de iniciativa e de impulso, direito do particular de pôr em movimento o exercício de uma função pública, através da qual espera obter a tutela de suas pretensões, dispondo, para tanto, dos meios previstos pela lei para defendê-las (embora sabendo que o resultado poderá ser-lhe desfavorável)".

${ }^{331}$ Para EDUARDO COUTURE, Fudamentos del derecho procesal civil, p. 58: "Una teoría que trate de explicar la naturaleza jurídica de la acción (el 'qué es la acción') debe partir de la base necesaria de que cualquier súbdito tiene derecho a que el órgano jurisdiccional competente considere su pretensión expuesta con arreglo a las formas dadas por la ley procesal. Ese derecho es la porción mínima indiscutible de todo este fenómeno: el derecho a la prestacion de la jurisdicción". O processualista uruguaio seguiu a linha dos teóricos abstratistas do direito de ação, que têm em DEGENKOLB seu principal expoente, e associou o direito abstrato de ação ao direito de petição. A teoria abstratista do direito de ação conta com numerosos adeptos no Brasil, dentre os quais destacam-se MACHADO GUIMARÃES, JOSÉ FREDERICO MARQUES, ALFREDO BUZAID, entre outros. Para uma visão panorâmica do posicionamento da doutrina a respeito do tema, tanto a brasileira como a estrangeira, v. ADA PELLEGRINI GRINOVER, As garantias constitucionais do direito de ação pp. 53-68.
} 
subjetivo afirmando que ele "é um poder, atribuído pela norma jurídica, e tutelado pela ordem jurídica, de exigir de outrem um determinado comportamento"332. Essa definição, além de ser mais clara que a de FAZZALARI, tem a vantagem de não precisar explicar o alcance do vocábulo bem, utilizando desde já a palavra comportamento.

A partir dela pode-se entender a ação como um direito, porque ela confere ao seu titular o poder de exigir um comportamento do Estado. Tal comportamento é a resposta ao seu pedido de tutela jurisdicional ${ }^{333}$ e esse poder é conferido pela lei e tutelado pela ordem jurídica ${ }^{334}$.

Não sendo nossa intenção formular um estudo dogmático sobre a natureza da ação, a fim de comprovar (ou não) o acerto da doutrina que admite sua caracterização como um direito subjetivo, deixaremos de nos aprofundar no tema para não nos distanciarmos dos objetivos deste estudo.

Interessa-nos, para a compreensão dos direitos processuais adquiridos, apenas a demonstração de que existe uma proteção subjetiva conferida às partes no processo, que lhes permite exigir um comportamento de outros sujeitos no processo. Quando se confere às partes um poder de exigir um comportamento do juiz, está-se garantindo a elas uma proteção contra possíveis arbitrariedades de quaisquer pessoas. Essa garantia é pessoal e não se refere a uma situação jurídica. E é justamente essa proteção que será o núcleo dos direitos processuais adquiridos. A questão de denominá-la direitos ou de poderes

\footnotetext{
332 “Direito subjetivo, pretensão e ação”, p. 113. Na fórmula de PEROZZE apenas não constava a menção de que o poder deve ser tutelado pela ordem jurídica.

${ }^{333}$ Deixaremos para um momento oportuno a análise da amplitude da proteção ao direito de ação prevista na constituição e sua vinculação ou não à tutela jurisdicional.

${ }^{334}$ Devemos mencionar que MOREIRA ALVES somente entendeu a ação como um direito, se consideradas as posições entre autor e réu. Nesse sentido, admitiu, com fundamento nas lições de CHIOVENDA, que a ação seria um direito potestativo. Do ponto de vista da relação autor-Estado, a ação seria uma faculdade, porque "o Direito subjetivo é um poder que se dirige contra alguém para satisfação daquele poder, portanto em benefício do titular daquele poder". Depois de fazer essa afirmação, prosseguiu demonstrando que o autor provoca o Estado para prestar jurisdição, e a jurisdição não seria prestada para a satisfação do autor, que poderia até mesmo vir a ser prejudicado por ela. Discordamos dessas conclusões, porque não nos parece que o resultado do processo deva ser considerado para o fim de verificar o benefício advindo com a provocação da jurisdição. Sempre que o autor faz uso desse poder, o que ele pode exigir é uma resposta, e é essa que será apta a satisfazer o direito de ação do autor, independentemente do seu resultado.
} 
não tem maior relevância para o direito intertemporal, sendo tema afeto à filosofia do direito ${ }^{335}$.

\subsection{Posições jurídicas das partes}

Para que se possa compreender o alcance dos direitos processuais adquiridos é essencial diferenciar quais as posições jurídicas das partes que lhes conferem poderes e quais não, porque a proteção subjetiva para suas posições jurídicas está intimamente relacionada à possibilidade que elas têm de exigir um comportamento de outrem.

A doutrina costuma analisar as posições jurídicas das partes a partir de sua classificação em posições jurídicas ativas e passivas.

São posições jurídicas ativas as que Ihes permitem praticar um determinado ato ou exigir que outro sujeito processual pratique algum ato $^{336}$. As que se referem a uma liberalidade das partes são denominadas faculdades ${ }^{337}$, as demais são chamadas poderes ${ }^{338}$.

As posições jurídicas passivas são aquelas que impelem o sujeito a praticar algum ato ${ }^{339}$. Dividem-se em ônus e deveres ${ }^{340}$.

\footnotetext{
${ }^{335}$ Servimo-nos para justificar essa afirmação das palavras de LIEBMAN: “Delineata cosi da tutti i lati la figura dell'azione, diventa questione puramente terminologica quella che consiste nel sapere se debba qualificarsi diritto soggettivo o potere. Certo è che essa rappresenta, nel sistema delle norme processuali, la figura corrispondente a quella del diritto soggettivo nel sistema delle norme sostanziali. Non le disdice dunque la qualifica di diritto soggettivo processuale" (“L’azione nella teoria del processo civile”, p. 48).

${ }^{336}$ DINAMARCO, Instituições..., vol. II, p. 201.

${ }^{337}$ Definição bastante clara do conceito de faculdade é a fornecida por CARNELUTTI, para quem elas são "possibilidade de realização no campo da liberdade" (Sistema..., vol. I, p. 117).

${ }^{338}$ Ensina DINAMARCO, Instituições..., vol. II, p. 206 que poder é a "capacidade de produzir efeitos sobre a esfera jurídica alheia”. Os poderes estão sempre associados a uma faculdade que o seu titular tem de utilizá-lo ou não.

${ }^{339}$ DINAMARCO, Instituições..., vol. II, p. 201.

${ }^{340}$ COUTURE analisa os imperativos jurídicos que são impostos às partes no processo classificando-os em três grupos, deveres, obrigações e ônus. Ao tratar das obrigações, refere-se às consequiências de ordem pecuniária impostas às partes no processo, como a condenação em custas e honorários ou as decorrentes do abuso de direito, que gera o dever de indenizar a parte contrária. Além dessas, inclui no rol das obrigações as conseqüências de atos dispositivos, como a desistência ou a concordância do réu com o pedido do autor (Fundamentos..., pp. 171-173).
} 
Seguindo os ensinamentos de GOLDSCHMIDT ${ }^{341}$ os ônus são habitualmente conceituados como imperativos do próprio interesse. Referemse a posições jurídicas que colocam a parte em posição de ter que praticar algum ato para evitar uma posição de desvantagem no processo.

Eles podem ser classificados em absolutos e relativos de acordo com as conseqüências de sua inobservância pela parte. Absolutos são aqueles necessariamente acarretam conseqüências quando de sua inobservância e relativos os que não necessariamente acarretam para a parte uma posição de desvantagem em razão de não tê-lo cumprido ${ }^{342}$.

Os deveres processuais das partes, por sua vez, podem ser entendidos como uma limitação à liberdade de atuar imposta em favor de outrem $^{343}$, limitação essa que pode tanto compreender a necessidade de fazer algo (facere) como de abster-se de uma ação (non facere).

Para que se possa entender as posições jurídicas das partes é necessário se atentar para o que elas têm de essencial em sua definição, porque muitas vezes uma ou mais dessas situações se confundem no momento de praticar um único ato. Pensemos, por exemplo, na possibilidade que a parte tem de recorrer. Essa possibilidade é, antes de tudo, uma faculdade. Cabe à parte escolher livremente se irá ou não apresentar o seu recurso. Além de ser uma faculdade ela também é um ônus, porque se não for cumprida ocorrerá a perda da oportunidade de recorrer (preclusão). Uma vez que a parte apresente 0 recurso, nasce para ela o poder de exigir uma resposta do órgão responsável pela sua análise. Por fim, ao redigir esse recurso a parte tem que observar os deveres de boa-fé e lealdade processual.

\footnotetext{
${ }^{341}$ Direito processual civil, p. 17. CARNELUTTI refere-se aos ônus processuais para definir o fenômeno em que "o exercício de uma faculdade aparece como condição para obter uma determinada vantagem; por isso o ônus é uma faculdade cujo exercício é necessário para a obtenção de um interesse” (Sisitema..., vol. I, p. 119).

342 DINAMARCO, Instituições..., vol. II, pp. 205-206.

${ }^{343}$ COUTURE associa os deveres das partes com os interesses do processo e explica que tanto às partes do processo são impostos deveres, como aos auxiliares da justiça e ao próprio juiz (Fundamentos..., p. 172).
} 
Dessas posições jurídicas as únicas que têm importância para o direito intertemporal são os poderes e os ônus, porque as faculdades puras $^{344}$ devem ser entendidas como simples liberalidades do legislador. Elas não se contrapõem a qualquer posição jurídica dos demais sujeitos processuais e podem ser atingidas por lei posterior sem maiores conseqüências para a segurança das partes ${ }^{345}$. Justamente por isso não são protegidas contra alterações legislativas futuras. Os deveres, por sua vez, têm que ser entendidos apenas em posição contraposta aos poderes, já que serão esses que receberão tutela do direito intertemporal ${ }^{346}$.

Quando pensamos na relevância dos ônus para o direito intertemporal devemos diferenciar aqueles que são cumpridos dos que são descumpridos.

O cumprimento de um ônus pode gerar para a parte tanto um poder como uma expectativa. O poder surge quando a parte cumpre um ônus que abre caminho para a prática de um ato do juiz, que consiste em uma resposta obrigatória a esse ato. Assim, quando a parte protocola um recurso ou apresenta uma reconvenção nasce para ela o poder de exigir que o juiz analise e julgue o recurso ou a reconvenção.

Existem alguns ônus cujos cumprimentos geram para a parte apenas uma expectativa com relação ao resultado do processo ou do próprio pedido contido no ato pelo qual esse ônus foi cumprido. Evidentemente apenas os ônus que geram para a parte um poder é que serão objeto de proteção

\footnotetext{
${ }^{344}$ As faculdades puras são as que não estão associadas a outras posições jurídicas das partes e o seu exercício (ou a abstenção desse) não acarreta quaisquer consequiências para o processo. Ensina DINAMARCO que elas são bastante raras e de pouca importância para a definição do processo (Instituições..., vol. II, p. 203).

${ }^{345} \mathrm{Um}$ dos cânones da teoria de GABBA consiste em "non potersi dare diritto acquisito a che non venga emanata una legge nuova, la quale regoli una materia finora non contemplata affatto dalla legislazione". Explicando-a afirmou o mestre italiano que "non può cioè un cittadino ragionavelmente pretendere che per non essere stata vincolata finora la sua libertà in un dato argomento, non lo deba nepur essere in avvenire, senza che rimanga violato un suo diritto di libertà, acquistato soltanto per non avere la legge finora considerato quell'argomento nè esplicitamente nè implicitamente, nè direttamente nè indirettamente" (Teoria della Retroattività..., vol I, p. 205).

${ }^{346}$ De igual forma, caso se admita a existência de três imperativos dirigidos às partes, incluindo as obrigações processuais, a proteção do direito intertemporal voltar-se-á para o seu contraposto que são os direitos da outra parte.
} 
para o direito intertemporal, porque essa proteção dirigir-se-á para o próprio poder e não para o ônus em si. As expectativas não geram poder e não são objeto de proteção $^{347}$.

Isso significa, que ao cumprir com um ônus que apenas favoreça a sua posição processual, como, por exemplo, a apresentação de memoriais, a realização de sustentação oral ou até mesmo a produção de uma prova, a parte apenas traz novos elementos para que o juiz acolha a sua pretensão. Às expectativas que as partes têm em função desse cumprimento não corresponde qualquer novo dever do juiz, que permanecerá tendo que dar uma única resposta, imparcial e fundada no seu livre convencimento. A parte não pode exigir que o juiz julgue de determinada forma por entender que sua posição processual é vantajosa. Daí não decorre que a resposta do juiz seja absolutamente livre e desvinculada dos elementos constantes dos autos. A partir do momento em que o Estado se compromete a tutelar a sociedade e confere às partes os direitos de ação (e de defesa), ele deve dar uma resposta justa ao litígio, o que implica no dever de dar uma resposta fundamentada e baseada nos elementos constantes dos autos.

A fundamentação e a tomada em consideração desses elementos são garantias inerentes ao direito de ação (e de defesa) ${ }^{348}$ e devem ser entendidas dentro desse contexto para o direito intertemporal. Assim, ainda que se considere essa necessidade de fundamentação, não se pode deixar de notar que o dever do Estado continua sendo único. Não é possível falar, com relação ao resultado do processo, que o Estado fique em uma posição de desvantagem na qual o juiz encontre-se subordinado a julgar de determinada forma em função dos elementos constantes dos autos. A posição do juiz em

\footnotetext{
${ }^{347}$ É possível encontrar posicionamento doutrinário que confere uma amplitude muito maior aos direitos subjetivos processuais, como se verifica na construção de GOLDSCHMIDT para quem os direitos processuais são as expectativas, possibilidades e liberações de um ônus processual (Direito processual civil, p. 167). Contudo, o processualista alemão partia da idéia de situação jurídica e não de relação jurídica e, entendia a existência desses direitos sem que houvesse a contrapartida de um dever por parte do Estado (Direito processual civil, p. 168, e Princípios gerais do processo civil, pp. 53-64, esp. p. 54-55).

${ }^{348}$ Esse entendimento afina-se com os ensinamentos de BEDAQUE, Direito e processo, p. 82, que leciona: "a tutela constitucional da ação compreende todos os meios para a obtenção do pronunciamento do juiz sobre a própria pretensão. Não se trata, obviamente, de mera garantia de acesso, compreendendo outros mecanismos destinados a assegurar um processo justo e efetivo".
} 
relação à sentença não pode ser comparada à do enxadrista que é colocado em xeque para o qual só tenha um único movimento a fazer, porque ele permanecerá tendo a possibilidade de se convencer do ponto de vista contrário ao da parte que entende que se encontra em posição francamente favorável em relação ao resultado do processo ${ }^{349}$.

Já do descumprimento de um ônus três situações distintas podem ocorrer. A primeira delas é o trânsito em julgado da sentença. Se o ônus que a parte deveria cumprir era a apresentação de um recurso contra uma sentença (ou acórdão que tivesse decido a fase cognitiva do processo), da perda de oportunidade para recorrer ocorre o trânsito em julgado e o conseqüente término da fase de conhecimento do processo. O trânsito em julgado da sentença é, em si, uma situação jurídica nova e a lei que venha a alterá-la será retroativa. Mas, além da análise objetiva dessa situação jurídica, a coisa julgada gera direitos para o seu titular que são protegidos constitucionalmente.

Prosseguindo na análise do descumprimento dos ônus ditos absolutos $^{350}$ a segunda situação que pode ocorrer é a preclusão. Estamos nos

\footnotetext{
349 Retomamos novamente os ensinamentos de GOLDSCHMIDT, para quem: "Mesmo quando uma expectativa processual estivesse tão segura que equivalesse a uma exigência material, sua frustração representaria 'infração da lei' somente no sentido de 'aplicação indevida' ou 'interpretação errônea' da lei (art. 1692, n.1 da Lei de Ajuizamento Civil) como medida do juízo, mas não lesão de um direito ou 'antijuricidade', no sentido de contravenção de um imperativo jurídico que constitui a obrigação correlativa do direito lesionado. Do ponto de vista processual, os atos judiciais, especialmente as resoluções, são, em todo o caso, equivocados, não antijurídico; referidos ao sujeito, pode existir erro, não culpabilidade" (Princípios..., p. 54). Convém explicar que não é nossa intenção afirmar que o juiz tenha a faculdade de julgar conforme achar conveniente, o poder que ele exerce de julgar é sem dúvida um poder-dever e está estritamente vinculado aos elementos constantes dos autos. Ocorre que direito não é matemática em que os resultados são únicos e inquestionáveis. O dever do juiz contido no seu poder de julgar não pode ser entendido como contraposto a um poder da parte de exigir um determinado resultado do processo. O que ela pode exigir é um resultado que se fundamente em parâmetros de justiça, mas esse poder já está contido no poder de ação.

${ }^{350}$ Utilizamos a palavra ditos para ressalvar que não somos partidários dessa classificação, não ao menos com a extensão que a doutrina costumeiramente lhe dá. Cada vez mais a doutrina moderna confere maiores poderes ao juiz para afastar preclusões, até mesmo sobre ônus entendidos como absolutos como o do autor de alegar na petição inicial todas as causas de pedir que fundamentam a sua pretensão. Nesse sentido, v. BEDAQUE, Efetividade do processo..., pp. 131-135. Em termos de aspectos formais (lato sensu) do ato processual certamente o tempo para o seu cumprimento é o requisito para o qual a doutrina confere menor possibilidade de relativização, mas, em recente tese de doutorado defendida na Faculdade de Direito da Universidade de São Paulo, BRUNO SILVEIRA DE OLIVEIRA, O juízo de identificação de demandas e de recursos no processo civil brasileiro (contribuição ao estudo dos atos postulatórios), pp. 177-184, demonstrou que a perda de um prazo para apresentação de recurso contra uma decisão interlocutória não deve obstar o conhecimento desse recurso, se a questão nele tratada não for passível de preclusão e, ainda, se o conhecimento dela somente em recurso de apelação puder acarretar prejuízos para o bom andamento do processo e administração da justiça. Embora esse último exemplo não diga respeito a um ônus absoluto,
} 
referindo a uma preclusão simples, que apenas acarreta a perda de uma oportunidade de participação sem ocasionar o trânsito em julgado, que foi destacado acima. Deixemos de lado as discussões sobre a amplitude das preclusões inexoráveis no processo e admitamos que elas são realmente tão amplas quanto a doutrina tradicional afirma.

Independentemente do alcance que se dê para o instituto das preclusões, o que elas geram é apenas a estabilização de uma determinada situação jurídica ${ }^{351}$. Elas não se referem à parte contrária e não podem ser associadas a qualquer direito ou poder do adversário de exigi-las. Da própria noção de ônus como imperativo do próprio interesse pode-se concluir que eles não são voltados para a parte contrária e o seu cumprimento ou descumprimento não pode gerar direitos ou poderes para aqueles que estão em situação oposta na demanda. As conseqüências do não cumprimento de um ônus dirigem-se exclusivamente para a parte que tinha a incumbência de praticar o ato.

Daí decorre que não é possível associar o descumprimento de um ônus processual com a idéia de direitos processuais adquiridos. Pensemos no exemplo da falta de apresentação tempestiva de exceção de incompetência pelo réu. Não tendo ele cumprido com esse ônus a competência considera-se prorrogada e ele não terá mais oportunidade para pretender que outro juízo julgue a demanda. Se no curso dessa sobrevier uma lei que confira aos réus a faculdade de excepcionar a competência antes do julgamento de primeiro grau, essa lei não poderá ser aplicável aos processos pendentes em que o prazo para excepcionar a competência já tenha se esgotado, mas isso não decorre da existência de um direito processual adquirido por parte do autor. A ineficácia dessa nova lei é conseqüência de sua irretroatividade, pois, se ela viesse a atingir os processos pendentes, acabaria por alterar uma situação jurídica consolidada em função da

achamos conveniente citá-lo, porque a conseqüência da inimpugnabilidade da decisão interlocutória após a perda do prazo sempre foi afirmada pela doutrina como uma decorrência necessária da inobservância do ônus de recorrer tempestivamente.

${ }^{351}$ É curioso que SALVATORE SATTA, Diritto processuale civile, p. 239, chegou a explicar a natureza jurídica das preclusões como sendo a de uma situação jurídica. Em que pese o equívoco dessas lições, que deixam de examinar a relação de causa e efeito entre preclusões e situações jurídicas, servem para confirmar que o não cumprimento de um ônus (absoluto) acarreta o surgimento de uma situação jurídica. 
preclusão da oportunidade para impugnar a competência relativa por parte do réu ${ }^{352}$.

Em termos de direito intertemporal tem-se, portanto, que o descumprimento de um ônus não gera direitos processuais adquiridos para a parte contrária, sendo de ordem objetiva a proteção que impossibilita a nova lei de alterar a situação advinda desse descumprimento.

Essa afirmativa pode parecer paradoxal com a feita um pouco acima, sobre o descumprimento do ônus de recorrer e o surgimento de um direito para a parte contrária, relativo à coisa julgada. Mas é importante diferenciar os fenômenos. Embora seja um pressuposto para a formação da coisa julgada, a preclusão não se confunde com ela. Tem-se daí que da preclusão da oportunidade de recorrer surge uma situação jurídica consistente na impossibilidade da sentença (ou acórdão) vir a ser alterada por outra decisão no processo. Tal situação mereceria proteção exclusivamente objetiva do ponto de vista do direito intertemporal se se referisse exclusivamente ao processo em que se formou, mas, quis o sistema que ela desse origem a uma proteção maior que é a coisa julgada (material) que projeta efeitos para fora do processo e impede que o comando da sentença e seus efeitos sejam questionados em um processo futuro. Essa proteção maior, que é a coisa julgada em seu aspecto material, é a que gera direitos adquiridos para a parte vencedora da demanda. Trata-se de fenômeno distinto da preclusão ${ }^{353}$, que tem tratamento próprio e não pode ser confundido com as demais conseqüências para o descumprimento de outros ônus processuais.

\footnotetext{
${ }^{352}$ Analisando a introdução do $\S 4^{\circ}$ ao artigo 515, do Código de Processo Civil, que permite aos Tribunais determinarem a regularização de nulidades sanáveis no recurso de apelação, entende CASSIO SCARPINELLA BUENO, Curso sistematizado de direito processual civil, vol. 1, pp. 429-430, que a regra é aplicável aos processos pendentes, porque não haveria para a parte beneficiada pelo reconhecimento da nulidade "direito adquirido" ao não saneamento. Concordamos com essa afirmação no tocante à inexistência do "direito adquirido" ao não saneamento. Do ponto de vista da possibilidade de utilização do dispositivo aos processos pendentes, parece-nos que a solução não deve partir do enfoque do direito intertemporal, já que sua utilização se daria de forma retroativa. Para que se possa sustentar a possibilidade de os Tribunais determinarem a regularização de nulidades sanáveis nos processos pendentes, a resposta deve seguir a linha do uso racional da técnica das preclusões em consonância com os objetivos do processo (v. por todos, BEDAQUE, Efetividade..., pp. 124 e ss.).

${ }^{353}$ Para ampla análise das diferenças entre os institutos, v. os ensaios de CHIOVENDA, "Cosa giudicata e preclusione" e "Cosa giudicata ecompetenza" e MAURÍCIO GIANNICO, A preclusão no direito processual civil, pp. 95-101.
} 
Por fim, a terceira situação relativa ao não cumprimento de um ônus é a que decorre da inobservância de um ônus relativo. Como eles não geram preclusões quando as partes deixam de cumpri-los, a única conseqüência de sua inobservância é colocar a parte em uma situação de risco de ser prejudicada ${ }^{354}$. Não advém de sua inobservância qualquer situação jurídica consolidada, muito menos um poder ou direito da parte adversa, razão pela qual ela não tem importância para o direito intertemporal.

\subsection{Poderes das partes dirigidos ao juiz}

Fixada a idéia de que os direitos processuais adquiridos referem-se a posições jurídicas que permitem às partes exigir um determinado comportamento de outro sujeito processual, impõe-se agora fazer a delimitação de quais desses poderes são efetivamente protegidos pelo direito processual intertemporal.

Para tanto, entendemos ser conveniente fazer dois cortes no nosso objeto de análise. O primeiro servirá para separar os poderes das partes dirigidos ao juiz dos poderes (e direitos) dirigidos à parte adversa.

Ao estudarmos a relação entre as partes e o juiz, convém primeiramente verificar como a doutrina costuma entender a extensão do direito de ação garantido na Constituição Federal, e como ela deve ser entendida para o direito intertemporal. A partir dessa análise ficará mais fácil compreender os desdobramentos desse poder dentro do processo e identificar quais os poderes das partes que são passíveis de gerar direitos processuais adquiridos e quais não.

${ }^{354}$ DINAMARCO, Instituições..., vol. II, p. 206. 


\subsubsection{O direito de ação e o direito intertemporal}

Como se sabe, em tempos antigos a ação era entendida como sendo o próprio direito subjetivo material deduzido em juízo ${ }^{355}$. Com a evolução do direito processual e os estudos sobre a relação jurídica que se estabelece dentro do processo entre autor, juiz e réu essa concepção foi abandonada e a doutrina passou a criar teorias sobre o direito de ação ${ }^{356}$. WACH entendeu-a como um direito autônomo, mas concreto. O direito de ação seria 0 direito de reclamar (klagen) do Estado a tutela jurídica para um direito subjetivo. Ele era entendido como sendo distinto do direito material, por ser um direito público subjetivo dirigido contra o Estado, mas estava demasiadamente vinculado àquele, já que somente teria direito à tutela estatal, e conseqüentemente ao direito de ação, quem fosse efetivamente titular do direito subjetivo.

Em oposição a essa corrente DEGENKOLB desenvolveu na Alemanha a teoria da ação como direito abstrato ${ }^{357}$. Para ele o direito de ação não teria ligação com o resultado do processo. A ação não era o direito de receber tutela para um direito subjetivo, mas o direito de receber uma resposta do judiciário. Essa teoria foi chamada de teoria abstrata do direito de ação, ou teoria abstratista pura, porque os seus defensores não faziam qualquer ressalva quanto ao conteúdo da sentença. O direito de ação seria apenas o direito a uma sentença, e seria incondicionado, pois existiria ainda que o juiz não analisasse o mérito da pretensão deduzida em juízo.

Buscando aperfeiçoá-la, LIEBMAN desenvolveu sua própria teoria, chamada eclética, porque une elementos das principais teorias até então existentes. O processualista italiano enxergou a ação como o direito ao processo e ao julgamento do mérito. Ao fazê-lo, diferenciou o poder genérico, inexaurível e

\footnotetext{
${ }^{355}$ Informa GALENO LACERDA, Teoria geral do processo, p. 211, que "esta concepção nasceu de fontes romanas. Baseou-se na célebre frase de CELSO: Actio nihil est quam jus persequendi in judicio quod sibi debetur".

${ }^{356}$ A polêmica sobre a caracterização ou não da ação como um direito já foi analisada acima, tendo-se, inclusive, demonstrado que para o direito intertemporal a questão de saber se ela é um direito subjetivo ou um poder não é relevante. Por isso, doravante quando mencionarmos o direito de ação, estaremos utilizando um sentido amplo para a expressão, que engloba as duas teorias.

${ }^{357}$ Paralelamente o processualista húngaro PLÒSZ criava teoria bastante parecida com a de DEGENKOLB.
} 
inconsumível de se dirigir ao Poder Judiciário do verdadeiro direito de ação, que é atribuído para a tutela de direitos e somente se configura quando o juiz profere uma sentença de mérito, acolhendo ou negando o pedido do autor ${ }^{358}$. Na teoria de LIEBMAN o direito de ação permanece sendo autônomo e abstrato, porque existe mesmo se o autor não tiver o direito material alegado na petição inicial, porém esse direito não é incondicionado. Como o direito de ação se configura por ser um direito a uma sentença sobre o mérito, é necessário que a demanda preencha determinados requisitos para que o autor tenha o direito de ação. Esses requisitos são as condições da ação, que para LIEBMAN seriam um elo de ligação entre o direito material e o direito de ação ${ }^{359}$.

No ordenamento brasileiro o direito de acesso ao Judiciário está previsto no art. $5^{\circ}$, inc. XXXV, da Constituição Federal, da seguinte maneira "a lei não excluirá da apreciação do Poder Judiciário lesão ou ameaça a direito".

O texto do dispositivo não é dos melhores e uma interpretação literal poderia sugerir que nosso constituinte aderiu à teoria concretista de $\mathrm{WACH}$, já que ele afirma que somente os direitos ameaçados ou lesionados é que não podem ser afastados da apreciação do Poder Judiciário. Mas, para que se possa permitir que os direitos sejam tutelados é necessário, antes de mais nada, que se garanta a todos o livre acesso ao Judiciário, independentemente da existência ou não do direito para o qual será pedida a proteção judicial. Na grande maioria dos casos o juiz não tem elementos desde o início da demanda para saber se vai julgá-la improcedente. Por outro lado, mesmo quando o juiz não acolhe o pedido do autor ele é obrigado a proferir uma sentença e, se estiverem presentes os pressupostos processuais e as condições

\footnotetext{
${ }^{358}$ Essas são resumidamento as principais doutrinas acerca do direito de ação, traçadas a partir das lições de GALENO LACERDA, Teoria geral do processo, pp. 210-229; PAULO DE FREITAS, Direito processual subjetivo, pp. 13-30; GRINOVER-CINTRA-DINAMARCO, Teoria geral do processo, pp. 249-253; DINAMARCO, Fundamentos do direito processual civil, tomo I, pp. 277-285; EDUARDO COUTURE, Introducción al estudio del proceso civil, pp. 6-24 e RODRIGO CUNHA LIMA FREIRE, Condições da ação - enfoque sobre o interesse de agir no processo civil brasileiro, pp. 39-45. Além das teorias citadas, deve-se mencionar a de CHIOVENDA, que entendia a ação como um direito potestativo dirigido contra o réu (Principii di diritto processuale civile, pp. 43-53). Deixamos de mencioná-la no corpo do texto porque nossa intenção é analisar o conteúdo da ação como poder dirigido contra o Estado, tal qual assegurado no art. $5^{\circ}$, inc. XXXV, da Constituição Federal.

${ }^{359}$ Manual..., vol. I, pp. 148-152 e “L’azione nella teoria del processo civile”, pp. 46-47.
} 
da ação, essa sentença terá que analisar o mérito da demanda e fará coisa julgada material, tutelando o direito do réu e pacificando as partes ${ }^{360}$.

Por essas razões a teoria concretista da ação não conta com muitos adeptos na doutrina brasileira, travando-se as principais discussões acerca do conteúdo do direito de ação garantido na Constituição em torno das teorias abstratista pura e eclética ${ }^{361}$.

Vejamos como os poderes conferidos às partes em cada uma dessas teorias se comportam no direito intertemporal.

Para os abstratistas puros o direito de ação consiste no direito de acesso aos órgãos do judiciário. Nesse grau de amplitude, a parte tem o poder de provocar o órgão judicial e exigir dele uma resposta fundamentada para a petição inicial. Ainda que o juiz entenda que não irá julgar o mérito da demanda, o autor tem direito de saber o motivo dessa negativa, o que também decorreria do direito de petição dirigido contra órgão do Poder Judiciário ${ }^{362}$.

A teoria não traz maiores conseqüências para o direito intertemporal, porque não é razoavelmente possível vislumbrar conflito de leis no tempo que se dirija exclusivamente para uma limitação desse amplo poder de provocar a atividade jurisdicional. De fato, para que fosse possível haver um problema de direito intertemporal envolvendo o direito de acesso aos órgãos do judiciário, necessário seria que uma lei nova atingisse o direito que a parte tem de obter uma resposta do Poder Judiciário ou que permitisse que essa resposta não fosse fundamentada. Do primeiro caso não se deve cogitar, porque uma lei que

\footnotetext{
${ }^{360}$ A tutela jurisdicional normalmente é entendida como uma proteção conferida ao vencedor da demanda, mas como demonstra YARSHELL, Tutela jurisdicional, pp. 35-37, em um sentido mais amplo, ligado à idéia de pacificação social, a tutela jurisdicional dirige-se tanto ao vencedor como ao vencido em virtude da eliminação do conflito por meio da coisa julgada material.

${ }^{361}$ V. SUSANA HENRIQUES DA COSTA, Condições da ação, pp. 47-52.

${ }^{362}$ COUTURE, Introducción..... 18-22; JOSÉ FREDERICO MARQUES, Instituições..., vol. II , p. 8. Devese frisar, com apoio nas lições de BEDAQUE, Direito e processo, p. 82, que mesmo os defensores de uma maior amplitude do direito de ação, que realmente admitem que o poder de provocar o judiciário e receber uma resposta para essa provocação, independentemente da análise do mérito, já é suficiente para caracterizar o direito de ação, não o desvinculam completamente do direito material. Assim, ainda que não haja a análise do mérito, a pretensão da parte deve estar associada a algum pedido de tutela para uma crise qualquer de direito material.
} 
permitisse ao juiz o non liquet seria claramente inconstitucional por atentar contra fundamentos básicos do Estado Democrático de Direito ${ }^{363}$, além de ser uma teratologia. Do segundo também não, já que qualquer lei que viesse a permitir que o juiz deixasse de fundamentar, ainda que minimamente, sua decisão seria inconstitucional, em virtude da proteção constante do art. 93, inc. IX, da Constituição que determina que todas as decisões dos órgãos jurisdicionais sejam fundamentadas ${ }^{364}$.

Fica claro, assim, que para o direito intertemporal a teoria eclética da ação é a que deve ser levada em consideração para fins de delimitação dos direitos processuais adquiridos.

Segundo essa teoria, desde que o Estado suprimiu o poder de autotutela das partes, surgiu para ele o dever de pacificar a sociedade mediante a prestação da tutela jurisdicional. A tutela jurisdicional tanto pode ser conferida para o autor como para o réu, dependendo de quem tenha razão (na realidade, de quem se sagre vencedor na demanda, porque a atividade jurisdicional está sujeita a erro). Mas o dever do Estado não se refere apenas à resposta que o juiz tem que dar para a petição inicial. Uma resposta genérica, que não analise o mérito da demanda, é destituída de sentido para o direito processual e não tem ligação direta com a parcela de liberdade que foi subtraída dos particulares no momento em que foi proibida a autotutela. Assim, o direito de ação é direito ao provimento estatal ${ }^{365}$ que irá solucionar a crise de direito material levada ao conhecimento do Estado.

\footnotetext{
${ }^{363}$ Conforme ensina DINAMARCO, desde quando a própria justiça passou a ser vista como um dever e não como um favor ou graça, sendo objeto de solene promessa constitucional (acesso à justiça), os poderes desse sujeito processual (juiz) não são puros poderes, mas poderes-deveres” (Instituições..., vol. II, p. 228-229).

${ }^{364}$ Diante do vazio que sobra quando se associa o direito de ação ao direito de petição, e considerando-se a existência da garantia constitucional de acesso ao Judiciário, grande parte da doutrina costuma afirmar a existência de duas modalidades distintas de direitos. O direito de ação e o direito à ação (PAULO DE FREITAS, Direito processual subjetivo, pp. 106-107), sendo o primeiro o direito de propor a ação e o outro o direito à ação proposta. De maneira similar, TEREZA ALVIM, O direito processual de estar em juízo, pp. 11-12 entende que existem duas espécies de direito de ação, um constitucional, que se afina com a teoria abstratista pura, e outro processual, regulada pelo Código de Processo Civil e correspondente à ação da teoria de LIEBMAN.

365 Mencionamos direito ao provimento estatal que irá solucionar a crise de direito material para incluir tanto o direito de ação visto sob a ótica do processo de conhecimento como executivo.
} 
Esse direito, não é incondicionado. O Estado tem o dever de oferecer aos cidadãos oportunidades amplas de tutela jurisdicional para os direitos, e ele assim faz. Mas a atividade jurisdicional deve prezar pela eficiência de modo que o Estado pode criar requisitos para que o exame do mérito seja analisado. Tais requisitos são as condições da ação que devem estar presentes para configuração do dever estatal de solucionar a crise levada ao seu conhecimento.

A partir dessas noções preliminares fica fácil perceber que, diferentemente do direito de acesso ao Poder Judiciário, o direito de ação permite a existência de problemas de direito intertemporal, já que é um direito condicionado e os limites ao seu exercício são ditados por leis ordinárias, nada havendo nisso de inconstitucional.

\subsubsection{Poderes das partes dirigidos ao juiz e direito processual adquirido}

Nos tópicos precedentes procuramos demonstrar que a proteção de ordem subjetiva contra alterações legislativas no processo refere-se aos poderes das partes e não ao descumprimento de um ônus pela parte contrária.

Além disso, concluímos que para o direito intertemporal esse poder deve ser entendido como o poder de provocar a atividade jurisdicional e exigir um provimento sobre o mérito da demanda, bem como que, por razões de ordem política, o Estado pode limitar o seu exercício, impondo requisitos para o exame do mérito. Resta analisar, agora, o modo como esse poder é disciplinado no processo para que possamos delimitar os direitos processuais adquiridos. 
O direito de ação, visto em sua bilateralidade ${ }^{366}$, confere às partes o poder de exigir do juiz que aprecie seus pedidos de tutela jurisdicional. Tal é o direito fundamental que advém da retirada da possibilidade de as partes se autotutelarem e gera para o Estado o dever de exercer a jurisdição para pacificar a sociedade. Esse dever está expresso na Constituição Federal, mas sequer seria necessário por ser uma decorrência necessária do Estado de Direito $^{367}$.

Tem-se que entender, ademais, que o direito de ação (e de defesa) não consiste somente na possibilidade de provocar o Poder Judiciário e receber uma resposta para a crise de direito material levada ao seu conhecimento. O direito de ação precisa ser compreendido como direito a um processo justo e équo ${ }^{368}$, o que permite às partes exigir, além da solução para a crise de direito material, que essa seja concedida de maneira imparcial, com amplas possibilidades de defesa dos seus interesses, respeitando-se 0 contraditório e a isonomia ${ }^{369}$.

A desnecessidade de constar expressamente da Constituição e a associação do direito de ação com as garantias do devido processo legal não significa, todavia, que estejamos diante de um direito ilimitado.

\footnotetext{
${ }^{366}$ Depois de completada a relação jurídica processual a resposta do juiz pode ser exigida tanto pelo autor como pelo réu, sendo certo que após a apresentação da contestação (ou do decurso do prazo para tanto) o autor sequer pode desistir da ação sem o consentimento do réu (CPC, art. 267, § $4^{\circ}$ ). Nesse estágio a ação deve ser entendida em sua bilateralidade e compreende também o direito de defesa que é contraposto a ela. Nas palavras de CALAMANDREI, "la acción, como actividad dirigida a presentar al juez una propuesta de providencia, no es solamente propia del actor: porque también el demandado, aun cuando se limite a pedir el rechazamiento de la demanda contraria, viene, en sustancia, a solicitar del juez que pronuncie una sentencia de declaración negativa de mera certeza, esto es, una providencia diversa de la pedida por el actor, y favorable, en lugar de a éste, a él como demandado" (Instituciones de derecho procesal civl segun el nuevo codigo, vol. I, p. 239).

${ }^{367}$ V. CASIMIRO VARELA, Fundamentos constitucionales del derecho procesal, pp. 90-92, esp. p. 90.

368 Conforme ensina KAZUO WATANABE, “Acesso à Justiça e sociedade moderna”, p. 128: “a problemática do acesso à Justiça não pode ser estudada nos acanhados limites do acesso aos órgãos judiciais já existentes. Não se trata apenas de possibilitar o acesso à Justiça enquanto instituição estatal, $e$ sim de viabilizar o acesso à ordem jurídica justa”. A propósito das garantias que devem compor o processo justo e équo, v. COMOGLIO, “Garanzie costituzionali e 'giusto processo' (modelli a confronto)”, pp. 101 e SS..

${ }^{369}$ Isso porque, "no mesmo nível constitucional em que está a garantia da ação (Const., art. $5^{\circ}$, inc. XXXV), estão também outras garantias que, destinam-se a todos os sujeitos processuais, têm o efeito de dar pesos equivalentes à ação e à defesa (isonomia das partes, contraditório, ampla defesa: v. esp. art. $5^{\circ}$, inc. LV). A ação e a defesa, tanto quanto a jurisdição, exercem-se no processo e a oferta de oportunidades equilibradas para o exercício de ambas constitui exigência do devido processo legal, preordenada à produção da tutela jurisdicional a quem efetivamente tiver razão (processo justo e équo)" (DINAMARCO, Instituições..., vol. I, p. 297).
} 
O que o Estado precisa para garantir os fundamentos do regime democrático subordinado à lei é viabilizar a possibilidade de acesso à justiça para todos os cidadãos. Esse acesso, contudo, não confere às partes o poder de levar seus argumentos e pedidos irrestritamente ao conhecimento do Estado-juiz. O dever do Estado é analisar ao menos uma vez cada pretensão das partes em relação a uma determinada crise de direito material e, ao fazê-lo, solucionar de maneira justa essa crise.

Em sentido amplo, as garantias constitucionais do devido processo legal têm menor importância para o direito intertemporal na medida em que uma lei que venha a feri-las será inconstitucional e não haverá razões para indagar sobre sua eficácia aos processos pendentes ${ }^{370}$. Ela será inaplicável para qualquer processo, tanto os pendentes como os futuros. Assim, por exemplo, se uma lei suprimir por completo o direito de defesa ela será inconstitucional e não ocasionará problemas de sucessão de leis no tempo, porque essa sucessão não ocorrerá. A verificação da compatibilidade de uma lei com o sistema em que ela está inserida é um passo logicamente anterior à análise do modo como uma situação concreta pode ser atingida por duas leis que a regulem, porque, para tanto, é necessário que essas duas leis sejam válidas e eficazes, o que impõe que sejam ambas compatíveis com os princípios e regras do ordenamento.

O que interessa para o direito intertemporal, portanto, é verificar como o direito de ação e de defesa é validamente distribuído e limitado em cada processo, para que se possa identificar quais poderes das partes serão passíveis de aquisição e quais não.

Ao analisarmos a sistemática dos poderes de que as partes são dotadas em juízo veremos que alguns deles são um desdobramento do direito de ação e de defesa e referem-se diretamente ao mérito da demanda,

\footnotetext{
370 Observação análoga foi feita por FAZZALARI: “Ad esempio, la parte può essere arrichita o privata di una facoltà di difesa; col solo limite, in caso di privazione, che la nuova legge non violi il diritto di difesa, cioè il principio del contraddittorio, costituzionalmente presidiato: ma, como ognuno intende, questo è un problema di legittimità costituzionale della legge, non di sua efficacia nel tempo" ("Efficacia della legge processuale nel tempo”, p. 892).
} 
outros, por sua vez, são poderes conferidos pelo legislador para controle da técnica processual, sem que tenham correlação com direta com a ação ou a defesa $a^{371}$. Somente os primeiros é que serão passíveis de aquisição ${ }^{372}$.

Para que possamos compreender essa afirmação é importante termos presente que o direito de ação e de defesa não é exercido em um único momento pelas partes ${ }^{373}$. Em um primeiro momento o autor distribui a demanda contendo os fundamentos para o seu pedido, mas, até a citação do réu ele pode incluir novos fundamentos, mesmo sem a concordância desse. A defesa do réu, por sua vez, pode ser integralmente concentrada em uma única peça, ou dividida em impugnações autônomas. Uma vez que seja citado, pode o sistema autorizá-lo a apresentar reconvenção ou a formular pedido contraposto. controle de algumas garantias inerentes ao direito de ação e de defesa, como a imparcialidade do juiz, também poderá ser feita de maneira incidental. O direito de dirigir a pretensão (e a defesa) ao juiz poderá ser único, ou duplo, com a previsão de um recurso com ampla devolutividade da matéria a ser impugnada. Poderá haver, ainda, a possibilidade de submeter a matéria legal e constitucional que fundamenta o direito das partes para uma corte superior etc ${ }^{374}$..

${ }^{371}$ A propósito das inúmeras demandas formuladas no processo e de suas relações ou não com o mérito, v. DINAMARCO Instituições..., vol. II , pp. 132-134.

${ }^{372}$ É interessante constatar que PEDRO DA SILVA DINAMARCO, ao analisar mais de perto os poderes específicos das partes no processo descreve poderes que podem ser entendidos como desdobramentos do direito de ação e de defesa, tais como o de ação, de contestar, de reconvir, de denunciar a lide, o de recorrer e o de requerer e exigir a produção de provas (Ônus processuais: limites à aplicação das conseqüencias previstas para o seu não-cumprimento), p. 30. De nossa parte, ressalvamos apenas nosso entendimento de que a prova, vista dentro do direito de defesa, não confere à parte o poder de exigir sua produção fora dos casos em que seja pertinente ou necessária. Voltaremos ao tema um pouco mais adiante.

${ }^{773}$ Destacam-se, a propósito, as lições de ROGÉRIO LAURIA TUCCI, Da ação e do processo civil na teoria e na prática, p. 27: "De todo o exposto, neste rápido e despretensioso estudo sobre os mais modernos aspectos do conceito de ação, exsurgem, decerto, o significado e a importância da verificação de duas situações, embora correlatas, de todo inconfundíveis: por um lado, a do sujeito de direitos, pessoa física ou jurídica, de invocar a tutela jurisdicional, quando se veja, qualquer deles, ameaçado ou violado por outrem; e, por outro, a concernente à indispensabilidade de atuação do titular de direito subjetivo material, em prol da respectiva preservação. (...) E nessa efetiva concretização daquele direito, concedido genérica e abstratamente a todos os membros da comunhão social, não há como deixar de considerar-se, outrossim, a já relevada ação das partes - não só o impulso inicial, da jurisdicionalização da pretensão, como também todos os demais atos concernentes à atividade dos sujeitos parciais da relação jurídica litigiosa (ou, eventualmente por seus substitutos processuais), que não obstante instrumental por natureza e definição, se direciona, também, à prestação jurisdicional colimada".

374 JOSÉ FREDERICO MARQUES, Instituições de direito processual civil, vol. II , p. 284, relembra interessante classificação feita por JOSÉ ALBERTO DOS REIS, pela qual o Professor de Coimbra dividia os atos processuais em razão de sua função, da seguinte maneira: “a) atos quanto à lide que se agrupam em atos de introdução, atos de instrução, atos de discussão e atos de decisão; b) atos quanto ao processo, que se distinguem em atos de impulso, atos de formação, atos de governo e atos de resolução". A classificação não é igual à que propomos para diferenciar os atos das partes que lhes geram poderes passíveis de aquisição 
Vê-se, assim, que essas são formas distintas com que o sistema divide o exercício da ação e da defesa no processo, que não se concentram em um único momento para cada parte.

Os poderes relativos a elas e que thes conferem a possibilidade de exigir uma resposta do juiz é que serão passíveis de aquisição pelas partes, os demais não, exceto se advierem de institutos bifrontes, com íntima relação com o direito material, como é o caso da responsabilidade patrimonial $^{375}$.

Para entender os poderes que não são passíveis de aquisição pelas partes, deve-se considerar que o Estado cria um modelo ideal de processo para atingir o objetivo de solucionar as demandas que lhe são dirigidas de maneira justa e eficiente. Ao fazê-lo, desenha um tipo de procedimento, organiza a distribuição da competência e dita uma vasta gama de regras técnicas para auxiliar na sua tarefa, acreditando que elas serão o melhor meio para alcançar seus objetivos.

Visando dar eficiência a esse modelo previamente criado, 0 Estado confere às partes o poder de controlar o cumprimento das regras legais e, enquanto elas estiverem em vigor, as partes terão o poder de dirigir pedidos aos diversos órgãos da jurisdição para exigir sua observância. Ocorre que, se porventura o Estado entender que essas regras não são mais as melhores para atingir os objetivos do processo, ele pode simplesmente suprimir o poder das partes, sem que se possa falar em direitos processuais adquiridos. Isso porque as regras sobre a organização judiciária e o procedimento não são disponíveis para o Estado ${ }^{376}$. Quando ele confere poderes para as partes praticarem atos no

daqueles que não geram esses poderes, especialmente porque nela estão incluídos não só os atos das partes como os do juiz. Contudo, a divisão em atos quanto à lide e atos quanto ao processo é bastante útil para essa compreensão.

${ }^{375}$ Não nos esquecemos de que a própria ação é, em si, um instituto bifronte. Contudo, seu exercício e também o do direito de defesa têm desdobramentos que, para o direito intertemporal, podem ser colocados num plano estritamente processual. São a esses desdobramentos a que nos referimos.

376 Já há muito tempo, JOÃO MONTEIRO proclamava a existência de direito adquirido à ação, mas esclarecia, com fundamento nas lições de GABBA, que "quanto á fórma da acção, ou, como diz Gabba, ao rito processual, a lei nova é em regra retroactiva; applica-se tanto aos direitos adquiridos antes de sua 
sentido de exigir a observância de determinadas regras, ele o faz em benefício próprio, da boa administração da justiça.

Esse poder, portanto, não nasceu para a parte em função de algo que Ihe tenha sido subtraído - como ocorre com a ação, que nasce da proibição da autotutela - e não lhe é conferido de maneira irrevogável. Sua concessão advém de ato de liberalidade do Estado, praticado em benefício próprio e, portanto, passível de revogação ${ }^{377}$.

Para ilustrar o problema podemos imaginar uma demanda em que o réu tenha impugnado a incompetência absoluta do juízo, e tenha o juiz indeferido o pedido de remessa dos autos para outro juízo. O réu, então, interpõe agravo de instrumento pedindo que o Tribunal reforme a decisão. Se antes do julgamento do recurso sobrevier uma lei alterando as regras de competência, determinando que o juízo competente para o julgamento da demanda é aquele que proferiu a decisão impugnada, ter-se-á que a parte não poderá exigir que ela seja julgada pelo juízo anteriormente competente e nem mesmo que o seu recurso tenha o mérito apreciado. A interposição do recurso tempestivamente não gera para ela um direito processual adquirido ao seu julgamento (de mérito), porque a matéria versada no recurso era de livre disposição para o Estado ${ }^{378}$.

promulgação quanto aos que o foram posteriormente; e ainda quanto aos primeiros, applica-se não só aos processos a propôr, como aos pendentes" (Theoria do processo civil, volumes I, II e III, p. 60)

377 Retomando os ensinamentos de GABBA, Teoria della retroattività..., vol. I, pp.210-211: "Affinchè l'individuo possa reputare ingiusta ed intollerabile offesa il disconoscimento di un suo diritto per opera del legislatore, egli è mestieri che l'oggetto e l'utilità di quello concernano propriamente la sua personale o privata individualità".

${ }^{378}$ Para afirmar a inexistência de direito adquirido à competência, a jurisprudência e a doutrina costumam citar a clássica passagem de CARLOS MAXIMILIANO, que afirmou: “consideram-se de interêsse público as disposições atinentes à competência em lides contenciosas; por êste motivo, aplicam-se imediatamente; atingem as ações em curso. Excetuam-se os casos de haver pelo menos uma sentença concernente ao mérito; o veridictum firma o direito do Autor no sentido de prosseguir perante a Justiça que tomara, de início, conhecimento da causa” (Direito intertemporal, p. 263). De nossa parte, achamos que algumas observações precisam ser feitas nessa passagem. Primeiramente, não é o interesse público que impede a aquisição do direito à competência, mas a ausência de uma individualidade que permita concluir que ela pode ser objeto de aquisição pelas partes. As partes nada fizeram para adquirir esse direito e quando o Estado ditou as regras de competência o fez para si e não para elas. Tanto é assim que, quando as regras sobre competência são instituídas em favor das partes (competência relativa), é possível que se tornem objeto de negócios jurídicos processuais e dêem origem a direitos processuais adquiridos, conforme veremos mais à frente. Por outro lado, a perpetuação da competência absoluta quando já foi proferida uma sentença se faz para conferir maior eficiência ao processo, preservando sua unidade. O fenômeno não tem relação com direitos processuais adquiridos, e decorre do afastamento da eficácia imediata da lei para preservação de escopos do processo. 
Diante dessas colocações, pode-se fazer mais um corte para delimitar os direitos processuais adquiridos para afirmar que, dentro dos poderes conferidos às partes no processo, somente aqueles que se referem diretamente ao direito de ação e de defesa, entendidos naquilo que eles têm de relação com o mérito da demanda, é que são passíveis de aquisição pelas partes ${ }^{379}$.

\subsection{Direitos processuais adquiridos e relações entre as partes}

A forma como a relação processual se desenvolve faz com que os sujeitos parciais tenham muito mais relações jurídicas diretas com o juiz, do que entre si. Autor e réu formulam seus pedidos para o juiz e é ele quem os analisa e os decide. As partes estão em posição contrapostas, mas o que interessa a ambas é convencer o juiz de que têm razão. Não tendo havido composição antes de iniciada a demanda, no curso dessa não será mais necessário que uma parte convença a outra de que está com a razão, mas somente ao juiz, pedindo-Ihe que reconheça o seu direito e sujeite a parte contrária a respeitá-lo. Sendo assim, normalmente as partes não se dirigem umas às outras no processo, mas ao juiz.

Isso não significa que as partes não possam fazer tratativas no processo, e nem mesmo que em suas relações diretas com o juiz elas não detenham qualquer dever com a parte contrária.

Durante todo o curso da demanda as partes podem se compor sobre o bem da vida pelo qual litigam, sendo-Ihes facultado pedir a homologação do acordo. Além disso, existe um campo de matérias de ordem

\footnotetext{
379 Deve-se criticar, portanto o entendimento do Supremo Tribunal Federal que, sem se debruçar sobre o conceito de direito adquirido processual afirmou sua existência relativamente à competência absoluta, quando a demanda já tivesse sido sentenciada em primeiro grau (RE 450.504 AgR/MG). A solução de manter a competência para julgamento do recurso junto ao Tribunal hierarquicamente superior ao órgão jurisdicional que sentenciou a demanda pode ser louvada por uma questão de racionalização da atividade jurisdicional, mas não nos parece possível afirmar a existência de um direito adquirido à competência da demanda. Se esse direito efetivamente existisse, ele deveria ser adquirido no momento da propositura da demanda, impedindo, assim, que as alterações sobre competência absoluta surtissem efeitos sobre os processos pendentes.
} 
processual em que o interesse particular é preponderante, a respeito das quais podem as partes pactuar.

Exemplos dessas matérias são a competência relativa (que não diga respeito à conexão); os prazos dilatórios; a possibilidade de pedir a suspensão do processo; e o próprio direito de ação ${ }^{380}$, pois o Código permite que as partes conjuntamente requeiram sua desistência (art. 267, inc. VIII, c/c 158, parágrafo único), o que acarretará a extinção do processo sem resolução do mérito.

Em todos esses casos as partes podem realizar negócios jurídicos processuais que, a teor do disposto no art. 158 do Código de Processo Civil, geram para elas direitos processuais.

Os direitos advindos dos negócios jurídicos processuais são comumente aceitos como passíveis de aquisição e incluídos, assim, no conceito de direitos adquiridos processuais ${ }^{381}$, porque geram para as partes o poder de exigir sua observância pelo juiz ${ }^{382}$.

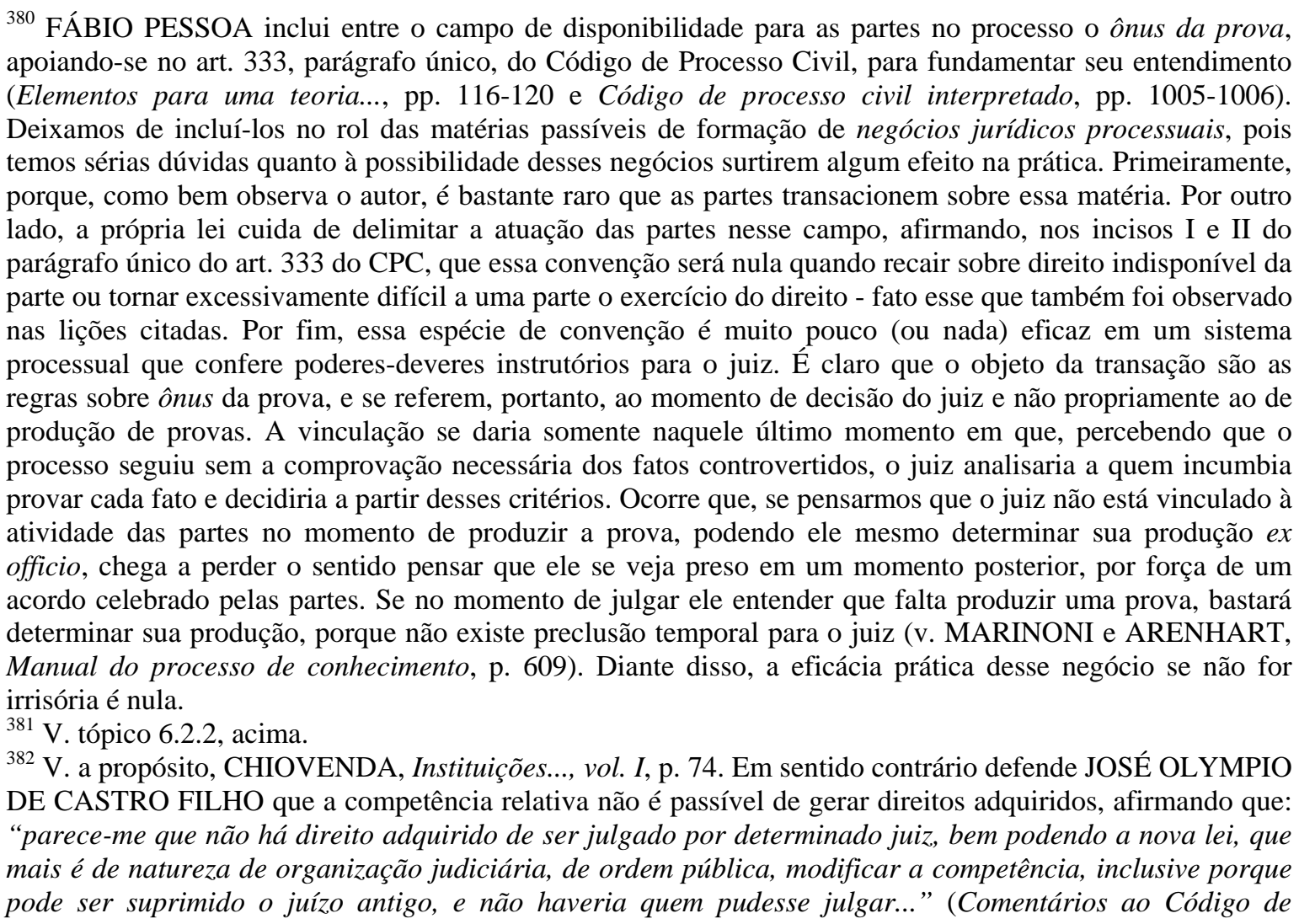


Além dos direitos adquiridos advindos dos negócios jurídicos processuais, deve-se considerar que mesmo quando as partes se relacionam diretamente com o juiz elas precisam observar imperativos de ordem ética. Esses imperativos consistem em deveres que as partes têm umas com as outras e referem-se à boa-fé na forma de litigar. Em que pese ser garantida às partes a ampla defesa dos seus interesses no processo, o sistema preza pelo fair play, impondo limites a essa forma de atuação, conforme se observa dos artigos 14, 15, 17 e 600, do Código de Processo Civil ${ }^{383}$.

O descumprimento de um dever por uma das partes poderá causar dano ao seu adversário, gerando para esse o direito à reparação ${ }^{384}$. A parte também pode ser responsabilizada por pleitear uma tutela de urgência ${ }^{385}$ que, uma vez concedida, seja posteriormente revogada e cause danos à parte

Processo Civil, vol. X, p. 333). Pensamos que é necessário dividir em dois pontos a análise da vinculação que atinge o Estado, para conferir uma resposta mais adequada ao problema. É evidente que as partes não podem impedir o Estado de suprimir um determinado juízo, sendo certo que, sempre que isso ocorrer o acordo celebrado entre as partes não terá o efeito de manter a competência do juízo suprimido para o julgamento da demanda, o que, inclusive, se depreende da leitura do art. 87, parte final, do CPC. A possibilidade de transacionar sobre o poder que o Estado tem de suprimir um determinado juízo não está no alcance das partes e qualquer negócio jurídico nesse sentido seria, no mínimo, ineficaz. Ressalvada essa hipótese, as partes podem livremente pactuar sobre a competência relativa e esse negócio vinculará o Estado, ainda que posteriormente ele entenda por suprimir o poder das partes de transacionar sobre a matéria. Primeiramente porque, conforme demonstrado no tópico 5.2.1, acima, as leis de ordem pública, tanto quanto as demais, devem respeitar os direitos adquiridos. Por outro lado, discordamos que a regulamentação dessa matéria seja de ordem pública. A competência relativa que é passível de tratativa entre as partes insere-se no âmbito de matérias processuais em que há predominância do interesse particular, conforme se depreende do posicionamento majoritário da doutrina., Seu regramento obedece ao interesse das partes, sendo esse, inclusive, o fundamento para que possa haver uma cláusula de eleição de foro em um contrato particular (v., por todos, GRINOVER-SCARANCE FERNANDES-MAGALHÃ̃ES GOMES FILHO, As nulidades no processo penal, pp. 44-45).

${ }^{383}$ São elucidativas as palavras de HUMBERTO THEODORO JÚNIOR, “Abuso de direito processual no ordenamento jurídico brasileiro", p. 107: "Reprime-se, nas leis processuais, o abuso de direito, de forma a eliminar a pior mácula que uma atividade de pacificação social poderia apresentar, a mentira e, conseqüentemente, a injustiça”.

384 "As sanções processuais contidas no art. 18 pela prática de atos tipificados no art. 17 importam a transcendência para o processo civil dos postulados da teoria da responsabilidade civil subjetiva. Assim, a prática pelas partes de atos processuais com dolo ou culpa que tenham causado dano à outra parte faz incidir o dever de indenizar a parte prejudicada" (BRUNELA VIEIRA DE VICENZI, A boa-fé no processo civil, pp. 98-99).

${ }^{385}$ A responsabilidade por um pedido de tutela de urgência pode decorrer do dano ocasionado em função desse pedido, como por ser considerada uma conduta abusiva. Tratando desse segundo aspecto, esclarece HELENA NAJJAR ABDO, O abuso do processo, p. 212, que: "O abuso, nesses casos, verifica-se pela deturpação da finalidade da medida liminar, seja ela de natureza cautelar ou antecipatória. Ocorre quando a parte pretende conseguir, com a medida requerida, outros efeitos que não aqueles intrínsecos a esse tipo de tutela de urgência, ou seja, assegurar a efetividade da tutela final, evitar a ocorrência de dano irreparável ou de difícil reparação". 
contrária (art. 811 do CPC) ou por executar provisoriamente uma sentença que seja modificada (art. 475-O do CPC).

Além desses casos, existe a responsabilidade decorrente da sucumbência. A parte que dá causa à propositura da demanda tem o dever de reparar o prejuízo ocasionado pela necessidade de buscar o cumprimento em juízo e, por isso, deve arcar com as custas e despesas processuais e, ainda, com as verbas de sucumbência ${ }^{386}$.

Em todos esses exemplos a responsabilidade nascida no processo assemelha-se à responsabilidade civil $^{387}$, aquiliana ou objetiva a depender do caso $^{388}$ - e gera direitos que se incorporam ao patrimônio da parte adversa (ou de seu advogado). Esses direitos recebem proteção subjetiva do direito intertemporal e não podem ser suprimidos por lei posterior, ainda que haja previsão expressa de retroatividade.

386 A natureza da condenação em honorários advocatícios é claramente indenizatória (v. YOUSSEF CAHALI, Honorários advocatícios, pp. 38-40). Justamente por isso deve-se criticar a opção do legislador ao afirmar no art. 23 da Lei 8.906 de 4 de julho de 1.994 (Estatuto da Advocacia) que os honorários advocatícios pertencem ao advogado da parte e não à própria parte. Esse dispositivo, além de criar um vínculo obrigacional entre sujeitos que não têm qualquer relação entre si (parte sucumbente e patrono da parte adversa), ainda causa um sério problema para compatibilizá-lo com o art. 21 do Código de Processo Civil, na medida em que cria uma modalidade de compensação entre partes que não são titulares de créditos e débitos entre si. Leitura diferente sobre o tema é a feita por BRUNO VASCONCELOS CARRILHO LOPES, Honorários advocatícios no processo civil, pp. 11-20, que entende que os honorários têm natureza de sanção processual com cunho indenizatório, mas a indenização seria para ressarcir o trabalho realizado pelo advogado e não o gasto da parte em contratá-lo. O raciocínio é muito respeitável, especialmente por ser a única forma racional de explicar o art. 23 Estatuto da Advocacia. Contudo, entendemos que é necessário manter a crítica dirigida ao legislador, porque essa opção força os limites do caráter indenizatório da verba de sucumbência já que, como afirmado, inexiste qualquer relação ou vínculo direto entre a parte sucumbente e o advogado da parte adversa. Ela não contratou os serviços desse profissional e ele não executou qualquer serviço para ela, de modo que não existe razão para obrigá-la a pagar pelos serviços de um profissional que não a auxiliou.

${ }^{387}$ Mencionamos que elas são assemelhadas porque em ambas tem-se uma conduta que a lei pretende reprimir e a previsão de uma conseqüência (sanção) para a sua inobservância. Não pretendemos, todavia, afirmar que sejam equivalentes. A propósito, destacamos novamente as palavras de HELENA ABDO $O$ abuso do processo, p. 115: "Dizer que o ato abusivo difere do ato ilícito não equivale a negar ao ato abusivo a qualidade de fonte de responsabilidade. Em outras palavras, o ato abusivo - independentemente da sua autonomia em relação à teoria da responsabilidade civil - é, sim, fonte de responsabilidade e pode perfeitamente ensejar a reparação de danos”.

${ }^{388}$ V. BRUNELA VICENZI, A boa-fé..., pp. 98 e ss.. A autora, todavia, exclui a responsabilidade pelo pagamento das despesas processuais desse modelo ao entendimento de que ela não constitui uma penalidade, nem uma sanção por ato ilícito, sendo "estranha à noção de abuso de direito". Fundamentado-se nos ensinamentos de JOSSERAND, afirma, então, que essa responsabilidade procede de uma repartição do risco judiciário (p. 102). 


\subsection{Direitos processuais adquiridos e institutos bifrontes}

O último campo que falta analisar para delimitação dos direitos adquiridos é o dos institutos bifrontes ou de natureza processual material.

DINAMARCO, fundamentando-se nos ensinamentos de CHIOVENDA ${ }^{389}$, trouxe para a doutrina do direito processual intertemporal a questão dos institutos bifrontes, afirmando que a disciplina intertemporal dos fenômenos a eles relacionados comportaria um tratamento diferenciado, não sendo aplicável imediatamente ${ }^{390}$.

Já foi dito que esses institutos se situam nas faixas de estrangulamento entre o direito material e o processual. Importa agora compreender o que isso significa e quais os seus reflexos para o direito intertemporal.

Inicialmente deve-se mencionar que os institutos que se encaixam nessa categoria, segundo as lições do mestre paulista são a ação, a competência, a prova, a coisa julgada e a responsabilidade patrimonial. Dizer que eles são institutos de natureza bifronte significa que, embora eles somente apareçam de modo explícito no processo, de algum modo dizem respeito à própria vida dos sujeitos e suas relações entre si e com os bens da vida ${ }^{391}$.

Em função dessa ligação clara com o direito material, as normas processuais que regem esses institutos não podem ter aplicação imediata, devendo-se manter a aplicação da norma em vigor no momento da realização do negócio jurídico material.

Esses ensinamentos foram criticados por FÁBIO TABOSA PESSOA que entendeu haver um "desvio de perspectiva na abordagem inicial

\footnotetext{
${ }^{389}$ Instituições..., vol. I, §4, n. 23.

${ }^{390}$ Instituições..., vol. I, pp. 100-103.

${ }^{391}$ Instituições..., vol. I, p. 44.
} 
dos institutos, que gerando hipóteses paradoxais quanto a situações de direito material que poderiam a eles estar ligadas, motivou solução de tal ordem"392. Após essas observações o autor prosseguiu com a análise pontual de cada um dos casos indicados por DINAMARCO, tendo concordado com as soluções propostas por fundamentos distintos, na maioria das vezes ao entendimento de que o instituto não seria bifronte, mas de natureza substancial ${ }^{393}$.

De nossa parte, preferimos a construção de DINAMARCO, porque não podemos concordar com a natureza substancial de muitos desses institutos, muito menos com a explicação do chamado "direito à administração da justiça", que seria pressuposto ao direito de ação, mas que não se confundiria com esse e teria natureza substancial.

Apesar de preferirmos a explicação que parte da natureza híbrida de alguns desses institutos e da possibilidade de incluí-los no conceito de direitos processuais adquiridos, ressaltamos que não estamos inteiramente de acordo com a extensão conferida por DINAMARCO para esses institutos, especialmente para o da competência que, parece-nos, é instituto de natureza exclusivamente processual.

Antes de analisarmos cada um dos exemplos citados nas lições do Professor das Arcadas, cumpre fazer um esclarecimento adicional sobre esses institutos. Para entender a natureza bifronte e a íntima relação que eles detenham com a situação jurídica de direito material, é importante entendê-los como uma forma de assegurar o pleno gozo e exercício dos direitos materiais, sem a qual a realização prática desses direitos seria colocada em sério risco. Justamente por isso, a constituição dos direitos adquiridos processuais desses institutos bifrontes se dá em momento anterior ao processo, juntamente com a constituição do direito subjetivo a que estão atrelados.

Dito isso, podemos iniciar pela análise da ação como um instituto híbrido e suas conseqüências para o direito intertemporal. Já foi

\footnotetext{
${ }^{392}$ Elementos para uma teoria..., p. 167.

${ }^{393}$ Elementos para uma teoria..., pp. 164-171.
} 
analisado acima o direito de ação e sua proteção dentro do processo. A associação que se deve fazer da ação com o direito material diz respeito ao momento em que esse direito é adquirido e que, portanto, deve ser levado em consideração para a análise das condições da ação.

É ocioso afirmar que a eficácia do direito subjetivo fica severamente comprometida sem a ação que o proteja contra o não cumprimento espontâneo do dever ou da obrigação correspondente por parte do devedor ${ }^{394}$. Justamente por isso, a ação deve ser entendida como um meio de garantir a efetividade do direito subjetivo material. Daí resulta que o legislador não pode criar óbices que impeçam o seu verdadeiro exercício ${ }^{395}$, de modo que, se tais óbices eventualmente vierem a ser criados, não se aplicarão às ações cujos direitos já tenham sido constituídos.

É importante ressalvar, contudo, que somente o direito de ação está garantido, vale dizer, a possibilidade de buscar a solução judicial para a crise de direito material é que não pode ser atingida. O modo como essa possibilidade é conferida às partes pertence ao campo de liberdade do Estado e não é suscetível de aquisição por elas. Invocando novamente exemplo trazido por DINAMARCO, podemos imaginar uma lei que suprima um determinado título executivo. Ela terá eficácia imediata para impedir a propositura de novas ações executivas fundadas nesse título, desde que deixe aberta a via do processo de conhecimento para a solução da crise de inadimplemento ${ }^{396}$.

\footnotetext{
${ }^{394}$ Mencionamos que a eficácia do direito subjetivo fica severamente comprometida porque, de um lado, é possível que haja o adimplemento espontâneo da obrigação e, de outro, existem casos em que, mesmo não havendo mais a tutela jurisdicional para o suposto direito subjetivo, uma vez que haja o cumprimento da obrigação, aquele que o efetuou não poderá reclamar sua repetição, como nos casos de prescrição ou pagamento de dívidas de jogo. Para uma análise mais aprofundada desses exemplos, com posição que critica a possibilidade de configuração de um direito que não seja tutelado pelo Estado, v. MOREIRA ALVES, “Direito subjetivo...”, p. 115.

395 DINAMARCO traz dois bons exemplos dessas situações, quais sejam, a criação de uma impossibilidade jurídica nova, que não poderá suprimir o direito de ação anteriormente constituído, e a obrigatoriedade de um litisconsórcio necessário ativo, que também não poderá afetar as partes que anteriormente poderiam propor a demanda isoladamente. Esse segundo exemplo, fundado no art. 623, inc. II, do Código Civil, que exige a participação de todos os condôminos para os litígios referentes à propriedade, é bastante ilustrativo do modo como a criação de uma dificuldade extrema pode obstar o direito de ação.

${ }^{396}$ Insituições..., vol. I, p. 102. Em sentido contrário, defende LUCAS RISTER DE SOUSA LIMA que o detentor do crédito continuaria podendo fazer uso da via expropriatória (Direito intertemporal..., p. 142).
} 
Com relação à responsabilidade patrimonial, sua identificação como instituto de natureza híbrida tem a dupla conseqüência de permitir sua inclusão no campo dos direitos processuais adquiridos e determinar que o momento de aquisição desse direito coincide com o da obrigação a que ele se refere.

Para que se possa compreender a responsabilidade patrimonial como categoria de direito processual material é necessário pensar que a eficácia da tutela executiva depende da existência de bens do executado que possam ser expropriados e garantir a satisfação do crédito exeqüendo. Assim, quando a lei determina que tais ou quais bens do devedor respondem pela obrigação, isso equivale a uma garantia futura para o credor, que sabe que terá meios de satisfazer o seu crédito judicialmente, caso o devedor não cumpra espontaneamente com a obrigação ${ }^{397}$.

Para o direito intertemporal a responsabilidade patrimonial deve ser entendida como uma garantia de eficácia do direito de ação e, assim, o direito processual adquirido refere-se a essa garantia de eficácia e não a uma eventual disponibilidade do patrimônio do devedor para a satisfação do seu crédito $^{398}$.

397 FÁBIO TABOSA PESSOA, apoiando-se nos ensinamentos de CAIO MARIO, entende que a responsabilidade patrimonial é instituto eminentemente de direito substancial (Elementos para uma teoria..., p. 171) o que permite a compreensão da existência de direito adquirido a ela que não é processual, mas substancial. Em sentido oposto, entende TEORI ZAVASCKI, Comentários ao Código de Processo Civil, vol. 8. pp. 260-261, que: "Acertada, portanto, ao contrário do que afirma certa corrente doutrinária, a preocupação do legislador em disciplinar, em capítulo do Código de Processo, o tema da responsabilidade patrimonial. Trata-se, com efeito, de instituto de natureza processual, cuja invocação e atuação é desencadeada em decorrência da crise que se estabelece pelo não cumprimento espontâneo da obrigação e pela conseqüente necessidade do recurso à tutela do Estado". Em que pese ser possível vislumbrar um caráter processual na responsabilidade patrimonial, achamos necessário ressaltar a existência de um vínculo muito forte entre ela e o direito de crédito a que se refere, de modo a caracterizá-la como instituto de direito processual material. Nesse sentido, BEDAQUE defende a existência no plano substancial de um "direito à higidez patrimonial pertencente aos credores quirografários, menos intenso, mas de natureza idêntica aos direitos reais de garantia" e prossegue "Daí afirmar-se que o 'terreno da responsabilidade patrimonial, ou executiva, constitui zona de estreitíssimo estrangulamento entre o plano substancial e o processual do ordenamento jurídico', podendo ser incluído no campo do denominado direito processual material" (Direito e processo..., pp. 73-74).

${ }^{398}$ Isso porque, o devedor pode livremente dispor de seus bens desde que não frustre os meios executórios. Nesse sentido, v. FREDERICO FONTOURA DA SILVA CAIS, Fraude de execução, pp. 128-130 e pp. 139143. 
Pensemos, por exemplo, na lei que instituiu o bem de família. Se, ao desfazer penhoras anteriormente constituídas que atingissem a moradia do executado, a lei determinasse que fossem oferecidos novos bens, com liquidez de mercado, para permitir o levantamento da penhora realizada, ela não afetaria a garantia de eficácia da ação executiva ${ }^{399}$. Não feriria, assim, direito adquirido do exeqüente, embora fosse retroativa ao atingir uma situação jurídica processual constituída, ou seja, a penhora realizada.

Contudo, ao determinar o cancelamento das execuções pendentes sem qualquer ressalva quanto à necessidade de oferecimento de bem idôneo para permitir que a responsabilidade patrimonial não recaísse sobre o bem de família, e, pior, ao ser aplicada indiscriminadamente para retirar os bens de família do alcance de toda e qualquer responsabilidade patrimonial anteriormente assumida, a lei, com o respaldo da jurisprudência, feriu gravemente direitos adquiridos dos exeqüentes ${ }^{400}$.

Com relação à competência é importante destacar que DINAMARCO fundamenta sua natureza híbrida apenas para delimitar a impossibilidade de criação de tribunais de exceção, bem como para demonstrar que a Constituição torna "irrelevantes as novas competências fixadas ulteriormente, sempre que isso reduza a possibilidade de ampla defesa (Const., art. $5^{\circ}$, inc. $\left.X X X V I I\right){ }^{, 401}$.

Parece-nos, aqui, que não se deve falar em natureza híbrida do instituto da competência, ao menos não para o direito intertemporal. A garantia constitucional contra tribunais de exceção é um desdobramento do direito de

\footnotetext{
399 Tratando da isenção da responsabilidade patrimonial conferida ao bem de família, assim se posicionou BEDAQUE, Direito e processo..., p. 74: "Por isso, a isenção legal somente deve prevalecer caso não se verifique o estado de insolvência, devendo o executado tomar as providências necessárias à substituição do bem. Se inexistir outro passível de penhora, não pode ele se valer do benefício, sob pena de lesão a um interesse legítimo, a quem a ordem jurídica oferece proteção, inclusive em sede constitucional (CF, art. $5^{\circ}$, XXXVI)".

400 Justamente por isso essa lei foi alvo de duras críticas por parte da doutrina. V. DINAMARCO, Instituições, vol. I, p. 103; BEDAQUE, Direito e processo..., pp. 72-75; LUCAS RISTER, Direito intertemporal no processo civil, p. 150 e FÁBIO TABOSA PESSOA, Elementos para uma teoria..., p. 136.

${ }^{401}$ Instituições..., vol. I, p. 102.
} 
defesa e não deve ser analisada sob a ótica da competência ${ }^{402}$. Essa continua sendo matéria de organização judiciária e somente gera direitos processuais adquiridos quando sua instituição se dá para defesa de interesses privados e torna-se alvo de uma convenção entre as partes, conforme demonstrado nos tópicos anteriores ${ }^{403}$.

Justificando a inserção da coisa julgada dentre os institutos bifrontes, DINAMARCO observou que o aumento de um prazo recursal após o trânsito em julgado da sentença não pode atingir a coisa julgada já formada, e mesmo o aumento de prazo para propô-la não pode afetar os processos em que esse prazo já tenha sido extinto.

Concordamos com os exemplos citados, mas entendemos que a inclusão da coisa julgada entre os institutos bifrontes merece ressalva. No plano do direito processual material a coisa julgada agrega uma qualidade ao direito subjetivo da parte. Esse direito, passa a ser um direito afirmado por sentença judicial transitada em julgado, o que significa que não poderá mais ser colocado em discussão em processo judicial envolvendo as mesmas partes ${ }^{404}$.

\footnotetext{
${ }^{402}$ FÁBIO TABOSA PESSOA, Elementos para uma teoria..., p. 168, também afasta a caracterização da competência como instituto bifronte, ao entendimento de que o problema de direito intertemporal aventado por DINAMARCO é solucionado pela observância das garantias do juiz natural e do contraditório que têm sede constitucional, não havendo espaço para um problema de direito intertemporal relativo à matéria.

${ }^{403}$ DINAMARCO não discorda desse posicionamento, tanto que, logo após fazer a observação acima destacada, remete o leitor de sua obra aos tópicos 80-81, onde se lê: "Novas competências, estabelecidas depois de ocorridos os fatos que constituem fundamento de uma pretensão a ser deduzida em juízo, impõemse ao processo civil que se instaurar em busca da satisfação desta. 'Determina-se a competência no momento em que a ação é proposta', não antes (CPC, art. 87). Mesmo quando já instaurado o processo, a competência passará para outro órgão judiciário nas hipóteses de extinção do órgão prevento ou de superveniência de novas normas que lhe alterem a competência absoluta” (Instituições..., vol. I, p. 203).

${ }^{404}$ Os limites subjetivos da coisa julgada estendem-se, como regra, somente às partes do processo. Contudo, como bem observa CRUZ E TUCCI, Limites subjetivos da eficácia da sentença e da coisa julgada civil, pp. 40-41: "a interdependência das relações negociais e a complexidade do comércio jurídico acabam rompendo as fronteiras do denominado princípio da relatividade da coisa julgada $e$, com isso, torna-se inexorável a projeção, ainda que por via reflexa, dos efeitos da decisão e, às vezes, em caráter excepcional, da própria expansão da autoridade da coisa julgada a terceiros". Todavia, como bem anota o Professor paulista "nos quadrantes de uma ciência processual dominada por regramentos éticos e políticos, de tendência marcadamente democrática, repugna a idéia de que um sujeito de direitos, sem que lhe seja assegurado 'o contraditório e ampla defesa, com os meios e recursos a ela inerentes', para que possa, na condição de parte, apresentar suas próprias razões, venha a ser privado de seus bens por força de decisão judicial transitada em julgado. Quando nada, haveria inarredável afronta à letra dos incisos LIV e LV do art. $5^{\circ}$ da Constituição Federal” (pp. 42).
} 
Abstraindo-se do direito material em litígio, pode-se entender que a coisa julgada faz nascer para o vencedor um direito subjetivo de não ter que se sujeitar a uma nova demanda envolvendo as mesmas partes, a mesma causa de pedir e o mesmo pedido ${ }^{405}$.

É claro que a coisa julgada não impede o perdedor de intentar uma nova ação idêntica contra o vencedor da demanda. O que ela impede é que o juiz conheça os fundamentos da demanda e analise o seu mérito (CPC, art. 267, inc. V). Assim, do ponto de vista processual, pode-se entender a coisa julgada como um direito processual adquirido relacionado com o direito de defesa, mas potencialmente diferenciado, porque permite ao réu não somente exigir uma resposta do juiz que analise a sua defesa, mas que a acolha.

Feitas essas colocações, parece-nos possível explicar nossa concordância com os exemplos acima descritos. A coisa julgada é um direito processual adquirido e, uma vez que passe a integrar o "patrimônio" de seu titular não pode ser excluída por lei posterior. Justamente por isso, lei que venha a aumentar o prazo recursal não pode atingir a coisa julgada já formada. Caso contrário, estaríamos diante de uma hipótese em que a coisa julgada seria desfeita. Raciocínio parecido aplica-se ao segundo exemplo. A coisa julgada não é um direito ilimitado. Pode a sentença ser rescindida dentro do prazo de dois anos, em casos excepcionais. Contudo, passados esses dois anos, ela se torna quase ilimitada ${ }^{406}$ e confere à sentença uma qualidade ainda maior de imutabilidade. Poder-se-ia comparar o transcurso desse prazo ao próprio transcurso do prazo recursal e afirmar que depois dele nasce uma "nova coisa julgada", mais forte do que a primeira. A partir daí fica fácil compreender que o

\footnotetext{
${ }^{405}$ Incluímos os três eadem porque do ponto de vista do réu que se sagre vencedor, a proteção somente impedirá que ele tenha que se sujeitar a uma demanda idêntica, já que a eficácia preclusiva da coisa julgada não atinge o direito do autor de propor uma nova demanda, com pedido idêntico ao anterior mas fundada em outra causa de pedir. Ou, de propor uma demanda com pedido diverso fundada na mesma causa de pedir.

${ }^{406}$ Dissemos "quase” ilimitada, porque a partir da sistemática adotada nos artigos 475-L, § $1^{\circ}$, e 741, pár. único do CPC é possível visualizar no ordenamento casos em que sentenças transitadas em julgado perderão ser 'rescindidas' mesmo após o transcurso de prazo para ação rescisória. Para uma crítica desses dispositivos, com fortes argumentos para demonstrar que são inconstitucionais (v. YARSHELL, Ação rescisória, pp. 254259). Além desses casos, muitos processualistas vêm defendendo a relatividade da coisa julgada, que, em determinadas hipóteses excepcionais, poderia ser desconstituída mesmo após o transcurso do prazo para propositura da ação rescisória (v. DINAMARCO, "Relativizar a coisa julgada material, passim, e EDUARDO TALAMINI, A coisa julgada e sua revisão, pp. 376 e ss.. Para ponto de vista contrário, v. por todos BARBOSA MOREIRA, “Considerações sobre a chamada 'relativização' da coisa julgada material”).
} 
direito advindo com a coisa julgada para o vencedor novamente é criado a partir desse prazo e ele não poderá mais se sujeitar a uma ação rescisória.

Mas, esclarecidas essas hipóteses, deve-se ressaltar que o regime da coisa julgada não é passível de aquisição pelas partes, razão pela qual, qualquer alteração do prazo para propositura da ação rescisória enquanto esse ainda estiver fluindo poderá ser aplicável ${ }^{407}$, desde que não implique em imediata supressão do direito de ação para o perdedor - o que poderia acontecer se a redução do prazo não garantisse a ele a propositura da demanda no novo prazo estabelecido pela lei.

Por outro lado, a supressão de uma hipótese para propositura da ação rescisória, ou a criação de uma nova, não poderá ser aplicada aos processos já transitados em julgado, em função das projeções que elas trazem para o direito de ação e de defesa. O primeiro caso equivale à criação de uma impossibilidade jurídica nova e, conforme já exposto, não pode afetar os direitos de ação anteriormente constituídos ${ }^{408}$. O segundo, acarretaria uma perda direta para o direito criado para o vencedor com a coisa julgada, na medida em que esse direito lhe garante que não se submeta a uma ação rescisória fora das hipóteses previstas na lei no momento do trânsito em julgado. Raciocínio oposto conduziria à possibilidade de eliminação do direito em etapas.

Deixamos propositalmente por último a análise dos ônus e meios de prova, porque esse é o campo que suscita maiores dúvidas no direito intertemporal.

Pode-se dividir a questão em três correntes principais: (i) a que afirma que a natureza jurídica da prova é de direito material; (ii) a que a

\footnotetext{
${ }^{407}$ Essa não é a orientação do direito italiano, segundo demonstra SERGIO LA CHINA, Manuale di diritto processuale civile, vol. I, p. 35, que confere um regime bastante rígido para a proteção intertemporal da coisa julgada, impedindo que qualquer alteração no regime de sua impugnação possa surtir efeito para atacar a coisa julgada já formada, inclusive o alongamento de prazo ainda em curso.

${ }^{408}$ Isso porque, se o direito de ação nasce com a constituição da relação jurídica material à qual ele se refere, o direito de propositura da ação rescisória nasce com o trânsito em julgado da sentença. Esse é o marco temporal que deve ser levado em consideração para análise dos requisitos viabilizadores da propositura dessa ação.
} 
associa ao direito processual e, (iii) a intermediária, que a entende como instituto de natureza bifronte 409 .

A admissão de que a prova seja um instituto de natureza processual material implica na consciência tanto de que ela será desenvolvida no processo e para os fins desse, como também de que a impossibilidade de provar o direito pode acarretar a sua perda, em função do enfraquecimento da posição da parte dentro do processo.

Para o direito intertemporal, o problema se coloca em saber se as leis relativas às provas devem ser aquelas do momento em que a relação jurídica foi constituída ou, ao contrário, se devem ser as que estiverem em vigor durante o curso da demanda.

Muitos dos defensores da primeira posição afirmam que é necessário respeitar a vontade das partes no momento da realização do negócio jurídico. Assim, por exemplo, "quem contratou em um momento em que a prova testemunhal era permitida, teve em mira essa permissão e, se assim não fosse, teria pensado em munir-se de um documento, ou teria deixado de contratar ${ }^{\prime 410}$.

Essa premissa, contudo, está repleta de equívocos que comprometem sua validade. Primeiramente, não se pode realmente afirmar que, ao celebrar um contrato as partes analisam as regras vigentes sobre provas e, a partir daí, optam pela forma de comprovação dos fatos que envolvem o negócio. Esse raciocínio certamente não se aplica para a maioria dos negócios realizados entre particulares, que sequer sabem dizer quais os meios de prova admitidos, muito menos quais as regras para divisão dos seus ônus. Mesmo nos casos em que as partes são orientadas por advogados e tomam cautelas para comprovação dos fatos que envolvem o negócio, elas não se preocupam com o processo futuro, mas tão somente em provar o seu direito. Isso significa que as partes não levam em consideração a força de cada prova e o modo como o juiz as avaliará.

\footnotetext{
${ }^{409}$ Para uma ampla análise das principais correntes a respeito do tema, v. MARICÍ GIANNICO, A prova no Código Civil - natureza jurídica, pp. 158 e ss..

410 O exemplo é tirado do ensaio de CHIOVENDA, "La natura processuale delle norme sulla prova e l’efficacia delle legge processuale nel tempo” (p. 248).
} 
Consideram apenas que devem se munir de elementos para eventualmente comprovar a existência dos seus direitos ${ }^{411}$.

Dessas considerações iniciais já é possível fazer um primeiro corte, para demonstrar que todo o incremento probatório que sobrevier à relação jurídica de direito material deverá ser utilizado no processo, porquanto a associação da prova com o direito material deve ser entendida como um meio de garantir que a parte não perca o seu direito em função de uma impossibilidade de comprovar algum fato, não como um meio de vencer a demanda mesmo sem ter razão ${ }^{412}$. Veja-se assim, que se ao realizar um determinado negócio jurídico era vedada a utilização de prova testemunhal para comprová-lo, lei que altere essa sistemática e passe a permitir tal prova será imediatamente aplicável aos processos pendentes, porque a parte não terá direito à vedação de uma prova ${ }^{413}$.

Por outro lado, dois elementos devem ser levados em consideração no momento de apreciar se a parte tem direito a uma determinada prova: (i) o impacto que a supressão dessa prova pode ocasionar para a possibilidade da parte comprovar o seu direito; e (ii) se era razoável ao tempo da realização do negócio que a parte não adotasse outras cautelas para comprovar os fatos que compõem o negócio jurídico.

Assim, suponha-se que uma lei venha a proibir determinado meio de prova, o qual tinha sido utilizado pelas partes para certificação do negócio jurídico por elas realizado. Se esse negócio puder ser comprovado por outra prova, proveniente de um meio diferente, a parte não poderá exigir sua utilização no processo.

Além do mais, é necessário examinar a praxe do negócio jurídico para saber se a parte foi suficientemente diligente ao pretender comprovar

\footnotetext{
${ }^{411}$ CHIOVENDA, “La natura processuale...”, pp. 248-249.

412 "La questione sta appunto ciò; se le parti che pensano alle norme concernenti la prova debbano considerarle come norme immutevoli del negozio che compiono, o come l'espressione di condizioni sociali estrinseche al negozio e soggette a mutare" (CHIOVENDA, "La natura processuale..., p. 250).

${ }^{413}$ Isso porque,"quanto mais eficazes forem os meios de prova e quanto maior for a sua capacidade de fornecer subsídios seguros ao investigador dos fatos, menores as chances de erro ou injustiça da decisão" (MARICÍ GIANNICO, A prova..., p. 109).
} 
os fatos que compõem esse negócio apenas por uma única prova, cuja utilização passou a ser proibida. A questão fica mais fácil de ser examinada se houver uma lei específica regulamentando determinado negócio jurídico e afirmando a possibilidade de comprovação de determinados fatos por um meio específico de prova $^{414}$.

As duas hipóteses podem ser parecidas, mas não se identificam. O momento de aferição da primeira é durante a pendência da demanda, já a segunda refere-se ao tempo em que foi realizado o negócio jurídico.

Presentes esses dois requisitos a parte será detentora do direito de utilizar a prova que passou a ser vedada ${ }^{415}$, porque negá-lo implicaria em inviabilizar a efetivação do direito em juízo ${ }^{416}$.

Tudo o quanto foi dito sobre a matéria probatória refere-se a sua compreensão como instituto bifronte e ao direito pré-processual de utilizá-la. É importante frisar, ainda, que a prova deve ser entendida como um componente

\footnotetext{
${ }^{414}$ A partir da análise da existência de leis particulares sobre prova, CHIOVENDA concluiu seu estudo afirmando que, quanto às normas probatórias gerais, não pode haver direito adquirido e a aplicação da lei é imediata. Porque ao ditá-las o legislador busca regulamentar a atividade intelectiva do juiz a fim de permitir que forme o seu convencimento da melhor maneira possível. Já quanto às normas probatórias particulares, elas se inserem dentro da regulamentação de uma determinada relação jurídica, e o legislador ao ditá-las, tem em vista essa relação, buscando uma forma adequada para discipliná-la e tutelá-la. Por esse motivo, as normas particulares sobre prova não podem ser aplicadas para fatos constituídos antes do seu advento ("la natura processuale..., pp. 255-257). As lições do mestre italiano são extremamente úteis para a compreensão do modo como um regramento especial sobre prova pode influenciar nas decisões tomadas pelas partes no momento de constituição do negócio jurídico. Discordamos, contudo, de suas conclusões por dois aspectos fundamentais. Primeiramente entendemos que, ainda que constantes de diplomas que tratem de determinadas relações jurídicas específicas, as normas sobre provas continuam a se dirigir para o juiz, pois sua principal utilidade será sempre a de fornecer elementos para solução de uma determinada crise. Por outro lado, entendemos que a solução adotada vai além do que propomos, pois não só permite a utilização de meios de prova que tenham sido proibidos por lei posterior, como impede a utilização de novos meios que passem a ser aceitos.

${ }^{415}$ Restará, ainda, um problema. Se essa prova não tiver sido produzida no momento da realização do negócio, o direito da parte de utilizá-la terá que ser sopesado com os valores que levaram à sua proibição, caso esses tenham sede constitucional. V., a propósito, nota inserida no item 5.2.1, supra.

${ }^{416}$ É nesse sentido bastante limitado que devem ser entendidas as palavras de DINAMARCO ao lecionar que a privação das partes "dos meios antes postos à sua disposição para a obtenção da tutela jurisdicional (provas, bens), teria o efeito de suprimir direitos adquiridos” (Instituições..., vol. I, p. 101).
} 
do direito de ação e de defesa ${ }^{417}$, o que implica em dizer que um procedimento que impeça ou dificulte sobremaneira o direito à prova será inconstitucional por ferir uma garantia do direito a um processo justo e équo. A questão, todavia, resume-se à análise de constitucionalidade da lei e não traz maiores conseqüências para o direito intertemporal.

Dentro do processo, a parte tem direito a um procedimento que Ihe assegure possibilidades plenas de comprovação do seu direito. Uma vez que cumpra o ônus de requerer sua produção, terá o direito de não sofrer as conseqüências de um eventual indeferimento da prova por parte do juiz. Isso significa que, se a prova foi regularmente requerida e o juiz a indeferiu por entendê-la desnecessária, protelatória ou inútil, ele não poderá basear sua decisão na ausência de comprovação de um fato que seria objeto dessa prova ${ }^{418}$. Esses direitos são desdobramentos do direito de ação e de defesa e é nisso que se resume o direito à prova dentro do processo. A parte não tem direito a uma determinada prova, porque a prova pertence ao juiz, que detém poderes para deferir ou indeferir sua produção, de acordo com a sua necessidade e pertinência $^{419}$.

\subsection{Momentos de aquisição dos direitos processuais adquiridos}

Achando-se traçados os limites dos direitos processuais adquiridos, podemos agora analisar o momento em que esses direitos são adquiridos.

Com relação aos institutos bifrontes tem-se que a aquisição do direito processual ocorre conjuntamente com a do direito material. É nisso que

\footnotetext{
417 V. MARICÍ GIANNICO, A prova..., pp. 107-113; BEDAQUE, “Garantia da amplitude de produção probatória”, pp. 168-170 e CORRADO-FERRI-TARUFFO, Lezioni sul processo civile, p. 609.

${ }^{418}$ Por essa razão é que BEDAQUE faz o seguinte alerta: "as regras que permitem ao juiz dispensar prova desnecessária devem ser aplicadas com extremo cuidado, pois podem representar violação a um dos componentes do contraditório e da ampla defesa” ("Garantia da amplitude..., p. 170).

419 Nem mesmo se houver deferido uma prova o juiz ficará vinculado a produzi-la. Se entender posteriormente que essa prova é impertinente ou desnecessária poderá deixar de realizá-la. Em sentido contrário, v. MANOEL CAETANO FERREIRA FILHO, A preclusão no direito processual civil, p. 92.
} 
consiste a diferenciação dos direitos processuais adquiridos advindos desses institutos dos demais, que nascem durante a pendência da demanda.

Quando pensamos nos direitos adquiridos no curso do processo, devemos diferenciar os poderes dirigidos ao juiz, daqueles que dizem respeito a um relacionamento travado diretamente entre as partes.

Com relação aos primeiros, considera-se adquirido o direito a partir do momento em que nasce para a parte a faculdade de praticar determinado ato que Ihe gerará o poder de exigir uma resposta do juiz ${ }^{420}$. É importante lembrar que a noção de direito adquirido tem em sua base o fato de ser um direito exercitável e não necessariamente exercido, o que demonstra que, desde o surgimento da possibilidade de praticar o ato é que ele é entendido como adquirido.

Quando pensamos, por outro lado, nos direitos advindos das relações jurídicas travadas diretamente entre as partes, o momento de aquisição do direito equivale ao da prática do ato que o originou ou da decisão judicial que o reconheceu. Assim, nos negócios jurídicos processuais esse momento equivale à celebração do acordo $^{421}$. Com relação aos direitos de reparação de danos processuais, nascem com a decisão judicial que os reconhece ${ }^{422}$.

Por fim, deve-se fazer uma observação com relação ao direito de ação e os direitos deles decorrentes no curso do processo. Esse direito

\footnotetext{
${ }^{420}$ Quando se pensa no momento em que essa faculdade nasce, deve-se considerar o momento em que o ato já pode ser praticado. Assim, não é a publicação no diário oficial que assegura o direito ao recurso, mas a integração do ato ao processo, conforme esclarece DINAMARCO, “Tempestividade dos recursos”, pp. 1213.

${ }^{421}$ Mesmo na hipótese de desistência conjunta da ação que é sujeita a homologação, porque nesses casos a homologação funciona apenas como uma fiscalização da regularidade do ato. Se o acordo foi celebrado de maneira regular (por partes capazes de desistir da ação) a homologação funciona apenas como um termo e o direito é adquirido desde a celebração do acordo. A propósito da função fiscalizadora do juiz, estendendo-a, inclusive para os demais atos que não estão inseridos no parágrafo único do art. 158, v. MONIZ DE ARAGÃO, Comentários ao código de processo civil, vol. II, p. 30.

${ }^{422}$ É importante lembrar que nos casos de cumprimento antecipado de decisões judiciais o direito à reparação do dano somente se inicia a partir do momento em que ocorre o reconhecimento judicial definitivo de que esse cumprimento foi indevido (v. PAULO AFONSO GARRIDO DE PAULA, Código de processo civil interpretado, p. 2.326), mas, como a reparação do dano deverá ser integral, sua apuração deverá ser feita a partir do momento em que foi efetivada a decisão que o ocasionou.
} 
é, desde o princípio, condicionado pelo modo de atuação das partes ${ }^{423}$. Assim, não basta que o autor preencha, no início da demanda, os requisitos necessários para que sua petição inicial seja analisada no mérito. Para que esse seja julgado é necessário que as partes cumpram uma série de atos, cada um com requisitos próprios, que podem ser alterados no curso da demanda ${ }^{424}$. Os requisitos de cada ato devem ser analisados no momento em que são praticados, para o fim de se averiguar se são aptos a gerar o poder para a parte de exigir o comportamento correlato do juiz ${ }^{425}$.

\section{Capítulo VIII - Poderes do juiz e direito processual civil intertemporal}

\subsection{Considerações iniciais}

Desde que as legislações passaram a tratar diretamente do direito intertemporal os estudiosos do tema entenderam que se a proteção contra a retroatividade da lei (ou aos direitos adquiridos) estiver inserida na Constituição ela se dirige tanto para o juiz como para o legislador. Caso contrário, somente para o juiz ${ }^{426}$.

\footnotetext{
${ }^{423}$ Mencionamos ambos, porque pode acontecer de que, em função das alegações do réu ou do resultado de uma determinada prova, o autor perca o interesse no julgamento de mérito da demanda. Nesse caso, também incumbirá ao réu, se for do seu interesse, zelar pelo bom andamento da marcha processual de modo a permitir que ela atinja o seu fim.

${ }^{424}$ Pedimos licença para mais uma vez citar as sempre precisas lições de DINAMARCO, Instituições..., vol. II, p. 292: "A a ação não é, em si mesma e desde logo, direito à sentença de mérito ou poder de exigi-lo. $O$ autor só terá o poder de exigir o provimento de mérito e o juiz o dever de emiti-lo, quando chegar o momento adequado para tanto, já tendo sido realizados todos os atos do procedimento e satisfeitos todos os requisitos indispensáveis I (os pressupostos de admissibilidade do provimento de mérito)”.

${ }^{425}$ Isso não significa, contudo, que a parte tenha direito adquirido à manutenção daqueles requisitos para o ato que foi praticado. O poder da parte refere-se à resposta do juiz. Se a lei criar novos requisitos para o ato e ditar sua aplicação àqueles que se encontram pendentes de solução, desde que seja dada oportunidade para a parte cumprir com esses requisitos não haverá ofensa a direito adquirido, embora a lei, nesse caso, tenha aplicação retroativa.

${ }^{426}$ REYNALDO PORCHAT, Da retroactividade das leis civis, pp. 41-44; BENTO DE FARIA, Aplicação e retroatividade da lei, p. 23; ROUBIER, Le droit transitoire, pp. 222-223; AUBRY e RAU, Cours de droit civil français d'aprés la méthode de zacharie, tome 1er, pp. 99-100.
} 
Isso significa que, em qualquer das hipóteses, não seria permitido ao juiz controlar a eficácia temporal de uma norma. Diante de um problema prático de direito intertemporal caberia a ele tão somente aplicar os princípios e regras constantes do ordenamento para essa solução ${ }^{427}$.

O fundamento mais comum para esse posicionamento sempre foi o princípio da separação dos poderes. O juiz era entendido como la bouche de la loi, sendo sua função exclusiva a de solucionar os casos concretos declarando o direito vigente, função que deveria ser cumprida a partir dos mecanismos colocados pelo ordenamento à disposição, o direito posto ${ }^{428}$.

Além dessa limitação "natural" dos poderes do juiz em matéria de direito intertemporal, havia o temor de conferir maiores poderes para os magistrados, porque isso propiciaria o arbítrio e geraria insegurança para a sociedade. Juiz participativo, ademais, era costumeiramente entendido como juiz parcial, sem neutralidade ${ }^{429}$.

Por esses motivos, e especialmente pelo fato da análise do direito intertemporal ter sido privilegiadamente estudada a partir das relações jurídicas de direito material, o estudo dos poderes do juiz em matéria de direito intertemporal foi relegado para um segundo plano pela doutrina, que concentrou seus esforços na compreensão dos institutos da disciplina e na forma como eles estão inseridos no sistema ${ }^{430}$.

As especificidades do direito processual civil - ramo no qual existem inúmeras normas que regulam situações jurídicas sem gerar direitos adquiridos para os sujeitos interessados na atividade jurisdicional e em que se

\footnotetext{
${ }^{427}$ ROUBIER, Le droit transitoire, p. 225.

${ }^{428}$ LAURENT, Supplemento al diritto civile, vol. 1, p. 22.

${ }^{429}$ Para análise desse temor da doutrina com relação aos poderes do juiz na colheita de prova, v. BEDAQUE, Poderes instrutórios do juiz, pp. 78-79. Essas ressalvas também se dirigem - até com maior intensidade - no que diz respeito à concessão de poderes ao juiz para flexibilização do procedimento, conforme demonstra FERNANDO GAJARDONI, pp. 93 e ss..

${ }^{430}$ Mesmo quando ROUBIER admitiu que caberia ao intérprete a missão de identificar os casos de "sobrevivência da lei antiga", nota-se no seu pensamento que as soluções devem ser dadas em abstrato, para reger de maneira genérica todas as situações pendentes no momento de entrada em vigor da lei. A função do intérprete, nesse caso, será a de identificar a "vontade" do legislador e aplicá-la aos casos concretos (Le droit transitoire, pp. 180-181 e pp. 351-353).
} 
estabelece uma relação jurídica própria, com caráter instrumental à relação de direito material - abrem espaço para que se verifique se o juiz detém poderes para controlar a eficácia temporal da norma processual.

\subsection{Poderes do juiz e 'otimização' do sistema de direito processual intertemporal}

Ao analisarmos os diferentes sistemas de direito processual intertemporal concluímos que nenhum deles pode ser considerado 'ótimo'. Cada um tem vantagens e desvantagens que ora privilegiam a 'segurança' ora 0 'avanço' advindo com a suposta melhoria da legislação, mas, mesmo em um sistema que busque privilegiar um ou outro desses valores, a rígida aplicação de seus postulados pode dificultar que se atinjam os objetivos propostos.

Pedimos licença para retomar a explicação de que nem sempre a aplicação de uma lei nova a um processo pendente poderá conferir-lhe maior efetividade, o que também se aplica quanto à presunção de que a aplicação imediata de uma lei poderá causar insegurança ou descoordenação de atos processuais.

É perfeitamente possível imaginar exemplos de leis cuja aplicação imediata a um processo pendente ocasione sérios prejuízos para a melhor solução da demanda. Pensemos em um processo que teve toda a sua fase instrutória realizada perante um juízo da Justiça Estadual. Suponhamos que se trate de um conflito com fatos bastante complexos que foram todos comprovados pela tomada de inúmeros depoimentos orais. Para deixar a questão um pouco mais complexa, devemos considerar que uma das principais testemunhas tenha falecido pouco tempo depois de prestar seu depoimento. Enfim, imaginemos que o processo já esteja em fase de ser sentenciado quando sobrevém uma Emenda à Constituição alterando a competência para julgamento da demanda, deslocando-a para a Justiça do Trabalho. 
Não se nega que essa norma tenha a propensão de trazer avanços para o exercício da jurisdição, já que o Estado reorganizou a distribuição das competências entre os seus juízes a fim de permitir maior eficiência no desempenho dessa atividade. Ocorre que, para esse caso específico, a aplicação imediata da lei ou bem ocasionará prejuízo para o princípio da identidade física do juiz $^{431}$, caso o novo julgador entenda por aproveitar os atos já realizados ${ }^{432}$, ou gerará um atraso na solução da demanda, que, a depender do número de testemunhas ouvidas, da dificuldade para encontrá-las e da disponibilidade de pauta do novo magistrado, pode ser muito relevante.

Em virtude dessa realidade concluímos que um sistema otimizado de direito intertemporal deverá partir da consciência das deficiências de cada um dos modelos previstos pela doutrina, criando mecanismos para superálas.

Dentre as técnicas imagináveis para esse fim está a concessão de poderes para o juiz, possibilitando-Ihe, em determinados casos, controlar a eficácia temporal da lei nova.

\footnotetext{
${ }^{431}$ Conforme demonstrou CHIOVENDA, Principii... , pp. 680 e ss., esse é um princípio de fundamental importância para a busca da verdade no processo, por permitir ao juiz que tome contato com impressões que não serão posteriormente reduzidas no termo de audiência.

${ }^{432}$ Parece possível afirmar que nosso legislador dá importância secundária a esse princípio, tanto que confere devolutividade plena ao recurso de apelação, permitindo que novos juízes, que não tomaram contato com as testemunhas, julguem novamente os fatos que compõem a demanda. Todavia, não podemos nos esquecer, que na apelação desenvolve-se um juízo de revisão em que se busca "aproveitar aquilo que foi feito pelo juiz de primeiro grau e valorar os resultados já obtidos" (RICARDO DE CARVALHO APRIGLIANO, A apelação e seus efeitos, pp. 2-3) e no exemplo que citamos o afastamento do princípio se daria logo em primeiro grau. Não ignoramos que, em tese, o novo juiz deveria refazer as audiências (que fossem possíveis) a teor do disposto no art. 132 do CPC, mas, como o próprio legislador tratou de relativizar esse princípio possibilitando a outro juiz julgar a demanda nos casos em que o juiz que realizou a audiência estiver convocado, licenciado, afastado por qualquer motivo, promovido ou aposentado, sem a necessidade de repetição dos atos, não seria de se espantar que, para preservar a tempestividade da tutela jurisdicional hoje elevada a garantia constitucional do processo civil (CF, art. 5º inc. LXXVIII) se admitisse como válida a opção pela não repetição dos atos. Mas, ainda que assim não fosse, isso não infirma o exemplo citado, porque ao menos uma testemunha não poderia ser ouvida novamente e ainda haveria prejuízo à tempestividade da tutela jurisdicional em função da necessidade de repetição das audiências.
} 


\subsection{Fundamentos para a concessão de poderes ao juiz no controle da eficácia temporal das leis}

Se em tempos não muito remotos os processualistas precisavam se desdobrar para justificar a concessão de poderes para o julgador $^{433}$, hoje é possível afirmar que já existe uma certa conscientização de que juiz participativo não é sinônimo de juiz autoritário ou imparcial. Não só a doutrina ${ }^{434}$, como a lei o reconhece, tanto que o juiz brasileiro é dotado de amplos poderes de direção e instrução no processo.

O incremento dos poderes do juiz, entretanto, ainda encontra na lei um obstáculo para sua efetiva compreensão. Diz-se, e não sem certa razão, que os poderes do juiz vão até o ponto em que a lei os limita. Sendo função do legislativo a de criar leis, não seria dado ao juiz deixar de aplicá-las ${ }^{435}$.

Essa afirmativa, tratando-se de leis processuais, deve ser entendida com certa reserva.

\footnotetext{
${ }^{433}$ Veja-se, assim, que quando BEDAQUE defendeu a existência de poderes instrutórios para o juiz a tese causava impacto na doutrina tradicional, o que demandou grande esforço persuasivo do autor para que ela se sagrasse vencedora. Hoje, a naturalidade com que esses poderes são reconhecidos é muito maior, o que se reflete numa farta jurisprudência que os admite (v. a propósito NEGRÃO-GOUVÊA-BONDIOLI, Código de processo civil..., nota $2 \mathrm{a}$ ao art. 130 do CPC, p. 273).

${ }^{434}$ De acordo com JOSÉ CARLOS PUOLI, Os poderes do juiz e as reformas da lei processual civil brasileira, p. 54: "se por um lado é certo que a tendência para incremento dos poderes do juiz não pode ser definida como um processo novo de restauração de nossa ciência, por outro pode-se afirmar, sem medo, que ela agora tomou novo rumo e uma mais alta relevância, na medida em que, seja por intermédio do estudo da doutrina que vem sendo produzida neste final de século, seja pelo exame das alterações legislativas recentemente introduzidas em nosso sistema legal, tudo tem colocado o aumento dos poderes do juiz em lugar de destaque entre as várias propostas de alternativas para obtenção dos resultados queridos pelo sistema instrumental do processo". Para uma visão aprofundada do panorama dos poderes do juiz na nossa legislação, v. SIDNEI AMENDOEIRA JÚNIOR, Poderes do juiz e tutela jurisdicional - o aumento dos poderes do juiz como forma de obtenção da tutela jurisdicional efetiva, justa e tempestiva, pp. 116 e ss..

${ }^{435}$ Essa era a forma rígida com que a tripartição dos poderes era entendida pela doutrina da europa continental ao final do século XIX, época em que não se admitia que o juiz deixasse de aplicar a lei, mesmo se ela fosse inconstitucional (v. LAURENT, Principes de droit civil français, vol. I, pp. 66-68). Analisando com profundidade as causas que conduziram a um aumento de poderes do juiz com relação à atividade “criativa” do direito, demonstra CAPPELLETTI, Juízes legisladores?, pp. 43 e ss., esp. p. 53, que enquanto se aplicava rigidamente o princípio da separação dos poderes, tanto o legislador quanto o executivo exerciam a sua parcela sem qualquer controle. $\mathrm{O}$ avanço de poderes do juiz sobre áreas que eram entendidas como reservadas ao legislativo nasceu, assim, como uma forma de controle dessa atividade.
} 
Primeiramente, é preciso deixar registrado não se está aqui a defender um processo anárquico, sem limites para a atuação judicial, em que o juiz decide ao seu livre alvedrio quando irá aplicar uma lei e quando não ${ }^{436}$. Ninguém discorda que o processo precisa de parâmetros seguros que confiram organização e previsibilidade para atuação dos seus sujeitos até a outorga da tutela jurisdicional final. Tais parâmetros são fornecidos pela lei e, para que sejam seguros, precisam ser observados por todos ${ }^{437}$.

Não é menos verdade, por outro lado, que a letra fria da lei muitas vezes distancia o julgador de uma solução justa e célere para o caso concreto. A aplicação da lei processual, destarte, deverá ser feita em consonância com os princípios que orientam essa ciência ${ }^{438}$ o que, muitas vezes, pode levar o julgador a afastar a aplicação de uma lei processual no caso concreto ${ }^{439}$.

\footnotetext{
${ }^{436}$ Conforme demonstra VICENTE MIRANDA, Poderes do juiz no processo civil brasileiro, pp. 80-82, existiram três correntes distintas que pregaram a absoluta liberdade do juiz para julgar contra legem, (i) a da jurisprudência sentimental, adotada pelo juiz MAGNAUD que, ao final do século XIX e início do século XX, sentenciava seus processos guiado exclusivamente pelo seu sentimento, sem preocupação com os textos legais; (ii) a corrente do direito livre, pregada por KANOROWICZ e que consistia na permissão ao juiz de julgar contra a lei, nos casos em que essa aplicação fosse resultar em injustiça; e (iii) a corrente do juiz natural, que autorizava o juiz a deixar de aplicar leis injustas. Tais leis seriam as que ferissem a lei natural e a lei divina. Nenhuma dessas teorias prevaleceu, porque todas conferiam poderes extremamente amplos e genéricos para o juiz afastar a aplicação da lei e acabavam por colocá-lo acima da lei.

${ }^{437}$ Ensina DINAMARCO, Instituições..., vol. I, p. 110, que: “A observância das normas sobre procedimento é penhor de idoneidade no exercício da jurisdição e ao juiz não é lícito omitir atos essenciais ou praticá-los por forma diferente da ditada na lei, a dano dos litigantes".

${ }^{438}$ Em sentido contrário, v. JJ. CALMON DE PASSOS, “O magistrado, protagonista do processo judicial?”, pp. 218-223, esp. p. 222.

${ }^{439} \mathrm{O}$ que permite ao juiz deixar de aplicar uma lei no caso concreto é a necessidade de equilibrar sua aplicação com os princípios do direito processual, dentre eles, em especial, o princípio instrumental, o qual dita que "o processo deve cumprir seus escopos jurídicos, sociais e políticos, garantindo: pleno acesso ao Judiciário, utilidade dos procedimentos e efetiva busca da justiça no caso concreto" (RUI PORTANOVA, Princípios do processo civil, p. 48). Não concordamos, portanto, com a solução apresentada por VICENTE MIRANDA, que aderiu à "tese dos círculos legais", segundo a qual haveria círculos legais que "de um lado permitem que o julgador aja com liberdade total dentro do espaço traçado pelas linhas que formam o círculo" mas, por outro lado, afirma que "esta liberdade não é, no entanto ilimitada. Não existe apenas, como é óbvio, o espaço circular. Há também as linhas que formam o círculo; estas impedem que o juiz as ultrapasse; formam uma barreira, obstruindo qualquer atividade judicial. Um leve passo fora dessas linhas e o juiz estará pisando no terreno da ilegalidade". Mais uma vez reforçamos nossa filiação à corrente defensora de que o juiz não tem faculdades no processo. Seus poderes não são exercidos de maneira discricionária e ele não escolhe, dentro de um campo de liberdade conferido pela lei, como deve aplicá-la. Quando o juiz deixa de aplicar uma lei ele o faz porque entende que assim deve agir, para garantir que o processo atinja os seus escopos. É evidente que dois ou mais juízes podem chegar a soluções distintas sobre a mesma questão, mas isso não significa que cada um aplique a lei conforme a sua vontade (dentro de um círculo de discricionariedade conferido pela lei) mas, tão somente, que cada um interpreta a lei (e o sistema) de maneira diferenciada. Nesse sentido, v. SIDNEI AMENDOERIA JÚNIOR, Poderes do juiz..., pp. 251264 e BEDAQUE, Tutela cautelar e tutela antecipada: tutelas sumárias e de urgência (tentativa de sistematização), pp. 354-356.
} 
Nem mesmo os critérios de nulidade absoluta e ordem pública são suficientes para limitar essa possibilidade.

À primeira vista tais afirmações podem parecer radicais, mas uma análise dos mais variados exemplos em que esse fenômeno ocorre permite concluir que no processo o juiz é orientado e controlado pela lei, mas não é acorrentado.

Alguns exemplos tirados da melhor doutrina poderão esclarecer essas afirmativas. O Código de Processo Civil estabelece em seu art. 84 que quando a lei considerar obrigatória a intervenção do Ministério Público, a parte promover-Ihe-á a intimação sob pena de nulidade do processo. Trata-se de modalidade de nulidade dita absoluta que pode ser reconhecida de ofício pelo juiz e alegada por qualquer das partes no processo ${ }^{440}$. A clareza com que o legislador impôs a conseqüência de seu reconhecimento nos processos em que, sendo obrigatória a participação do Ministério Público (art. 82 e incisos), ela não tenha ocorrido, deixa pouca margem para interpretação sobre a necessidade de se adotar a medida. Contudo, isso não impediu que surgissem vozes defendendo a inexistência de nulidade quando a não intervenção do Ministério Público não acarretasse prejuízo para a parte cujo interesse seria protegido pela participação do parquet $t^{441}$.

O procedimento é ditado previamente pelo legislador como um meio de conferir segurança às partes e organizar a atividade do juiz. As normas que tratam dele são inegavelmente de interesse público, mas a doutrina relativiza a exigência de observância rígida do rito, tanto através de uma visão retrospectiva do fenômeno ${ }^{442}$, como prospectiva ${ }^{443}$.

\footnotetext{
${ }^{440}$ V. TEREZA ARRUDA ALVIM PINTO, Repertório de jurisprudência e doutrina sobre nulidades processuais, $2^{a}$ série, p. 14.

${ }^{441}$ BEDAQUE, "Nulidade processual e instrumentalidade do processo", pp. 37-38. O ponto de vista do Professor tornou-se vitorioso na jurisprudência, tendo o Superior Tribunal de Justiça proclamado que "não se declara a nulidade, por falta de audiência do MP, se o interesse dos menores se acha preservado, posto que vitoriosos na demanda" ( $3^{\text {a }}$ Turma; REsp 26.898-2-EDcl; rel. Min. DIAS TRINDADE; j. 10.11.92; DJU 30.11.92, p. 22.613, colacionado por NEGRÃO-GOUVÊA-BONDIOLI, Código de processo civil..., nota 4 ao art. 246, p. 370).

${ }^{442}$ V. GALENO LACERDA, "O código e o formalismo processual, p. 10. Embasado nessas lições BEDAQUE, Efetividade do processo..., p. 67, nota 87, afirma que: "Não se nega interesse público na regulamentação do procedimento. Afinal, ela resulta de avaliação prévia feita pelo legislador sobre a
} 
A coisa julgada é entendida como uma garantia constitucional pela maior parte da doutrina, estando assegurada, para alguns pelo art. $5^{\circ}$, inc. $X X X V I^{444}$, e, para outros também art. 50, inc. LIV ${ }^{445}$, como um dos componentes do devido processo legal. Suas limitações são de ordem infraconstitucional, mas, passados os dois anos do trânsito em julgado, não existe qualquer dispositivo legal que a limite. Isso não obstou, todavia, que a doutrina se levantasse em favor da sua relativização para proteger outros valores tão ou mais importantes do que ela ${ }^{446}$.

Diante desses exemplos fica fácil entender que a estrita observância da lei processual não é um dogma para o juiz. A relação de instrumentalidade entre o direito processual e o direito material faz com que a técnica processual seja criada para atingir determinados escopos, fora dos quais ela deixa de ter sentido e pode se tornar um verdadeiro óbice para a busca do processo efetivo $^{447}$.

E, se ao juiz é dado, sob determinadas circunstâncias especiais, afastar a aplicação de uma lei quando sua utilização não se compatibilizar com os objetivos do processo, por idênticas razões deve-se permitir

adequação do meio. Mas, com Galeno Lacerda, insiste-se em acentuar a maior relevância do fim, valor principal da forma processual. O interesse público na determinação do rito está na garantia de outros valores, não dele mesmo".

${ }^{443}$ V. FERNANDO GAJARDONI, Flexibilidade procedimental..., pp. 100 e ss..

${ }^{444}$ SÉRGIO GILBERTO PORTO, Coisa julgada civil, p. 125; EDUARDO TALAMINI, Coisa julgada e sua revisão, pp. 50-53. Apesar de fazerem menção a esse dispositivo, entendem TERESA ARRUDA ALVIM WAMBIER e JOSÉ MIGUEL GARCIA MEDINA, O dogma da coisa julgada - hipóteses de relativização, p. 22, que isso sequer seria preciso, porque a coisa julgada é “umbilicalmente ligada ao Estado Democrático de Direito".

445 Na opinião de BARBOSA MOREIRA, “Considerações sobre a chamada 'relativização' da coisa julgada material”, pp. 247-248, a proteção constitucional da coisa julgada além de ser extraída do art. 5, inc. XXXVI, da Constituição, também se articula com a garantia do devido processo legal (inc. LIV).

${ }^{446}$ Tratamos das teorias sobre a relativização da coisa julgada em nota do tópico 7.6, supra. Embora ela seja bastante controvertida na doutrina pátria, é importante destacar que existem inúmeros processualistas que a defendem, alguns seguindo efetivamente a linha da ‘relativização’ ou ‘flexibilização’ do instituto, outros ampliando o conceito de sentenças inexistentes ou de sentenças 'nulas ipso iure' ou, ainda, enfocando a questão do ponto de vista da 'coisa julgada inconstitucional'. Dentre os principais nomes dessas correntes destacam-se, além de CÂNDIDO RANGEL DINAMARCO e EDUARDO TALAMINI, já citados, DONALDO ARMELIN, JOSÉ DELGADO, HUMBERTO THEODORO JÚNIOR, TERESA ARRUDA ALVIM WAMBIER, JOSÉ MIGUEL GARCIA MEDINA e JOSÉ MARIA TESHEINER.

${ }^{447}$ Esse é o sentido da observação precisa de BEDAQUE, Efetividade do processo..., p. 64: "Para tanto, deve ser o juiz investido de amplos poderes de direção, possibilitando-lhe adaptar a técnica aos escopos do processo em cada caso concreto, mesmo porque a previsão abstrata de todas as hipóteses é praticamente impossível”. 
a ele que, deixando de aplicar uma lei nova, determine a sobrevivência da lei antiga para regular uma situação concreta no curso do processo ${ }^{448}$.

Para que se possa defender essa idéia, contudo, é necessário traçar limites para a forma de atuação do juiz, bem como analisar os mecanismos de controle que a justificam, a fim de impedir que ele atue livremente nesse sentido.

Antes de estudar esses limites, é importante tecer um esclarecimento de ordem metodológica. Quando se permite que o juiz controle, sob certas circunstâncias, a eficácia temporal de uma lei processual, não se está a propor a ausência de um sistema de direito intertemporal e o recurso ao casuísmo para a solução dos seus problemas. O sistema existe e deve ser observado. Os poderes do juiz inserem-se dentro desse sistema e, como se verá a seguir, as hipóteses em que podem ser utilizados são excepcionais. A compreensão de que os juízes detêm poderes para, eventualmente, afastar a eficácia imediata de uma lei não implica no recurso ao casuísmo para a compreensão do modo como devem ser aplicadas as normas processuais aos processos pendentes. Diante de cada caso prático o juiz deverá sempre partir dos postulados do sistema para entender se uma norma deve ou não ser aplicada a um processo pendente. Como regra geral, deverá pautar-se nesses postulados para dar aplicação à norma. Em casos particulares em que ele entenda que a eficácia imediata da norma poderá ser prejudicial ao sistema, deverá, antes de decidir pelo seu afastamento, indagar se ele pode fazer isso, o que deverá ser respondido pelas limitações que o sistema lhe impõe. Por fim, ao fazê-lo, terá que respeitar as garantias das partes. Não se pode falar, portanto, que esse método corresponda a uma defesa do casuísmo para as soluções de direito processual intertemporal.

\footnotetext{
${ }^{448}$ Conforme já mencionado no Capítulo VI, a idéia da influência dos princípios processuais sobre a eficácia temporal da norma processual foi defendida por FÁBIO TABOSA PESSOA, Elementos para uma teoria..., pp. 184-186 e p. 190.
} 


\subsection{Limites dos poderes do juiz no controle da eficácia temporal das leis}

O primeiro limite para essa forma de atuação judicial será a segurança jurídica, que implica na preservação dos direitos processuais adquiridos.

A proteção subjetiva aos direitos das partes no processo é necessária para manutenção da segurança que dele se espera. Ela se insere no conceito de direito adquirido assegurado pela Constituição, e não é dado nem ao legislador nem ao juiz atingi-la. Uma vez interposto um recurso que seja admitido pelo ordenamento, lei posterior que venha a suprimir essa possibilidade de atuação das partes não atingirá os recursos ainda não julgados, nem que disponha expressamente que sua aplicação deverá ser retroativa ${ }^{449}$. A mesma limitação atinge os poderes do juiz, que não poderá justificar o não conhecimento do recurso ao entendimento de que tal fato propiciaria maior efetividade ao processo.

O nível de insegurança que se criaria caso se admitisse essa conduta seria verdadeiramente insuportável, de modo a tornar injustificável, a partir da busca para atingir os escopos do processo, a concessão de poderes com tamanha amplitude ao juiz. Vale lembrar que em toda seara dos direitos processuais adquiridos não existe qualquer espaço para se pensar em conflito entre as expectativas de segurança das partes e do juiz. Os direitos das partes no processo não limitam a forma de atuação da parte contrária e não distanciam o juiz da realidade que compõe o litígio. Mesmo quando se pensa nos negócios jurídicos processuais o campo reservado para as partes efetuarem tratativas é restrito às matérias que sejam ditadas para proteção de seus interesses. As matérias afetas ao interesse da jurisdição são indisponíveis e não podem ser objeto de negociação.

\footnotetext{
449 "Isso porque, proferida a decisão, a partir desse momento nasce o direito subjetivo à impugnação, ou seja o direito ao recurso autorizado pela lei vigente nesse momento. Estamos, assim, em presença de verdadeiro direito adquirido processual, que não pode ser ferido por lei nova, sob pena de ofensa à proteção que a Constituição assegura a todo e qualquer direito adquirido" (GALENO LACERDA, O novo código de processo civil..., p. 68).
} 
Além de não poder ferir direitos adquiridos, o poder do juiz será limitado pela finalidade do ato. O magistrado não pode escolher entre conferir ou não aplicação a uma lei nova no processo. Nem mesmo se ele entender que essa lei é pior do que a anterior, e, portanto, prejudicial para que o processo possa atingir seus escopos. A análise de oportunidade e conveniência de alteração da norma processual é feita pelo legislador, não pelo juiz. É aquele quem pensa no modelo abstrato que terá maior aptidão para, equilibrando as limitações de tempo e recursos, assegurar da forma mais satisfatória possível a realização da Justiça ${ }^{450}$.

O juiz somente poderá deixar de conferir eficácia imediata a uma determinada norma processual quando essa aplicação for contrária aos próprios objetivos da lei ${ }^{451}$.

\section{O direito processual regulamenta uma série de normas} técnicas que visam possibilitar ao juiz um melhor desempenho de sua atividade. Essas normas são previstas de modo abstrato pelo legislador, que exerce seu poder mediante restrições de ordem prática. Ele não pode vislumbrar um número

${ }^{450}$ Pedimos licença para utilizar de maneira invertida um bom exemplo utilizado por GAJARDONI para justificar a flexibilização do procedimento. O processualista capixaba vislumbrou a hipótese de realização de audiência de instrução antes da determinação de perícia em processos nos quais a oitiva das partes e das testemunhas possa resultar na desnecessidade de realização da prova técnica, que normalmente é bem mais demorada e custosa (Flexibilidade procedimental..., p. 104). Imaginemos um exemplo contrário, em que desde a chegada da contestação seja possível ao juiz perceber que a prova técnica será imprescindível. Suponhamos, ainda, que esse juiz se utilize dos serviços de um perito com notável conhecimento na área há muitos anos e que, em virtude do relacionamento profissional desenvolvido durante todo esse tempo, tenha chegado ao seu conhecimento que o perito irá se mudar para o exterior em breve. Pensemos agora que, no início da fase instrutória, sobrevenha uma lei que altera a ordem de realização das provas e determine que seja feita uma audiência de instrução antes da realização da perícia, justamente para tentar evitar esse ato. Devemos ainda incluir mais um dado nesse problema: a pauta do juiz. É de se imaginar que, como grande parte dos juízes paulistas, sua pauta esteja sobrecarregada e ele não poderá marcar a audiência para uma data anterior à viagem do perito. Nesse caso, pode ele deixar de conferir eficácia imediata à lei e, seguindo a sistemática anterior, realizar a perícia antes da audiência? Pensamos que sim. A aplicação imediata da lei no caso concreto não atingirá o seu escopo, porque a perícia será necessária. Por outro lado, sua aplicação causará prejuízo para o desenvolvimento do processo (que terá que contar com um ato a mais) e, ainda, impedirá o juiz de se utilizar dos serviços de um profissional que já é da sua confiança.

${ }^{451}$ Quando mencionamos os objetivos da norma, devemos entendê-la dentro do sistema e não de maneira isolada, pois, como bem adverte EROS GRAU, “não se interpreta o direito em tiras" (Ensaio e discurso sobre a interpretação/aplicação do direito, p. 40). FERNANDO GAJARDONI incluiu entre os requisitos necessários para a flexibilização do procedimento a finalidade e explicou-a mediante a análise de três situações específicas (Flexibilidade procedimental..., pp. 104-105), uma relacionada com o direito material, outra com a higidez e utilidade dos procedimentos e a terceira vinculada à condição da parte. Não discordamos dos exemplos citados, mas preferimos a vinculação da finalidade com os objetivos da norma por entendermos que é mais abrangente. 
infinito de relações jurídicas possíveis e ditar regras específicas para cada uma delas. Não pode, além do mais, pensar em todos os estágios em que cada uma dessas relações se encontram, para determinar regras transitórias individualizadas para esses estágios ${ }^{452}$.

As lacunas da lei processual intertemporal, tanto no que diz respeito a normas gerais como a dispositivos de caráter transitório, são grandes o suficiente para dotar o juiz de poderes nessa área. Sua atuação, contudo, deverá se dar para garantir a harmonia e funcionalidade do sistema, e não para contrariálo. Quando deixa de conferir eficácia imediata a uma norma processual o juiz faz um trabalho de "sintonia fina", conferindo a ela uma forma de aplicação que lhe permita atingir melhores resultados na prática. Para tanto, ele não pode ignorar a existência da norma e sua aptidão para produzir efeitos imediatos, quando for 0 caso.

\subsection{Modo de funcionamento dos poderes do juiz em matéria de direito intertemporal}

A primeira questão que envolve o exercício dos poderes do juiz em matéria de direito intertemporal consiste em saber se sua atuação depende de provocação das partes ou, ao contrário, se pode se dar de ofício.

Sem dúvida optamos pela segunda alternativa. As próprias limitações do juiz nessa seara conduzem a essa solução. De fato, sendo certo que o juiz somente poderá afastar a eficácia imediata de uma lei processual quando o fizer para preservar os escopos do processo, fica fácil associar esses

\footnotetext{
${ }^{452}$ MAURO CAPPELLETTI, Juízes legisladores?, pp. 31 e ss., traça um paralelo entre o crescimento das funções do Estado a partir do welfare state e a necessidade de se legislar através de tipos abertos - que deixam maior margem para a interpretação judicial das leis -, a fim de viabilizar não só a possibilidade de regulação das mais diversas relações jurídicas da sociedade moderna como, ainda, para permitir que o direito evolua tão rapidamente quanto a sociedade exige. O mesmo caminho é seguido por EDUARDO DE ALBUQUERQUE PARENTE, "Jurisdição e poder", pp. 190-191, que entende esse aumento de poder concedido ao juiz como uma forma de conferir "discricionariedade" a ele, fazendo a ressalva de que essa não deve ser entendida com o mesmo significado que tem no direito administrativo. Pensamos que, sendo assim, melhor será definir o fenômeno de outra maneira para não gerar equívocos.
} 
poderes àqueles que parte da doutrina classifica de poderes meios ${ }^{453}$, porque serão exercidos (a) ou para garantir maior eficiência na marcha processual, quer auxiliando sua coordenação ou sua celeridade (b) ou para permitir uma melhoria na colheita de elementos necessários à formação do convencimento do juiz.

Tais poderes, sendo exercidos em prol da maior eficiência da atividade jurisdicional, interessam não somente às partes, mas, principalmente ao juiz, que não pode ficar atrelado à vontade daquelas para exercê-los ${ }^{454}$.

Não se pode questionar, destarte, que esses poderes serão exercidos de ofício pelo juiz.

Outra questão que deve ser levada em consideração é a de saber se o reconhecimento desses poderes implicará na adoção do sistema de "fases processuais" ou na utilização misturada desse sistema com o do "isolamento dos atos processuais".

Pensamos que em qualquer hipótese a menção a esses sistemas somente pode gerar equívocos. Quando se permite ao juiz afastar a eficácia imediata da lei em um caso concreto isso pode se dar tanto para manter uma coordenação de atos, como para perseguir outro objetivo no processo (no exemplo que citamos da inversão da probatória estava-se buscando a economia de atos e o fortalecimento da prova pericial para o juiz). Em qualquer das hipóteses não haverá adoção integral ou misturada do sistema de fases processuais. Mesmo nos casos em que uma determinada norma venha a ser aplicada de modo a respeitar uma fase processual, isso não impedirá que outras normas tenham eficácia imediata sobre esse processo. É fácil supor que uma lei que trate de competência e de requisitos para a prática de atos processuais possa

\footnotetext{
${ }^{453}$ GRINOVER-CINTRA-DINAMARCO, Teoria geral do processo, p. 294.

454 "A sistemática do Código brasileiro de 1973 afeiçoa-se, no essencial, aos ditames da moderna concepção do processo civil. Ao juiz continua vedado, como é da tradição, pôr em movimento, ex officio, a máquina judiciária; mas, uma vez instaurado, desenvolve-se o feito por impulso oficial (art. 262). Sem embargo de faculdades conferidas às partes (vide, infra, $n^{\circ} 6$ ), a direção formal do processo é, sem dúvida, função precípua do órgão judicial, a que a lei impõe, de modo significativo, o dever de 'velar pela rápida solução do lítigio’ (art. 125, $n^{\circ}$ II)” (BARBOSA MOREIRA, “A função social do processo civil moderno e o papel do juiz e das partes na direção e na instrução do processo”, p. 51).
} 
ao mesmo tempo ter dispositivos com a eficácia afastada pelo juiz (ou pelo legislador) e outros aplicados imediatamente, numa mesma fase processual.

A idéia de fases processuais, portanto, somente tem importância para efeitos didáticos de demonstração da maneira como alguns atos processuais detêm maior vínculo entre $\mathrm{si}^{455}$. De igual forma a do isolamento dos atos processuais, se entendida ao pé da letra, pode ocasionar o desrespeito aos direitos processuais adquiridos. Sua principal importância consiste em realçar a necessidade de preservação dos efeitos das situações jurídicas constituídas antes do advento da alteração legislativa, nos casos de aplicação imediata da lei, mas, para tanto, basta a noção de irretroatividade, sendo desnecessário criar um 'sistema' para explicá-la.

Afastando-se dessas idéias de 'sistemas' pré-concebidos de direito processual intertemporal, tem-se que, quando o juiz deixa de conferir eficácia imediata a uma lei processual ele não se vincula a isolar uma fase do processo contra alterações legislativas. Ele apenas deixa de aplicar uma determinada lei, ou alguns de seus dispositivos.

Um último aspecto que precisa ser lembrado para explicar o modo como um juiz pode afastar a eficácia imediata de uma lei é a necessidade de que esse poder seja exercido de maneira expressa. Quando o juiz faz uso dele, está tomando uma decisão de não aplicar uma lei que, em tese, deveria surtir efeitos no processo em que deixou de ser aplicada. Essa decisão, como toda e qualquer outra, precisa ser expressa para que seja fundamentada.

\footnotetext{
${ }^{455}$ Até porque, "pode conceber-se, in abstracto, um esquema de procedimento em que para cada qual dessas atividades se reserve uma fase nitidamente diferenciada. Na prática, todavia, considerações várias de política legislativa conduzem à atenuação desse rigor estrutural" (BARBOSA MOREIRA, O novo processo civil brasileiro, p. 5). 23 ${ }^{\mathrm{a}}$ ed., Rio de Janeiro: Forense, 2.005.
} 


\subsection{Poderes do juiz e direito processual intertemporal - garantias contra excessos}

Não existe razão para temer que o reconhecimento da existência de poderes do juiz para afastar a eficácia imediata de leis processuais, nos moldes ora explicados, torne o processo inseguro ou arbitrário.

Primeiramente, porque, como dito, os direitos processuais adquiridos deverão ser respeitados. A esfera de direitos das partes no processo permanecerá resguardada.

Por outro lado, a vinculação desse poder a uma finalidade relativa à melhor utilização da norma dentro do sistema é, por si, garantia suficiente contra arbitrariedades do juiz. Conforme demonstrado, a proposta não é nova e consiste apenas na visualização de um problema antigo - possibilidade de o juiz deixar de aplicar dispositivos processuais - sob o enfoque do direito intertemporal ${ }^{456}$.

As garantias que se tem para coibir excessos do juiz são as que o sistema já confere para controlar seus demais poderes. Pode-se dizer que elas são bastante eficazes, pois, mesmo sendo tais poderes bastante amplos, não ocasionam maiores perplexidades quanto a uma utilização excessiva ou degenerada ${ }^{457}$.

\footnotetext{
${ }^{456} \mathrm{Em}$ que pese a possibilidade de afastamento de uma norma não ser um problema novo, sua abordagem a partir do enfoque do direito intertemporal não deixa de ser útil, tanto para reforçar a tese de que o juiz detém poderes para deixar de aplicar uma lei no processo, demonstrando que o direito intertemporal não obsta essa forma de atuação, como, principalmente, para esclarecer quais são seus limites do ponto de vista do direito intertemporal (respeito aos direitos processuais adquiridos). Por outro lado, o estudo desse fenômeno serve de alerta para as peculiaridades da lei processual civil em matéria de direito intertemporal, o que, em certa medida, pode contribuir para que o legislador processual não relegue o tratamento exclusivo da matéria às disposições gerais.

${ }^{457}$ Pelo contrário, em matéria de utilização dos poderes conferidos pela lei o que se verifica é um uso bastante tímido por parte dos juízes, sendo comum que a doutrina entenda que o legislador foi mais ousado em conferir poderes aos juízes do que esses em utilizá-los. São expressivas nesse sentido as palavras de GALENO LACERDA, "O código e o formalismo", p. 14, analisando o sistema de nulidades do CPC depois de dez anos de sua vigência: "Posso afirmar, e o faço agora com a experiência e o amadurecimento de Juiz, que esse sistema é profundamente antiformalista. As disposições analisadas se expandem como largas avenidas de abertura, a permitir ao Juiz trânsito livre para o milagre, sem os tropeços da forma e da letra, de fazer justiça de acordo com a própria consciência, amparado em dispositivos do próprio Código.
} 
A primeira e mais importante delas é um desdobramento da finalidade que limita o poder do juiz: a fundamentação.

Como visto no tópico acima, sempre que o juiz entender por afastar a aplicação imediata de uma lei ele deverá proferir uma decisão e fundamentá-la. A fundamentação das decisões judiciais exerce um papel extremamente relevante no controle do uso arbitrário do poder, porque impõe ao juiz o dever de explicar sua utilização ${ }^{458}$. O esquema mínimo de uma decisão que implique em deixar de conferir eficácia imediata a uma lei processual deverá conter (i) o reconhecimento de que essa lei seria aplicável ao processo em curso e (ii) as peculiaridades do caso que conduzem o juiz ao entendimento de que sua aplicação, naquela demanda, não permitirá atingir os objetivos da norma e, ainda, ocasionará prejuízos para os escopos do processo.

A garantia da fundamentação, por outro lado, permite que se estabeleça um diálogo entre as partes, não necessariamente no sentido de consulta prévia sobre sua concordância na utilização da medida ${ }^{459}$, mas, ao menos, no de permitir-Ihes que tomem conhecimento dos motivos que orientaram o juiz na tomada de decisão. A partir daí, fica mais fácil para elas exercitarem a segunda garantia que o sistema confere contra arbítrios por parte dos juízes: o recurso $0^{460}$.

Percebe-se, então, que os obstáculos e protelações resultam muito menos de defeitos do texto do que da falta de percepção, por quem o aplica ou interpreta, da esplêndida abrangência de princípios basilares, consagrados em preceitos norteadores".

${ }^{458}$ FERNANDO GAJARDONI inclui a necessidade de fundamentação dentre os requisitos para a implementação de variações rituais no processo e explica: "É na análise da fundamentação que se afere em concreto a imparcialidade do juiz, a correção e justiça dos próprios procedimentos e decisões proferidas" (Flexibilidade procedimental..., pp. 110-111).

${ }_{459}$ Estamos no campo da utilização de um poder-dever do juiz de conduzir o processo da forma mais adequada possível. A concordância das partes a propósito da sua utilização é irrelevante. Isso não impede, e a melhor técnica até recomenda, que, havendo possibilidade, o juiz dê oportunidade para as partes se manifestarem previamente sobre os possíveis inconvenientes da adoção da medida a fim de colher novos elementos para orientá-lo na decisão a ser tomada. Nesse sentido, v. DINAMARCO, Fundamentos do processo civil moderno, tomo I, p. 135; FERNANDO GAJARDONI, Flexibilidade procedimental..., pp. 105110; e LUIGI MONTESANO, "La garanzia costituzionale del contradditorio", pp. 929 e ss.

${ }_{460}$ De se destacar a observação pontual de GUILHERME SILVEIRA TEIXEIRA, Ampliação dos poderes do juiz nas recentes reformas processuais e a necessidade de equilíbrio entre segurança e efetividade do processo, p. 75, acerca dessa questão: "a par do controle endoprocessual realizado pelos meios de impugnação (recursos e ações impugnativas autônomas) - vale dizer, ferramentas imprescindíveis à contenção dos poderes do juiz no desenvolvimento da relação processual -, a motivação constitui, ainda, elemento indispensável ao controle extraprocessual e público das decisões judiciais, na medida em que 
Nosso sistema processual civil é pautado pela recorribilidade das decisões interlocutórias, o que permite às partes exercerem amplo controle sobre a atividade jurisdicional arbitrária na medida em que poderão submeter a decisão judicial à fiscalização de outro órgão jurisdicional ${ }^{461}$. Com isso resta diminuído o espaço para excessos por parte do juiz ${ }^{462}$.

Além dessas garantias deve-se ainda mencionar que a atividade do juiz se submete a controles de ordem administrativa, os quais, se não permitem à parte usufruir de qualquer benefício imediato em razão de um deslize arbitrário cometido no curso do processo, servem como mecanismos de pressão que coíbem tais comportamentos, porque o juiz sabe que se agir com excesso poderá receber uma punição administrativa ${ }^{463}$.

\subsection{Poderes do juiz em matéria de direito intertemporal e competência absoluta: mais uma limitação?}

Questão bastante tormentosa é a de saber se é possível ao juiz afastar a incidência imediata de lei dispondo sobre competência absoluta. A indagação tem pertinência não pelo caráter público da norma que trata dessa

permite à opinião pública e ao jurisdicionado em geral conhecer os motivos invocados pelo Poder Judiciário na resolução dos conflitos que lhe são submetidos".

${ }^{461}$ Leciona ALCIDES DE MENDONÇA LIMA, Introdução aos recursos cíveis, p. 135 que: "o recurso, além de sua função jurídico-processual, exerce, ainda, uma finalidade eminentemente política, como meio de resguardar as liberdades individuais contra o arbítrio, o despotismo e as fraquezas dos juízes de primeira instância, que, pelas condições ambienciais, se podem tornar mais sensíveis às influências dos poderosos, com reflexos, pois, na preservação dos próprios direitos individuais.” Ressalvamos nossa discordância com a parte final do ensinamento, porque não acreditamos que os juízes de primeiro grau sejam mais sensíveis às influências dos poderosos.

${ }^{462}$ ITALO ANDOLINA e GIUSEPPE VIGNERA, Il modello costituzionale del processo civile italiano, corso di lezioni, p. 181, demonstram que a necessidade de "oferecer" os motivos da decisão às partes, submetendo-a à possibilidade de impugnação exerce uma influência sobre o juiz, induzindo-o a "una maggiore ponderazione ed alla ricerca di soluzioni che, in quanto conformi al diritto (o, comunque, presentate come tali), possano consentire di affermare l'avvenuto adempimento del suo dovere istituzionale di 'suddito e garante della legalità' e di evitare ogni sospetto di abuso, arbitrarietà o parzialità".

463 "Assim é que a responsabilidade disciplinar, provindo de um núcleo essencialmente publicístico, tem por finalidade assegurar, com uma gradação de sanções disciplinares, que os juízes, no exercício de suas funções de órgãos do poder que integram, observem os deveres do seu ofício, tipicamente de direito público, perante o Estado e toda a sociedade" (WALDEMAR ZVEITER, “O controle do Poder Judiciário", pp. 6869). No mesmo sentido é a lição de MAURO CAPPELLETTI, Juízes irresponsáveis?, p. 71. 
modalidade de competência, pois, como vimos, existem exemplos bastante variados de outras leis processuais de igual caráter, cuja possibilidade de não ser aplicada é admitida pela jurisprudência.

O que justifica essa indagação é o modo como o sistema trata a conseqüência de um processo viciado pela condução de juiz absolutamente incompetente, possibilitando que esse vício seja utilizado para requerer a rescisão da sentença (ou acórdão) já transitada em julgado (art. 485, inc. II). Diante dessa possibilidade pode-se supor que a condução do processo por um juiz absolutamente incompetente não conferirá a segurança adequada às partes, porque todos os atos processuais, inclusive a coisa julgada, permanecerão em estado latente de incerteza, podendo a qualquer momento sobrevir uma decisão que reconheça o vício e determine que o processo regresse ao estágio em que estava quando passou a ser conduzido por juiz incompetente ${ }^{464}$.

Antes de respondermos à indagação, afirmamos que nossas mais altas cortes se utilizam desse poder.

Os casos mais comuns em que o controle de eficácia temporal da lei sobre competência é utilizado referem-se ao modo de aplicação da nova legislação aos processos já sentenciados. Não é de hoje que existe uma orientação jurisprudencial afirmando que as alterações de competências absolutas não se aplicam a processos com sentença de mérito ${ }^{465}$.

Tais entendimentos consistem, na prática, em controle da eficácia temporal das normas que alteram competências absolutas. Isso porque,

\footnotetext{
464 Mutatis mutandis é possível explicar o problema pela seguinte observação feita por BARBOSA MOREIRA, “Considerações sobre a chamada 'relativização' da coisa julgada material”, p. 261: "Suponhamos que um juiz, convencido da incompatibilidade entre certa sentença e a Constituição, ou da existência, naquela, de injustiça intolerável, se considere autorizado a decidir em sentido contrário. Fatalmente sua própria sentença ficará sujeita a crítica da parte agora vencida, a qual não deixará de considerá-la, por sua vez, inconstitucional, ou intoleravelmente injusta. Pergunta-se: que impedirá esse litigante de impugnar em juízo a segunda sentença, e outro juiz de achar possível submetê-la ao crivo de seu próprio entendimento?”.

${ }^{465}$ Com relação às competências alteradas pela E.C. $n^{\circ}$ 45/04 a matéria foi pacificada no Superior Tribunal de Justiça com a edição da Súmula $n^{\circ} 367$, cujo verbete tem o seguinte teor: "A competência estabelecida pela EC n. 45/2004 não alcança os processos já sentenciados”.
} 
não existe no nosso sistema uma regra que dite a perpetuação da competência absoluta após a decisão do mérito da demanda. A análise fria da matéria do ponto de vista do direito intertemporal determina a imediata remessa dos autos ao novo juízo competente, respeitando-se os atos que foram validamente praticados por aquele então dotado de competência. Os recursos proferidos contra sentenças de mérito, em tese, devem ser julgados pelos tribunais que passaram a deter competência para o julgamento da matéria.

Se uma demanda foi julgada por um juiz federal e a matéria nela tratada passou a ser da competência da Justiça do Trabalho, o Tribunal Regional do Trabalho é quem deverá julgar o recurso ${ }^{466}$.

Esse raciocínio poderia ser objeto de ressalva partindo-se das redações dos dispositivos da Constituição Federal e das Constituições Estaduais que ditam a competência recursal dos Tribunais.

Para exemplificar, vejamos como a matéria é tratada no âmbito da Justiça Federal. A competência dos juízes federais é ditada no art. 109 da Constituição Federal e a competência recursal dos Tribunais Regionais Federais no art. 108, inc. II, da seguinte forma: "Art. 108. Compete aos Tribunais Regionais Federais: (...) II - julgar, em grau de recurso, as causas decididas pelos juízes federais e pelos juízes estaduais no exercício da competência federal da área de sua atuação".

De fato, uma leitura do art. 108, caput e inc. II, da Constituição Federal, poderia levar ao entendimento de que a competência dos Tribunais se estabelece em função do órgão prolator da decisão, e não da matéria. Prosseguindo nesse raciocínio, restaria concluir que a prolação da

\footnotetext{
${ }^{466}$ Como a alteração refere-se somente à competência, as condições de admissibilidade do recurso permanecem inalteradas. O Tribunal Regional do Trabalho deverá, então, analisá-las de acordo com a legislação pertinente ao recurso de apelação, e não do recurso ordinário. Por uma questão de boa-fé, deverá, ainda, pautar-se pela orientação jurisprudencial da Justiça que era competente para apreciação desses requisitos de admissibilidade no momento de interpretar se eles foram corretamente preenchidos. A propósito da aplicação da boa-fé objetiva ao processo, para evitar que as partes que praticaram seus atos pautados por uma determinada orientação da própria jurisprudência sejam surpreendidas com uma súbita alteração, v. MARCELO PACHECO MACHADO, Incerteza e processo..., pp. 100-103.
} 
sentença seria um marco temporal para determinar a perpetuatio jurisdictionis no campo da competência absoluta.

Mas, essa não parece ser a melhor exegese do dispositivo em análise. O que o constituinte quis efetivamente foi coordenar o âmbito de competências dentro de cada uma das Justiças, estabelecendo um nexo de atribuições entre os juízes de primeiro e segundo graus. Cada Justiça detém a atribuição de julgar determinada matéria (ou determinadas pessoas) e, dentro delas, como regra, os Tribunais devem julgar os recursos proferidos pelos juízes de primeiro grau. Isso não significa que a Constituição quis ditar a competência dos Tribunais partindo do órgão prolator da decisão recorrida. Tanto não foi essa a intenção da Constituição que os recursos interpostos contra decisões proferidas por juízes estaduais exercendo competência da justiça federal também são julgados pelos Tribunais Regionais Federais ${ }^{467}$.

O raciocínio contrário poderia gerar sérios inconvenientes para as demandas com pedidos cumulados. De fato, devemos ter em mente que a orientação da jurisprudência caminha no sentido de afirmar que a lei nova sobre competência somente não atinge os processos em que há uma sentença de mérito $^{468}$. Imaginemos, contudo, que em um processo com dois pedidos cumulados, um deles tenha sido apreciado no mérito e o outro não ${ }^{469}$. Como ficaria a competência do órgão de segundo grau para julgamento da matéria?

Seguindo-se a linha de raciocínio de que a perpetuação da competência ocorre com o julgamento de mérito, esse fenômeno seria aplicável somente a um dos pedidos. Sobrevindo lei que alterasse a competência na

\footnotetext{
${ }^{467}$ DINAMARCO, depois de efetuar um primeiro corte vertical para explicar a posição do Supremo Tribunal Federal e do Superior Tribunal de Justiça dentro da estrutura judiciária brasileira, esclarece que, "no plano horizontal, alinham-se as diversas Justiças, cada uma com sua quantidade de jurisdição a exercer (causas afetas a cada uma delas) e sem que nenhuma interfira nas outras" (Instituições..., vol. I, p. 365).

${ }^{468}$ Informam NEGRÃO-GOUVÊA-BONDIOLI, Código de processo civil..., nota 7 ao art. 87, p. 229, que: "A $1^{a}$ Seção do STJ decidiu que a prévia sentença terminativa não é suficiente para a fixação da causa na Justiça anteriormente competente para o seu julgamento e aplicou ao caso as novas regras de competência (STJ-1 ${ }^{a}$ Seção; CC 88.883, Min. Teori Zavascki, j. 14.11.07, DJU 10.12.07)”.

${ }^{469} \mathrm{O}$ problema pode se tornar mais comum caso se entenda que com a nova redação conferida aos artigos 162, $\S 1^{\circ}$ e 269 , ambos do CPC, nosso sistema passou a admitir as sentenças parciais de mérito, como defendem, dentre outros, BRUNO SILVEIRA OLIVEIRA, “Um novo conceito de sentença?”, e HEITOR VITOR MENDONÇA SICA "Algumas implicações do novo conceito de sentença no processo civil, de acordo com a lei $\mathrm{n}^{\circ} 11.232 / 2005^{\prime \prime}$.
} 
pendência do julgamento de apelação, teríamos a curiosa situação em que o Tribunal somente deteria competência para julgar um dos pedidos, ainda que 0 grau de conexidade entre eles fosse bastante acentuado e que, de acordo com a sistemática prevista em abstrato pela norma que alterou a distribuição da competência, a matéria relativa a esses dois pedidos permanecesse integralmente pertencendo a uma única Justiça ${ }^{470}$. Ao receber o recurso, se o Tribunal entendesse que o juiz equivocou-se ao deixar de analisar o mérito do segundo pedido, teria, então, que anular a decisão, desmembrar a demanda e remeter os autos ao juízo de primeiro grau da Justiça competente, em nítido prejuízo para a celeridade (porque não poderia aplicar o art. 515 , $\S 3^{\circ}$, do CPC e julgar diretamente o mérito desse pedido) e para a harmonia de julgados que a lei buscou alcançar ao possibilitar a reunião de pedidos em uma única demanda ${ }^{471}$.

A compreensão de que as normas que estabelecem a competência dos Tribunais não são ditadas em função do órgão de primeiro grau, mas por um critério ditado pela natureza da relação jurídica substancial ou de seus elementos ${ }^{472}$, não gera esse inconveniente porque nos casos análogos aos do exemplo citado a competência permanecerá pertencendo exclusivamente a um único órgão de segundo grau.

Se esses argumentos não forem suficientes para demonstrar que efetivamente não existe regra no nosso sistema prevendo a perpetuatio jurisdictionis relativamente à competência absoluta, a jurisprudência do Superior Tribunal de Justiça acerca da alteração da competência absoluta em virtude de mudança de elementos subjetivos da demanda servirá de importante reforço argumentativo nesse sentido. Deveras, o entendimento desse Tribunal é firme no sentido de que tais mudanças implicam na alteração imediata da competência, independentemente da fase em que o processo estiver. A propósito, enuncia a Súmula 365 que: "A intervenção da União como sucessora da Rede Ferroviária

\footnotetext{
${ }^{470}$ Isso porque, conforme esclarece BRUNO SILVEIRA OLIVEIRA, Conexidade e efetividade processual, pp. 232-233, não é permitida a conexão de demandas para as quais o sistema preveja competências absolutas distintas.

${ }^{471}$ Tratando da modificação legal da competência que é a hipótese que permite a prorrogação ou a derrogação da competência em função da conexidade entre demandas demonstra BRUNO SILVEIRA que ela "visa à obtenção de julgados harmoniosos e à providência de maiores doses de economia à atividade jurisdicional" (Conexidade..., p. 226).

${ }^{472}$ BEDAQUE, Direito e processo..., p. 79.
} 
Federal S/A (RFFSA) desloca a competência para a Justiça Federal ainda que a sentença tenha sido proferida por Juízo estadual”473.

Afastada a possibilidade de se extrair dos dispositivos constitucionais uma regra de perpetuação da competência para os Tribunais, fica fácil entender que quando nossas Cortes aplicam o posicionamento de que a alteração de competência não alcança os processos já sentenciados, elas estão, de fato, modulando a eficácia temporal dessa lei.

Poder-se-ia argumentar, então, que esses casos são aplicados de maneira geral para todos os processos que se encontram na mesma situação, que partem de um entendimento do modo como o próprio sistema regulamenta a solução do problema, o que afastaria, assim, a possibilidade de afirmação de que os juízes detenham poderes nessa área.

Tal afirmativa, contudo, destoa da realidade. Apesar das justificativas apresentadas para essa solução, na maioria das vezes, passarem ao largo da problemática dos poderes do juiz, é possível encontrar posicionamentos que a justificam do ponto de vista da política judiciária ${ }^{474}$, o que se distancia bastante de uma interpretação do sistema de direito processual civil intertemporal.

\footnotetext{
${ }^{473}$ Em sentido análogo encontra-se aresto afirmando que a habilitação na demanda de empresa pública federal como assistente litisconsorcial tem o efeito de transferir a competência para julgamento da rescisória da Justiça Estadual para a Federal (v. NEGRÃO-GOUVÊA-BONDIOLI, Código de processo civil..., p. 53, nota 108 1b).

${ }^{474}$ Essa é a posição do Supremo Tribunal Federal, exarado primeiramente no julgamento do CC 7.2041/MG, da relatoria do Ministro CARLOS BRITTO. No Superior Tribunal de Justiça a orientação foi seguida no julgamento do AgRg no CC 88850/RN, conforme se pode ler na parte final de sua ementa: CONFLITO NEGATIVO DE COMPETÊNCIA. MULTA TRABALHISTA. EXECUÇÃO FISCAL. EMENDA CONSTITUCIONAL N ${ }^{\circ}$ 45/04. 1. A partir da Emenda Constitucional $n^{\circ} 45$, de 2004, cabe à Justiça do Trabalho processar e julgar "as ações relativas às penalidades administrativas impostas aos empregadores pelos órgãos de fiscalização das relações de trabalho" (art. 114, VII, da CF/88), salvo se já houver sido proferida sentença de mérito na Justiça comum, quando então prevalecerá a competência recursal do tribunal respectivo. (...) 6. Como nas execuções fiscais não há sentença de mérito propriamente dita, a decisão do Supremo que fixa como marco temporal de incidência das novas regras de competência a prolação de sentença de mérito deve ser adaptada para se entender possível a aplicação da Emenda somente às execuções ajuizadas posteriormente a 31 de dezembro de 2004 e, também, àquelas que, propostas anteriormente, não se tenham tornado definitivas pela ausência de embargos ou por ter-se consumado seu julgamento. 7. A decisão do Supremo foi adotada, basicamente, por razões de política judiciária, que também deve ser aplicada neste caso, evitando-se que execuções antigas e já devidamente aparelhadas na Justiça Federal sejam deslocadas desnecessariamente à Justiça do Trabalho. 8. Agravo regimental provido (Primeira Seção; rel. para acórdão Min. CASTRO MEIRA; j. 10.09.08; DJe 19.12.08, sublinhamos - fonte: www.stj.jus.br, último acesso em 09.01.10 às 16:00h).
} 
Por outro lado, acham-se acórdãos que estendem sua aplicação para processos que não tenham sido sentenciados ${ }^{475}$, e até mesmo que o tenham, mas por órgão jurisdicional incompetente ${ }^{476}$.

Em todos esses exemplos pode-se notar que a solução não foi feita partindo-se dos parâmetros ditados pelo sistema de direito intertemporal, mas a partir da necessidade de conferir uma solução para um caso concreto.

Não é nossa intenção utilizar argumento de autoridade para demonstrar que a competência absoluta não é um limite intransponível para os poderes de que estamos tratando. O estudo da jurisprudência do Supremo Tribunal Federal e do Superior Tribunal de Justiça acerca do tema foi feito apenas

${ }^{475}$ COMPETÊNCIA. EC N. 45/2004. SENTENÇA. LEGITIMIDADE. A hipótese é de direito intertemporal quanto à aplicação da EC n. 45/2004 em ação de cobrança da contribuição sindical. Quanto a isso, é consabido que, segundo a jurisprudência do STJ e do STF, essa nova regra de competência alcança processos em curso em que, na data da entrada em vigor da referida emenda, não houvesse sentença de mérito. No caso, a Justiça estadual (de primeiro e segundo graus), mesmo não decidindo definitivamente o pedido da inicial, já se manifestou, antes da aludida entrada em vigor, a respeito da legitimidade passiva, matéria já preclusa para a autora e impassível de uma modificação em hipotético julgamento na Justiça trabalhista. Daí que essa peculiar situação determina a manutenção da competência da Justiça estadual. Há que se buscar a unidade de jurisdição apregoada pela jurisprudência do STF referente ao caso. Precedentes citados do STF: CC 7.204-1MG, DJ 2/2/2006; do STJ: CC 59.067-RS, DJ 30/4/2007. (STJ; Primeira Seção; CC 90.778-SP; rel. Min. TEORI ZAVASCKI; j. 12.3.08; 31.03.08 - fonte: www.stj.jus.br, último acesso em 09.01.10, às 18:23h).

${ }^{476}$ CONFLITO DE COMPETÊNCIA. JUSTIÇA DO TRABALHO E JUSTIÇA COMUM. MANDADO DE SEGURANÇA PLEITEANDO DIREITOS RELATIVOS A VÍNCULO CELETISTA. EXAME DO MÉRITO PELA JUSTIÇA COMUM ANTES DA ENTRADA EM VIGOR DA EC 45/2004. ANULAÇÃO DO DECISUM PELO TRIBUNAL DE JUSTIÇA. PROLAÇÃO DE NOVA SENTENÇA PELA JUSTIÇA DO TRABALHO APÓS A VIGÊNCIA DA EC 45/2004. PRINCÍPIOS DA EFETIVIDADE E INSTRUMENTALIDADE DO PROCESSO. COMPETÊNCIA DO TRIBUNAL REGIONAL DO TRABALHO PARA CONHECER DO RECURSO ORDINÁRIO. 1. Em face do advento da Emenda Constitucional 45, de 31.12.2004, a competência para conhecer das ações oriundas da relação de trabalho, abrangidos entes de Direito Público externo e da Administração Pública Direta e Indireta da União, dos Estados, do Distrito Federal e dos Municípios, passou a ser da Justiça do Trabalho. 2. Essa modificação de competência, no entanto, somente atinge os processos que já se encontravam em trâmite na Justiça Estadual, se ainda pendente de julgamento de mérito; após proferida a sentença de mérito, o feito deve prosseguir na jurisdição que originalmente o apreciou, até seu trânsito em julgado e posterior execução. 3. Ocorre que, apesar da validade da sentença exarada pelo Juiz de Direito, concedendo a segurança, o Tribunal de Justiça do Estado de São Paulo não conheceu dos recursos oficial e voluntário, determinando a anulação de todos os atos decisórios proferidos no processo e a remessa para a Justiça do Trabalho, que proferiu novo decisum. 4. Não se pode dar primazia ao formalismo em detrimento da efetividade do processo; o mero apego à formalidade não pode levar o Judiciário a tomar decisões de escassa utilidade. Se, nesse ponto da discussão, já foi proferida nova sentença pela Justiça Laboral, após a entrada em vigor de norma constitucional que lhe atribuiu competência para tanto, não haveria o menor sentido e razoabilidade em prolongar mais ainda o deslinde da controvérsia, remetendo a discussão mais uma vez para a Justiça comum. 5. Conflito de Competência conhecido para declarar válida a sentença exarada pelo Juízo da 2a. Vara do Trabalho de Ribeirão Preto/SP, subsistindo, consequentemente, a competência recursal do TRT da 15a. Região, o suscitante (STJ; Terceira Seção; CC 101341/SP; rel. Min. NAPOLEÃO NUNES MAIA FILHO; j. 27.05.09; DJe 09.06.09 - fonte: www.stj.jus.br, último acesso em 09.01.10, às 18:23h). 
para comprovar que o problema não é novo, e a solução proposta não deve causar espanto.

De nossa parte, entendemos que a competência absoluta não pode servir de limite intransponível para os poderes do juiz relativos ao direito intertemporal, mas impõe uma justificativa mais forte para sua utilização e maior cautela no momento de aplicá-la.

As razões de interesse público na forma mais eficiente de estruturação dos órgãos da jurisdição são bastante relevantes, mas não impedem que, em casos excepcionais, a aplicação imediata da lei seja ainda mais prejudicial para o sistema.

No exemplo que citamos no início deste Capítulo, bem como no do julgamento do Conflito de Competência e 101341/SP, encontram-se situações em que o prejuízo suportado pela imediata aplicação da lei seria superior aos que poderiam advir com a concessão de poderes para o juiz afastála.

O que se tem, portanto, em matéria de competência absoluta, é que as justificativas para a não aplicação imediata da lei deverão ser mais fortes do que em outros casos. O limite imposto pela finalidade do ato é maior, mas não absoluto.

Para evitar o risco de insegurança relativo à instabilidade de todos os atos decisórios praticados após o afastamento da incidência imediata da lei, é de extrema importância que, antes de adotá-la o juiz submeta sua possível decisão ao crivo das partes, a fim de munir-se de um número maior de elementos para embasar o seu convencimento. Deverá, ademais, fundamentar de maneira bastante detalhada quais as peculiaridades do caso que lhe permitem agir dessa forma, esclarecendo quais os possíveis prejuízos que podem ocorrer para a justa solução do litígio se ele assim não o fizer. 
Agindo dessa maneira, a questão relativa à competência do juízo poderá ser exaustivamente debatida em todas as instâncias necessárias, o que diminui sensivelmente o risco de instabilidade da decisão ${ }^{477}$. Mesmo que a parte não a impugne, o Tribunal tomará conhecimento dela e poderá anular a sentença ou declinar da competência caso entenda injustificada a medida adotada pelo juiz.

Deve-se levar em consideração, por outro lado, que a possibilidade ora aventada não trará efeitos colaterais para o sistema de organização judiciária, porque não estamos vislumbrando a hipótese de o juiz se atribuir uma competência livremente. Nos casos de que estamos falando a lei já havia atribuído essa competência ao juiz. Ao conferir ultratividade à lei antiga ele não cria uma divisão nova de competências, mas apenas deixa de adotar uma limitação imposta pela lei, por entender que o objetivo da norma ao ditá-la não será alcançado no caso concreto.

A questão da competência ou da incompetência do juízo não pode ser analisada exclusivamente do ponto de vista do interesse da jurisdição na melhor organização dos seus órgãos jurisdicionais, porque ela tem um ingrediente a mais, que é o fato de tratar-se de uma alteração de competência. Com isso, os argumentos referentes à maior especialização dos juízes ${ }^{478}$ perdem força, eis que essa já existia, pois os juízes anteriores estavam acostumados com o tratamento da matéria.

\footnotetext{
${ }^{477}$ Não é demais frisar que a existência de julgados do Superior Tribunal de Justiça e do Supremo Tribunal Federal 'relativizando' o princípio da eficácia imediata da lei processual que rege a competência absoluta serve de apoio para a estabilidade dessa decisão.

${ }^{478}$ Das lições de DINAMARCO, Instituições..., vol. I, p. 367, verifica-se que "pelo aspecto técnicooperacional, a instituição de organismos e órgãos especializados traz em si a intenção de permitir que, graças à especialização em certas matérias, os juízes consigam maior agilidade, conhecimentos mais profundos e sensibilidade mais aguçada para as causas que lhes competem. Isso sucede não só na especialização de Justiças mediante as normas constitucionais sobre cada uma delas e sua competência de jurisdição (matéria trabalhista, eleitoral etc.), como também na instituição de varas especializadas (criminais, cíveis, da família, registros públicos etc.), na repartição de competências entre Tribunais de Justiça e de Alçada e até mesmo na distribuição interna de competência entre órgãos fracionários de um mesmo tribunal - como acontece com as três seções em que se divide o Superior Tribunal de Justiça (direito público, direito privado e direito penal)”.
} 


\section{Capítulo IX - Situações jurídicas processuais}

\subsection{Situações jurídicas versus direitos subjetivos}

A concepção das situações jurídicas surgiu como uma forma de oposição a uma visão subjetivista do direito.

Em sua obra Droit subjectifs et situations juridiques ROUBIER traça uma evolução histórica da regulamentação da sociedade, demonstrando que nos primórdios as regras jurídicas tinham caráter preponderantemente disciplinar, sem tratar diretamente de direitos subjetivos e situações jurídicas $^{479}$.

O direito romano, segundo o autor, tratava o direito privado sob um aspecto eminentemente contencioso. A base do direito (ciência jurídica) não eram os direitos subjetivos (jus) mas de as ações em justiça (actio $)^{480}$, pelas quais os cidadãos pediam a proteção de situações que poderiam ser tuteladas tanto em função da existência de uma regra jurídica (système des actions de la loi), como por uma fórmula criada pelos pretores (système de droit prétorien).

Prossegue o Professor de Lyon na sua linha do tempo chegando ao período do Renascimento, época em que aparece a idéia de direitos subjetivos. Eles eram entendidos como prerrogativas preciosas para os indivíduos e geradores de segurança, porque garantidos por proteção judiciária. $\mathrm{O}$ pensamento em torno dos direitos individuais ganha força e influencia os juristas dos séculos XVII e XVIII que passam a defender a idéia de direitos naturais. O apogeu do regime dos direitos ocorre no final do século XVIII, com a afirmação dos Direitos dos homens.

\footnotetext{
${ }^{479}$ Droits subjectifs et situations juridiques, pp. 5-9.

${ }^{480}$ A análise histórica feita por ROUBIER é assumidamente resumida (p. 7), tendo ele deixado a cargo dos historiadores do direito um tratamento mais detalhado sobre o tema. Ele também não se aprofunda no conteúdo da actio para os romanos, o que explica sua afirmação simplificada do fenômeno, distante do pensamento dos romanistas alemães WINDSCHEID e MUTTER (v. DINAMARCO, Fundamentos..., tomo I, n. 13).
} 
Posteriormente advém o período da revolução industrial, que acarreta o aumento de problemas sociais decorrentes do crescimento do proletariado. Nesse contexto a visão estritamente individual do direito perde força e a análise dos direitos do homem passa a ser entendida em conjunto com os seus deveres. Surgem, então, as teorias objetivistas que propugnam pelo abandono da concepção dos direitos subjetivos e sua substituição pela noção de situação jurídica. A idéia de direitos naturais é abandonada e ganha relevo a análise das posições jurídicas criadas pela lei ${ }^{481}$.

Desse breve resumo histórico pode-se notar que a análise das situações jurídicas surgiu como uma oposição à uma concepção individualista do direito, centrada demasiadamente nos direitos subjetivos.

Conforme analisamos no capítulo IV, nosso sistema sofre influência das duas correntes. Distanciando-se um pouco da análise específica do direito intertemporal é possível verificar que a Constituição cria uma série de garantias individuais para os cidadãos, que tanto podem ser entendidas num contexto social (erradicação da pobreza, igualdade, proteções contra abusos por parte do poder) como individualista (proteção da vida, da liberdade, da propriedade).

Dentro do sistema de direito intertemporal tem-se que, tradicionalmente, é conferida proteção constitucional aos direitos subjetivos. As situações jurídicas são protegidas no âmbito da legislação ordinária (à exceção de algumas áreas específicas do direito em que a irretroatividade da lei é tratada na Constituição, como no direito tributário).

Retomadas essas noções, fica fácil compreender que a situação jurídica terá importância para o direito pátrio exatamente onde ela não

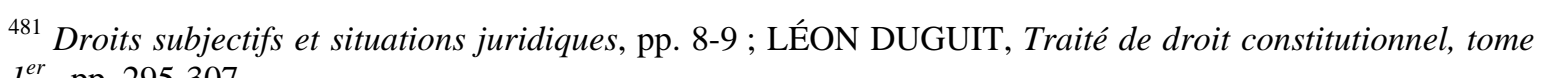
$1^{\text {er }}$., pp. 295-307. 
coincidir com os direitos adquiridos ${ }^{482}$. Por outro lado, ao estudarmos a doutrina estrangeira, devemos nos distanciar dos conteúdos ideológicos que explicam as situações jurídicas em oposição aos direitos subjetivos, dado que nosso sistema não abandonou a concepção subjetivista de proteção dos direitos adquiridos ${ }^{483}$.

\subsection{Situações jurídicas - noções gerais}

A idéia de situação, segundo ensina JOSÉ CASTAN TOBEÑAS, foi desenvolvida inicialmente pelos filósofos existencialistas do século XIX conjuntamente com a idéia de existência e detinha um caráter eminentemente individualista. O catedrático espanhol assim resumiu a tese de LUÑO PEÑA sobre a posição central da situação dentro da filosofia existencialista: "experiencia de la propria existencia, inserta en el mundo y encarnada en una situación" ${ }^{484}$.

Retornando para a ciência jurídica, tem-se que, na Alemanha, o conceito foi estudado por KOHLER, que, resumidamente o definiu como um elemento ou uma etapa do nascimento ou do desenvolvimento do direito $^{485}$. O conceito é bastante genérico e refere-se tanto a um requisito para a constituição de um direito (e. g., a capacidade) como a uma etapa de sua constituição (e. g., a instituição de um legatário na sucessão testamentária) ${ }^{486}$.

\footnotetext{
${ }^{482}$ Não nos parece que essa concepção seja demasiadamente individualista e distante dos objetivos sociais da Constituição Cidadã. A proteção aos direitos individuais no direito intertemporal se faz por uma questão de segurança da sociedade contra arbítrios do legislador, não somente do indivíduo. De se notar, ainda, que os direitos adquiridos poderão ser atingidos, em caráter excepcional, nos casos de supressão da categoria de direitos, quando esses se tornarem contrários aos valores protegidos pela Constituição. Isso permite um equilíbrio entre os interesses que se colocam em conflito no momento de decidir sobre proteger ou não determinadas situações que, em tese, são contrárias ao interesse da coletividade.

${ }^{483}$ Somente os conteúdos ideológicos, não as explicações que diferenciam os fenômenos, porque isso significaria a negação da teoria. O cuidado deve ser tomado para evitar usar o conceito de situações jurídicas a fim de negar a utilidade do conceito de direitos subjetivos.

${ }^{484}$ Situaciones juridicas subjetivas, p. 45.

${ }^{485}$ V. GOLDSCHMIDT, Princípios..., p. 47; LUDWIG ENNECCERUS, Tratado de derecho civil, tomoI, vol. I, p. 321 e JOSÉ CASTAN TOBENÃS, Situaciones..., pp. 45-46.

${ }^{486}$ A generalidade do conceito não passou despercebida por ENNECCERUS, Tratado..., p. 321, que teceu o seguinte comentário: "Así, pues, el concepto de la situación jurídica se halla muy lejos de ser aprovechable jurídicamente. No es exacto en modo alguno que sean heredables las situaciones jurídicas en tanto se refieran al patrimonio (poder de representación, poder situación del instituído en el testamento de una pessoa aún en vida), ni tampoco lo es el que todas las situaciones jurídicas puedan ser objeto de impugnación. De todos modos no es improprio hablar de situación o posición jurídica (posición del capaz de obrar, situación jurídica del usucapiente, condicio usucapiendi). Únicamente conviene guardarse de
} 
CARNELUTTI explicou o conceito mediante a análise das relações jurídicas. O mestre italiano observou a existência de diversas espécies de poder e de dever que se explicam através de combinações - faculdade-ônus; faculdade-obrigação; direito subjetivo-submissão etc.-, algumas das quais implicam em combinações necessárias ${ }^{487}$ (para que haja um direito subjetivo é necessário que lhe corresponda uma submissão) e outras, combinações em que cada uma de suas espécies pode ou não se encontrar - a faculdade pode subsistir sem que haja um ônus correspondente a ela, por exemplo. A partir daí o autor entendeu que as relações jurídicas se reservam para os grupos fundamentais (em que há uma combinação constante) e denominou-a de "a correlação necessária entre o poder e o dever e entre as espécies isoladas de um e de outro"488.

As situações jurídicas, por sua vez, corresponderiam às manifestações estáticas desse fenômeno, ou seja, a cada uma das manifestações isoladas do poder (posições jurídicas ativas) e do dever (posições jurídicas passivas) dentro de uma relação jurídica ${ }^{489}$.

Essas concepções das situações jurídicas não foram criadas para estudo específico do direito intertemporal, mas é necessário conhecê-las para que se possa, posteriormente, compreender os problemas do conceito na doutrina processual.

extraer consecuencias determinadas de todos estos aspectos jurídicos imaginables (con inclusión de los derechos también)".

${ }^{487}$ Teoría general del derecho, pp. 193-194. Essas combinações necessárias dividem-se em três grupos: faculdade-obrigação; direito subjetivo submissãoe poder-submissão (p. 194).

${ }^{488}$ Teoría..., p. 194. Um pouco mais adiante, esclareceu que: “a relação jurídica se explica como um conflito de interesses, e o efeito da regulamentação como uma atribuição aos interessados de um poder e de um dever" (p. 195).

${ }^{489}$ Teoría..., p. 196. Os conceitos de poder e dever resumem os elementos físicos, econômicos e psicológicos da situação. Para compreender melhor o pensamento do autor, é necessário ler também suas lições sobre o tema constantes do seu Sistema de direito processual civil. Nessa obra, o autor esclarece que as situações jurídicas correspondem aos interesses juridicamente protegidos ou juridicamente subordinados, sendo, portanto, elemento da relação, que se compõe de duas situações combinadas (vol. I, cap. 1º, n. 11). 
Em que pese ser um dos núcleos do direito intertemporal para os objetivistas ${ }^{490}$, a verdade é que eles não forneceram um conceito preciso do fenômeno, tendo-os delimitado primordialmente através de exemplos práticos.

DUGUIT, por exemplo, primeiramente desenvolveu sua crítica ao conceito de direitos subjetivos procurando demonstrar sua inutilidade face a uma visão enfocada no direito objetivo. Feito isso, observou que, apesar de não haver sustentação para o conceito de direito subjetivo, deve-se considerar que, "sob condições determinadas pelo direito objetivo, algumas vias jurídicas são abertas com o fim de garantir aos indivíduos determinadas vantagens para reprimir determinados comportamentos. Desses indivíduos nós dizemos que se encontram em uma situação jurídica"491.

Vê-se que o Professor da Universidade de Bordeaux optou por explicar o fenômeno, sem conceituá-lo. Nas páginas que se seguiram foram feitas as distinções entre as situações jurídicas objetivas, que derivam diretamente da norma jurídica e, como tal, são regulamentadas de forma geral e permanente. Suas características principais são a oponibilidade a todos e duração até que uma lei as revogue $\mathrm{e}^{492}$.

Já as situações jurídicas subjetivas são especiais e momentâneas. Especiais, porque se dirigem a um grupo específico de pessoas e momentâneas, porque desaparecem sem deixar rastros a partir do momento em que é adimplido o comportamento cuja proteção é assegurada à parte interessada ${ }^{493}$.

\footnotetext{
490 JOSÉ CASTAN TOBEÑAS demonstra um pouco de curiosidade no fato de uma idéia tão ligada ao individualismo na filosofia existencialista (situação) ter sido utilizada na ciência jurídica como bandeira de ataque ao subjetivismo (Situaciones..., p. 45).

${ }^{491}$ Traitè de droit constitutionel, tome 1er., p. 307.

${ }^{492}$ Exemplo citado pelo autor é a possibilidade de os homens maiores de 21 anos votarem. Por aplicação direta da lei, todos os franceses nessa condição se tornam eleitores. Ninguém poderá impedi-los de votar, o que demonstra o caráter geral da situação, pois ela é oponível a todos. Por outro lado, ela é permanente, porque não se esgota com o exercício do voto, tendo duração enquanto a lei conferir-lhe proteção (Traitè..., $t$. 1er., p. 309).

493 Traitè..., t. 1er., pp. 312-313.
} 
Nas suas principais obras de direito intertemporal ROUBIER deixou de se aprofundar sobre o conceito de situações jurídicas, explicando apenas que a expressão situação jurídica foi escolhida para servir como a mais vasta de todas $^{494}$.

Foi em obra posterior (Droits subjectifs et situations juridiques) que o Professor francês se debruçou sobre o tema, sem, contudo, fornecer-Ihe um conceito preciso.

Sua primeira preocupação foi a de distinguir as regras jurídicas das situações jurídicas. Tanto umas como as outras se beneficiam do poder público que lhes confere, principalmente pela via das autoridades judiciárias, sua sanção. Não é, pois, o caráter imperativo que as difere, porque ambas são imperativas e é isso que implica o qualificativo "jurídico" que elas têm em comum.

O que as diferencia é que, enquanto as regras jurídicas são gerais e abstratas, as situações detêm um caráter individual e concreto. Justamente por não deterem essa característica geral e abstrata, tanto os atos jurídicos privados como as decisões administrativas e os julgamentos dos tribunais não podem ser considerados regras jurídicas ${ }^{495}$.

Feita essa distinção o autor esclareceu que as situações jurídicas não podem ser estabelecidas senão sobre uma base que esteja em conformidade com as regras jurídicas, mesmo quando são criadas por fatos materiais (como um acidente de trânsito que gera um direito de reparação do dano) é a lei que regula suas condições de existência e seus efeitos ${ }^{496}$.

\footnotetext{
${ }^{494}$ Le droit transitoire, p. 181. Em seguida afirma o autor que: "nous le jugeons supérieur au terme de droit acquis, en ce qu'il n'a pas un caractère subjectif et qu'il peut s'appliquer à des situations comme celles de mineur, d'interdit, de prodigue; nous le jugeons également supérieur à celui de rapport juridique (Rechtsverhältniss), si fréquemment employé dans la science contemporaine, et qui implique une relation directe entre deux personnes, alors que la situation juridique peut être unilatérale et opposable à toute personne, quelle qu'elle soit ". A mesma passagem pode ser lida na obra Les conflits des lois dans le temps, tome $1^{\text {er }}$., p. 378.

${ }^{495}$ Droits subjectifs..., p. 2. A afirmação do autor seria colocada em xeque hoje em dia com relação a alguns atos das cortes superiores que, ao suprirem lacunas da lei, exercem efetivamente uma atividade criadora do direito de forma geral e abstrata.

${ }^{496}$ Droits subjectifs..., p. 4.
} 
Posteriormente ele traça uma linha histórica da evolução do pensamento jurídico, para concluir pelo abandono da concepção subjetivista do direito. A sociedade moderna não pode se preocupar apenas com os direitos, mas com os direitos e deveres. Numa mesma situação jurídica os próprios titulares de direitos também têm deveres para que possam preservá-los. Assim, é o entrecruzamento de direitos e deveres que caracteriza a organização jurídica ${ }^{497}$. Após essas explicações pondera que "a situação jurídica se nos apresenta como constituindo um complexo de direitos e deveres; logo, ela é uma posição infinitamente mais freqüente que aquela de direitos existente no estado de prerrogativas franqueadas, ou de deveres aos quais não correspondam nenhuma vantagem". ${ }^{498} \mathrm{E}$, para concluir, observou a existência de uma distinção fundamental entre as situações jurídicas, qual seja, em algumas o elemento da prerrogativa ou da vantagem aparece em primeiro plano para o titular da situação jurídica. Essas são as situações jurídicas subjetivas, as quais tendem a criar mais direitos do que deveres. Em outras, o elementos dever é a carga predominante. Essas são as situações jurídicas objetivas, às quais tendem a reconhecer mais deveres do que direitos ${ }^{499}$.

As últimas colocações sobre o complexo de entrecruzamento de direitos e deveres podem passar a impressão de que as situações jurídicas têm ligação com a idéia de institutos jurídicos ${ }^{500}$. De fato, na maior parte dos exemplos estudados por ROUBIER (matrimônio, sucessão, usucapião etc.) têm-se a associação das situações jurídicas com figuras mais complexas que detêm para si um regramento próprio mais detalhado. Todavia, deve-se descartar essa idéia.

ROUBIER buscou claramente explicar o fenômeno da retroatividade mediante a análise do modo como a lei se projeta fora do mundo

\footnotetext{
${ }^{497}$ Droits subjectifs..., pp. 45 e ss..

${ }^{498}$ Droits subjectifs..., p. 52.

499 Droits subjectifs..., pp. 53-54.

${ }^{500}$ A Academia Brasileira de Letras Jurídicas (Dicionário jurídico) assim define o termo instituto jurídico: "Diz-se de cada uma das entidades componentes do cosmo jurídico, com disciplina própria. Assim, instituto do matrimônio, instituto da decadência, instituto do contrato etc.”. Para DE PLÁCIDO E SILVA, Vocabulário jurídico, vol. II, D - I: "instituto na terminologia jurídica, é a expressão usada para designar o conjunto de regras e princípios que regem certas entidades ou certas situações de direito”.
} 
abstrato. Sua preocupação, expressamente assumida, foi a de conferir o conceito mais amplo possível para as situações jurídicas, de modo que elas pudessem se aplicar a todos os fatos e acontecimentos concretos por ela atingidos ${ }^{501}$. Diante disso, a melhor compreensão da sua doutrina não poderá restringir o conceito de situação jurídica apenas para abranger os chamados institutos jurídicos.

Corroboram com essa afirmação as palavras de SEBASTIANO CASSARINO: "è prevalsa però in seguito la tendenza ad intendere per situazione giuridica il modo di essere di un soggetto rispetto ad una norma, e si son fatti rientrare sotto tale nozione $i$ diritti soggettivi e i doveri, i poteri, gli oneri le soggezioni gli interessi legitimi, gli status, le qualità ecc." ${ }^{502}$.

\subsection{Situações jurídicas processuais - colocação do problemas}

A identificação das situações jurídicas no direito processual ganha um relevo especial por dois aspectos distintos. O primeiro diz respeito à terminologia. A ciência processual conta com utilizações particulares do termo, que impõem a necessidade de compreensão de qual a sua concepção adequada para o direito processual intertemporal.

Além disso, a complexidade da relação jurídica processual, composta por uma série de atos e fenômenos ordenados para um mesmo fim, muitas vezes torna difícil a identificação do modo como deve ser entendido o fato abstratamente regulado pela nova norma: trata-se de uma situação jurídica nova?

\footnotetext{
${ }^{501}$ Essa amplitude pode ser verificada no modo como os léxicos franceses definem as situations juridiques: "On parle de situation juridique pour exprimer la situation dans laquelle se trouve une personne vis-à-vis des autres sujets de droit, sur les fondament des regles de droit" (RAYMOND GUILLIEN et JEAN VINCENT, Lexique des termes juridiques). Apesar da tautologia da definição, que utiliza o termo situação para explicá-la, é possível extrair dos exemplos citados para explicar sua aplicação (acidente; morte; estado pessoal; ato jurídico) que não existe restrição em função da complexidade do fenômeno, para que se possa defini-la como uma situação jurídica ou não.

${ }^{502}$ Le situazioni giuridiche e l'oggetto della giurisdizione amministrativa, p. 1. O autor acolhe a definição aceita pela maioria em respeito ao cânone que impõe que se evite inovar em termos de linguagem para não gerar incerteza quanto aos conceitos, mas, por entender excessivamente restritiva a definição, acrescenta que ela deve excluir a qualidade dos fatos, dos objetos etc. (pp. 1-2).
} 
De um efeito de uma situação jurídica já constituída, ou de uma forma de influenciar na constituição e extinção de outras situações jurídicas?

Estudaremos cada um desses problemas em tópico separado, para facilitar o desenvolvimento das idéias que lhes correspondem.

\subsubsection{Situações jurídicas processuais e suas diferentes acepções}

Quando um processualista pensa no termo situação jurídica uma primeira idéia lhe vem à mente: a explicação da natureza do processo feita por GOLDSCHMIDT.

O autor alemão, partindo da noção de KOHLER que explicou as situações jurídicas como uma etapa do nascimento dos direitos, considerou que o processo tinha natureza jurídica de situação jurídica, ${ }^{503}$ porque dentro da dinâmica do processo os direitos subjetivos somente teriam relevância após o seu reconhecimento pelo juiz ${ }^{504}$. Além de considerar o processo de maneira global uma situação jurídica, o autor pontuou que as expectativas de uma decisão favorável bem como as perspectivas de uma sentença desfavorável que decorrem das posições jurídicas ocupadas pelas partes no processo também constituem em si situações jurídicas ${ }^{505}$.

O elemento essencial para a compreensão do fenômeno situação na concepção de GOLDSCHMIDT é a relação entre uma determinada

\footnotetext{
${ }^{503}$ Princípios..., pp. 43-52.

504 “Assim sendo, quando o direito for considerado como meio do arbítrio judicial, todos os nexos jurídicos têm de consistir em uma relação com a sentença esperada, ou seja, que se apóiam na expectativa da conduta do juiz, do partido que tomará e, em última análise, da sentença que prolatar” (Princípios..., p. 43).

${ }^{505}$ Princípios..., p. 47. Na obra Problemas jurídicos y políticos del proceso penal, p. 47, GOLDSCHMIDT explicita bem esse entendimento, afirmando que: "Todas las categorías processales estabelecidas anteriormente representan situaciones jurídicas, lo que quiere decir estado de una persona con respecto a su derecho bajo el punto de vista de la sentencia judicial que se espera con arreglo a las leyes”.
} 
posição de um sujeito com o direito material. A situação jurídica qualifica-se como tal por ser um elemento ou um estágio na formação do direito ${ }^{506}$.

Como vimos CARNELUTTI observou o fenômeno de maneira um pouco distinta, relacionando as situações jurídicas com as posições isoladas que uma pessoa ocupa dentro de uma relação jurídica. Diferentemente da relação jurídica, que engloba a posição de dois ou mais sujeitos frente a um objeto, aquelas se refletem somente na posição de uma das partes da relação jurídica. Daí porque consistiria numa posição de uma pessoa em face a um objeto $^{507}$.

Das construções de CARNELUTTI e de GOLDSCHMIDT pode-se notar uma semelhança muito grande com relação à descrição do fenômeno, embora suas explicações sejam de todo distintas. Tanto em uma como em outra as posições jurídicas dos sujeitos processuais são entendidas como situações jurídicas. Suas explicações é que caminham para lados opostos.

A compreensão das situações jurídicas como posições ocupadas pelas partes dentro da relação jurídica é a mais aceita pela doutrina ${ }^{508}$ e, como visto, resume-se na compreensão da posição do sujeito frente a um comportamento. Por isso é que tais situações são caracterizadas como ônus, poderes, deveres, faculdades ou obrigações.

Feitas essas explicações, deve-se sublinhar que não é esse o conceito que vigora no direito intertemporal. As situações jurídicas, nessa disciplina, detêm um conceito muito mais amplo que engloba a relação entre um fato com uma norma. A situação jurídica processual, entendida do ponto de vista do direito intertemporal, tanto pode referir-se a uma posição isolada de um dos

\footnotetext{
${ }^{506}$ A propósito, anota JOSÉ CASTAN TOBEÑAS, Situaciones..., p. 46 que GOLDSCHMIDT levou para a esfera processual a noção de KOHLER sobre as situações jurídicas.

${ }^{507}$ PEDRO DA SILVA DINAMARCO, Ônus processuais: limites à aplicação das conseqüências previstas para o seu não-cumprimento, pp. 9-11, compreendeu as situações jurídicas como posições que determinadas pessoas ocupam em relação a um objeto. Esse objeto, no processo, é uma conduta, jamais um bem, tal qual nas relações substanciais (p. 12).

${ }^{508}$ Essa é a terminologia usada por DINAMARCO, Instituições..., vol. II, p. 201; MARCO TULLIO ZANZUCCHI, Diritto processuale civile, vol. I, p. 73; ELIO FAZZALARI, Note in tema..., pp. 109-100 e ENRIQUE VÉSCOVI, Teoría general del proceso, p. 95.
} 
sujeitos, como a uma relação entre ambos, com direitos e deveres para cada lado. O que importa para o direito intertemporal é saber como determinado fato, para o qual a lei ditava conseqüências, era regido no momento em que ocorreu.

Pensemos assim na situação surgida com a prática de um ato de litigância de má-fé (faltar deliberadamente com a verdade). A prática do ato gera uma relação entre autor e réu na qual um será titular de um direito (ofendido) e o outro de uma obrigação (ofensor). Para cobrar o valor do dano o ofendido terá que formular um pedido para o juiz, que, por sua vez não poderá impor uma condenação além dos limites da lei. Todos os elementos dessa relação são considerados como integrantes da mesma situação jurídica regrada pela lei, não somente as posições isoladas de cada uma das partes.

A fim de saber se ela é retroativa, deve-se entender o modo como eram disciplinadas todas as conseqüências jurídicas do fato no momento em que ele foi praticado. A posição isolada de cada um dos sujeitos processuais nesse momento não será útil para saber se a lei é retroativa ou não.

Se uma lei posterior suprimir das hipóteses de condenação por litigância de má-fé a prática de ato consistente em faltar com a verdade, essa lei atingirá o momento de formação da situação jurídica e, por isso, será retroativa $^{509}$. Por outro lado, se ela reduzir o limite máximo de condenação não poderá ser aplicada aos fatos passados que tenham produzido esse efeito imediatamente, porque, além de respeitar os momentos de constituição e extinção da situação jurídica, ela deve preservar os efeitos produzidos antes de sua entrada em vigor ${ }^{510}$.

\footnotetext{
509 “Lorsqu'il s'agit de déterminer comment se constitue (ou s'éteint) une situation juridique, ne peut prendre en considération des faits antérieurs à son entrée en viguer sans être rétroative; à cet égard, il faut mettre sur le même pied la loi qui déciderait que des faits, qui avaient produit la constitution (ou l'extinction) d'une situation juridique sous la loi précédente, n'avaient pas eu ce pouvoir, et la loi qui déciderait que des faits, qui n'avaient pas produit la constitution (ou l'extinction) d'une situation juridique sous la loi précédente, avaient eu, au contraire, ce pouvoir ” (ROUBIER, Le droit transitoire, p. 182).

${ }_{510}$ A propósito da relação entre fato e norma para identificação do fenômeno da retroatividade, é bastante elucidativa a seguinte passagem de CHIRONI e ABELLO: "La legge dà vita e valor giuridico all'atto che sotto il suo impero venne costituito in osservanza delle sue prescrizioni. Basta ancor qui argomentare dal concetto fondamental dell'obbligatorietà per dedurne che il fatto compiuto in conformità dell'ordinamento che lo regola, è giuridicamente efficace e deve essere perciò tutelato in quel modo e nei termini che la legge consente" (Trattato di diritto civile italiano, vol. I, p. 81).
} 
Fica claro, portanto, que o conceito tradicional de situação jurídica processual deve ser abandonado no momento de aferição da eficácia temporal de uma lei processual.

\subsubsection{Situações jurídicas processuais e complexidade da relação jurídica processual}

Existe, ainda, mais um cuidado que o aplicador da norma deve ter no momento de identificar seu caráter retroativo: a compreensão do modo como a lei se dirige aos mais diversos fatos jurídicos que podem dar origens a situações jurídicas processuais ${ }^{511}$.

Tradicionalmente a doutrina brasileira entende que no processo se desenvolve uma única relação jurídica ${ }^{512}$ entre as partes e o juiz que caminha até a outorga da prestação jurisdicional.

Essa relação consiste no desenvolvimento da disputa de autor e réu para convencer o juiz a conferir-lhes a tutela jurisdicional. Para tanto, farão cada qual os seus pedidos, levarão a ele suas alegações e buscarão comprová-las.

Uma demanda pode ser analisada em diversos graus de aproximação para o fim de definir a existência de situações jurídicas. Vista de longe, a demanda é em si uma situação jurídica. Sua propositura consiste em um fato regrado por uma norma jurídica. Se uma lei impuser um determinado requisito para a constituição dessa situação jurídica (exigir, por exemplo, a representação por dois advogados ao invés de um) ela não poderá atingir o ato

\footnotetext{
${ }^{511}$ Doravante quando falarmos de situações jurídicas processuais estaremos nos referindo a sua acepção tirada da doutrina do direito intertemporal.

${ }^{512}$ Nesse sentido, v. GRINOVER-CINTRA-DINAMARCO, Teoria geral do processo, item 175, OVÍDIO A. BAPTISTA DA SILVA e FÁBIO GOMES, Teoria geral do processo civil , pp. 32-35 e MARCUS ORIONE GONÇALVES CORREIA, Teoria geral do processo, pp. 121-123.
} 
de constituição da demanda e considerá-lo viciado, porque, fazendo-o, será retroativa.

Aproximando um pouco nossa visão, vemos que, de maneira não muito nítida, o processo é dividido em algumas fases processuais. Sempre que a lei se referir a alguma delas para lhe dar um tratamento específico, poderá ser considerada como situação jurídica. Assim, por exemplo, se uma lei disser que durante a fase postulatória as partes podem livremente alterar o objeto da demanda e ditar que essa fase se encerra com a audiência preliminar, lei posterior que imponha o término da fase postulatória após a apresentação de réplica não poderá ser aplicada aos processos pendentes em respeito ao princípio da irretroatividade ${ }^{513}$.

De maneira ainda mais próxima vemos um número bastante variado de posições jurídicas e atos processuais, que também podem ser igualmente considerados situações jurídicas, por deterem uma disciplina legal própria.

É interessante notar, ainda, que muitos desses atos produzem efeitos durante um período distinto de tempo, sendo bastante comum que eles gerem a abertura de uma nova etapa no curso do procedimento, durante a qual outros atos serão produzidos.

Por fim, temos que incluir mais um elemento complicador nesse emaranhado de situações jurídicas. Muitas delas estão interligadas a outras de tal forma que eventualmente uma alteração que a lei venha a lhes conferir pode afetar os momentos dinâmicos daquelas situações que lhe são conexas.

Traçadas essas linhas gerais sobre o modo como podem ser observadas as situações jurídicas processuais é possível dividir a compreensão

${ }^{513}$ É importante deixar marcado desde já que, para que uma fase processual possa ser considerada uma situação jurídica no processo, a lei tem que ditar conseqüências para ela. Não basta afirmar que a doutrina divide o processo em fases e a lei alterou a sua forma de constituição (ou de extinção). 
da eficácia temporal da norma em dois momentos: (i) identificação da situação jurídica processual e do modo como a lei a atinge e (ii) análise de possíveis entrecruzamentos dessa situação com outras situações processuais, para verificação se daí resultará alguma afetação aos momentos dinâmicos dessas.

É importante ressaltar, mais uma vez, que para se cumprir a primeira missão deve-se abandonar o hábito de procurar identificar a fase em que o processo se encontra. Essa fase somente terá alguma utilidade se a lei se dirigir a ela. Caso contrário não servirá para nada.

A identificação da situação jurídica regrada pela norma deverá partir, portanto, da identificação do fato que a norma procura atingir. $\mathrm{O}$ método para se chegar a essa identificação deverá ser a comparação entre as normas antiga e nova ${ }^{514}$. Pensemos no exemplo da multa criada pelo art. 475-J do Código de Processo Civil, para explicar do que estamos falando.

Dispôs a norma que: "Caso o devedor, condenado ao pagamento de quantia certa ou já fixada em liquidação, não o efetue no prazo de (15) quinze dias, o montante da condenação será acrescido de multa no percentual de dez por cento e, a requerimento do credor e observado o disposto no art. 614, inciso II, desta Lei, expedir-se-á mandado de penhora e avaliação".

Para identificação da situação jurídica regrada por ela devemos confrontá-la com a norma anterior e indagar: o que foi criado de novo no ordenamento? A resposta será: uma multa para o não cumprimento espontâneo da sentença.

A partir dessa constatação, fica fácil perceber que sua aplicação a todos os processos pendentes após a sua entrada em vigor não acarretará qualquer retroatividade. A lei regula um determinado comportamento (não cumprir espontaneamente a obrigação de pagar fixada por uma sentença

\footnotetext{
${ }^{514}$ Segundo ensinou ROUBIER: "En effet, la première condition nécessaire pour l'existence d'un conflit de lois dans le temps fait défaut, à savoir l'opposition entre une loi ancienne et une loi nouvelle" (Le droit transitoire, pp. 208-209).
} 
judicial) e impõe-lhe uma conseqüência, aplicação de multa. Somente os comportamentos posteriores a sua entrada em vigor é que acarretarão a incidência da multa ${ }^{515}$, donde se conclui, tranquilamente, que não haverá aí nada de retroativo.

Poder-se-ia objetar com o argumento de que o trânsito em julgado da sentença se deu em momento anterior à vigência da lei, ou que a execução já havia iniciado quando a lei entrou em vigor, mas, em qualquer caso, tais argumentos seriam pouco produtivos para a compreensão do fenômeno.

Com relação ao trânsito em julgado da sentença, a nova lei alterou algum de seus momentos dinâmicos? A resposta é não. Ela sequer diz respeito à coisa julgada.

Mudando o enfoque da coisa julgada para a sentença passada em julgado, a solução permanece inalterada, mesmo se pensássemos que a nova lei conferiu um efeito novo à sentença (o que não é o melhor modo de entender o fenômeno, dado que a lei se dirige para o comportamento do executado e não para a sentença ${ }^{516}$ ). Os efeitos das situações jurídicas dizem respeito ao seu momento estático e regulam-se pela lei do tempo em que são produzidos. Assim, caso se admitida que a multa representa um efeito coercitivo conferido à decisão, a lei que se aplicar a uma sentença proferida antes de sua entrada em vigor nada terá de retroativa, desde que respeite os efeitos produzidos anteriormente à sua vigência.

O que se têm é que, mesmo considerando que a situação criada pela norma é dependente de uma situação anterior (existência da sentença

\footnotetext{
${ }^{515}$ Como a jurisprudência do Superior Tribunal de Justiça orientou-se no sentido da dispensabilidade de intimação para pagamento como requisito para a incidência da multa é conveniente, e extremamente recomendável, que essa intimação seja feita nos casos em que a condenação já tinha sido fixada antes do advento da lei, para evitar surpresas ao executado. De se louvar, a propósito, que tenha sido esse o posicionamento adotado pelo Superior Tribunal de Justiça quando passou a reconhecer a possibilidade de aplicação da multa do art. 475-J aos processos com trânsito em julgado anterior à vigência da lei ( $3^{\mathrm{a}}$ Turma; MC 14.258; rel. Min. NANCY ANDRIGHI).

${ }^{516}$ Veja-se, assim, que a multa tem natureza punitiva, conforme forte posicionamento da doutrina. V. DANIEL AMORIM ASSUMPÇÃO NEVES, Reforma do CPC, pp. 218-219, com ampla remissão aos posicioinamento doutrinários.
} 
condenatória), não há motivos para deixar de aplicar a lei nova, se essa situação constitui em si apenas um efeito da situação anterior ${ }^{517}$.

A análise do fenômeno do ponto de vista da existência de uma execução pendente não traz resultados menos frustrantes para sua compreensão. Isso porque, o dispositivo legal em análise em nada se refere à constituição ou extinção da execução. Ele não diz respeito sequer a algum efeito da pendência do processo de execução, e em nada altera a situação jurídica "processo de execução". A inserção do dispositivo em um processo de execução pendente apenas fará com que, se o executado permanecer inadimplente, sejaIhe aplicada a multa prevista na lei. Trata-se, novamente, de eficácia imediata da lei.

O problema fica mais complexo, todavia, se considerarmos uma execução pendente com embargos à execução já opostos pelo executado. Nesse caso, como os embargos detinham efeito suspensivo, a aplicação imediata da lei acarretaria, na prática, o fim da suspensividade desses, ao impor um comportamento contrário a ela.

Do ponto de vista do direito intertemporal a solução seria fria: como o direito adquirido refere-se somente aos conteúdos relacionados com o poder de exigir uma resposta do juiz (v. cap. VII, supra) a lei, em tese, poderia afetá-los, porque se dirige aos seus efeitos e não aos seus momentos dinâmicos. A constituição dos embargos permanece válida e somente sua eficácia suspensiva é que seria afetada.

Ocorre que, nesse caso específico, não parece que a solução possa partir do direito intertemporal. O dispositivo em análise não tratou da supressão de efeito suspensivo aos embargos à execução. Esse efeito suspensivo, portanto, não foi extinto pela nova lei e continua existindo. Como a

\footnotetext{
${ }^{517}$ Analisando o tema das situações dependentes em a constituição de uma altera a produção de efeitos de outra, observou ROUBIER que: "La solution ne peut être douteuse, parce que c'est une règle générale de droit que le principal emporte l'accessoire (accessorium sequitur principale). Par conséquent dans la mesure oú la constitution d'une situation juridique n'est qu'un effet immédiat et direct d'une situation principale, la loi nouvelle doit être considérée comme visant les effets de celle-ci et, par suite, elle est d'application immédiate " (Le droit transitoire, p. 216).
} 
multa do art. 475-J só é aplicável aos casos em que o comando da sentença não está com sua eficácia suspensa, resulta que ela não poderia incidir nos processos em que já tivessem embargos à execução opostos, não por uma questão de direito intertemporal, mas de não caracterização da conduta prevista na fattispecie normativa.

\subsection{Conclusão do capítulo}

Embora ROUBIER não tenha fornecido um conceito muito preciso do que vem a ser as situações jurídicas, pode-se extrair de suas lições que a utilização do termo fez-se de modo a abranger os mais diversos tipos de fatos que podem ser atingidos por uma norma. Nas situações jurídicas vislumbradas por ROUBIER o que se tem é uma relação entre um fato e uma norma.

Transpondo-se esses ensinamentos para a ciência processual, deve-se, primeiramente, tomar o cuidado de não confundir as situações jurídicas processuais, comumente identificadas pela doutrina com as posições jurídicas ocupadas pelos sujeitos processuais, com a situação jurídica a que alude ROUBIER, porque são fenômenos completamente distintos.

A análise da retroatividade da lei, segundo a doutrina de ROBIER, faz-se a partir do enfoque de como uma lei atinge as situações jurídicas no momento de sua entrada em vigor. A compreensão do fenômeno no campo processual demanda, antes de tudo, que se abandone o hábito de tentar solucionar o problema a partir da análise do modo como a lei atinge a fase processual.

Para que se possa identificar a situação jurídica processual é necessário comparar a forma como a lei antiga e a lei nova regulamentam determinado fenômeno processual, isolando as novidades contidas nessa alteração. Feito isso, deve-se indagar qual o fenômeno que está regido pela 
norma. Quando ele ocorrer no campo concreto, ter-se-á a situação jurídica, que abrange tanto a hipótese normativa, como sua conseqüência.

Explicando a questão num esquema lógico-formal não sancionista, e retomando o exemplo do art. 475-J, podemos colocá-la da seguinte forma ${ }^{518}$.

Esquema 1: (hipótese) Se devedor de quantia reconhecida judicialmente, (preceito) então tem que pagar.

Esquema 2: (hipóteses) Se não pagar, (preceito) então haverá a incidência de multa.

A hipótese 1 (norma secundária) não foi alterada pela norma. Antes da existência do art. 475-J os devedores de quantia judicialmente reconhecida também tinham o dever de pagá-las. Daí se exclui que o comportamento visado pela norma dirija-se a esse fenômeno. O comportamento tratado pela norma é o inadimplemento, dado que é para esse que ela prevê uma conseqüência nova. Feita essa identificação, pode-se entender que a concretização da hipótese abstrata prevista pela norma é que dá origem à situação jurídica, a qual corresponde tanto ao evento previsto na hipótese como às suas conseqüências. A situação criada pela inobservância do dever de adimplir a obrigação será a configuração do devedor como inadimplente sujeito a multa.

Esse é, em linhas gerais, o caminho para a identificação das situações jurídicas processuais.

Superada essa etapa, o intérprete deve dividir seus momentos em dinâmicos e estáticos a fim de compreender se a aplicação da norma acarretará ou não retroação. Sempre que a norma afetar os momentos

\footnotetext{
518 Seguindo os ensinamento de GAETANO PACE, Il diritto transitorio, pp. 142 e ss., JOSÉ EDUARDO MARTINS CARDOZO, Da retroatividade da lei, pp. 259 e ss., suas conclusões, contudo, aproximam-se mais da teoria do fatto compiutto, sem muita penetração na nossa doutrina e jurisprudência (e que não exerce influência em nossa legislação), razão pela qual deixamos de reproduzi-las para não adentrarmos em temas que fugiriam o escopo de sistematização do presente estudo.
} 
dinâmicos (de constituição ou extinção) da situação jurídica, será retroativa. Com relação ao momento estático de produção de efeitos, a norma somente será retroativa se atingir os efeitos pretéritos.

Finalmente tem-se que verificar que algumas situações jurídicas processuais estão intimamente ligadas a outras. A solução dos problemas relativos às situações jurídicas dependentes conduz à compreensão de que muitas vezes algumas situações processuais nada mais são do que efeitos de outras. Nesses casos, como a lei que atinge o momento estático das situações jurídicas tem efeito imediato, a regra geral será sua aplicação com respeito aos efeitos anteriormente produzidos.

\section{Capítulo X - Conclusões}

\subsection{Síntese das conclusões obtidas durante o trabalho}

1. No início deste estudo analisamos a evolução da doutrina do direito intertemporal e verificamos a existência de duas correntes de pensamento que partem de premissas filosóficas distintas: a corrente subjetivista, que fundamenta o sistema de direito intertemporal na proteção aos direitos adquiridos, e a corrente objetivista, que nega a utilidade desse conceito e fixa o estudo do direito intertemporal no modo como a lei pode atingir as situações jurídicas.

2. No sistema clássico de proteção aos direitos adquiridos a retroatividade da lei é entendida como uma forma de atingir os fatos pendentes no momento de sua entrada em vigor. Nos casos em que sua aplicação fere direitos adquiridos a lei é injustamente retroativa, para os demais, fala-se em retroatividade justa. 
3. Reagindo contra essa forma de pensar extremamente centrada na idéia de direitos subjetivos, os pensadores objetivistas descartaram a utilização dos direitos adquiridos para a solução de problemas afetos ao direito intertemporal e analisaram o fenômeno da retroatividade a partir do modo como a lei atinge os fatos jurídicos no momento de sua entrada em vigor. Sempre que a lei projetar-se sobre fatos ocorridos antes de sua vigência ela será retroativa, nos demais casos, fala-se em eficácia imediata da lei.

Para a compreensão dessa explicação é importante dividir as situações jurídicas em facta praeterita; facta pendentia e facta futura. A aplicação da lei para os primeiros será sempre retroativa, e para os últimos, jamais. Com relação aos facta pendentia, se a lei atingir seus momentos de constituição e extinção ou os efeitos consumados antes de sua entrada em vigor, será retroativa. Se atingir somente os efeitos futuros dessas situações não haverá retroatividade.

Outra noção de extrema importância para a compreensão da teoria objetivista é a de ultratividade (survie) da lei antiga. Em um esquema geral em que a lei não tem efeitos retroativos a regra é que ela seja aplicada imediatamente às situações pendentes. Contudo, para as situações contratuais a regra é a sobrevivência da lei em vigor no momento da celebração do contrato.

4. Na prática existe uma coincidência muito grande entre os resultados obtidos pela aplicação dessas duas teorias, quer porque a proteção aos direitos adquiridos na grande maioria dos casos impede a aplicação retroativa da lei, ou porque a ultratividade da lei para reger as situações contratuais protege uma gama elevada de situações em que sua eficácia imediata poderia ferir direitos adquiridos. Justamente no campo processual é que os resultados práticos dessas duas teorias mais se distanciam, porque o campo de incidência dos direitos adquiridos no processo é bem mais reduzido.

5. Da análise do nosso ordenamento podemos concluir que ele sofre influência das duas correntes, havendo uma proteção de ordem 
constitucional aos direitos adquiridos e outra legal que impede a aplicação retroativa da lei.

As diferenças entre a hierarquia das proteções previstas no nosso ordenamento faz com que a dirigida aos direitos adquiridos seja mais forte e somente possa ser atingida em casos extremos, cuja análise se faz mediante a aplicação do princípio da proporcionalidade. A irretroatividade da lei, por sua vez, estando prevista em lei ordinária, permite que o legislador crie leis retroativas, desde que não atente contra direitos adquiridos. Em todo caso, a lei deverá ser expressa ao afirmar esse caráter retroativo, não sendo ele presumível.

6. O estudo autônomo do direito processual civil intertemporal é justificado. Essa justificativa não decorre do caráter público das normas processuais, da complexidade da relação jurídica processual ou da sua autonomia da relação jurídica de direito material, embora essas características possam fornecer elementos para identificar a razão que permite um estudo autônomo da disciplina sob um enfoque processual.

As diferenças fundamentais que justificam a autonomia apontada são: (i) o valor da segurança jurídica no processo e (ii) a existência de uma relação jurídica diferenciada, desenvolvida de maneira triangular com nexos entre autor-juiz; réu-juiz e autor-réu, sendo muito mais constantes os dois primeiros. Em função dos menores espaços para a ocorrência de relações diretas entre as partes, bem como da participação de um terceiro sujeito que é neutro e se coloca entre os demais, resulta uma diminuição de amplitude do princípio da segurança jurídica, que passa a ter que equilibrar as necessidades das partes com as do juiz no processo.

A preservação da estabilidade de determinadas situações jurídicas passa ter valor mais relativo, o que diminui o espaço para a proteção subjetiva na esfera processual. Por outro lado, a existência de um interesse público na solução do conflito faz com que o sistema de direito intertemporal tenha que ser aplicado em consonância com os escopos da ciência processual, o 
que muitas vezes permite ao julgador afastar a eficácia imediata da lei processual em um caso concreto.

7. No campo da legislação processual encontra-se uma escassez muito grande de normas tratando da matéria, o que remete o intérprete às regras gerais do sistema, que devem ser entendidas de maneira compatibilizada com as regras e princípios próprios do direito processual.

Pode-se notar uma controvérsia na doutrina acerca da natureza da norma prevista no art. 1.211, do Código de Processo Civil, havendo quem afirme tratar-se de norma transitória aplicável somente à lei que instituiu o Código de Processo Civil e quem a entenda como uma regra geral do sistema, que prevê a eficácia imediata de toda e qualquer lei processual.

Partilhamos do segundo entendimento, embora acreditemos que a controvérsia não seja relevante, porque a aplicação imediata da lei processual está inserida no sistema, se não por força desse dispositivo, então em função da previsão contida na Lei de Introdução ao Código Civil.

8. O estudo dos modelos de sistemas de direito processual intertemporal tem importância meramente didática e deve ser utilizado com bastante cuidado, já que nenhum deles é suficiente para descrever o funcionamento do nosso sistema.

Daqueles modelos, o que mais se aproxima do nosso é o do isolamento dos atos processuais, mas ele não prevê a proteção aos direitos processuais adquiridos e não permite que o juiz exerça qualquer poder de controle sobre a eficácia temporal de uma lei processual.

9. A análise da doutrina e da jurisprudência fornece desenhos de um sistema que protege os direitos processuais adquiridos e impõe a eficácia imediata da lei, mas não explica de maneira suficiente qualquer um desses fenômenos. É possível encontrar, ainda, posicionamento doutrinário que aponta para a possibilidade do juiz exercer um poder de controle no momento de 
aplicação da lei processual, sem que essa explicação seja feita de maneira mais pormenorizada.

As grandes lacunas que se encontram no direito processual intertemporal referem-se à delimitação dos direitos processuais adquiridos; à explicação do modo como o juiz pode afastar a eficácia imediata das leis processuais e à forma de compreensão e identificação das situações jurídicas processuais.

10. Ao estudarmos os direitos processuais adquiridos concluímos que eles podem ser analisados a partir de três enfoques distintos: das relações entre as partes e o juiz; das relações entre as partes no processo; e a partir da compreensão dos institutos bifrontes.

11. O primeiro deles revela uma íntima ligação entre direitos processuais adquiridos e o direito de ação - entendido em seu caráter dúplice, que abrange também o direito de defesa, e em conformidade com as garantias do devido processo legal. Somente os poderes das partes que sejam desdobramentos diretos do poder de exigir o provimento jurisdicional é que são passíveis de aquisição e podem dar origem a direitos adquiridos.

A vinculação dos direitos adquiridos processuais com o direito de ação, entendido como um poder de exigir o provimento jurisdicional, permite afastar a possibilidade de que o descumprimento de um ônus gere um direito para a parte contrária. Por outro lado, essa compreensão delimita bastante a amplitude dos direitos processuais adquiridos, na medida em que exclui do seu campo toda matéria relativa à técnica processual que não trate das possibilidades conferidas às partes para formular demandas relativas ao seu direito material no curso do processo.

Mesmo com relação a essas demandas, o direito adquirido processual refere-se exclusivamente ao poder de exigir uma resposta, o que indica que a matéria relativa à forma pelo qual o ato foi exteriorizado não está contida nesse conceito. 
12. As relações diretas entre as partes também podem dar origem a direitos processuais adquiridos. Tanto os negócios jurídicos processuais, como nos casos em que as condutas das partes ocasionam danos para a parte adversa verifica-se a formação desses direitos.

13. O último campo de análise para delimitação dos direitos processuais adquiridos refere-se aos institutos bifrontes. A relevância desses institutos para o direito intertemporal diz respeito não só à caracterização de direitos processuais adquiridos, mas aos momentos em que suas aquisições ocorrem. Tratando-se de institutos com ligação muito forte com o direito material, esse momento coincide com o de aquisição do direito material.

14. A análise das regras e princípios do sistema de direito processual permitem concluir que o juiz brasileiro é dotado de amplos poderes de direção do processo, a fim de possibilitar que o instrumento processo seja dotado de eficiência no alcance de seus objetivos.

Aplicando-se essa premissa ao direito processual intertemporal chega-se à conclusão de que o juiz brasileiro pode, em determinados casos, afastar a eficácia imediata da lei processual para assegurar que o processo atinja os seus escopos.

15. A atuação do juiz não poderá ferir direitos adquiridos das partes e deverá ser limitada em função de sua finalidade. O poder do juiz somente poderá ser utilizado quando for ao encontro dos objetivos do sistema.

Esse poder poderá ser exercido de ofício, mas deverá sempre implicar em uma decisão expressa e fundamentada do juiz, a qual, naturalmente, poderá ser impugnada pela parte.

Aconselha-se que sempre que possível o juiz submeta a questão ao contraditório prévio entre as partes e adote maiores cautelas no 
momento de afastar a eficácia imediata de uma lei processual que trate de competência absoluta.

16. A análise da situação jurídica na doutrina objetivista tem importância para compreender o fenômeno da retroatividade da lei. Embora sua noção não tenha sido suficientemente esclarecida, pode-se identificar que se trata de uma relação entre um fato e uma norma. Seu conteúdo é bastante amplo e foi utilizado por ROUBIER para substituir os conceitos de direito adquirido e de relação jurídica.

17. O conceito de situação jurídica processual utilizado na doutrina processual e associado às diferentes posições jurídicas ocupadas pelos sujeitos processuais não é o mesmo utilizado na doutrina do direito processual intertemporal e deve ser descartado para a solução de problemas dessa espécie.

18. A identificação das situações jurídicas processuais deve partir da comparação entre as normas para que se possa isolar o fenômeno a que ela se refere. A ocorrência concreta do fenômeno abstratamente regulado pela norma é que dá origem à situação jurídica processual.

19. Na solução de problemas relativos às situações jurídicas processuais dependentes deve-se entender que, quando uma situação jurídica processual é efeito de outra sua criação não acarreta retroatividade, razão pela qual a lei que a cria deve, em princípio, ter aplicação imediata.

\subsection{Explicações sobre o sistema de direito processual civil intertemporal}

Para concluir, devemos desenhar a linha básica do nosso sistema de direito processual civil intertemporal da seguinte maneira.

Trata-se de sistema com dupla proteção, uma constitucional e de natureza subjetiva e outra objetiva, que impede a aplicação retroativa da lei. 
Não havendo menção expressa sobre a retroatividade, a lei processual detém aplicação imediata, respeitando os direitos adquiridos processuais. Essa eficácia imediata pode ser afastada pelo juiz quando sua utilização em um caso concreto não permitir o alcance dos objetivos da norma, ou ocasionar prejuízos para os escopos do processo. 


\section{XI - Bibliografia}

ABDO, Helena Najjar. O abuso do processo. São Paulo: RT, 2.007.

ALEXY, Robert. Derecho y razón práctica. Fontamara, 1.993.

ALVARO DE OLIVEIRA, Carlos Alberto. Do formalismo no processo civil. $2^{\mathrm{a}}$ edição, São Paulo: Saraiva, 2.003.

ALVES, João Luiz. Código civil da República dos Estados Unidos do Brasil, vol 1. $3^{\text {a }}$ edição, Rio de Janeiro: Borsoi, 1.957.

ALVES, José Carlos Moreira. "Direito subjetivo, pretensão e ação", in Revista de processo $n^{\circ} 47$.

AMARAL, Guilherme Rizzo. Estudos de Direito intertemporal e processo. Porto Alegre: Livraria do Advogado, 2.007.

AMENDOEIRA JÚNIOR, Sidnei. Poderes do juiz e tutela jurisdicional - o aumento dos poderes do juiz como forma de obtenção da tutela jurisdicional efetiva, justa e tempestiva. Dissertação para obtenção do grau de mestre no curso de pósgraduação da Faculdade de Direito da Universidade de São Paulo, 2.002.

AMERICANO, Jorge. Comentários ao Código de Processo Civil do Brasil, vol. 4. São Paulo: Livraria Acadêmica - Saraiva \& cia. Editores, 1.943.

ANDOLINA, Italo e VIGNERA, Giuseppe. II modello costituzionale del processo civile italiano, corso di lezioni. Torino: G. Giappichelli editore, 1.990.

APRIGLIANO, Ricardo de Carvalho. A apelação e seus efeitos. $2^{a}$ edição, São Paulo: Atlas, 2.007.

A ordem pública no direito processual civil. Tese para obtenção do

título de doutor no curso de pós-graduação da Faculdade de Direito da Universidade de São Paulo, 2.009.

ARAGÃO, Moniz de. Comentários ao código de processo civil, vol. II. Rio de Janeiro: Forense, 1.974.

ARRUDA ALVIM, José Manoel. Manual de direito processual civil, vol. I. $8^{a}$ Edição, São Paulo. Revista dos Tribunais, 2.003.

AUBRY, C. e RAU, C.. Cours de droit civil français d'aprés la méthode de zacharie, tome 1er. Paris: Imprimerie et librairie générale de jurisprudence Marchal et Billard, 1.897. 
BALEEIRO, Aliomar. Direito tributário brasileiro. 11ª edição, Rio de Janeiro, 1.999. BARBALHO, João U. C.. Constituição Federal Brasileira - commentarios. $2^{\mathrm{a}}$ ed. (publicação posthuma). Rio de Janeiro: F. Briguiet e cia., editores, 1.924.

BARBOSA MOREIRA, José Carlos. "Efetividade do processo e técnica processual", in Temas de Direito Processual, 6ª série. São Paulo: Saraiva, 1.997. "Coisa julgada e declaração", in Temas de direito processual, primeira série. $2^{\mathrm{a}}$ edição, São Paulo: Saraiva, 1.988.

. "Ainda e sempre a coisa julgada", in revista dos tribunais, ano 59, vol. 416, jun. 1.970 .

. "Duelo e processo", in Revista de Processo, $n^{\circ} 112$, outubrodezembro 2.003.

- Estudos sobre o novo Código de Processo Civil. Rio de Janeiro: LIber juris, 1.974.

. “Considerações sobre a chamada 'relativização' da coisa julgada material", in Temas de direito processual, nona série. São Paulo: Saraiva, 2.007.

. "A função social do processo civil moderno e o papel do juiz e das partes na direção e na instrução do processo", in Temas de direito processual $3^{a}$ série. São Paulo: Saraiva, 1.984.

. O novo processo civil brasileiro. $23^{\mathrm{a}}$ ed., Rio de Janeiro: Forense, 2.005 .

BATALHA, Wilson de Souza Campos. Direito intertemporal. Rio de Janeiro: Forense, 1.980.

. Lei de Introdução ao Código Civil, vol. II, tomo I. São Paulo: Max Limonad, 1.959.

BEDAQUE, José Roberto dos Santos. Direito e processo. $4^{a}$ edição, Brasil: Malheiros, 2.006.

. Efetividade do processo e técnica processual. Brasil: Malheiros,

2.006 .

. Poderes instrutórios do juiz. 2a Edição, São Paulo: Revista dos Tribunais, 1.994.

. Tutela cautelar e tutela antecipada: tutelas sumárias e de urgência (tentativa de sistematização). $3^{a}$ Edição, São Paulo: Malheiros, 2.003.

. Competência e suspeição - julgados e pareceres. São Paulo: RT, 1.995. 
. "Garantia da amplitude de produção probatória", in Garantias constitucionais do processo civil. $1^{\mathrm{a}}$ edição, $2^{\mathrm{a}}$ tiragem, São Paulo: RT, 1.999.

. "Nulidade processual e instrumentalidade do processo", in Revista de processo, $n^{\circ} 60$, outubro-dezembro 1.990.

BEVILÁQUA, Clóvis. Codigo Civil dos Estados Unidos do Brazil comentado, vol. I. São Paulo, Rio de Janeiro e Belo Horizonte: Livraria Francisco Alves, 1.916.

. Teoria geral do direito civil. São Paulo: Livraria Francisco Alves,

1.908.

BONDIOLI, Luís Guilherme Aidar. "Tutela específica: inovações legislativas e questões polêmicas", in A nova etapa da reforma do código de processo civil. São Paulo: Saraiva, 2.002.

BONGIORNO, Girolamo. "Il regime transitorio: un momento critico della riforma del codice di procedura civile", in Rivista trimestrale di diritto processuale civile, anno XLVI, n. 4.

BUENO, Cassio Scarpinella. Curso sistematizado de direito processual civil, vol. 1. São Paulo: Saraiva, 2.007.

A nova etapa da reforma do Código de Processo Civil, volumes 1 a

3. $2^{\mathrm{a}}$ edição, São Paulo: Saraiva, 2.006.

BÜLOW, Oskar von. Teoria das exceções e dos pressupostos processual. Tradução e notas de Ricardo Rodrigues Gama, 2a edição, Campinas: LZN Editora, 2.005.

BUZAID, Alfredo. A ação declaratória no direito brasileiro. São Paulo: Livraria acadêmica - Saraiva \& cia., 1.943.

. Exposição de motivos do projeto de lei de código de processo civil, encaminhada pela Mensagem do Ministério da Justiça $\mathrm{n}^{0}$ 210, de 2.8.72, publicada no Diário do congresso Nacional de 28 de setembro de 1.972, suplemento no 99, pp. 64-72.

CAHALI, Youssef Said. Honorários advocatícios. São Paulo: RT, 1978.

CAIS, Cleide Previtalli. O processo tributário. 6ª Edição, São Paulo: RT, 2.009.

CAIS, Fernando Fontoura da Silva. Preclusão e a instrumentalidade do processo. São Paulo, 2.006. Dissertação para obtenção do grau de mestre no curso de pósgraduação da Faculdade de Direito da Universidade de São Paulo, 2.006. 
CAIS, Frederico Fontoura da Silva. Fraude de execução. São Paulo: Saraiva, 2.005 .

CALAMANDREI, Piero. Institucines de derecho procesal civil segun el nuevo codigo, vol. I, tradução para o espanhol e estudo preliminar da $2^{\mathrm{a}}$ Edição italiana de 1.943 por MELENDO, Santiago Sentís, Buenos Aires: Ediciones Juridicas Europa-America, 1.973.

CANOTILHO, J. J. Gomes e MOREIRA, Vital. Constituição da República Portuguesa anotada. 3a Edição, Coimbra: Coimbra editora, 1.993.

CAPONI, Remo. "Tempus regit processum - un appunto sull'efficacia delle norme processuali nel tempo", in Rivista di diritto processuale, anno $L X I, n$. 2, aprilegiugno 2.006 .

CAPPELLETTI, Mauro. Juízes legisladores?. Reimpressão, Porto Alegre: Sergio Antonio Fabris editor, 1.999. . Juízes irresponsáveis?. Porto Alegre: Sergio Antonio Fabris editor,

1.989.

CARDOZO, José Eduardo Martins. Da retroatividade da lei. São Paulo: RT, 1.995.

CARMONA, Carlos Alberto. Arbitragem e processo. 2a edição, São Paulo: Atlas, 2.004 .

CARNELUTTI, Francesco. Sistema de direito processual civil, vol. 1. $1^{\mathrm{a}}$ edição, São Paulo: Classic Book, 2.000.

. Teoría general del derecho. Tradução para o espanhol de POSADA,

Carlos G., Madrid: Editorial revista de derecho privado, 1.941.

CASSARINO, Sebastiano. Le situazioni giuridiche e l'oggetto della giurisdizione amministrativa. Milano: Giuffrè, 1.955.

CASTRO, Araujo. A nova Constituição Brasileira. Rio de Janeiro: Livraria Editora Freitas Bastos, 1.935.

CASTRO FILHO, José Olympio de. Comentários ao Código de Processo Civil, vol X. $2^{\mathrm{a}}$ edição, Rio de Janeiro: Forense, 1980.

CHASSAT, Mailher de. Traitè de l'interpretation des lois. Nouvelle edition, Paris: Chez A. Durand, Librarie, 1.845.

CHINA, Sérgio la. Manuale di diritto processuala civile, vol. 1. Milano: Giuffrè, 2.003 . 
CHIOVENDA, Giuseppe. Instituições de direito processual civil, vol 1, tradução de MENEGALE, J. Guimarães, com notas de LIEBMAN, Enrico Tullio. $3^{a}$ Edição, São Paulo: Saraiva, 1.969.

"Cosa giudicata e preclusione" in Rivista italiana per le scienze giuridiche, fascicolo I. Roma: Società Editrice Foro italiano, 1.933.

. "Cosa giudicata e competenza", in Saggi di Diritto Processuale Civile, vol 2. Roma, Società Editrice Foro Italiano, 1.931.

- Principii di diritto processuale civile. Ristampa della $3^{a}$ edição, Napoli: Casa editrice dott. Eugenio Jovene, 1.980.

- "La natura processuale delle norme sulla prova e l'efficacia delle legge processuale nel tempo", in. Saggi di Diritto Processuale Civile, vol. I. Roma: Società Editrice Foro Italiano, 1.930.

CHIRONI. Istituzioni di diritto civile italiano. vol I. $2^{\mathrm{a}}$ Edição, Milano, Torino, Roma: Fratelli Bocca editori, 1.912.

CHIRONI, G. P. e ABELLO, L.. Trattato di diritto civile italiano, vol. I. Torino: Fratelli Bocca editori, 1.904.

CIANCI, Mirna. "Direito intertemporal e a Lei 11.232". Artigo publicado na página do Migalhas (www.migalhas.com.br) de 27 de março de 2.007.

COLIN, A. e CAPITANT, H.. Traité de droit civil, tome 1er. Paris: Dalloz, 1.952.

COMOGLIO, Luigi Paolo. “Garanzie costituzionali e 'giusto processo' (modelli a confronto)", in Revista de processo, $n^{\circ} 90$.

CORRADO-FERRI-TARUFFO, Lezioni sul processo civile. $2^{\mathrm{a}}$ edição, Bologna: Società editrice il Mulino, 1.998.

CORREIA, Marcus Orione Gonçalves. Teoria geral do processo. $5^{a}$ edição, São Paulo: Saraiva, 2.009.

COSTA, Alfredo de Araújo Lopes da. Direito processual civil brasileiro, vol. I. $2^{\mathrm{a}}$ ed., Forense: Rio de Janeiro, 1.959.

COSTA, Susana Henriques da. Condições da ação. São Paulo: Quariter latin, 2.005 .

COUTURE, Eduardo. Fudamentos del derecho procesal civil. $3^{a}$ edição póstuma, reimpressão inalterada, Buenos Aires: Depalma, 1.990.

Introducción al estudio del proceso civil. $2^{\mathrm{a}}$ edición, reimpresión,

Buenos Aires: Depalma, 1.988. 
COVIELLO, Nicola. Manuale di diritto civile italiano, parte generale. 2a Edição, Milano: Società Editrice Libraria, 1.915.

CRUZ E TUCCI, José Rogério. Lineamentos da nova reforma do CPC. São Paulo: Revista dos Tribunais, 2.002.

. Limites subjetivos da eficácia da sentença e da coisa julgada civil.

São Paulo: RT, 2006.

DE PLÁCIDO E SILVA, Oscar José. Vocabulário jurídico, vol. II, D - I. 2 2a edição, Rio de Janeiro: Forense, 1.967.

DEMOLOMBE, C. Cours de code de Napoleon, vol. I. Paris: Imprimerie Générale, A. Lahure Éditeur, 1.880.

Dicionário jurídico da Academia Brasileira de Letras Jurídicas. 8a edição, Rio de Janeiro: Forense, 2.003.

DINAMARCO, Cândido Rangel. Instituições de direito processual civil, vol. I. Brasil: Malheiros, 2.001.

. Instituições de direito processual civil, vol. II. Brasil: Malheiros,

2.001.

. A reforma do Código de Processo Civil. $3^{a}$ Edição, Brasil: Malheiros, 1.996.

. A instrumentalidade do processo. $8^{a}$ edição, Brasil: Malheiros, 2.000 .

. A reforma da Reforma. 5a edição, Brasil: Malheiros, 2.003.

. Fundamentos do direito processual civil moderno, tomo I. $3^{\mathrm{a}}$ edição,

Brasil: Malheiros, 2.000.

. anotações ao Manual de direito processual civil, vol. I, de Enrico Tullio Liebman. Rio de Janeiro: Forense, 1.984.

. "Relativizar a coisa julgada material", in Nova Era do Processo Civil. São Paulo: Malheiros, 2.003.

. "Tempestividade dos recursos", in Revista dialética de direito processual, $n^{\circ} 16$.

DINAMARCO, Pedro da Silva. Ônus processuais: limites à aplicação das conseqüências previstas para o seu não-cumprimento. Tese para obtenção do título de doutor no curso de pós-graduação da Faculdade de Direito da Universidade de São Paulo, 2.007. 
DOUAI, Merlin de. "Effet rétroactif", in Répertoire universel et raisonné de jurisprudence, tome cinquième. $5^{\mathrm{a}}$ Edição, Paris: Garnery, Librarie, 1.827.

DUGUIT, Léon. Traitè de droit constitutionel, I. 13édition, Paris: Ancienne Librairie Fontemoing \& cie. éditeurs, 1.927.

- Traitè de droit constitutionel, II. 13 ${ }^{\mathrm{e}}$. Édition, Paris: Ancienne Librairie Fontemoing \& cie. éditeurs, 1.928.

- Traité de droit constitutionnel, tome $1^{e r}$. $3^{\mathrm{a}}$ ed., Paris: Ancienne librairie fonteming \& cie., éditeurs, 1.927.

ENNECCERUS, Ludwig. Tratado de derecho civil, tomo I, vol. I. Tradução da 39a edição alemã para o espanhol por GONZÁLES, Blas Pérez e ALGUER, José, Barcelona: Bosch - casa editorial, 1.934.

ESPÍNOLA, Eduardo e ESPÍNOLA FILHO, Eduardo. Da lei, da sua obrigatoriedade, do direito intertemporal. São Paulo: Freitas Bastos, 1.939.

FARIA, Bento de. Aplicação e retroatividade da lei. Rio de Janeiro: A. Coelho Branco Filho editor, 1.934.

FAZZALARI, Elio. "Efficacia della legge processuale nel tempo", in Rivista trimestrale di diritto e procedura civile, anno XLIII, n. 4. . Note in tema di diritto e processo. Milano: Giuffrè, 1.957.

FERRARA, Francesco. Trattato di diritto civile italiano. vol. I. Roma:athenaeum, 1.921.

FERREIRA FILHO, Manoel Caetano. A preclusão no direito processual civil. Curitiba: Juruá Editora, 1.991.

FRANÇA, Rubens Limongi. A irretroatividade das leis e o direito adquirido. $5^{a}$ edição, São Paulo: Saraiva, 1.998. . Jurisprudência da irretroatividade e do direito adquirido. São Paulo: RT, 1.982.

. Direito intertemporal brasileiro - doutrina da irretroatividade das leis e do direito adquirrdo. 2a Edição, São Paulo: RT, 1.968.

FREIRE, Rodrigo Cunha Lima. Condições da ação - enfoque sobre o interesse de agir no processo civil brasileiro. São Paulo: RT, 2.000.

FREITAS, Paulo de. Direito processual subjetivo. São Paulo: Saraiva, 1.953. 
GABBA, Carlo Francesco. Teoria della retroattività delle leggi, vol. 1. 2a Ed., Torino: UTET, 1.884

. Teoria della retroattività delle leggi, vol. 2. $2^{\mathrm{a}}$ Ed., Torino: UTET,

1.884

. Teoria della retroattività delle leggi, vol. 4. $2^{\mathrm{a}}$ Ed., Torino: UTET,

1.884

GAJARDONI, Fernando da Fonseca. Flexibilidade procedimental (um novo enfoque para o estudo do procedimento em matéria processual). Tese para obtenção do título de doutor no curso de pós-graduação da Faculdade de Direito da Universidade de São Paulo, 2.007.

GAMBARO, Antonio e SACCO, Rodolfo. Sistemi giuridici comparati. Ristampa, Torino: UTET, 1.998.

GARCIA, Basileu. Instituições de direito penal, vol. I, tomo I. $5^{\text {a }}$ edição, São Paulo: Editora Max Limonad, 1.980.

GARRIDO DE PAULA, Paulo Afonso. Código de processo civil interpretado. São Paulo: Atlas, 2.004.

GIANNICO, Maricí. A prova no Código Civil - natureza jurídica. São Paulo: Saraiva, 2005.

GIANNICO, Maurício. A preclusão no direito processual civil. São Paulo: Saraiva, 2.005 .

As novas reformas do CPC e de outras normas processuais. Obra escrita em parceria com outros autores, São Paulo: Saraiva, 2.009.

GOLDSCHMIDT, James. Princípios gerais do processo civil. Belo Horizonte: Editora Líder, 2.002.

. Direito processual civil. Traduzido e anotado por Ricardo Rodrigues Gama. Curitiba, Juruá, 2.002.

. Problemas jurídicos y políticos del proceso penal Barcelona: Bosch -

Casa editorial, 1.935.

GRAU, Eros Roberto. Ensaio e discurso sobre a interpretação/aplicação do direito. $2^{\mathrm{a}}$ Edição, São Paulo: Malheiros, 2.003.

GRINOVER, Ada Pellegrini. As garantias constitucionais do direito de ação. Dissertação para concurso à livre docência de Direito Judiciário Civil na Faculdade de Direito da Universidade de São Paulo, 1.972. 
GRINOVER, Ada Pelegrini, CINTRA, Antônio Carlos e Araújo e DINAMARCO, Cândido Rangel. Teoria geral do processo. 18ª Edição, São Paulo: Malheiros, 2.002 .

GRINOVER, Ada Pellegrini, SCARANCE FERNANDES, Antonio, MAGALHÃES, GOMES FILHO, Antonio. As nulidades no processo penal. $7^{\text {a }}$ edição, São Paulo: RT, 2.001.

GUILLIEN, Raymond et VINCENT, Jean. Lexique des termes juridiques. $13^{\mathrm{e}}$. éd., Paris : Dalloz, 2.001.

JEVEAUX, Geovany. "Direito adquirido processual", in Revista de processo, $n^{\circ} 36$. JOSSERAND, Louis. Cours de droit civil positif français, vol. I. Paris: Librarie du recueil sirey, 1.938 .

JULIOTTI, Pedro de Jesus. Direito intertemporal processual penal. São Paulo: Editora Juarez de Oliveira, 2.007.

KOMATSU, Roque. Da invalidade no processo civil. São Paulo: RT, 1.991.

LACERDA, Galeno. O novo direito processual civil e os feitos pendentes. $2^{\mathrm{a}}$ edição, Rio de Janeiro: Forense, 2.006. . "O Código e o formalismo processual", in Ajuris, 28 de julho de 1.993. . Teoria geral do processo. Rio de Janeiro: Forense, 2.006.

LACERDA, Paulo. Manual do Código Civil Brasileiro, vol. I, parte 1á. Rio de Janeiro: Editor Jacintho Ribeiro dos Santos, 1.918.

LARENZ, Karl. Metodologia da ciência do direito. Tradução de LAMEGO, José, $3^{a}$ Edição, Lisboa: Fundação Calouste Gulbenkian, 1.997.

LASSALE, Ferdinand. Théorie Systematique des Droits Acquis. Paris: v. Giard \& E. Brière, 1.904.

LAURENT, Supplemento al diritto civile, vol. 1. Milano: Società editrice libraria, 1.903.

. Principes de droit civil français, vol. I. $3^{\mathrm{a}}$ ed., Bruxelles: BruyllantChristophe \& cie. Éditeurs, 1.878. 
LIEBMAN, Enrico Tullio. Eficácia e autoridade da sentença e outros estudos sobre a coisa julgada. Tradução de BUZAID, Alfredo e AIRES, Benvindo, 4ª edição, Rio de Janeiro: Forense, 2.006.

. "L'azione nella teoria del processo civile", in Problemi di processo civile. Milano: Morano, 1.967.

Manual de direito processual civil, vol. I. Tradução e notas da $4^{a}$ edição italiana de 1.980 por DINAMARCO, Cândido Rangel, Rio de Janeiro: Forense, 1.984.

LIMA, Alcides de Mendonça. Introdução aos recursos cíveis. 2a edição, São Paulo: RT, 1.976.

LIMA, Lucas Rister de Sousa. Direito intertemporal no processo civil - as normas e situações processuais com natureza de direito material. Rio de Janeiro: Elsevier, 2.009.

LOMONACO, Giovanni. Istituzione di Diritto Civile Italiano, vol. I. $2^{\mathrm{a}}$ Edizione, Napoli: Presso Nicola Jovene \& Co. Librai-Editori, 1.894.

LOPES, Bruno Vasconcelos de Carrilho. Honorários advocatícios no processo civil. São Paulo: Saraiva, 2.008.

LOPES, João Batista. Curso de direito processual civil, vol. I. São Paulo: Atlas, 2.005 .

MACHADO, Antônio Cláudio da Costa. Código de Processo Civil interpretado artigo por artigo, parágrafo por parágrafo. 2a Edição, São Paulo: Saraiva, 1.996.

MACHADO, Marcelo Pacheco. Incerteza e processo: um estudo direcionado às técnicas recursais e à ação rescisória. Dissertação para obtenção do grau de mestre no curso de pós-graduação da Faculdade de Direito da Universidade de São Paulo, 2.008.

MARINONI, Luiz Guilherme e ARENHART, Sérgio Cruz. Manual do processo de conhecimento. 4ª Edição, São Paulo:RT, 2.005.

MARQUES, José Frederico. Manual de direito processual civil, vol. 1. 13a edição, São Paulo: Saraiva, 1.990.

Instituições de Direito Processual Civil, vol. II. $1^{\text {a }}$ Edição revista, atualizada e completada por Ovídio Rocha Barros Sandoval, Campinas: Millennium, 2.000. 
MAXIMILIANO, Carlos. Hermenêutica e aplicação do direito. 19a edição, Rio de Janeiro: Forense, 2.006.

. Direito intertemporal ou teoria da retroatividade das leis. $2^{\mathrm{a}}$ edição, São Paulo: Freitas Bastos, 1.955.

- Commentarios Constituição Brasileira. Rio de Janeiro: Jacintho Ribeiro dos Santos editor, 1.918.

MAZZEI, Rodrigo. Reforma do CPC. São Paulo: RT, 2.006.

MENDONÇA, Maria Luiza Vianna Pessoa de. O princípio constitucional da irretroatividade da lei. Belo Horizonte: Del Rey, 1.996.

MIRANDA, Vicente. Poderes do juiz no processo civil brasileiro. São Paulo: Saraiva, 1.992.

MONTEIRO, João. Theoria do processo civil, volumes I, II e III. $5^{\text {a }}$ edição, São Paulo: Typographia academica, 1.936.

MONTEIRO, Washington de Barros. Curso de direito civil, vol 1. $28^{a}$ edição, São Paulo: Saraiva, 1987-1989.

MONTESANO, Luigi. "La garanzia costituzionale del contradditorio", in Rivista di diritto processuale, anno $L V, n^{\circ} 4$.

NEGRÃO, Theotonio, GOUVÊA, José Roberto Ferreira e BONDIOLI, Luís Guilherme Aidar. Código de Processo Civil e legislação processual em vigor. $41^{\mathrm{a}}$ Edição, São Paulo: Saraiva, 2.009.

NEVES, Daniel Amorim Assumpção. Preclusão pro judicato e preclusão judicial no processo civil brasileiro. Dissertação para obtenção do grau de mestre no curso de pós-graduação da Faculdade de Direito da Universidade de São Paulo, 2.002 .

. Reforma do CPC. São Paulo: RT, 2.006.

OLIVEIRA, Bruno Silveira de. O juízo de identificação de demandas e de recursos no processo civil brasileiro (contribuição ao estudo dos atos postulatórios), Tese para obtenção do título de doutor no curso de pós-graduação da Faculdade de Direito da Universidade de São Paulo, 2.009.

. "Um novo conceito de sentença?", in Revista de Processo no 149.

. Conexidade e efetividade processual. São Paulo: RT, 2.008. 
PACE, Gaetano. Il diritto transitorio con particolare riguardo al diritto privato. Milano: Casa Editrice Ambrosiana.

PARENTE, Eduardo de Albuquerque. "Jurisdição e poder", in Os poderes do juiz e o controle das decisões judiciais - estudos em homenagem à Professora Teresa Arruda Alvim Wambier. São Paulo: RT, 2.008.

PASSOS, J. J. Calmon de. "O magistrado, protagonista do processo judicial?" in Os poderes do juiz e o controle das decisões judiciais - estudos em homenagem à Professora Teresa Arruda Alvim Wambier. São Paulo: RT, 2.008.

PEREIRA, Caio Mário da Silva. Instituições de direito civil, vol. I. 20a edição, Rio de Janeiro: Forense, 2.004.

PESSOA, Fábio Guidi Tabosa. Elementos para uma teoria do direito intertemporal no processo civil. Tese para obtenção do título de doutor no curso de pósgraduação da Faculdade de Direito da Universidade de São Paulo, 2.004. . Código de processo civil interpretado. São Paulo: Atlas, 2.004.

PICARDI, Nicola. "Il principio del contraditorio", in Rivista di diritto processuale, anno LIII, seconda serie, $n$. 3, Luglio-Settembre 1.998.

PIMENTEL, Wellington Moreira. "Questões de direito intertemporal diante do Código de Processo Civil", in Revista forense, ano 71, vol. 251, jul./ago. 1.975.

. A aplicação do novo código de processo civil às causas pendentes.

Rio de Janeiro: CEJUR, 1.974.

PINTO, Tereza Arruda Alvim. Repertório de jurisprudência e doutrina sobre nulidades processuais, $2^{a}$ série. São Paulo: RT, 1.992.

. O direito processual de estar em juízo. São Paulo: RT, 1.996.

PLANIOL, Marcel. Traité élémentaire de droit civil, tome 1er, n. 243. 4e. ed., Paris : Librairie générale de droit et de jurisprudence, 1.948.

PONTES DE MIRANDA, Francisco Cavalcanti. Comentários à Constituição de 1.946. tomo IV. $3^{\mathrm{a}}$ Edição, Rio de Janeiro: Editor Borsoi, 1.960.

, Comentários ao Código de Processo Civil, tomo XVIII. Rio de Janeiro: Forense, 1.978.

PORCHAT, Reynaldo. Da retroactividade das leis civis. São Paulo: Duprat \& Cia. 1.909.

PORTANOVA, Rui. Princípios do processo civil. $3^{a}$ edição, Porto Alegre: Livraria do Advogado, 1.999.

PORTO, Sérgio Gilberto. Coisa julgada civil. $3^{a}$ Edição, São Paulo: RT, 2.006. 
PUOLI, José Carlos Baptista. Os poderes do juiz e as reformas da lei processual civil brasileira. São Paulo: Editora Juarez de Oliveira, 2.001.

RÁO, Vicente. O direito e a vida dos direitos, vol. I, tomo II. São Paulo: Max Limonad, 1960.

REALE, Miguel. Filosofia do direito. 14ª edição, São Paulo: Saraiva, 1.991.

RESENDE DE BARROS, Sérgio. Contribuição dialética para o constitucionalismo. Campinas: Millennium, 2.007.

RODRIGUES, Marcelo Abelha. A terceira etapa da reforma processual civil. obra escrita em parceria com CHEIM JORGE, Flávio e DIDIER JR., Freddie. São Paulo: Saraiva, 2006.

RODRIGUES, José Carlos. Constitutição Política do Império do Brasil seguida do Acto Addicional, da Lei da sua interpretação e de outras analysada por um jurisconsulto e novamente annotada com as leis regulamentares, decretos, avisos, ordens, e portarias que Ihe são relativas. Rio de Janeiro: Casa dos Editores Eduardo \& Henrique Laemmert, 1.863.

ROSAS, Roberto. "Direito intertemporal processual", in Revista dos tribunais, ano 71, vol. 559, maio de 1.982.

ROUBIER, Paul. Les conflits des lois dans le temps (théorie dite de la nonrétroactivité des lois), tome $1^{\text {er }}$. Paris : Librairie du Recueil Sirey : 1.929. . Le droit transitoire. $2^{\mathrm{a}}$ edition, Paris: Dalloz et Sirey, 1.960. . Droits subjectifs et situations juridiques. Paris : Dalloz, 1.963.

RUGGIERO, Roberto de. Instituições de Direito Civil, vol. I. $1^{\text {a }}$ edição, Campinas: Bookseller, 1.999.

SANTOS, Ernane Fidélis dos. As reformas de 2005 do Código de Processo Civil. São Paulo: Saraiva, 2.006.

. Manual de direito processual civil, vol. I. $7^{\text {a }}$ Edição, São Paulo: Saraiva, 1.999.

SANTOS, J. M. de Carvalho. Codigo civil brasileiro interpretado principalmente sobre o ponto de vista pratico. Rio de Janeiro: Borsoi \& cia., 1.934.

SANTOS, Moacyr Amaral. Primeiras linhas de direito processual civil, vol 1. São Paulo: Saraiva, 1989-1990. 
SANTOS, Nelton dos. Código de Processo Civil Interpretado. São Paulo: Atlas, 2.004 .

SATTA, Salvatore. Diritto processuale civile. 9a edição, Padova: Cedam, 1.981.

SAVATIER, René. Cours de droits civil, tome premier. $12^{\mathrm{e}}$. Édition, Paris: Librairie générale de droit et de jurisprudence R. Pichon et R. Durand-Auzias, 1.947.

SAVIGNY, Friedich Carl von. Traité du droit romain modernisé, vol VIII. $2^{\mathrm{a}}$ edition, Paris: Librairie de Firmin Didot Frères, Fils etb cie, 1.860.

. Sistema do direito romano atual, vol.VIII. Tradução de MIORANZA, Ciro. ljuí: Unijuí, 2.004.

SERPA LOPES, Miguel Maria de. Comentário teórico e prático da Lei de Introdução ao Código Civil, vol. I. Rio de Janeiro: Livraria Jacintho Editora, 1.943.

SICA, Heitor Vitor Mendonça. Preclusão processual civil. São Paulo: Editora Atlas, 2.006 .

- "Algumas implicações do novo conceito de sentença no processo civil, de acordo com a lei no 11.232/2005", in Reflexões sobre a reforma do Código de Processo Civil. Estudos em homenagem a Ada Pellegrini Grinover, Cândido Rangel Dinamarco e Kazuo Watanabe, organizador CARMONA, Carlos Alberto. São Paulo: Atlas, 2.007.

SIDOU, J.M. Othon. O direito legal: história, interpretação, retroatividade e elaboração das leis. Rio de Janeiro: Forense, 1.985.

SILVA, José Afonso da. "Reforma Constitucional e direito adquirido", in revista de direito administrativo, 213. jul./set. 1.998.

- "Constituição e segurança jurídica", in Constituição e segurança jurídica - direito adquirido, ato jurídico perfeito e coisa julgada - estudos em homenagem a José Paulo Sepúlveda Pertence. $2^{a}$ edição, Belo Horizonte: Fórum, 2.005 .

SILVA, Ovídio A. Baptista da, e GOMES, Fábio. Teoria geral do processo civil. $3^{\mathrm{a}}$ edição, São Paulo: RT, 2.002.

TALAMINI, Eduardo. A coisa julgada e sua revisão. São Paulo: RT, 2.005.

TEIXEIRA, Guilherme Silveira. Ampliação dos poderes do juiz nas recentes reformas processuais e a necessidade de equilíbrio entre segurança e efetividade do processo. Tese para obtenção do título de doutor no curso de pós-graduação da Faculdade de Direito da Universidade de São Paulo, 2.006. 
TEIXEIRA, Sálvio de Figueiredo. Código de Processo Civil Anotado. $7^{a}$ edição, São Paulo: Saraiva, 2.003.

TENÓRIO, Oscar. Lei de Introdução ao Codigo Civil Brasileiro comentada. Rio de Janeiro: Livraria Jacinto Editora, 1.944

THEODORO JÚNIOR, Humberto. As Novas Reformas do Código de Processo Civil. Rio de Janeiro: Forense, 2.007.

. Curso de direito processual civil, vol. I. $41^{\mathrm{a}}$ ed., Rio de Janeiro: Forense, 2.004.

- Lições de direito processual civil. Uberaba: Editora Rio Grande, 1.975.

. "Abuso de direito processual no ordenamento jurídico brasileiro". in Abuso dos direitos processuais, coordenação José Carlos Barbosa Moreira. Rio de Janeiro: Forense, 2.000.

TOBENÃS, José Castan. Situaciones juridicas subjetivas. Madrid: Instituto editorial reus, 1.963.

TUCCI, Rogério Lauria. Direito intertemporal e a nova codificação processual penal (subsídios para sistematização e aplicação do direito transitório no processo penal brasileiro). São Paulo: Bushatsky, 1.975.

. Enciclopédia Saraiva de Direito, vol. 46. São Paulo: Saraiva, 1.977. . Da ação e do processo civil na teoria e na prática. São Paulo: Forense, 1.985.

VALLADÃO, Haroldo. Lei Geral de Aplicação das Normas Jurídicas. Rio de Janeiro, 1.964.

VALLE, Francesco la. "Sucessione di Leggi", in Novissimo digesto italiano, vol. XVIII. Torino: Utet.

VAREILLES-SOMMIÈRES. "Une théorie nouvelle sur la rétroativité des lois", in Révue critique de législation et jurisprudence,1.893.

VARELA, Casimiro. Fundamentos constitucionales del derecho procesal. Buenos Aires: Ad-hoc, 1.999.

VÉSCOVI, Enrique. Introduccion al derecho. 6ª ed., São Paulo: LAEL, 1.971. . Teoría general del proceso. $2^{\mathrm{a}}$ ed., Bogotá: Temis, 1.999.

VICENZI, Brunela Vieira de. A boa-fé no processo civil. São Paulo: Atlas, 2.003. 
WAMBIER, Teresa Arruda Alvim. "Anotações sobre o direito intertemporal e as mais recentes alterações do CPC", in Revista de processo $n^{\circ} 150$.

WAMBIER, Teresa Arruda Alvim, WAMBIER, Luiz Rodrigues e MEDINA, José Miguel Garcia. Breves comentários à nova sistemática processual civil, 2. São Paulo: RT, 2.006.

WAMBIER, Teresa Arruda Alvim e MEDINA, José Miguel Garcia. O dogma da coisa julgada - hipóteses de relativização. que isso sequer seria preciso, porque a coisa julgada é "umbilicalmente ligada ao Estado Democrático de Direito" . São Paulo: RT, 2.003.

WATANABE, Kazuo. "Acesso à Justiça e sociedade moderna", in Participação e processo. São Paulo: RT, 1.988.

YARSHELL, Flávio Luiz. Tutela jurisdiconal. São Paulo: Atlas, 1.999. - Ação rescisória - juízos rescidente e rescisório. São Paulo: Malheiros, 2.005.

ZANZUCCHI, Marco Tullio. Diritto processuale civile, vol. I. $6^{\mathrm{a}}$ ed., Milano: Giuffrè, 1.964.

ZAVASCKI, Teori Albino. Comentários ao Código de Processo Civil, vol. 8. São Paulo: RT, 2.000.

ZVEITER, Waldemar. "O controle do Poder Judiciário". in O Judiciário e a Constituição. Coord. TEIXEIRA, Sálvio de Figueiredo, São Paulo: Saraiva, 1.994. 


\section{Resumo}

O direito intertemporal é um dos ramos mais complexos da ciência jurídica. Não bastasse a amplitude do tema e sua ligação com todos os ramos da ciência jurídica, as soluções apresentadas pela doutrina para seus problemas são bastante variadas e partem de enfoques bem diferenciados na observação dos seus fenômenos.

A despeito de ser uma matéria extremamente importante, porque vinculada com o progresso da ciência jurídica e com a evolução do ordenamento mediante a alteração das leis, ela não recebeu a atenção adequada da doutrina processual, o que reflete na absoluta ausência de parâmetros seguros para o direito intertemporal processual.

Este estudo é uma tentativa de sistematização desse ramo do direito. Para alcançar os objetivos propostos partiu-se da análise das principais doutrinas do direito intertemporal, com atenção especial às de GABBA e ROUBIER por serem elas as que exercem maior influência no nosso sistema. A preocupação principal nesse momento foi a de fixar conceitos que são imprescindíveis para uma boa compreensão do modo como o direito intertemporal é tratado em nosso ordenamento.

Posteriormente foi estudado o sistema de direito intertemporal brasileiro, numa análise global, sem uma preocupação especial, ainda, com o direito processual. A abordagem partiu de uma evolução histórica do tratamento da disciplina e culminou com o esboço do modo como nosso sistema confere proteção aos direitos adquiridos e às situações jurídicas consolidadas contra alterações legislativas.

Fixadas essas idéias, passou-se à análise do direito processual civil intertemporal. Em um primeiro momento foram demonstrados os motivos que justificam uma abordagem da disciplina a partir de um enfoque 
eminentemente processual, para, posteriormente, traçar um resumo da forma como essa disciplina é tratada pela legislação, doutrina e jurisprudência. Dessa análise ressaltaram as principais lacunas da disciplina, que são: a ausência de delimitação dos direitos processuais adquiridos; a falta de sistematização da disciplina dos poderes do juiz em matéria de direito intertemporal e a inexistência de parâmetros seguros para identificação das situações jurídicas processuais.

Identificadas essas lacunas, foram desenvolvidos esforços para que este estudo fornecesse subsídios para preenchê-las. Para tanto, foram estudados isoladamente cada um desses temas e, dentro das limitações do trabalho, buscou-se enfocá-los de maneira diferenciada e mais aproximada, a fim de alcançar os objetivos propostos.

No tópico final foram esclarecidas as principais conclusões obtidas durante o estudo com o desenho do modo como, a partir delas, entendeuse possível sistematizar o direito processual civil intertemporal brasileiro.

Título: Direito processual civil intertemporal

Palavras-chave: direito intertemporal — direito adquirido — irretroatividade da lei - direito processual subjetivo - situação jurídica - poderes do juiz efetividade do processo - garantias processuais 


\begin{abstract}
Intertemporal Law is one of the most intricate branches in the field of legal theory. Adding to its width and to its connection with all juridical fields, the solutions presented by this doctrine are quite ample and stem from diverse focuses when observing its phenomena.

Notwithstanding being an extremely important subject, for it binds upon the progress of the legal science and upon the evolution of Law amendment ordinance, it has not been closely observed by the procedural doctrine, what explains the lack of safe parameters for the procedural intertemporal Law.
\end{abstract}

This paper seeks to systemize this branch of Law. To attain the objectives herein, analysis of the main doctrines of intertemporal law were carried out, and special attention was placed on those of GABBA and ROUBIER for they are the ones that mostly influence our system. The initial worry was to fix concepts which are imperative for understanding how intertemporal law is dealt with in our system.

Afterwards, the intertemporal Brazilian system was examined, on its whole, still not aiming at its procedural aspects. Its address arouse from a historical approach of this discipline and ended up with a draft of how our system confers protection to acquired rights and to consolidated legal cases against legislative alterations.

Thereafter, analysis of intertemporal civil procedure took place. Prima facie, motives which justify its eminent procedural approach was demonstrated and, then, a summary of how it is treated by our legislation, doctrine and jurisprudence. From this analysis its main gaps came to surface, namely: absence of acquired procedural rights delimitation; absence of systematization of judges' authorities inherent in intertemporal law and absence of safe parameters for identification of procedural situations. 
These gaps identified, efforts were endeavored towards this study with a view to providing solutions to them. So, each one was separately studied and, within the scope of this paper, differentiated and closer focuses were sought, aiming at complying with the proposed objectives.

Last, this study's main conclusions are made clearer, with a framework, as of these conclusions, of how it was possible to systemize the Brazilian intertemporal civil law.

Title: Intertemporal civil procedure law

Key words: intertemporal Law - acquired right - irretroactivity of law - subjective procedure law - legal situation - judge authority - enforceability - procedural guarantees 


\section{RIASSUNTO}

Il diritto intemporale è uno dei rami più complessi della scienza giuridica. Non fosse sufficente l'ampiezza del tema ed il suo collegamento con tutti i rami della scienza giuridica, le soluzioni presentate dalla dottrina ai suoi problemi sono abbastanza variati e partono da visioni piuttosto diferenziati nell'osservazione dei suoi fenomeni.

Malgrado sia una materia sumamente importante, poiché vincolata al progresso della scienza giuridica e alla evoluzione dell'ordinamento attraverso l'alterazione delle leggi, essa non ha ricevuto l'attenzione adeguata dalla dottrina processuale, il che riflette nell'assoluta assenza di parametri sicuri al diritto intemporale processuale.

Questo studio è una tentativa di sistematizzazione di questo ramo del diritto. Per raggiungere gli obbiettivi proposti si è partiti dall'analisi delle principali dottrine del diritto intemporale, con attenzione speciale alle di GABBA e ROUBIER per essere loro le che esercitano maggior influenza nel nostro sistema. La preoccupazione principale in questo momento è stata quella di fissare concetti che sono imprescindibili ad una buona comprensione del modo come il diritto intemporale è trattato nel nostro ordinamento.

In seguito è stato studiato il sistema di diritto intemporale brasiliano, in una analisi globale, senza una preoccupazione speciale, ancora, con il diritto processuale. L'approccio è partito da un'evoluzione storica del trattamento della disciplina ed è culminato con la bozza del modo di come il nostro sistema conferisce protezione ai diritti acquisiti e alle situazioni giuridiche consolidate contro alterazioni legislative.

Una volta fissate queste idee,si è passato all'analisi del diritto processuale civile intempotale. In un primo momento sono stati dimostrati i motivi che giustificano un approccio della disciplina partendo di una visione eminentemente processuale, per, posteriormente, tracciare un riassunto della 
forma come questa disciplina è trattata dalla legislazione, dottrina e giurisprudenza.Di questa analisisi si sono rilevate le principali lacune della disciplina, che sono:la mancanza di delimitazione dei diritti processuali acquisiti; l'assenza di sistematizzazione della disciplina dei poteri del giudice in materia di diritto intemporale e l'inesistenza di parametri sicuri per l'identificazione delle situazioni giuridiche processuali.

Identificate queste lacune, sono stati sviluppati sforzi affinché questo studio fornisse sussidi per colmarle. Pee tanto, sono stari studiai isolatamente ognuno di questi temi e, dentro delle limitazioni del lavoro, si è cercato di mirarli di modo differenziato e più aprossimato, con la finalità di raggiungere gli obbiettivi proposti.

Nel punto finale sono state chiarite le principali conclusioni ottenute durante lo studio con il disegno del modo come, partendo da loro, è stato possibile sistematizzare il diritto processuale civile intemporale brasiliano.

Titolo: Diritto processuale civile intemporale Parole Chiavi: diritto intemporale - diritto acquisito - irretroattività della legge -diritto processuale soggettivo - situazione giuridica - poteri del giudice - effetività del processo - garanzie processuali. 